

This book is DUE on last date stamped below

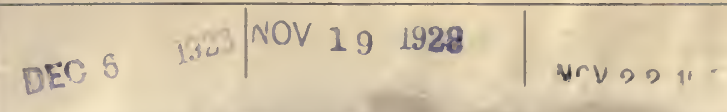

$\Delta$

N

SOL'THERN BRANCH,

- UNIVERSTTY OF CALIFORIVIA,

WBRARY,

LOS ANGELLS, SALJR. 





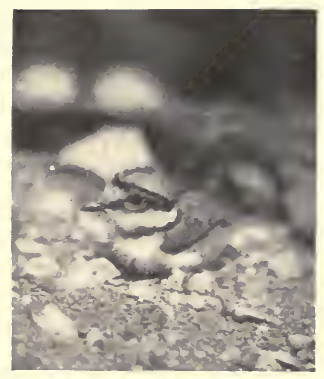

i

$6^{3}$ 



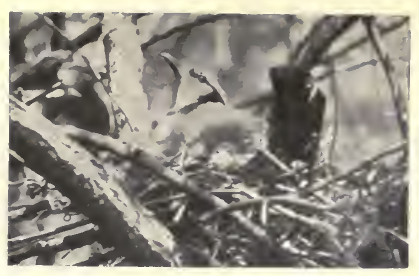

\section{FRIENDS IN FEATHERS}


"The kernels of nuts and the resins of trees, The nectar distilled by the wild honey-bees, Should be thrown in together, to flavor my words With the zest of the woods and the joy of the birds!"

-Thompson 



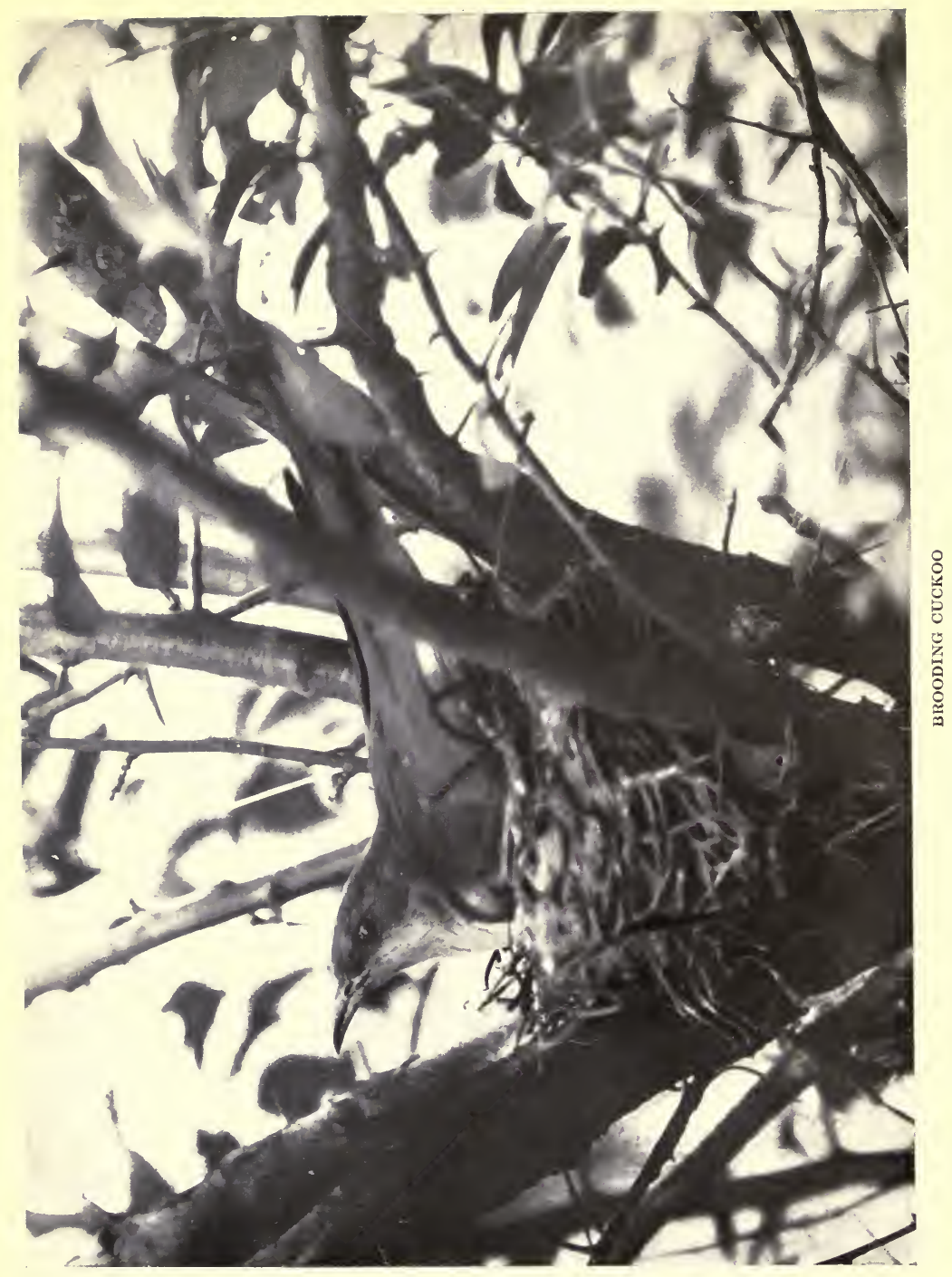




\section{FRIENDS IN FEATHERS}

CHARACTER STUDIES OF NATIVE AMERICAN BIRDS WHICH, THROUGH FRIENDLY ADVANCES, I INDUCED TO POSE FOR ME, OR SUCCEEDED IN PHOTOGRAPHING

BY GOOD FORTUNE, WITH THE STORY OF MY EXPERIENCES IN OBTAINING THEIR PICTURES

\section{By \\ GENE STRA'TTON-PORTER}

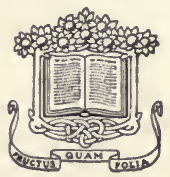

Garden City New York

DOUBLEDAY, PAGE \& COMPANY

1917

39628

$F E B^{\circ} 18$ 
Copyrigit, 1907-1917

Doubleday, Page \& Company

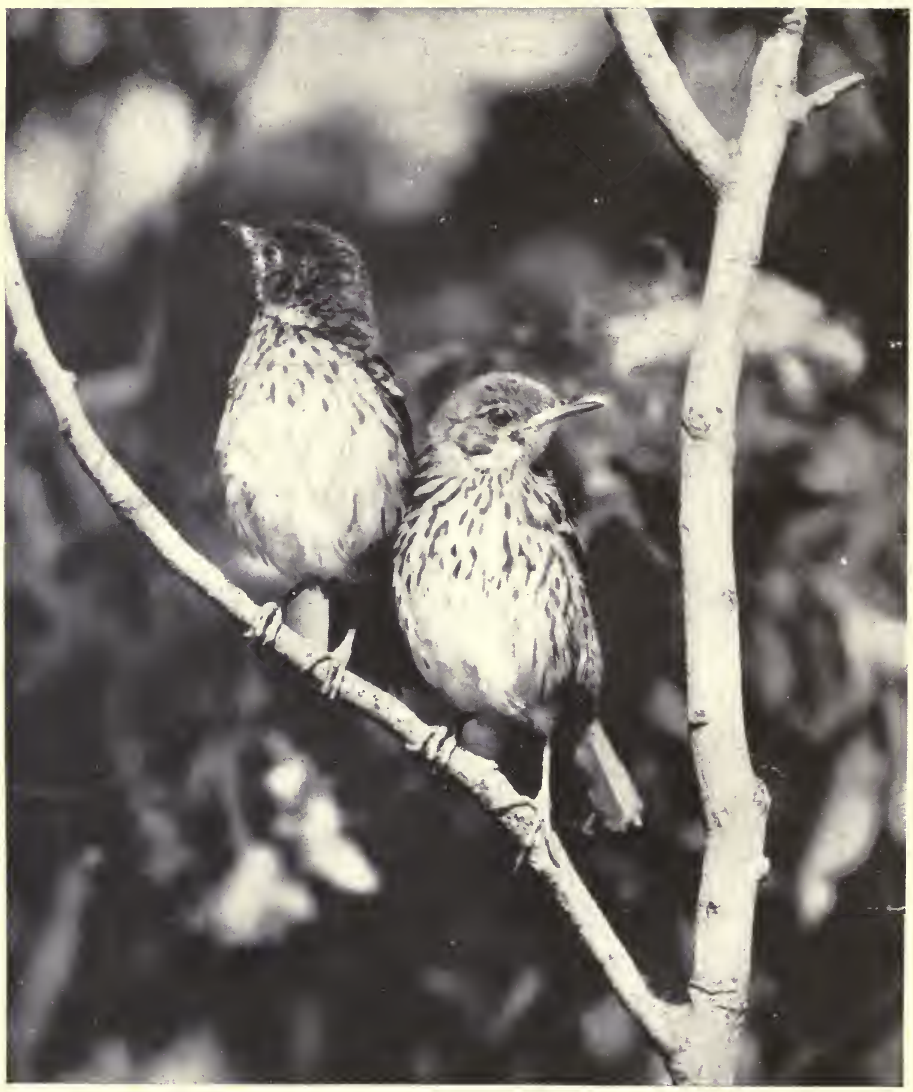

viii

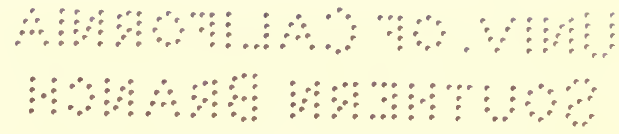




$$
\text { P83f }
$$

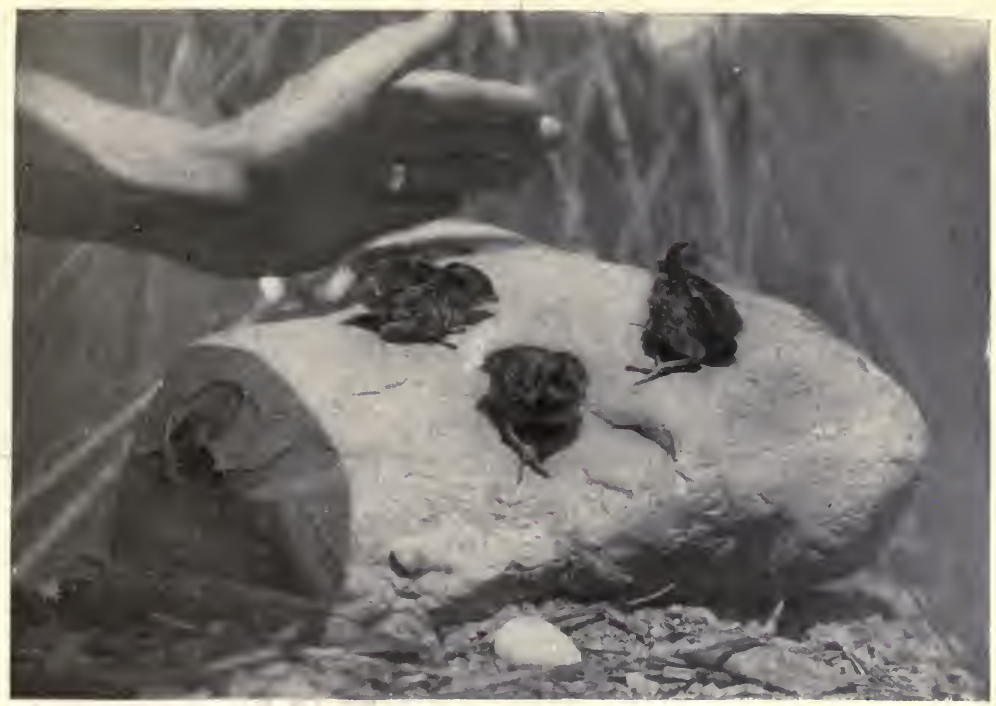

TO

BOB BURDETTE BLACK

$$
\text { WHO "HAD A HAND IN IT" }
$$


Thanks are due to Outing, The Metropolitan, and The Ladies' Home Journal for tile privilege OF REPRODUCING PICTURES COPYRIGHTED BY THEM

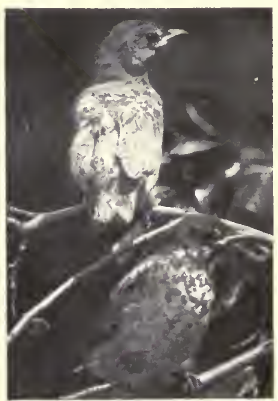




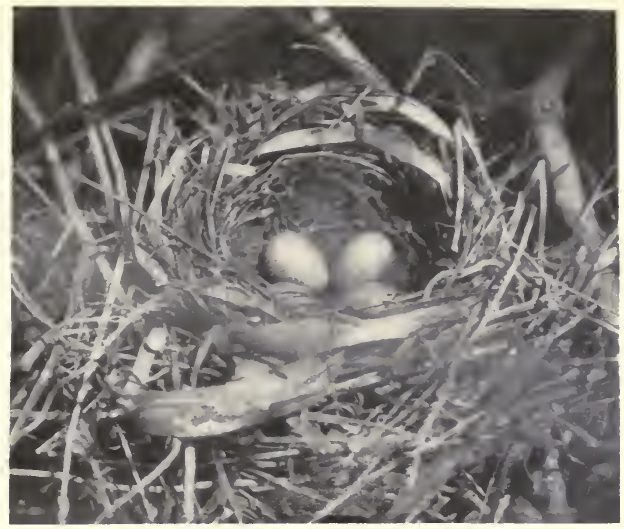

\section{BOOK LIST}

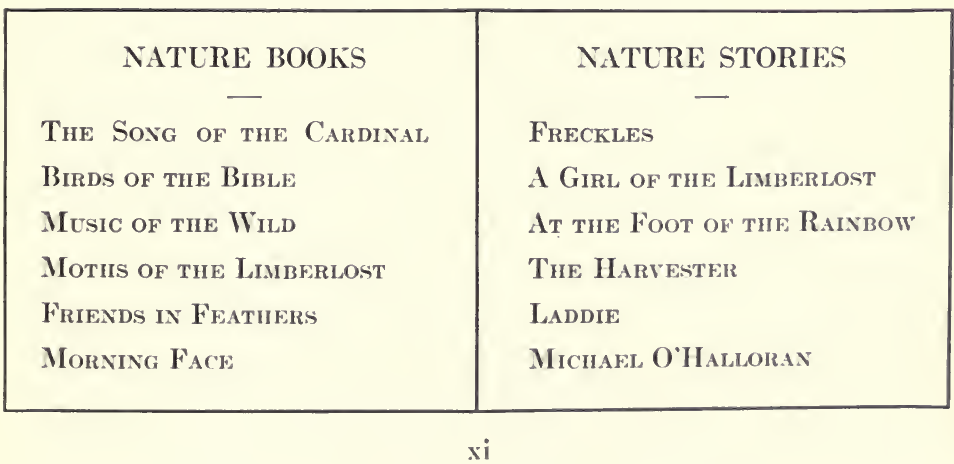




\section{CONTENTS}

CHAPTER

PAGF

I. Friends in Feathers. . . . . . . 1

II. The "Queen" Rail - In a Swamp . . . 31

III. Gold Birds - In the Tree-tops . . . . . 43

IV. The Barn Owl — In Deep Forest. . . . 61

V. Indigo Finch - In Shrubs . . . . . 73

VI. The Wood Thrush - In the Valley of the Wood Robin . . . . . . . 83

VII. Goldfinch - In Bushes . . . . . 93

VIII. The Killdeer — On the Fround . . . . 103

IX. The Bluebird - In Orchards and Bird Boxes . 113

X. The Black Vulture - In the Limberlost . . 193

XI. Robin - In the Dooryard . . . . . . 139

XII. The Purple Martin - In the Air . . . . 159

XIII. The Belted Kingfisher - In Embankments . 16\%

XIV. The Cat-bird - In Thickets. . . . . $18 \%$

XV. The Yellow-billed Cuckoo - In Small Thickly Leaved Trees . . . . . . . . 19 . . . . .

XVI. Wrens - In Bird IIouses . . . . . 217

XVII. The Blue Heron - In the Great Lake Regions. 297

XVIII. The Kingbird - In Orchards . . . . 235

XIX. The Mourning Dove-In Deep Wood and Orchard 249

XX. The Cow-bird - In the Pastures. . . . 261

XXI. TheCardinalGrosbeak-InsmallTreesand Bushes 279

XXII. The Blue Jay - In the Orchard . . . . . 293

XXIII. The Loggerhead Shrike - In Field Trees . . 309

XXIV. The Humming-bird - At the Cabin . . . 321

XXV. The Quail - On the Ground. . . . . 329 


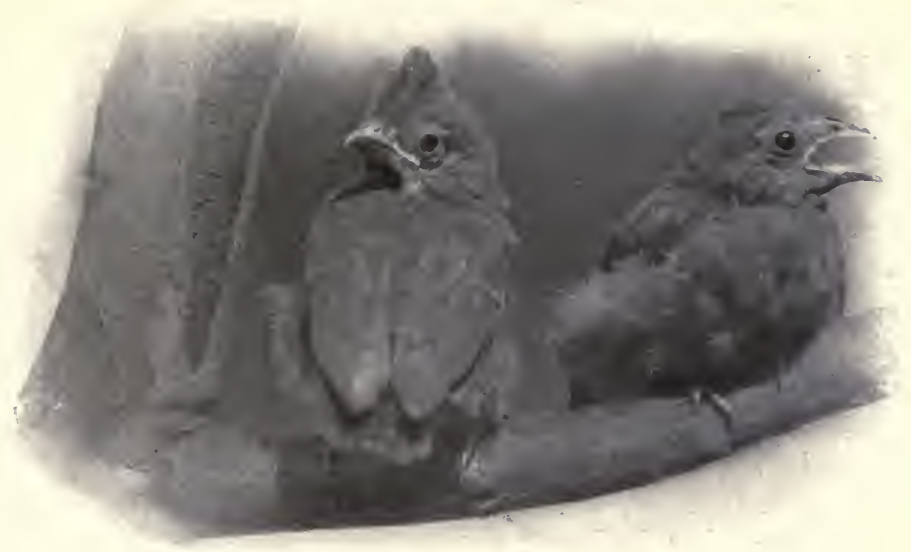

\section{LIST OF ILLUSTRATIONS}

Brooding Cuckoo

Male Cardinal Grosbeak Guarding His Nest Owl

Dusky Falcon

Chicken-hawk

Black Vulture

Shitepoke .

Cardinal Grosbeaks Courting Baby Grosbeak .

Kingfisher.

Young Tanager.

Hen's Nest Containing Egg of Chicken-hawk

Hen Brooding on Egg of Chicken-hawk Owl

Brooding King Rail .
PAGE

Frontispiece XXII 


\section{LIST OF ILLCSTRATIONS-Continued}

Rail Hiding Egg _ . . _ _ 31

Nest of King Rail . . . . . . . . . . $\quad . \quad 36$

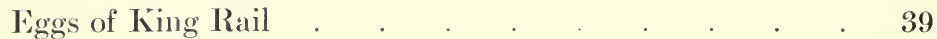

Male Oriole of Wabash Nest . . . . . . . 42

Female Feeding Young . . . . . . . . . . . 43

Ysual Oriole Nest . . . . . . . . . . . . . 46

Reverse of T'sual Oriole Nest . . . . . . 50

Oriole Hung by Accident while Building Nest . . . 51

Young (Orioles . . . . . . . . . 54

Young (Orioles at Bath, Toilet, and Breakfast . . . .55-57

Barn Owl . . . . . . . . . . . 60

Owl Hearl. . . . . . . . . . . . . 61

Barn Owl Leaving Its Home . . . . . . . . 64

The Face a Perfect Heart-shape . . . . . . . . . 69

Typical Indigo Finch Nest . . . . . . . . . 72

Nest of Indigo Finch _ . . . . . . . . . . . 73

Brooding Male Indigo Finch . _ . . . . . . . 76

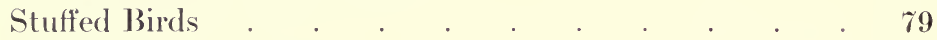

Young Wood Thrushes . . . . . . . . . 82

Nest of Wood Robin. . . . . . . . . . . . 83

Wood Thrush Nest . . . . . . . . . . . 86

Young Bell Bird Hiding Lnder Leaf . . . . . . 90

Male Croldfinch Feeding Young . . . . . . . 92

Female Goldfinch Entering Nest . . . . . . . 93

Female Goldfinch Watching Camera . . . . . . 96

Male Goldfinch at Excrement-covered Nest . . . 100

Young Killdeer . . . . . . . . $10 \%$

The Killdeer Nest . . . . . . . . . . 103

Baby Killdeer Just from Shell . . . . . . . 110

Male Bluebird Carrying Food. . . . . . . . 112

Female Bluebird at Nest . . . . . . . . 113

Bhuebird Nest and Eggs . . . . . . . . 116 


\section{LIST OF ILLUSTRATIONS-Continued}

Young Bluebird.

Black Vulture's Nest with Egg and Young . . . . 122

The Black Vulture's Front Door . . . . . . 123

"Little Chicken" . . . . . . . . . 126

Young Vulture Three-fourths Grown . . . . . 130

Black Vulture Full Grown . . . . . . . . 134

Vulture Taking Flight . . . . . . . . . . 136

Father Robin . . . . . . . . . . . . 138

Robin on Bench on Veranda . . . . . . . . 139

Robin Nest Built on Log of Limberlost Cabin . . . 146

The Robin That Brooded in the Rain . . . . . 152

Robin Ready for First Migration . . . . . . 155

Father Martin . . . . . . . . . . 158

A Martin Double House . . . . . . . . . 159

Martin Standing Sentinel. . . . . . . . 164

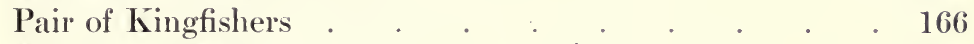

Kingfishers Waiting for Lunch _ . . . . . . 167

The Ilead of the Kingfisher Family . . . . . 174

Young Kingfishers at Entrance to Nest . . . . 178

Kingfisher Flats. . . . . . . . . . 183

Nest of Cat-bird . . . . . . . . . . . 186

Young Cat-bird. . . . . . . . . . . 187

Pair of Young Cat-birds . . . . . . . . . . 190

Young Cat-birds . . . . . . . . . 194

Cuckoo's Nest . . . . . . . . . . . . 196

Brooding Cuckoo . . . . . . . . . 197

Typical Cuckoo Nest . . . . . . . . . . 202

Young Cuckoos . . . . . . . . . . 204

Pair of Young Cuckoos . . . . . . . . . 205

Brooding Female Cuckoo. . . . . . . . 211

Young Cuckoos Ready for Flight . . . . . . 214

Male Wren . . . . . . . . . . . . . . 216 


\section{LIST OF ILLUSTRATIONS-C'ontinued}

Mother Wren

PAGE

Nest and Eggs of Wren .. . . . . . . . . 922

Male Wren Singing . . . . . . . . . . . . 294

Blue Heron Hunting Frogs . . . . . . . . 226

A Frog in His Throat . . . . . . . 227

Indian River Plover. . . . . . . . . . 232

Male Kingbird . . . . . . . . . 234

Female Kinghird . . . . . . . . . 235

Nest and Eggs of Kinglbird . . . . . . . . . . 238

Mother Kinghird Feeding Young . . . . . . . . 242

Kinghird Young. . . . . . . . . . 246

Brooding Dove. . . . . . . . . . 248

Nest of Doves .

Dove Nest in Apple Tree. . . . . . . . . 252

Young Doves of Apple Tree . . . . . . . . 258

Nest of Warblers with Two Cow-birds. . . . . . 260

Cows and Their Feathered Namesakes. . . . . 261

Nest of Indigo Finch C'ontaining Egg of Cow-bird . . $\quad 26(;$

Nest of Vireo with Eiggs of Builder and One of Cow-bird . 269

Pair of Young Vireos . . . . . . . 272

Inverted Nest of Song Sparrow Showing Walled-in Egg of Cow-bird . . . . . . . . . 273

Pair of Young Cow-birds . . . . . . . 275

The Cardinal Grosbeak . . . . . . . . 278

Young Cardinals . . . . . . . . . . . . . $\quad .279$

Nest of Cardinal Crosbeak . . . . . . . 282

Male Cardinal Singing . . . . . . . $\$ 986$

Cardinal . . . . . . . . . . . . . . $\quad 289$

Male Jay Singing _ . . . . . . . . . . $\quad 999$

Blue Jay . . . . . . . . . . . . . . 293

Jay Nest in Elm _ . . . . . . . 294

Mother Blue Jay and Young . . . . . . . . 296 


\section{LIST OF ILLUSTRA'TIONS-Continued}

Baby Blue Jay Asking for Food • • • • • . 297

Family Cares of Blue Jay . . . . . . . . . 300

Young Jays Ready to Fly . . . . . . . . 304

Young Jay . . . . . . . . . . . . . 306

Young Shrike . . . . . . . . . . . . . . 308

Loggerhead Shrike . . . . . . . . . . . 309

Nest and Eggs of Shrike . . . . . . . . . 312

Young Shrikes . . . . . . . . . . 314

Young Shrikes Posing . . . . . . . . . 317

Male Humming-bird . . . . . . . . . . 320

Humming-bird . . . . . . . . . . 321

Nest of Humming-bird . . . . . . . . . . . . . 326

Quail in Hiding . . . . . . . . . . . 328

Nest of Quail Eggs . . . . . . . . . . . . 329

Nest of Quail Shells . . . . . . . . . . . . 335

Quail . . . . . . . . . . 337 


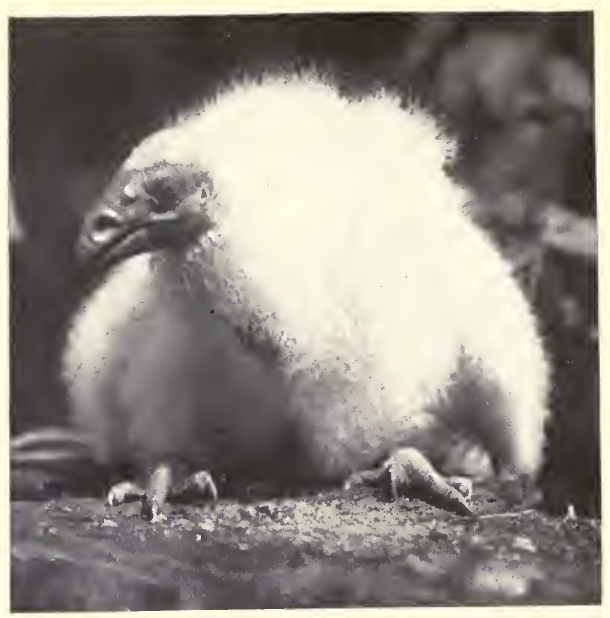

\section{FRIENDS IN FEATHERS}

xviii 


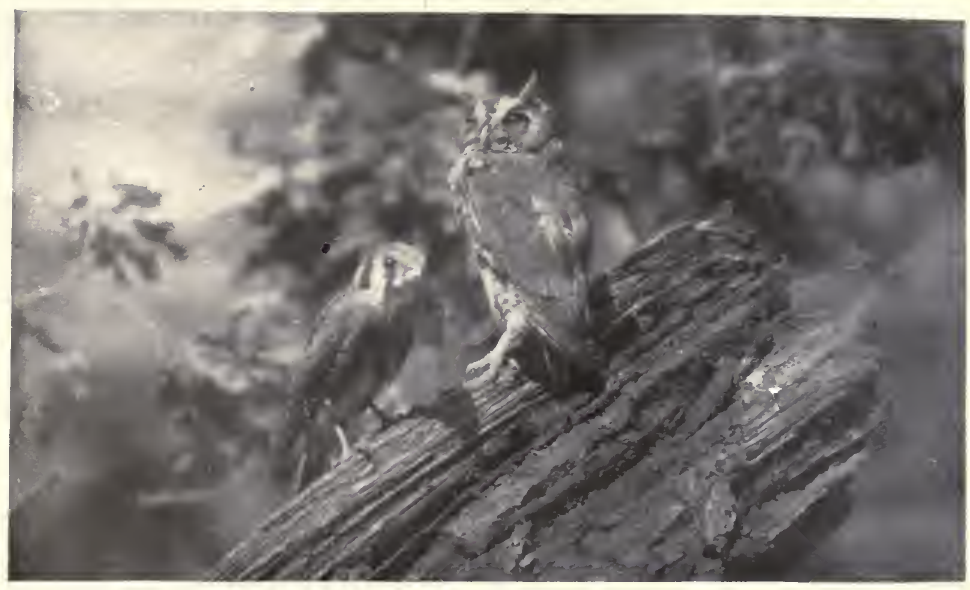

Cried Falco Sparverius: "I chased a mouse up this log." Hooted Scops Asio: "I ehased it down a little red lane." 
"The bubbling brook doth leap when I come by,

Because my feet find measure with its eall;

The birds know when the friend they love is nigh,

For I am known to them, both great and small,

The flower that on the lonely hillside grows

Expeets me there when spring its bloom has given;

And many a tree and bush my wanderings knows,

Ind e'en the clouds and silent stars of heaven."

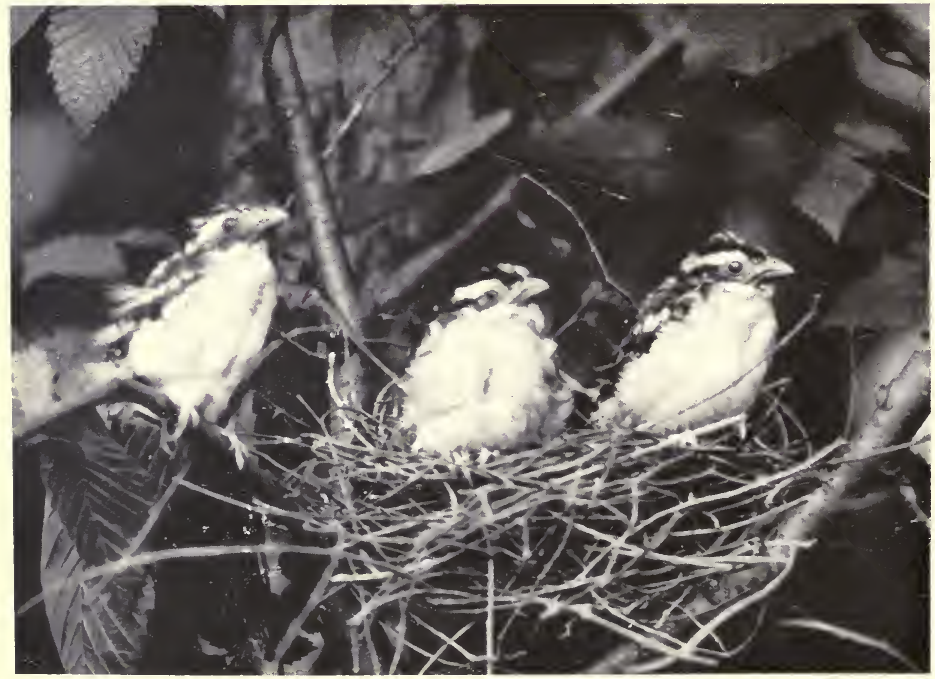

XX 



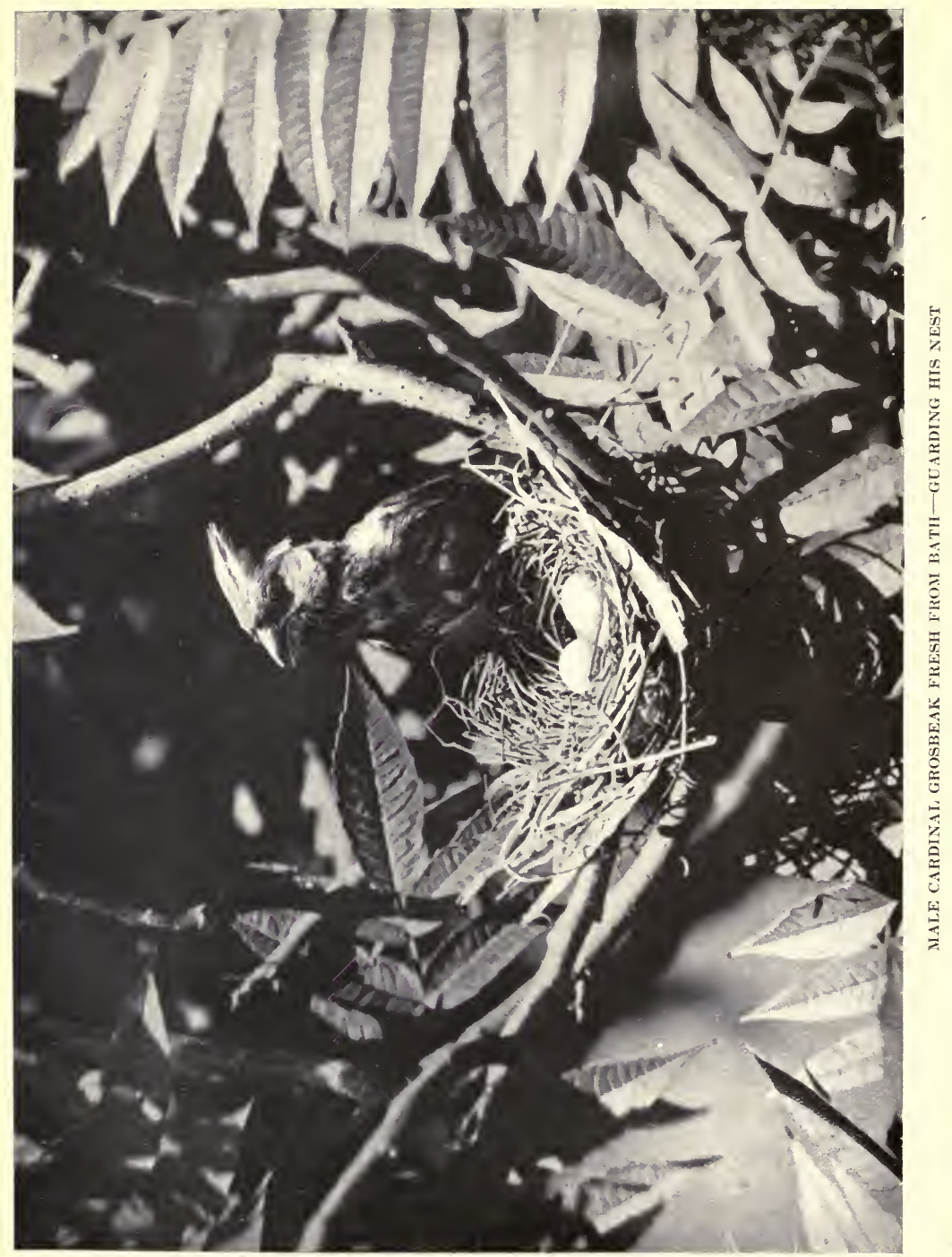




\section{CHAPTER I}

\section{Friends in Feathers}

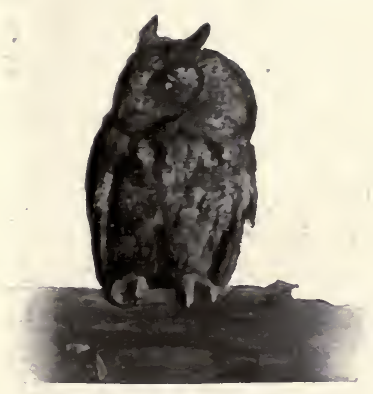

The greatest thing possible to do with a bird is to win its confidence. In a few days' work around most nests the birds can be taught so to trust me, that such studies can be made as are here presented.

I am not superstitious, but I am afraid to mistreat a bird; while luck is with me in the indulgence of this fear. In all my years of field work not one study of a nest, or of any bird, has been lost by dealing fairly with my subjects. If a nest is located where access is impossible without moving it, an exposure is not attempted; but as surely as the sun rises on another morning, another nest of the same species will be found within a few days, where a reproduction of it can be made.

Recently, in summing up the hardships incident to securing one study of a brooding swamp-bird, a prominent nature lover and editor said to me emphatically: "That is not a woman's work."

"I do not agree with you," I answered. "In its hardships, in wading, swimming, climbing, in hidden dangers suddenly to be confronted, in abrupt changes from heat to cold, or from light to dark, field photography is not a woman's work; but in the matter of finesse in approaching the birds, in limitless patience in 


\section{FIRIENDS IN FEATHERS}

awaiting the exact moment for the best exposure, in the tedious and delicate processes of the dark room, in the art of winning bird babies and parents, it is not a man's work. No man ever has had the patience to remain with a bird until he secured a real character study of it. A human mother is best prepared to understand and deal with a bird mother.'

This is the basis of all my field work: a mute contract between woman and bird. In spirit I say to the birds: "Trust me and I shall do by you as I would be done by. Your nest and young shall be touched as I would wish some giant, surpassing my size and strength as I surpass yours, to touch my cradle and baby. I shall not tear down your home and break your eggs or take your naked little ones from your nest before they are ready to go, leaving them to die miserably. I shall come in colours to which you are aceustomed, move slowly and softly, not approaching you too close until your confidence in me is established. I shall be most careful to feed your young what you feed them; drive away snakes and squirrels, and protect you in every way possible to me. Trust me, and go on with your daily life. For what small disturbance is unavoidable among you, forgive me, for through it I shall try to win thousands to love and to shield you."

That I frequently have been able to teach a bird to trust me completely, these studies prove; but it is possible to go even further. After a week's work in a location abounding in every bird native to my state, the confidence of the whole feathered population has been won, so that I could slip quietly in my green dress from nest to nest, with not the amount of disturbance caused by the flight of a Crow or the drumming of a Woodpecker. This was proved to me one day when I was wanted at home. A member of my family eame gently and unostentatiously, as she thought, through the wood to tell me. Every Wren began scolding. Every Cat-bird followed her with imperative ques- 



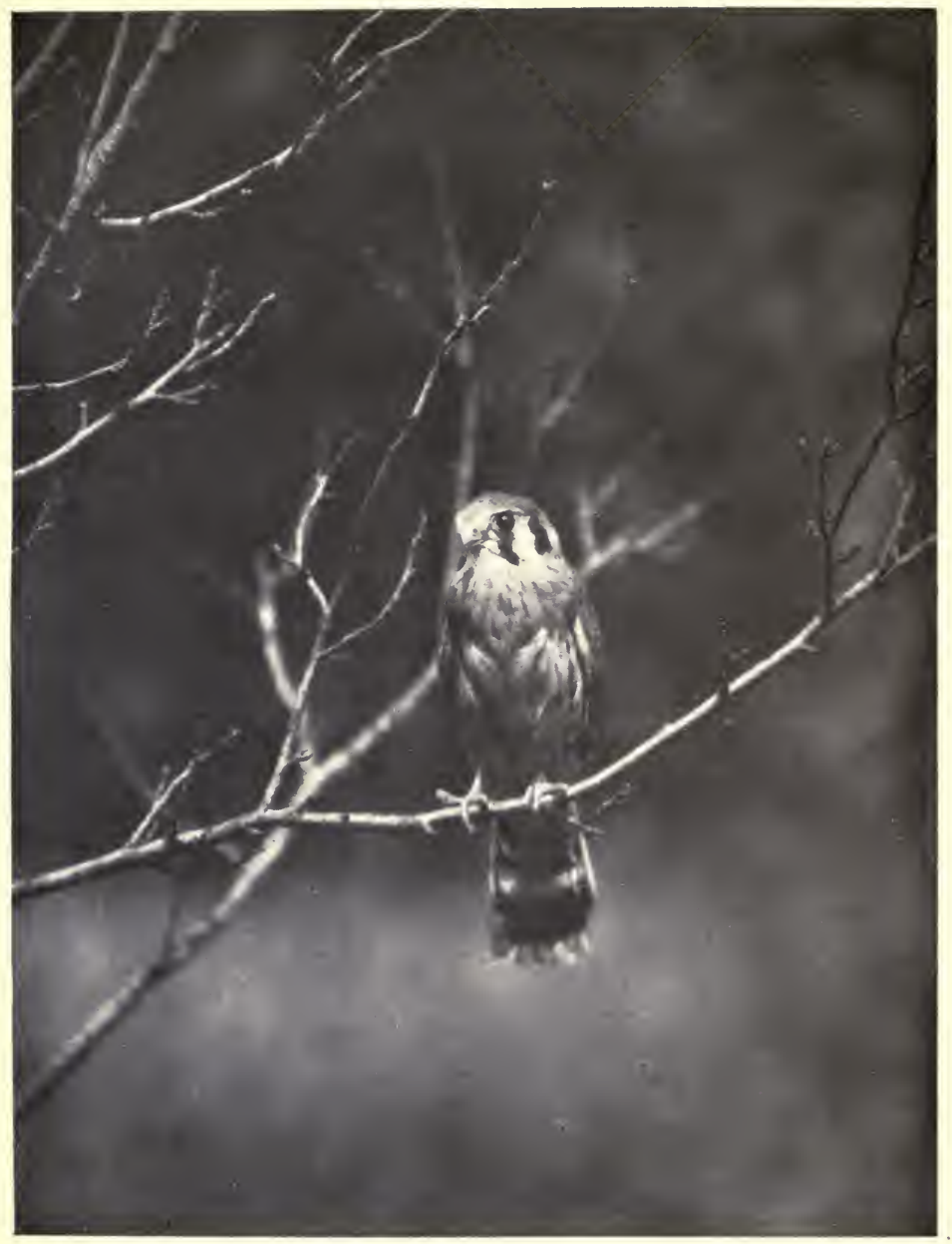

WISDOM-DUSKY FALCON

"A Dusky Falcon is beautiful and very intelligent" 


\section{FRIENDS IN FEATHERS}

tions. Every Jay was on a high perch sounding danger signals. With a throb of joy came the realization that I was at home and accepted by my birds; any other was a stranger whose presence was feared and rejected.

So upon this basis I have gone among the birds, seeking not only to secure pictures of them by which family and species can be told, but also to take them perching in familiar locations as they naturally alight in different circumstances; but best and above all else, to make each picture prove without text the characteristics of the bird. A picture of a Dove that does not make the bird appear tender and loving, is a false reproduction. If a study of a Jay does not prove the fact that it is quarrelsome and obtrusive it is useless, no matter how fine the pose or portrayal of markings. One might write pages on the wisdom and cumning of the Crow, but one study of the bird that proved it would obviate the necessity for most of the text. A Dusky Falcon is beautiful and very intelligent, but who is going to believe it if you illustrate the statement with a sullen, sleepy bird, which serves only to furnish markings for natural-history identification? If you describe how bright and alert a Cardinal is, then see to it that you secure a study of a Cardinal which emphasizes your statements.

A merry war has waged in the past few years over what the birds know; it is all so futile. I do not know how much the birds know, neither do you, neither does any one else, for that matter. There is no possible way to judge of the intelligence of birds, save by our personal experience with them, while each student of bird life will bring from the woods exactly what he went to seek, because he will interpret the actions of the birds according to his temperament and purpose.

If a man seeking material for a volume on natural history, trying to crowd the ornithology of a continent into the working 


\section{FRIENDS IN FEATHERS}

lifetime of one person, goes with a gum, shooting specimens to articulate and mount from which to draw illustrations, he will no doubt testify that birds are the wildest, shyest things alive, because that has been his experience with them.

If he goes with a note-book, a handful of wheat and the soul of a poet, he will describe the birds as almost human, because his own great heart humanizes their every action.

I go with a camera for the purpose of bringing from the fields and forests characteristic pictorial studies of birds, and this book is to tell and to prove what my experiences have been with them. I slip among them in their parental hour, obtain their likenesses, and tell the story of how the work was accomplished. I was born in the country and reared among the birds in a place where they were protected and fearless. I deep love for, and a comprehension of wild things, run through the thread of my disposition, peculiarly erquipping me to do these things.

In one season, when under ten years of age, I located sixty nests, while I dropped food into the open beaks in every one of them. Soon the old birds became so accustomed to me, and so convinced of my good intentions, that they would alight on my head or shoulders in a last hop to reach their nests with the food they had brought. Playing with the birds was my idea of amusement. Pets were my kind of dolls. It dirl not occur to me that I was learning anything that would be of use in after years; now comes the realization that knowledge acquired for myself in those days is drawn upon every time I approach the home of a bird.

When I decided that the camera was the only method by which to illustrate my observations of bird life, all that was necessary was to assemble my outfit, learn how to use it, to compound chemicals, to develop and fix plates; tone and wash prints. How to approach the birds I knew better than anything else.

This work is to tell of and to picture my feathered friends in 



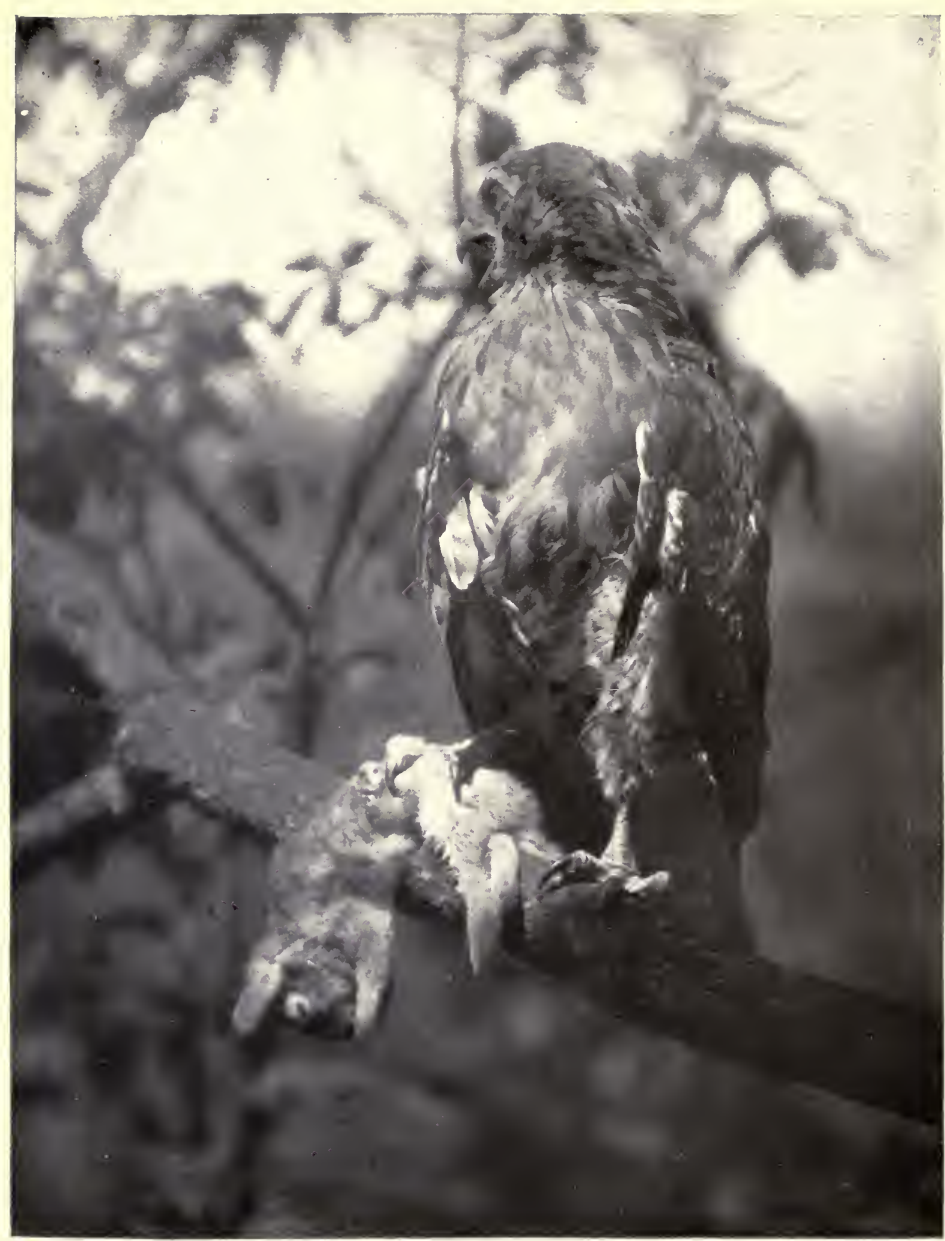

ANGER-CHICKEN-HAWK

"I once snapped a Chicken-hawk with a true expression of anger on his face" 


\section{FRIENDS IN FEATHERS}

their homes. When birds are bound to their nests and young by the brooding fever, especially after the eggs have quickened to life, it is possible to cultivate, by the use of unlimited patience and bird sense, the closest intimacy with them and to secure almost any pose or expression you can imagine.

In living out their lives, birds experience anger, greed, jealousy, fear, and love; also they have their playtimes. In my field experiences I once snapped a Chicken-hawk with a true expression of anger on his face, because a movement of mine disturbed him at a feast set to lure him within range of my camera. No miser ever presented a more perfect picture of greed than I frequently caught on the face of a young Black Vulture to which it was my daily custom to carry food. Every day in field work one can see a male bird attack another male and make the feathers fly, if he comes interfering with his nest and mate. Did humanity ever present a specimen scared more than this Shitepoke when he discovered himself between a high embankment and the camera, and for a second hesitated about deciding in which direction to fly? Sometimes by holding food at unexpected angles young birds can be coaxed into the most astonishing attitudes and expressions.

I use four cameras suited to every branch of field work, and a small wagon-load of long hose, ladders, waders and other field paraphernalia.

Backgrounds never should be employed, as the use of them ruins a field study in three ways. At one stroke they destroy atmosphere, depth of focus and natural environment.

Nature's background, for any nest or bird, is one of evershifting light and shade, forming the atmosphere without which no picture is a success. Nature's backgroind is one of deep shadow, made by dark interstices among the leaves, dense thickets or the earth peeping through; and high lights caused 


\section{FRIENDS IN FEATHERS}

by glossy leaves, flowers and the nest and eggs, if they are of light colour.

Nature revels in strong contrasts of light and shade, sweet and sour, colour and form. The whole value of a natural-history picture lies in reproducing atmosphere, which tells the story of outdoor work, together with the soft high lights and velvet shadows which repaint the woods as we are accustomed to seeing them. It is not a question of timing; on nests and surroundings all the time wanted can be had; on young and grown birds, in motion, snap shots must be resorted to; but frequently, with them, more time than is required may be given. It is a question of whether you desire to reproduce nature and procure a naturalhistory picture, or whether you are going to insert a background and make a sort of flat Japanese, two-tone, wash effect, suitable only for decoration, never to reproduce nature.

Also in working around nests when the mother bird is brooding, the idea is, or should be, to make your study and go away speedily. This is a most excellent reason from the bird's side of the case as to why a background never should be introduced. In the first place, if you work over a nest until the eggs become chilled the bird deserts them; so a brood is destroyed. On fully half the nests you will wish to reproduce, a background could not be inserted without so cutting and tearing out foliage as to drive the bird to desert; to let in light and sunshine, causing her to suffer from heat, and to expose her location until she becomes prey to every thoughtless passer. The birds have a right to be left exactly as you find them.

It is a good idea when working on nests of young birds, where you have hidden cameras in the hope of securing pictures of the old, and must wait some time for them to come, to remember that nestlings are accustomed to being fed every ten or fifteen minites, and even oftener. If you keep the old ones away long, 


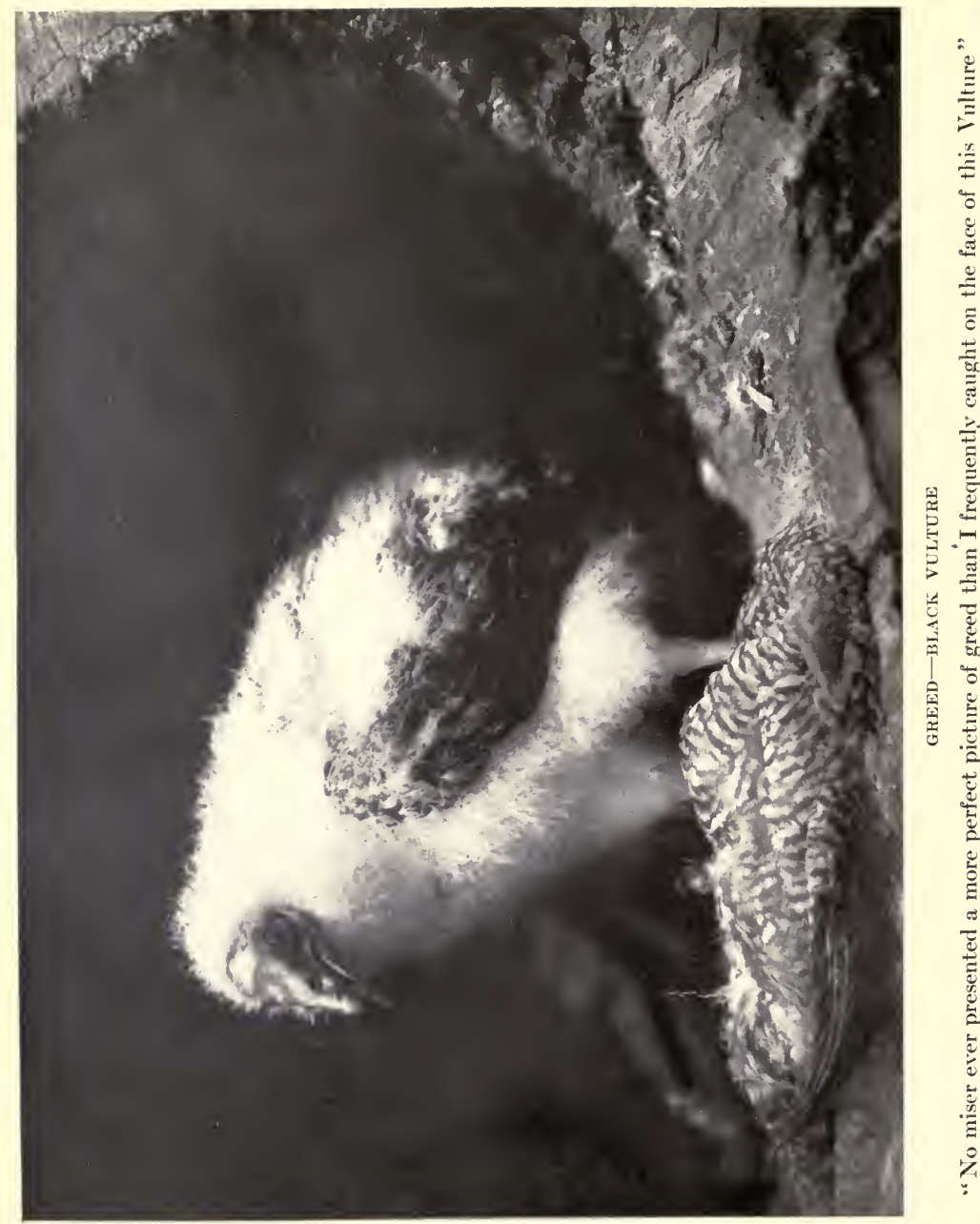


\section{FRIENDS IN FEATHERS}

you subject the young to much suffering and even death; so go to the woods prepared, if such case arises, to give them a few bites yourself. In no possible way can it hurt a young bird for you to drop into its maw a berry or worm of the kind its parents feed it, since all the old bird does, in the majority of cases, is to pick a worm or berry from the bushes and feed it to the young.

When you do not know what to give a nestling, an egg put in cold water, brought to a boil and boiled twenty minutes, thien the yolk moistened with saliva, is always safe for any bird. While you are working so hard for what you want yourself, think of the birds and what they want, occasionally.

The greatest brutality ever practised on brooding birds consists in cutting down, tearing out and placing nests of helpless young for your own convenience. Any picture so taken has no earthly value, as it does not reproduce a bird's location or characteristics. In such a case the rocking of the branches, which is cooling to the birds, is exchanged for a solid location, while the leaves of severed limbs quickly wither and drop, exposing both old and young to the heat, so that your pictures represent, not the free wild life of the thicket and wood, but tormented creatures lolling and bristling in tortures of heat, working to save their lives under stress of forced and unnatural conditions. If you can not reproduce a bird's nest in its location and environment, your picture has not a shred of historical value. My state imposes heavy fines for such work, and soon I hope all others will do the same.

The eggs of many of the birds are pointed and smaller at one end than the other, so mother birds always place these points together in the center of the nest. If you wish to make a study of a nest for artistic purposes, bend the limb but slightly, so that the merest peep of the eggs shows, and take it exactly as the mother leaves it. If you desire it for historical purposes, repro- 


\section{FRIENDS IN FEATHERS}

duce it so that students can identify a similar nest from it. Bend the limb lower so that the lining will show, as well as outside material; then with a little wooden paddle turn at least one egg so that the shape and markings are distinet. This can not possibly hurt the egg and when the bird returns to brood she will replace it to suit herself.

If you find statements in the writings of a natural-history photographer that you can not corroborate in the works of your favourite ornithologist, be reasonable. Who is more likely to know? The one who tries to cover the habits and dispositions of the birds of a continent in the lifetime of one person, or the one who, in the hope of picturing one bird, lies hidden by the day watching a nest? Sometimes a series of one bird covers many days, sometimes weeks, as the Kingfisher; sometimes months, as the Vulture; and sometimes years, as did the Cardinals of this book. Does it not stand to reason, that in such intimacy with a few species, much can be learned of them that is new?

All that my best authority on our native birds can say of the eggs of a Quail is that they are "roundish." He hesitates over the assertion that Cardinals eat insects, and states for a fact that they brood but once a season. No bird is so completely a seed-or insect-eater that it does not change its diet. Surely the Canaries of your cages are seed-eaters, yet every Canary lover knows that if the bird's diet is not varied with lettuce, apple, egg and a bit of raw beefsteak oceasionally, it will pull out its feathers and nibble the ends of them for a taste of meat. Chickens will do the same thing.

Certainly Cardinals eat insects, very freely. The one lure effective above all others in coaxing a Cardinal before a lens was fresh, bright red, scraped beefsteak. Nine times out of ten this bird went where I wanted him when a dead limb set with raw meat was introduced into his surroundings. He would venture 



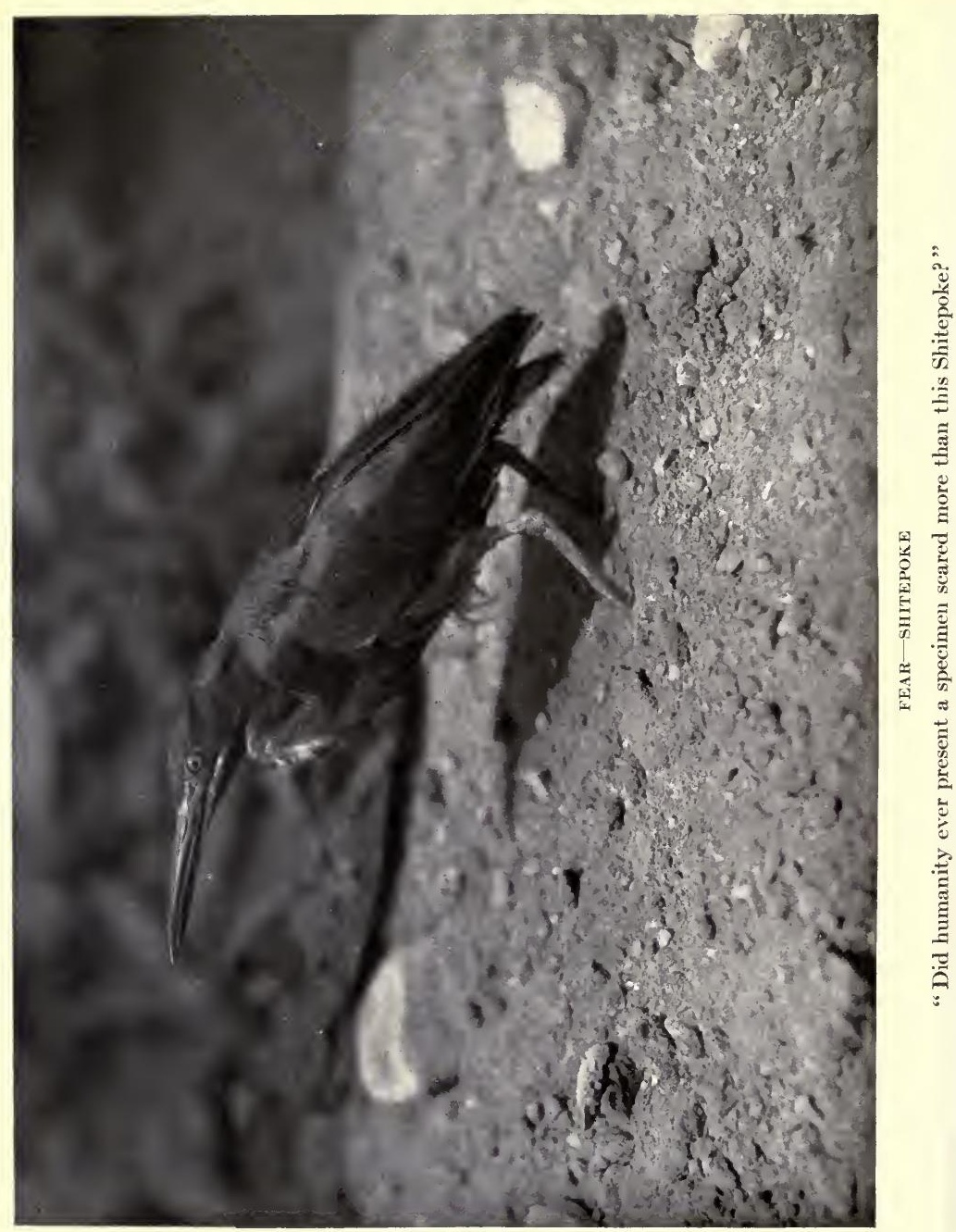




\section{FRIENDS IN FEATHERS}

for that treat what he would not for his nestlings; and how his sharp beak did shear into it!

Ornithologists tell us that the diet of a Black Vulture is carrion. To reasonable people that should be construed as a general rule, but not taken to mean that if a Vulture eats a morsel of anything else it can not be a Vulture. Once during a Vulture series in the Limberlost a bird of this family in close quarters presented me with his dinner. In his regurgitations there were dark streaks I did not understand, so I investigated. They were grass! Later I saw him in a fence-corner, snipping grass like a Goose, while the week following his mate ate a quantity of catnip with evident relish. Then some red raspberries were placed in the mouth of their $\log$ and both of them ate the fruit.

In the regurgitations of a Kingfisher there can be found the striped legs of grasshoppers and the seeds of several different kinds of berries. All grain- and seed-eaters snap up a bug or worm here and there. All insect-eaters vary their diet with bugs and berries, while all meat- and carrion-eaters crave some vegetable diet.

Through repeated experiences with the same pairs I know that Cardinals of my locality nest twice in a season, and I believe there are cases where they do three times, as I have photographed young in a nest as late as the twenty-ninth of August. Had it not been that a pair were courting for a second mating around a nest still containing their young, almost ready to go, such a picture as this pair of courting Cardinals never would have been possible to me. But after one brooding they became so accustomed to me that they flitted close their home, making love as well as feeding the nestlings. Frequently in my work I have followed a pair of Cardinals from one nest to a new location a few rods away where they continued operations in a second brooding. 


\section{FRIENDS IN FEATHERS}

Neither does an authority who tells you certain kinds of birds are the same size, male and female, mean anything except that they are the same on an average. All accepted authorities state that Black Vultures are the same size. My male of the Limberlost was a tough old bird, of what age no one could guess, his eyes dim, his face wrinkled and leathery, his feet incrusted with scale, while he was almost as large as his cousin, Turkey Buzzard. His mate was a trim little hen of the previous year, much smaller and in every way fresh compared with him, but they were mated and raising their family. No ornithologist can do more than to lay down general rules, and then trust to your good sense to recognize the exceptions.

There are pairs of birds in which the male is a fine big specimen, the female small and insignificant. There are pairs where the female is the larger and finer; again, they are the same size. Sometimes they conform in colour and characteristics to the rules of the books, often they do not. Twice in my work I lave found a white English Sparrow, also a Robin, wearing a large white patch on his coat and several white Blackbirds. I once came very close to snapping an old Robin of several seasons with a tail an inch long. It did not appeal to me that he was a shorttailed species of Robin-there is an explanation for all these things. The bird had been in close quarters and relaxed his muscles, letting his tail go to save his body. The Great Horned Owl of our Cabin woods came so near catching our male Cardinal this spring that we found his entire tail beneath the wild grapevines near the spring, while for weeks we have seen the Cardinal daily rocking in ill-balanced flight.

A large volume could be filled with queer experiences among birds. Once I found a baby Robin that had been fed something poisonous, so its throat was filled with clear, white blisters, until its beak stood wide open, while it was gasping for breath 



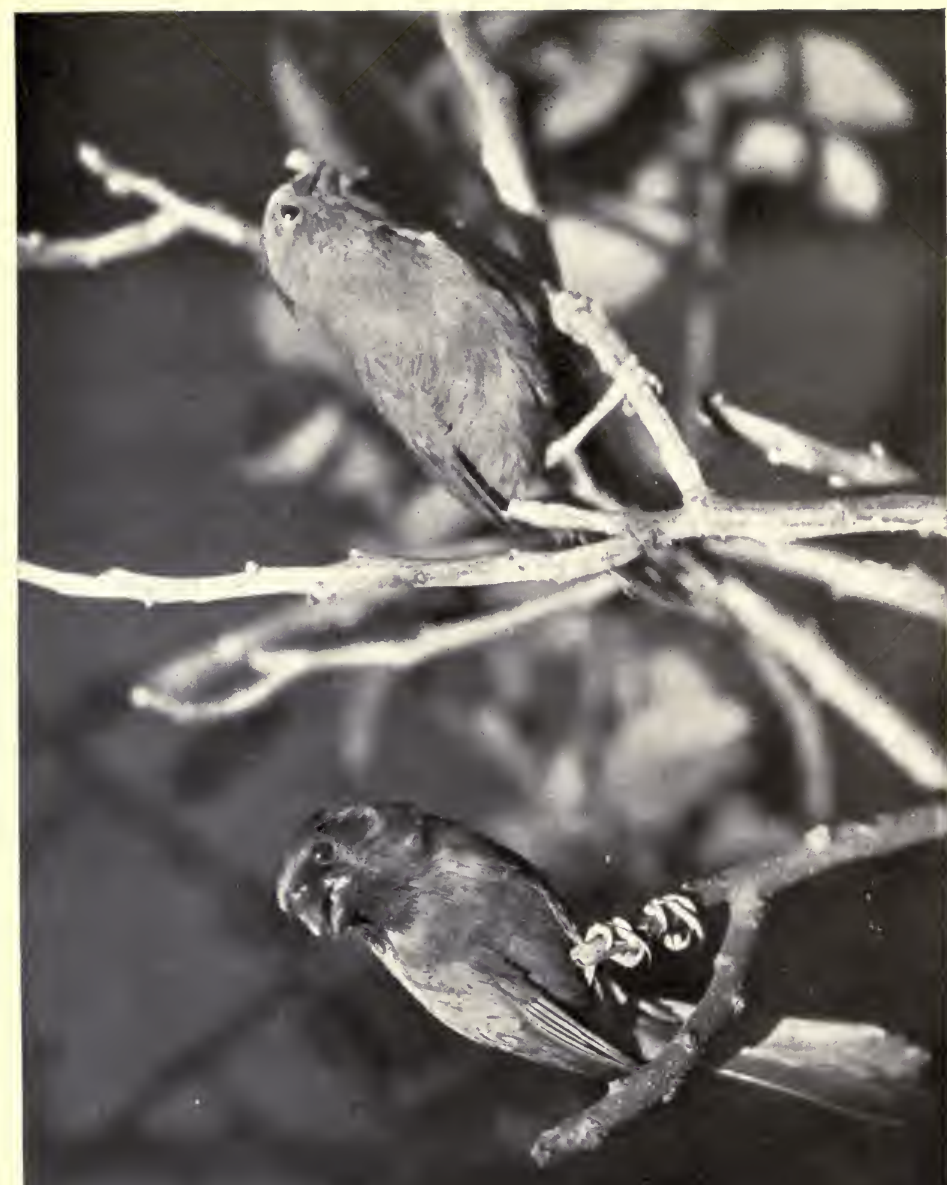

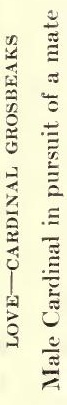




\section{FRIENDS IN FEATHERS}

I punctured the blisters with a needle and gave it some oil, but it died. Another time I rescued a Robin that had hung five inches below its nest by one leg securely caught in a noose of horsehair, until the whole leg was swollen, discoloured, the skin cut and bleeding, and the bird almost dead. Release was all it needed.

Again I came across a Scarlet Tanager a few days before leaving the nest, having both its eyes securely closed and hidden by a thick plastering of feathers and filth. I took it home, soaked and washed it perfectly clean in warm milk. Its eyes were a light pink and seemed sightless. It was placed in the dark, fed carefully, gradually brought to the light, and in three days it could see perfectly and was returned to its nest, sound as the other inmates.

Once I found a female Finch helpless on the ground, and discovered her trouble to be an egg so large she could not possibly deposit it, so she had left the nest and was struggling in agony. I broke the egg with a hatpin and she soon flew away, seemingly all right. With the help of a man who climbed a big tree and secured the egg of a Chicken-hawk, after the Hawk had been shot by a neighbouring farmer, we played the mean trick on a Hen of having her brood on the egg of her enemy.

Another time some boys came to me with a lean baby Shitepoke, scarce old enough to fly, that had landed aimlessly in a ditch filled with crude oil, so the poor bird was miserable past description. Warm water, soft soap and the scrub brush ended his troubles: he was returned to the river clean, full fed and happy, I hope. Walking through the woods one Sabbath morning this spring, after a night of high wind and driving rain, I was attracted by the sharp alarm cries of a pair of Rose-breasted Grosbeaks. I followed them until almost mired in the swamp, and there, on a small tuft of grass, between pools of water and among trampling cattle, within two feet of each other, I found a 


\section{FRIENDS IN FEATHERS}

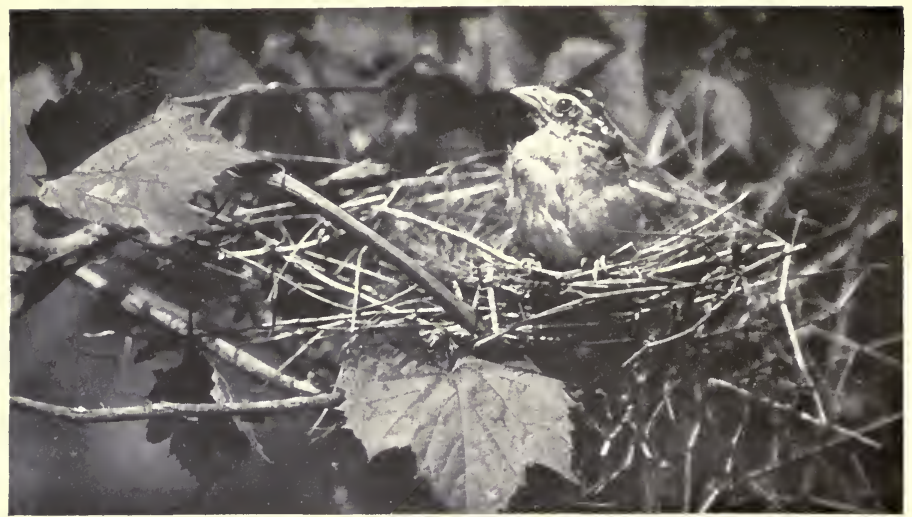

BABY GROSBEAK

male baby Grosbeak and a Scarlet Tanager, neither over five days from the shell. The Tanager nest I could not discover. The Grosbeak was in a slender oak sapling in a thicket of grapevines. The tree was too light to bear my weight, while I was not prepared for field work. To leave them meant for both to be drowned or trampled by the cattle. I carried them home in my hands. That night I read that a young Hawk taken from his coarse nest of sticks and placed in a soft nest would die miserably, so the following morning I took a ladder and went back to the swamp. There had been some woodland tragedy other than the storm. The nest contained one baby, dead and badly abused, so I carefully cut the surrounding vines and brought the cradle home to my birds. Then for ten days, in the midst of my busiest time on this book, a stop every fifteen minutes was made to feed those youngsters a mixture of boiled potato and egg, varying with a little mashed fruit or bread and milk. 



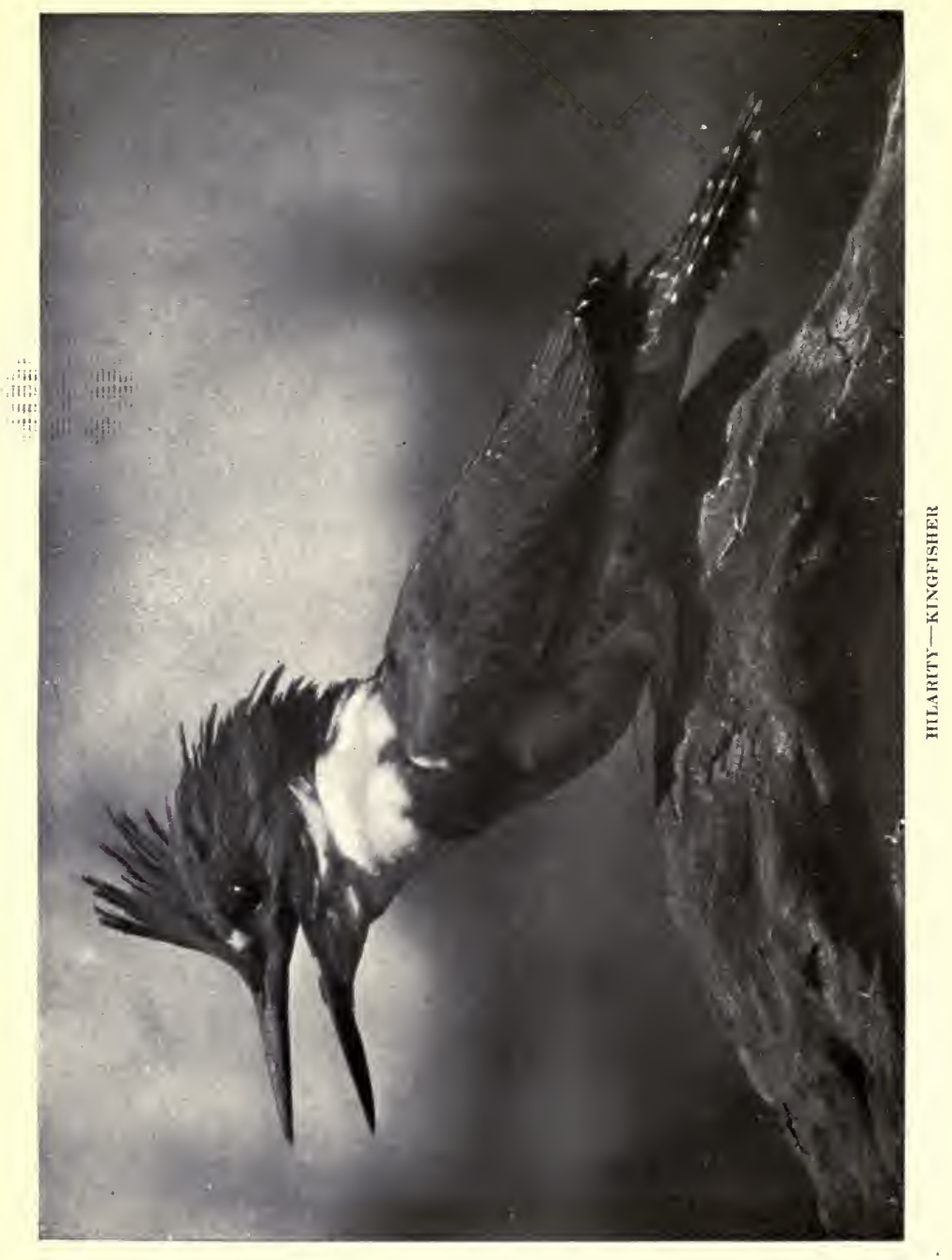




\section{FRIENDS IN FEATHERS}

They grew wonderfully. When they were large enough to fly well they were given the freedom of the conservatory, then the door was left open, and finally they were placed in an apple-tree with food and water beneath. As I write they are six weeks old. Bath water is still furnished them, but they have not been fed for ten days. Both of them are flying in the orchard, clean, bright, beautiful birds. I was most anxious to keep them,

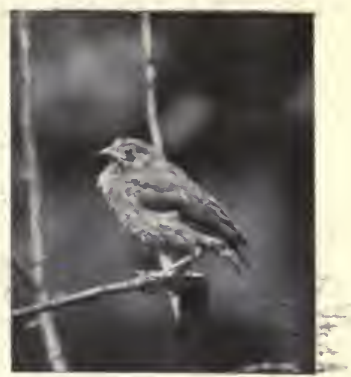

YOUNG TANAGFR. the Grosbeak especially. It would have made a precious pet, but the laws of my state prohibit the caging of a song-bird, so gradually I had to accustom them to become self-supporting, take their pictures, and let them go.

While working among birds in the nesting season I have se cured these intimate studies and experiences. At any other time, when they are the wild, shy, free creatures of all outdoors, a preconceived study of them is the merest chance, and a stray snap shot, luck, pure and simple. - This, of course, refers to songsters; with coast, tropical and polar birds that live in flocks it is different.

But do not let anyone imagine because he knows his nat-

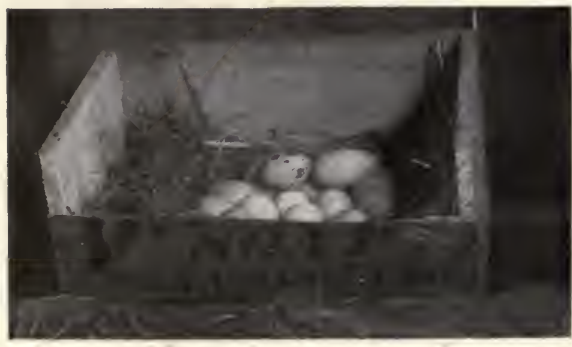

HEN'S NEST CONTAINING EGG OF 'CHICKEN-HAWK ural history well, that he knows anything about the camera. That is a separate and distinct study. You might as well ask a great surgeon to do X-ray work without knowing how, as to ask it, scientist to judge 


\section{FRIENDS IN FEATHERS}

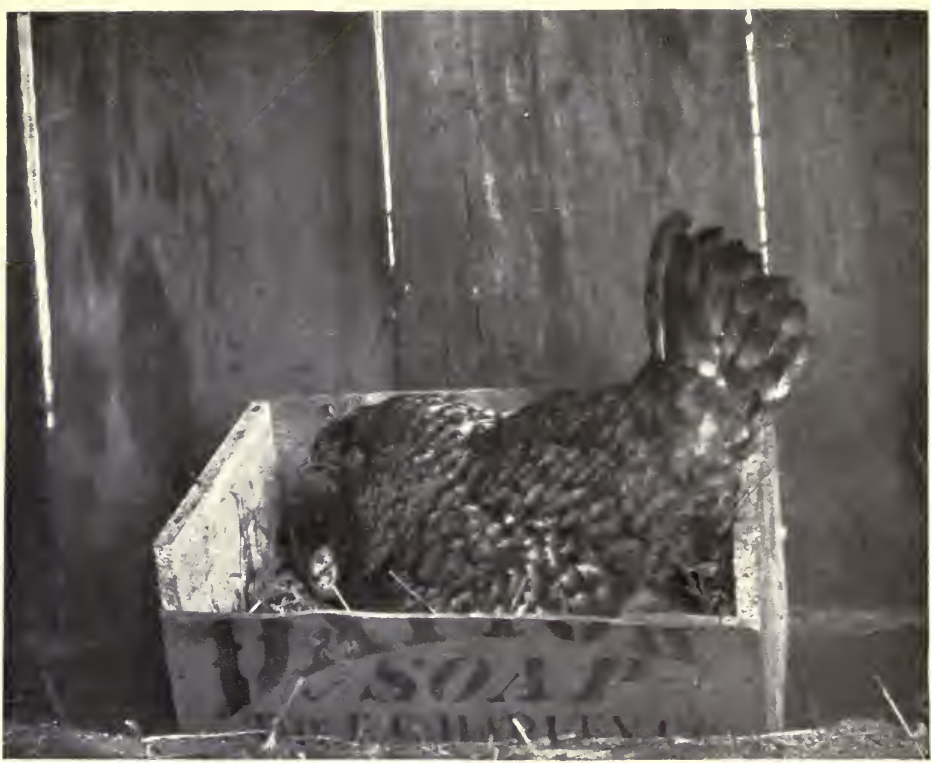

"We played the mean trick on a /Hen of having her brood on the egg of her worst enemy"

a natural-history photographer's work. It is possible to locate a favourite stump and photograph one or a pair of Kingfishers in the act of diving for food. It is possible by his droppings to locate a Pheasant's drumming log, hide a camera and take him drumming, fighting another cock, or mating. It is possible to locate a Heron's fishing grounds and take him frogging at any time in the season. These are the things which seldom happen, and which are rare luck, but they are perfectly feasible to one who has mastered the art of setting and hiding a camera and making the most of a poor plate. 


\section{FRIENDS IN FEATHERS}

I have done some of these things; but for the most part these are simple little stories of happenings that occur every day in field work. This book tells how my birds were approached, to what extent their confidence was gained, and how much time was required; it will show the studies and will explain what of courage, strength, and patience they cost.

My closet contains hundreds of negatives of nests, young birds fully feathered on the day of leaving the nest and mostly in pairs, many series from nests to grown birds, some extending over three months; and grown birds in the act of diving, bathing, flying, singing, in anger, greed, fear, taking a sun bath, and courting. I have two studies of birds when the pair were forming their partnership, one of a male bird standing sentinel beside his brooding mate, and one of a pair of Kingfishers on a stump in their favourite fishing shoal.

In cases where nestlings are similar in form and colouring to their elders, I have preferred to use the young in pairs, because my heart is peculiarly tender over these plump, dainty, little creatures, so I fancy others will feel the same.

Every picture reproduced is of a living bird, perching as it alighted, in a characteristic environment. I have no gallery save God's big workshop of field and forest, while my birds are bound by no tie save the bond of friendship between us.

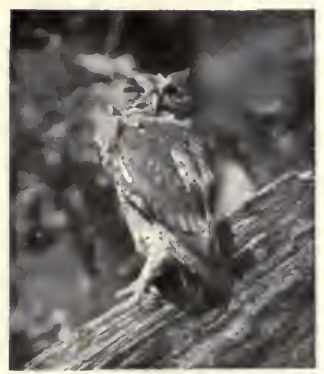

27 
"Spirit that moves the sap in spring, When lusty male birds fight and sing,

Inform my words and make my lines

As sweet as flowers, as strong as vines."

-Thompson. 



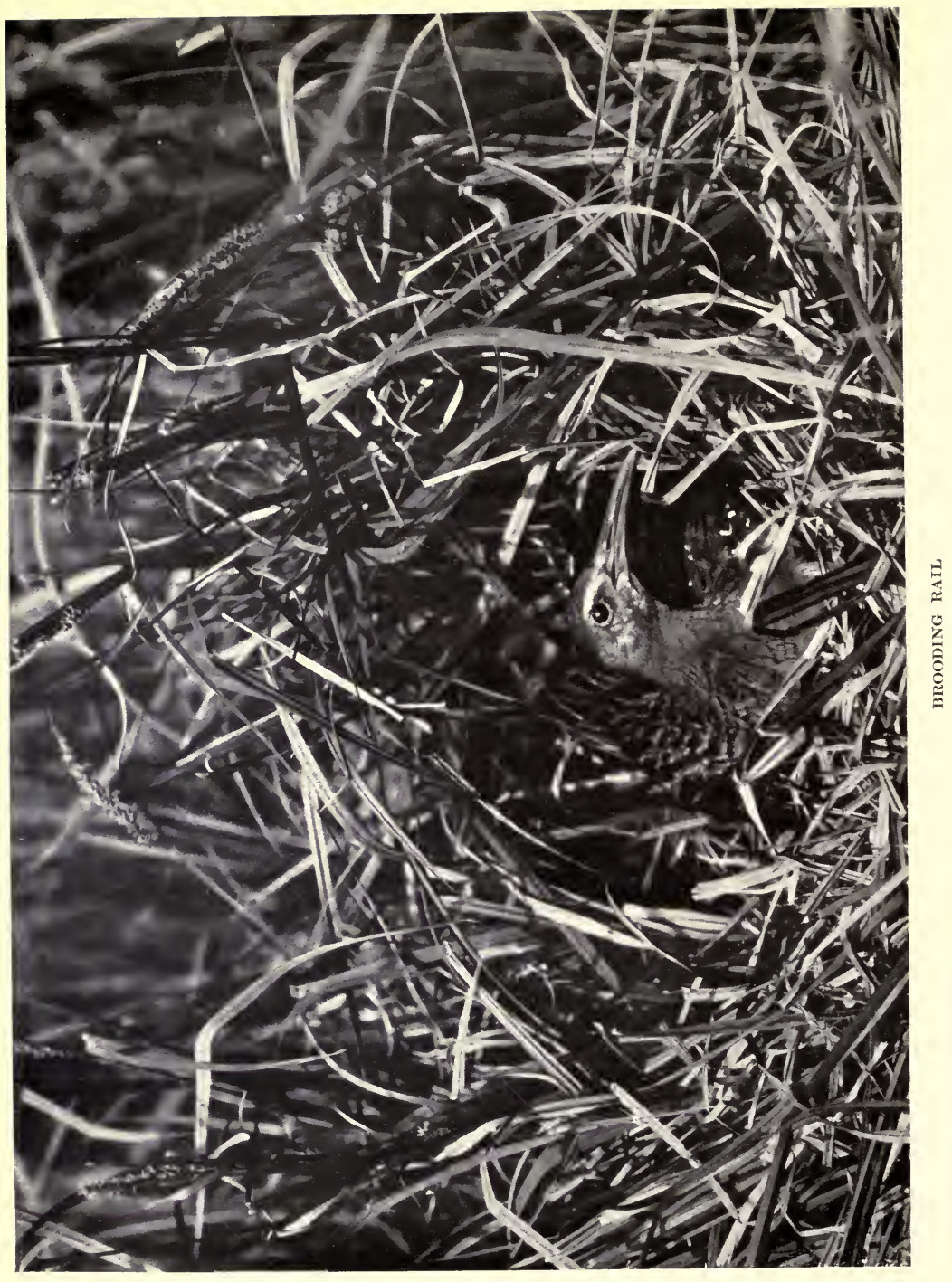




\section{CHAPTER II \\ The "Queen" Rail: Rállus Élegans}

IN A SWAMP

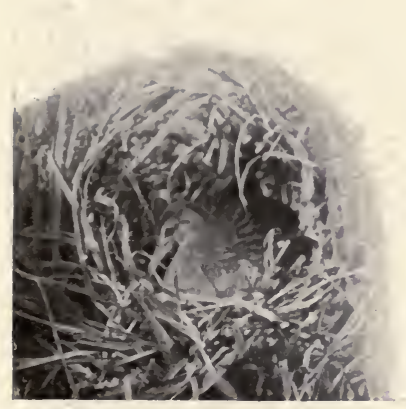

HIDING AN EGG FROM SIGHT

There are particularly fine specimens among birds and animals as well as among men; and for this reason one bird no more represents the whole of its species than one man represents his entire race. The greatest thing ever done with a bird was to win its confidence. I have done this in the case of many brooding birds, but never to a degree surpassing this instance.

One evening one of the Faithful brought me word that seven miles east of the Cabin, in a small swamp in one corner of Eli McCollum's corn-field, "a big bird was brooding." A message like that means everything delightful to a' natural-history photographer, so I could scarcely await the coming morning to be on my way. That night I dreamed of a large bird that carried me on its back across a waving green swamp and kindly poised in air above its nest while a study of its eggs was made.

Early the following morning I donned my swamp outfit, packed four cameras and started. The road wound to the northeast through new country; there were hills and hollows to 


\section{FRIENDS IN FEATHERS}

which I was not accustomed, while all May was in each intoxicating breath of spring air, in the Lark's note o'erhead, and in every whitening corner of the old snake fences outlining my way.

A passing farmer directed me to McCollum's, and standing in my carriage, I could see a corn-field with a small swamp in one corner. I turned from the broad highway to drive up a narrow country road such as one reads of, but seldom finds. Crisp, thick grass grew to the wheeltracks, big oaks and maples locked branches overhead, while every fence-corner was a blanket of bloom above and a carpet of bloom below.

The corn-field, mellow with alternate freezing and thawing, outlined in symmetrical rows by the brown stubble of last year's crop, green splotched with rank upspringing mullein, thistle; dog-fennel and smartweed, drowsed in the warm sunshine. It was enclosed by a snake fence, so old that it had become a thing of great beauty and most interesting. There must have been a time when that fence shone with the straw colours of newlysplit timber giving off sappy odours. Now, it was blacker than the bark of big trees that had grown from the acorns and beech-nuts the squirrels had dropped in its corners; while it was hoary with the lint that wasps and Orioles love to gather in nest-building, and gay with every endless shade of gray and green that ever harmonized on the crimpled face of a lichen. There were places where the old fence stoutly bore up its load of bitter-sweet and woodbine, wild grape and blackberry; again it slid down dejectedly, as if the years were heavy upon it, while the wood, soggy with earth's dampness, grew tiny ferns, mosses and brilliant fungi.

I almost forgot the bird of which I had dreamed, in my delight over the fence. Every rail of it was a tenement. Some housed woodworms, ants and beetles; hollow ends and knot-holes sheltered brooding Sparrows and Pewees; small mud-plastered spots marked the walled-in families of boring wasps. Garter 


\section{THE "QUEEN" RAIL}

snakes, moles and field mice homed in and under the rotting bottom rails, bright green lizards liked to laze on the sunny sides of the middle ones, while sleek ground squirrels, with blackstriped backs, ran on the top.

In the corners on either side grew rank orchard grass, thickly sprinkled with sweet-Williams, while laughing-faced blue-eyed Marys coquetted with them through the cracks. Graceful maiden-hair ferns tossed their tresses from wiry stems. Bleached mandrake umbrellas, that would later unfurl shades of green to shelter cups of wax and gold, pushed stoutly through the sod. Half the corners were filled with the whiteness of wild plum and service-berry; the others were budding the coming snow of alder and the blush of wild rose. Papaw sheaths were bursting with the pressure of coming leaf and wine-coloured bloom, and rich red and yellow buckeye buds were pursy with swelling flower and foliage.

"Nu-m-m-m-m-m-m!" came the low rumble of a swamp bird. "Gyck! Gyck!" came the answer; then the fence was forgotten. The camera I selected to use weighed forty pounds, the field was mellow and the swamp at its farthest corner. Close study was required to locate the nest, but at last, by only a few grass blades persistently arched against the wind, I found it. Then putting on my waders and carefully probing with a long tripod for each step, I entered the swamp and started toward the nest.

The birds fear noise far more than objects, so I made a long wait between steps and shifted my feet sidewise so as not to sink so deep in the muck that I could not get out. It was difficult work to take a step, while I sank deeper and deeper on nearing the nest. Coming close I made longer pauses between steps. When I was almost to the nest, from the heart of the swamp broke a sharp "Gyck! Gyck!"- the same cry that I had heard on the road; then I knew that it came from the King Rail and that he was anxious about his Queen. 


\section{FRIENIDS IN FEATHERS}

She had chosen her location on a small hummock, far out in a deep pool; so few inches above the water that while brooding she could take a drink without rising. The erection of her palace evidently had heen simplicity itself. She had snipped this year's green grass from her location, sat down on the old dead, dry blades, and repeatedly turned around. Then she had gathered the ends she had broken off, dropped them under her and worked them down with her feet. This gave her a large, flat, bowl-shaped nest of beautiful shades of tan, yellow and brown dried grass. The finishing touch was to catch the long rank-growing blades above her head, draw them together and weave them into an arch of living green.

Through its sides the brooding Rail could be seen. She was a large, splendid specimen of her species, her plumage a bright beautiful brown, with little $\mathrm{V}$-shaped markings of white over her back and touches of black on the wings, in the shape of black feathers twice banded with white. The top of her head was a smooth even brown having ash-coloured streaks above the eyes. Her throat was paler ash. Later I saw that her legs were slender, smooth, a light greenish yellow, and her feet graceful, with slim toes ending in sharp black nails. Her beak was elegant in its symmetrical curve, with hints of red and yellow at the base, daintily cut nostrils and rich ivory tip. But loveliest of all were her big, wise, wonderful eyes, as she sat motionless, steadily regarding me.

As I returned her fearless gaze the thought came to me, that if the King Rail earned his royalty by personally conducting the migratory voyages of the Quail, as he was accredited with having done at the time of his coronation in early France, his mate undoubtedly was worthy of equal honours; for she was graceful and lovely, having a heart that was unafraid, as royal hearts ever should be. Straightway I named her the "Queen," and our friendship began. 



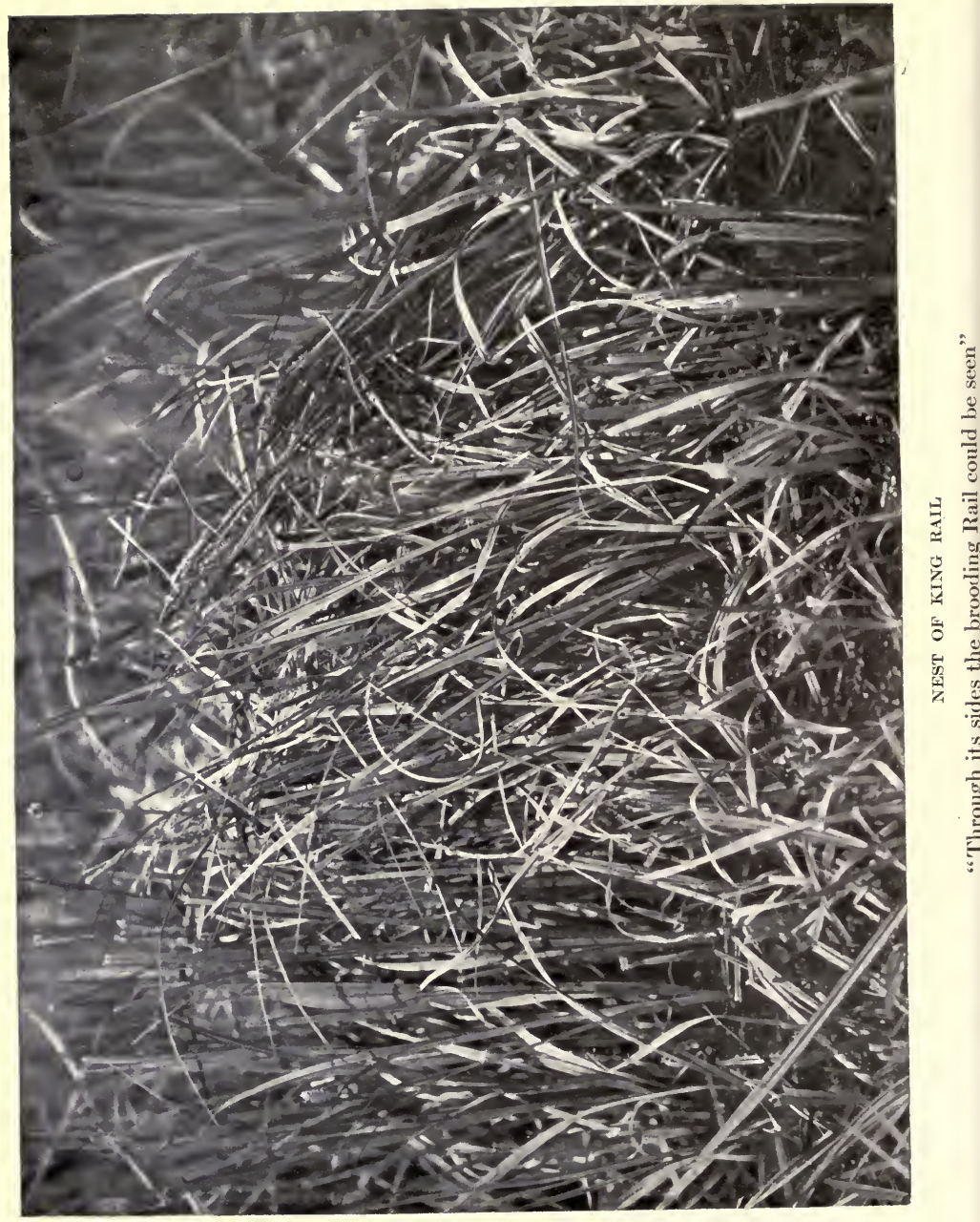




\section{THE “QUEEN" RAIL}

After remaining quietly around her until convinced that she was not frightened, I worked my way to the bank and carried my camera into the swamp, setting it up fifteen feet from the nest, by the use of a long water tripod, then covering it with rushes. With the bulb of a long hose in one hand I slowly waded toward the nest, stooping to reach under water to cut the intervening grasses from the foreground of my picture. On nearing the nest I worked slowly, studying every movement to make it noiseless and simple. It was not so easy, for the water was very cold, the muck deep and sticky, while constant watching was required to avoid sinking above my waders in a net-work of muskrat burrows. In my absorption I forgot how nearly I was approaching the nest, until suddenly there came between the grasses a flash of ivory, then a red stain spread on my bared arm.

I almost cried aloud for joy. Every second I had feared my "Queen" would flatten her feathers and dart into a welldefined runway, that could be detected leading from one side of the nest into the swamp. But this was pure glory. She was a fighter. She would remain. Talk about excitement! My hair pricked my head; my heart muffled up in my throat as I stooped low, slowly and carefully parting and bending back the grasses of the nest, while the "Queen" struck me without mercy. My hands and arms were seeping blood in twenty-three places when the nest was opened to my satisfaction; but the "Queen" had not showed the slightest inclination to leave it when I finished the exposure and closed it again.

Every day for seven days I slipped into the swamp, set up my camera, closer and closer each time, and opened that nest. Each day the "Queen" paid less and less heed to me. On the day that I travelled those fourteen miles for the seventh time, my camera was set with no covering at all, exactly where it was wanted, the grasses parted widely, without the slightest protest 


\section{FRIENDS IN FEATHERS}

from the bird; she did not move or open her beak, while she neither looked nor felt afraid or annoyed. Then with a slow plate and time exposure, the frontispiece of this chapter was made; a study of a bird that any hunter will tell you is one of our wildest, shyest creatures.

After changing the plate, I desired a reproduction of the nest and eggs to complete the series. As the "Queen" would not leave, I gently picked her up, being extremely careful to lift her straight above the nest, so as not to break an egg. Holding her on my breast, with her head slipped inside my blouse, that she might not be alarmed by seeing me touch her eggs, I made an exposure on her nest.

Her eggs were twelve in number, four and one-half inches around the long way and three and three-quarters at the larger end, by the best measurements I could secure and hold the "Queen" with one hand. They were of a pale ash-colour, sparsely sprinkled with splotches of reddish brown and faint lavender markings that seemed as if seen through a thin, oily veil. In the golden bowl with the green arch above they were exquisite.

Then I set the "Queen" on the edge of her nest and kissed the top of her shining head in parting, for I knew what was on those plates. The grasses of her arch were closed as nearly as she had them as was possible for me to arrange them. Everything was replaced as I found it; then I hurried away, unspeakably grateful to the bird that would allow such fellowship on the part of a mortal.

Our unfamiliarity with the King Rail arises, not from the fact that it is so uncommon-the swamps are filled with them; but because they are extremely wild and almost never take wing, trusting to escape pursuit by flattening the feathers against the slender bodies and darting bet ween the reeds and rushes, where dogs can not penetrate or hunters shoot; hence the expression, "slim as a rail." 


\section{THE "QUEEN" RAIL}

Possibly I have made rarer studies of rarer birds, but into many of them there enters an element of pure luck, over which no control could be exercised. They were only obtained because I happened to be on the spot at the right moment, and so acquainted with the birds that I was able to snap, not for what they were doing, but for what experience had taught me they would do next. This picture was deliberate. I worked and planned for it. The bird was superb, while I did not spare myself in my efforts to gain her confidence. I drove those ninetyeight miles, and dragged my muck-laden feet by the hour through the chilly swamp-water, in the hope that I should get something nearly as good. I confess I never expected to do quite so well. This study of the "Queen" Rail to me represents the acme of what I have done with birds, in the way of winning their confidence, and becoming friends.

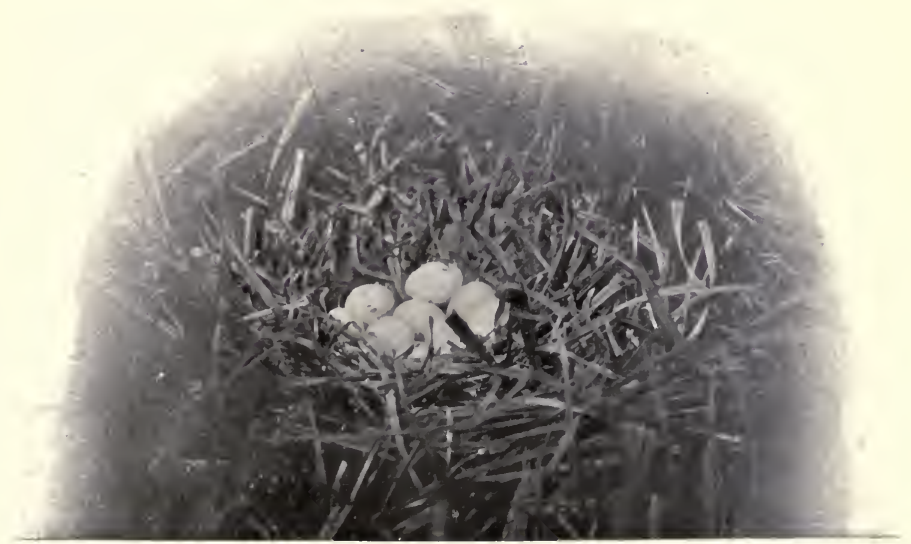

EGGS OF KING RAIL 
"His palace is in the brake

Where the rushes shine and shake;

His music is the murmur of the stream And that leaf rustle where lilies dream."

-Thompson. 



\section{CHAPTER III}

Gold Birds: Icterus Galbula

IN THE TREE-TOPS

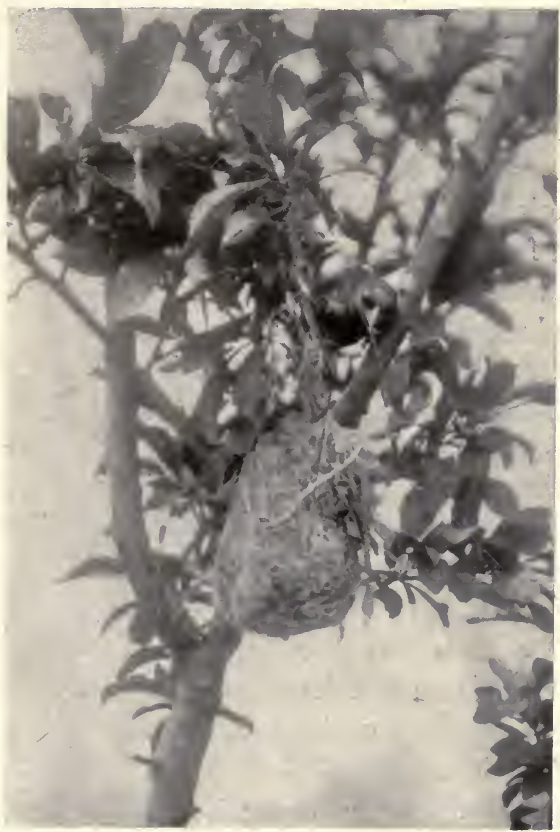

FEMALE FEEDING YOUNG

My FRIEndship with Orioles became intimate when I went one morning to carry a bit of sewing to a neighbour and found two starving, half-naked little birds, gâsping for breath, in full sunlight, on the board floor of a wire cage. To test his aim, with his rifle, the woman's husband had severed the small twigs, high in the air, from which the nest depended; both of them seemed very proud of the performance. In falling two of the birds were killed; the man carried home the nest to show what a "pretty shot," he had made, so as the woman had the old canary cage, she thought she might raise the two 


\section{FRIENDS IN FEATHERS}

living birds in the nest for pets. She knew she had failed with them, and soon they would be dead, for she greeted with joy my proposition to give her for the birds and cage what I had intended paying for the sewing, which I carried back to do myself.

First I put an egg and a potato of the same size to boil, while I cleaned the filth from the birds and fashioned for them a nest as nearly as possible like I thought the bottom of their woven purse would be. I used an old mitten, putting cotton in the bottom to absorb the excrement which I could not remore as the nests prove the parent Orioles do. Then I mashed the yolk of the egg, added a small amount of potato, moistened it with saliva, pried open the mouths of the half-dead birds and administered a small bite to each. They were not over a week old, but at the third feeding they opened their bills widely and cried the plaintive notes of baby Orioles when full fed and sleepy. We got along very well. The birds grew and became from the first the most lovable little feathered friends I ever had.

When they graduated from the nest, I put them in the cage. where they soon learned to feed themselves and use the perches. They had known nothing but the cage, they never made the slightest objections to it, and were so engaging and attractive that soon I invested in a big brass cage, the largest size made for Redbirds, which at that time were common captives. A friend begged so hard for one of them I gave her the old cage and the one I knew was a female; the male all of us petted constantly. The cage door stood open, so he had the freedom of the house, while if I went out to the trees to read or to sew, his cage, with the door closed, was carried with me.

I talked to him continually, spending more time with him than any bird I ever had in my own home. His coat began taking on its golden colour at a very early age; the black markings 



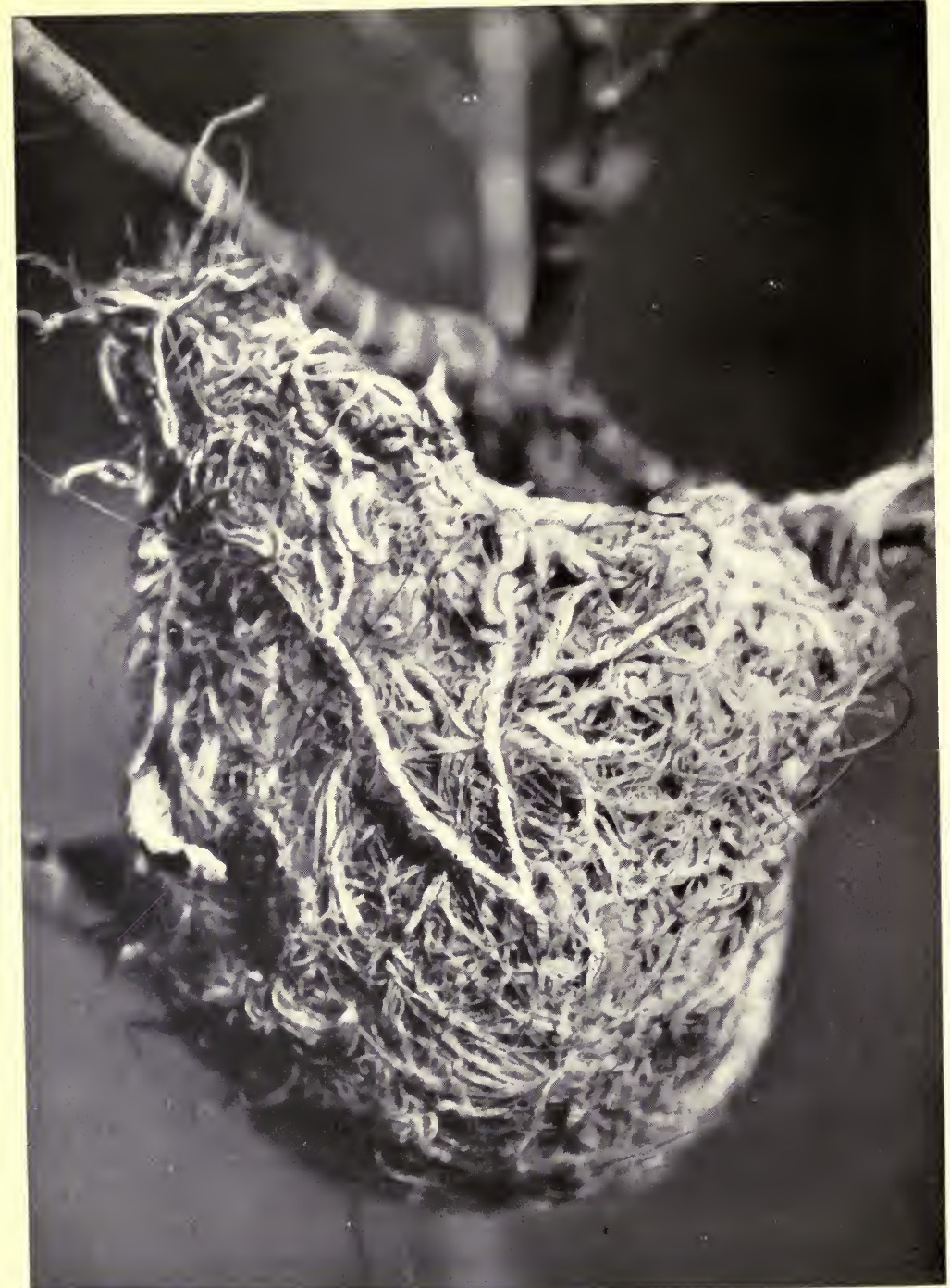




\section{GOLD BIRDS}

soon showed, while his beady black eyes were always watching me. As I sat reading or sewing in the house he hopped all over me, often sleeping on my head or shoulder. He entered and left his cage at will. He would play for an hour weaving bits of cotton cord or bright wool back and forth between the wires of the cage. He would hunt the sand of the cage floor for large pebbles which he would carry to the top perch, and leaning, drop into his bath to make the water splash. If I laughed and talked to him, he would do this repeatedly; if I said nothing and pretended not to notice, he would wait awhile, then try again. Once on entering the house I left the screen door open so long he darted from it sailing high in the sky with a burst of wild notes; so I thought him gone forever and stood helplessly gazing up at him; but presently he dropped lower and lower, then settled on my head and quietly I walked inside carrying him back to captivity. But the glad exultation of those notes on free wing kept coming back to me. They were not notes he sang in the house. That day I began definitely training him for freedom, lessening the food I prepared, instead bringing in branches with bugs, worms and lice, which .I taught him to hunt. When he could fly strongly, and live from food he found himself, in the spring of his second year I let him go, but missed him inexpressibly.

After securing my cameras and beginning professional field work among the birds, my first chance at an Oriole nest came while visiting my sister at Wabash. The nest was high in a maple in front of her residence, while not far from it stood a telegraph pole of size and height used to carry city wiring in the days before buried lines were compulsory. I hired her little son to climb the maple and tie back the intervening limbs, then I borrowed two ladders from painters working on an adjoining house, and lashed them together while the men set and fastened them against the telegraph pole for me.-Carrying a hammer and 


\section{FRIENDS IN FEATHERS}

big spikes I climbed the ladder to the top, and opposite the nest fastened up and focussed my camera. As I had to stand high in air, on the ladder placed perpendicularly, and reach around the pole to operate the camera, it was rather awkward work. The birds would not come to the nest with me on the ladder, so I attached a long hose, then sat under a tree in the lot to make the exposures, being compelled to climb the ladders at each, to reset the shutter and change the plate. In the meantime, afraid to watch me, my sister sat in a back room and prayed that I would not break my neck.

As the birds gain confidence in man, it appeals to me that Orioles are building a trifle lower. In more recent years, I have had opportunity to work around two nests from the top of a twelve-foot step ladder, by building up a few feet with boxes, so that the nests must have been close fifteen feet from earth. One nest was beautiful, built in the top branching of a small plum tree, on the A. P. Hardison farm, where I had permission to work among the birds as I chose; so I was free to lay down fences and drive into the orchard, there to spend days making friends with the birds. Mr. Hardison told me of the nest, and at my request set up a ladder where he thought I would want it, so that the birds had time to become accustomed to it before I added the box. I gave them a day with it, before beginning with the camera which disturbed them so little that twenty minutes after it was set up the female was coming before it for her regular feeding, then in a short time the male, who worked as assiduously as the mother bird.

The nest was the usual construction of plant fibre and lint having one piece of cotton cord hanging in a free loop across the front, but the end was woven in the top then carried many times around the largest limb, as was a white carpet rag, also. The other end had several pieces of cord, a long strip of cotton cloth 



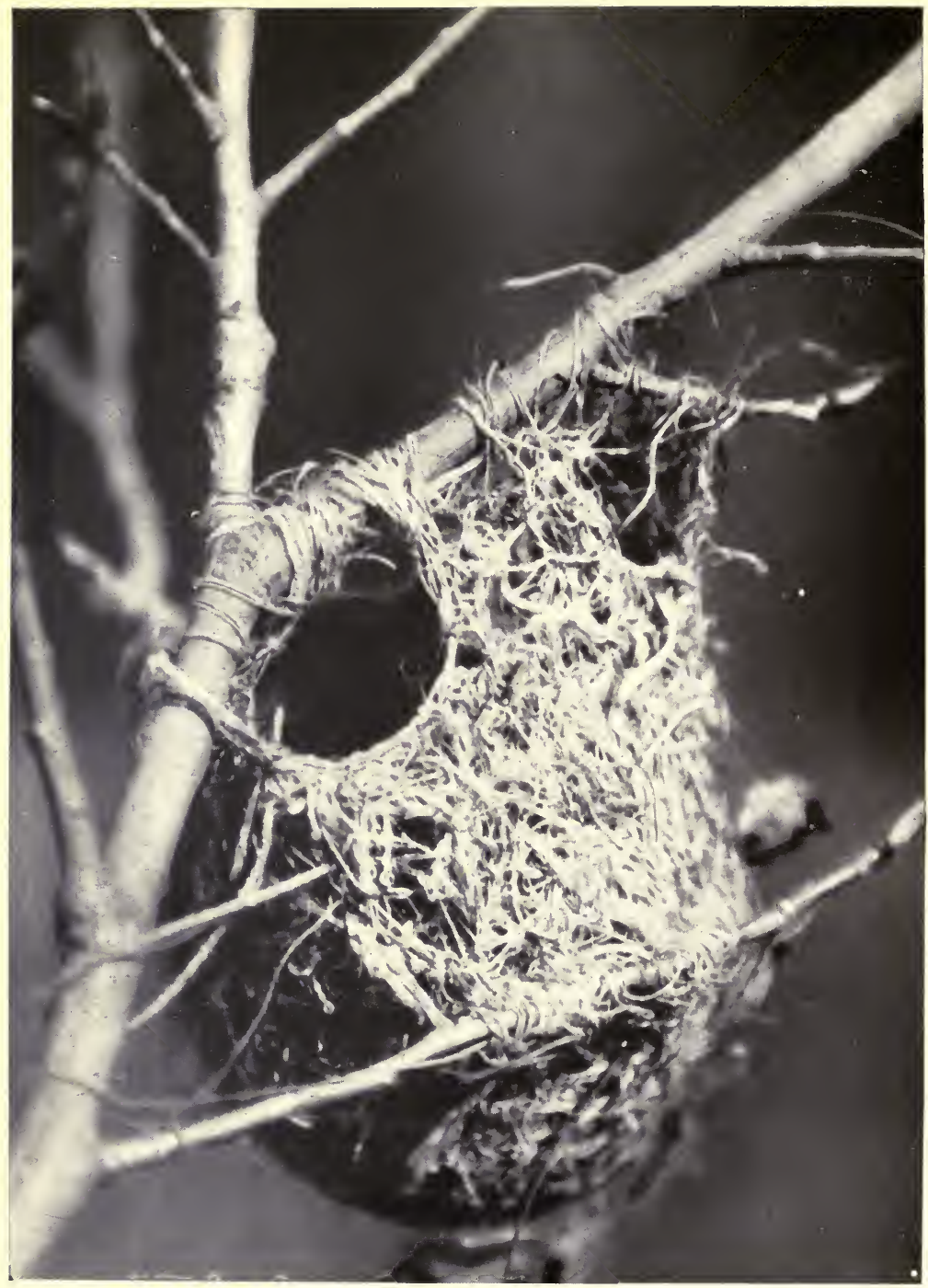

Reverse of same nest, showing fastening that holds it firmly; high window abandoned'and lower one eompleted and used by the brooding bird 
made fast to the twig and carried down around the top of the nest, the plant fibre being woven over it, then the end brought out and fastened to the tree. Only a cyclone that wrecked the tree could have destroyed that nest; I never have seen one more securely built; but all Oriole architecture must be very strong, as in a lifetime of field work I never have seen a nest destroyed $\mathrm{th} \mathrm{rough}$ faulty work on the part of the birds.

That there are tragedies among the birds, especially the $\mathrm{Orioles}$, is proved by finding the body of a male bird hanging from a loop of cotton cord, in a cottonwood, under a nest that had been abandoned, evidently

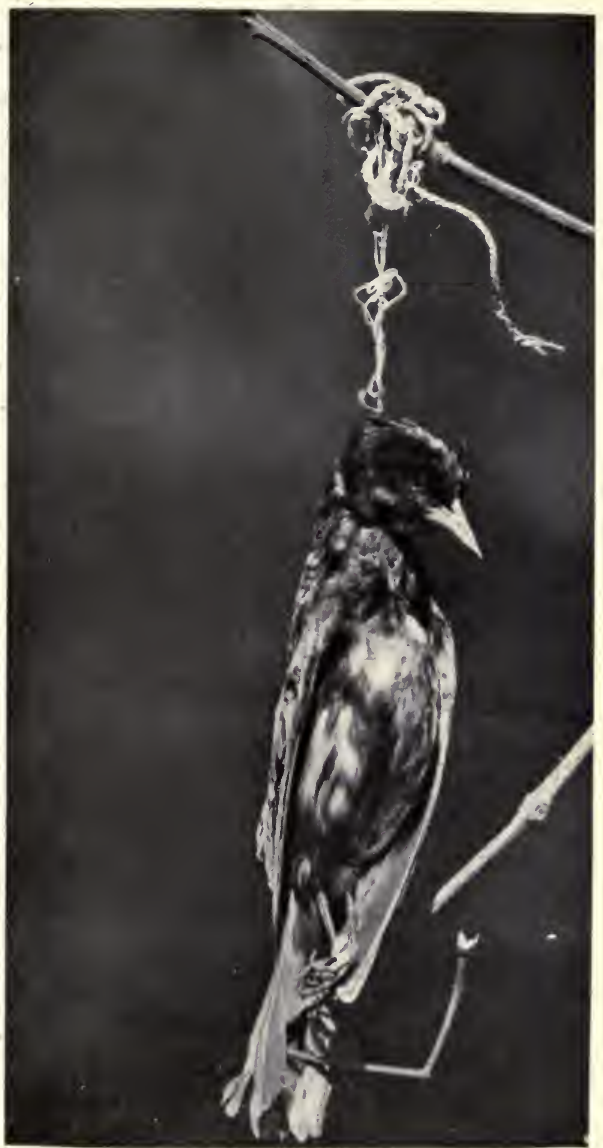

MALE ORIOLE THAT HANGED HIMSELF WHILE NEST BUILDING 


\section{FRIENDS IN FEATIIERS}

on account of the accident. One of the pair had dropped from above a piece of cord and heavy sewing cotton, intertwined. It had lodged on the point of a stiff dead twig, then been pushed back by the wind until it caught on tiny rough projections where a leaf had fallen. In working to free it, to use as a lashing to fasten his nest, the male had slipped a loop over his head, so when he pulled, it had proved to be a veritable slip noose, which drew tighter with his struggles, until he was choked. This is also proof that the male assists in nest building.

The young were hatched before I heard about the nest, but if I had known in time, I would not have tried to picture the eggs, as it cannot be done in so deep a nest without removing them, which is too dangerous. Once I took a peep into one of these low nests, which was a great treat. The eggs appear as if they had been imprinted with the lines of the nest in which they lie, being lined, traced and dabbled like brushwork, but the colour is delicate purple and brown. They are even more beautiful than the egg of the Kingbird.

The three sturdy young of this nest I began handling that first day, so by the time they were ready to fly they would sit for their pictures and return to the nest with never a protest. They took wing the day after this picture of them was taken, then I cut down their cradle for a trophy.

I had one later experience raising a young Oriole, too heavily bedraggled with mud and crude oil to move, that I found in a swamp. He was scarcely old enough to fly, so I fed him for a week until he could fend for himself before I gave him freedom. He loved water, splashing vigorously each morning, then making his toilet, then taking his breakfast from the point of a toothpick. I could have made exactly as endearing a pet of him as of my first Oriole, but I do not now believe in caged birds; while I had not the time to spare, so when he was self-supporting I released him. 



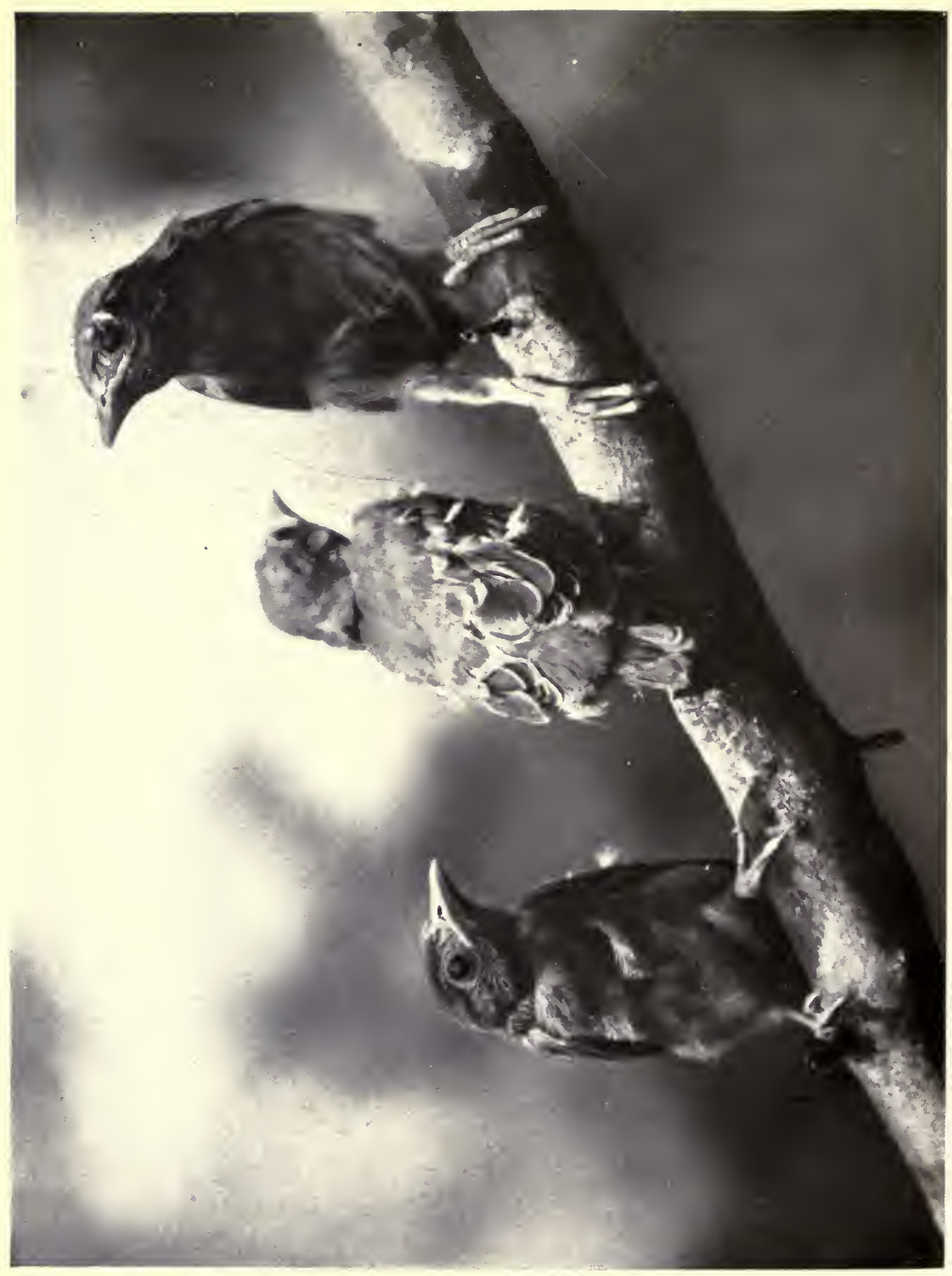




\section{GOLD BIRDS}

One Oriole nest of my experience differed from all others I ever have seen in two particulars, each of which indicated that its builders were progressive and had ideas. The nest was in a cottonwood, pendent as

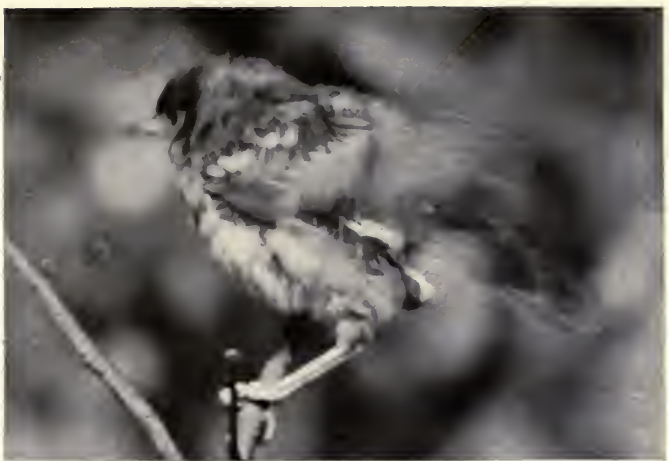

BATH usual, but not swinging free, for half-way down on one side it was firmly lashed to a stiff twig, the material so bound around and over it that the nest could not sway with the wind or bend under the weight of a Screech Owl attacking it, thus giving the brooding mother a far better chance to escape.

This nest also proved, as the front and reverse of it clearly

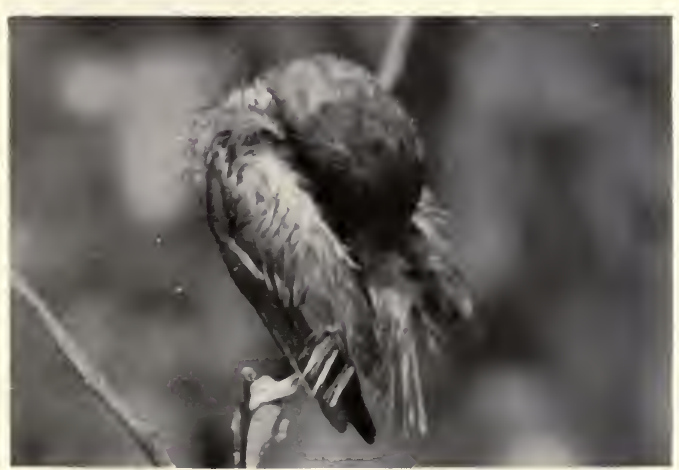

TOILET show, that it was a unique structure, most remarkable. The back was similar to all other nests, with its wide mouth for entrance and feeding. The front had not only the fastening described, but two 


\section{FRIENDS IN FEATHERS}

attempts at a window. The first on the right, rudimentary, had proved to be so high that it could not be used, so it had been abandoned. The next attempt was so low that the brooding bird could sit on her eggs, put her head from the window and watch the neighbours. It was clearly defined, firmly outlined and deliberately woren as a part of the nest. It was also large enough that in case of attack from Owls or squirrels at the top, the mother bird could slip from the window. I watched her brooding and feeding. After figuring out what she had done, I had a boy climb for the abandoned nest, which proves exactly what I write of it. It also shows that these birds were in advance of their time and knew what they were doing. By no possibility could they have constructed this nest as it is without knowing why they did it. They fashioned this window to enable the mother to have light and air, also to watch her bird neighbours while she brooded. I, and many other people, saw her so use it during that time.

In much personal experience with these birds I know them to have fine dispositions, almost never cuarrelling or meddling in the affairs of other birds. They are invaluable insecticides, searching under and upper sides of leaves as well as bark for their chosen food; great blessings to any orchard. They are a treat in appearance, our bird of purest gold, and their notes sown copiously on air are as golden as their backs. Their music is almost irritating, in that they start a lovely theme, see a bug on a blossom and stop to catch it, forgetting to complete the song, although at times they do finish after a long interval. Sometimes one hears the end, but not the beginning of the strain. Many musicians have put these songs on record as they appeal to their sense of harmony and composition, one has even caught that Oriole theme which occurs in the Spinning Song in "Martha": 


\section{GOLD BIRDS}

"I can wash, sir, I can spin, sir,

I can sew, and mend, and babies tend."

But there is no one to tell us whether the bird copied the master, or the reverse. Probably the strain is original with both, since the Oriole of the continent, which Von Flowtow probably would have heard, is in a family distinct from Icteridæ to which our Orioles belong.

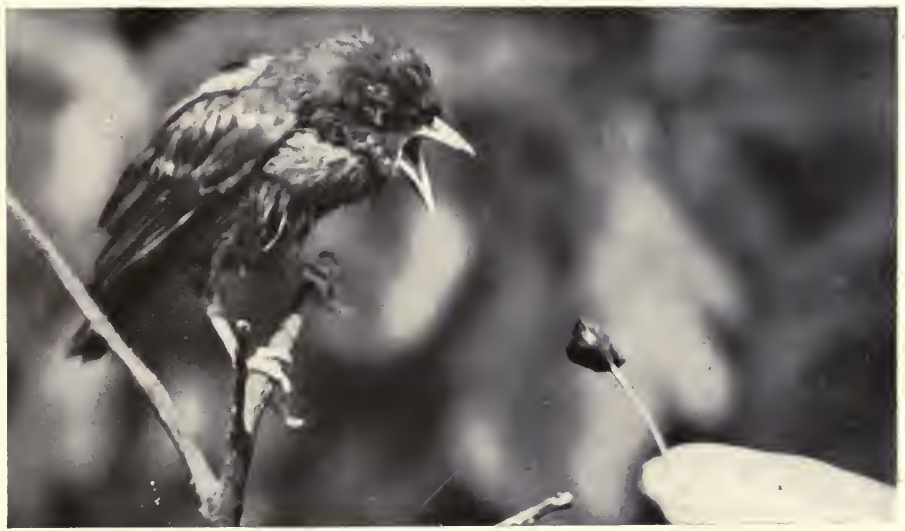

BREAKFAST 
Grey woven hammock, a swaying berth, Tossed by the winds the whole night long, Nothing more precious than you on earth, For you are the cradle of song.

Bright flying wings, fresh sun-bathed each hour, Clear bubbling song, from golden throat, Oh the wonder, that you have power,

To make June more glad with your gay note! 



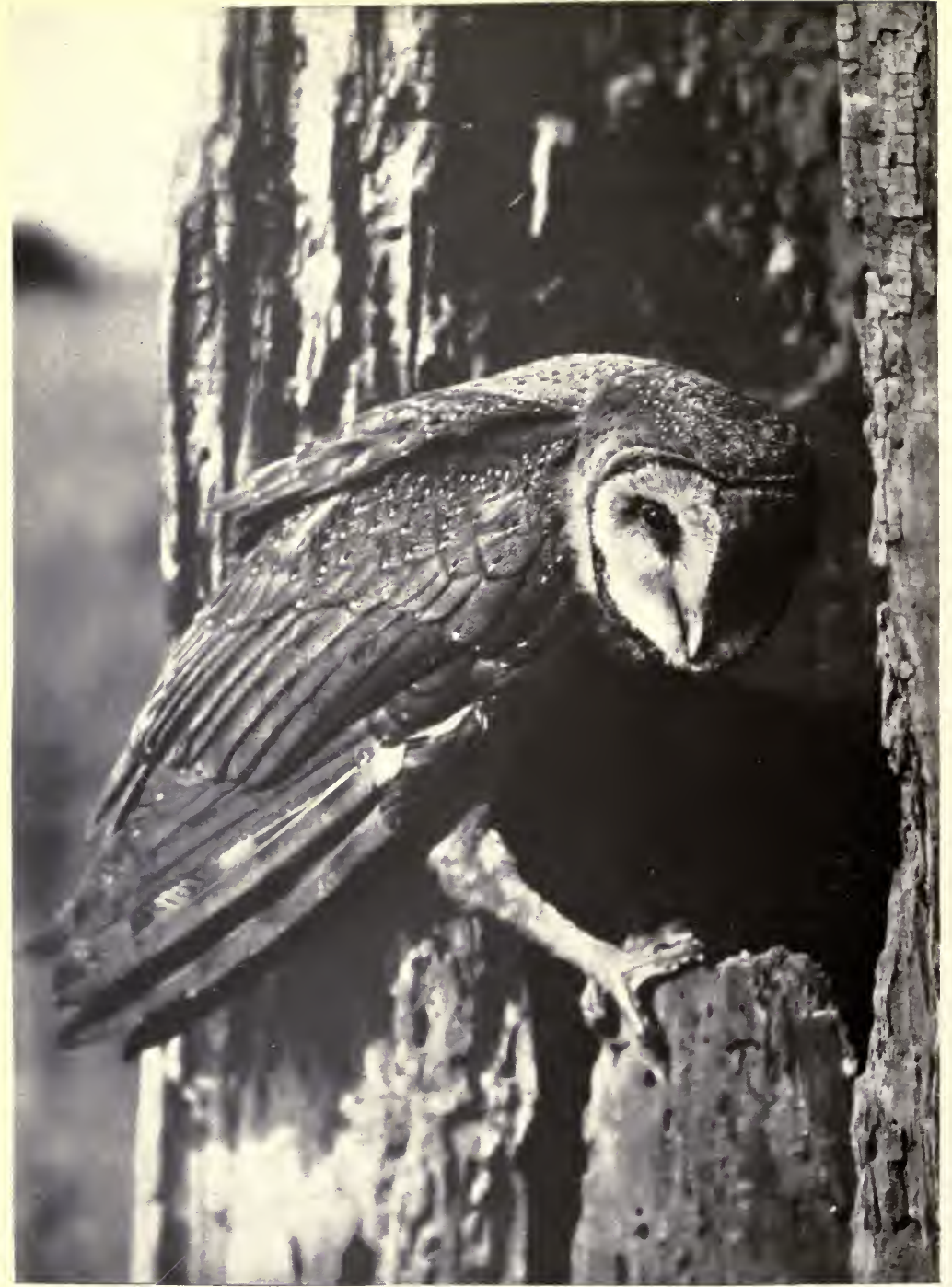

BARN OWL 


\section{CHAPTER IV \\ "The Barn Owl: Strix Pratincola}

\section{IN DEEP FOREST}

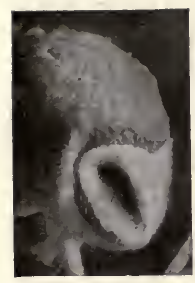

HEAD OF BARN OWL

DiD you ever traverse the Michigan Inland Route, before fire annihilated and lumbermen despoiled its great beauty? There was charm in every foot of that dark, marshy old Northern forest, in the narrow river flowing swiftly over its bed of golden sand, in the rushy, moss-covered swamps which bordered it, and in the clear, cool air perfumed with dank odours and the resin of pines.

Forests of spruce, cedar and birch locked branches across the river, among them monster trees had died and lodged at every conceivable angle in falling; the swamp on either hand was scarlet with foxfire, whilecuriousferns, mosses, orchids and lilies lined each bank. All its length were places where deer had been to browse and drink, clumsy bears to eat berries, fish in shallow pools and play havoe with the housekeeping of muskrat and beaver. Fancy peopled these spots with dusky-painted faces, while one could almost hear the water-dripping paddle-blades and the twang of the bow-string.

We were unusually early that year, and extremely fortunate in securing a guide who was an ardent sportsman and a lover of all wild life. Of course I was more interested than he in securing subjects for my camera, but a casual observer scarcely would 


\section{FRIENDS IN FEATHERS}

have guessed it. My window on the second floor of our stoppingplace overlooked the tree-tops and gave me a view of a wide stretch of the lake, the river creeping away in the distance, the gleaming trunks of birch and spiral tops of cedars lifting above an impenetrable tangle of interlocking trees and bushes.

Every morning a large Eagle with a golden head, either fishing or preying on water birds, hung above the lake, and lıw my guide and I did hunt for the nest of that bird! We never found it, but in our search we located, in a big hollow tree behind our hotel, a family that repaid our disappointment. If you never saw Strix pratincola in her chosen location, busy keeping house, then you have missed one of the rarest sights of birdland. We named her "Monkey-face," buffoon that she was, the minute we caught sight of her, blinkingly peering from her front door to learn if it were too early to go hunting and sadly shaking her low-hung head, as if all the woes of birdland rested heavily on her shoulders. IJer face was heart-shaped, sharply outlined with several rows of crisp up-standing brown feathers and covered with white feathers lightly tinged with the pale ash and lavender which proved her a last year's bird. Ifer eyes were small, for an Owl, and slightly oblong. Her beak and mouth were almost hidden with long silky down. Her breast was paler than her face and touched here and there with tiny black feathers. On the top of her head began a beautiful light tan colour that took on strength as it spread over her back, wings and tail. A-top her head and across her shoulders she was thickly sprinkled with tiny black feathers tipped with white. Her primaries and secondaries were lightly barred with brown, but her tertiary and shoulder feathers were solid tan, while each seemed to end with this peculiar tipping of hlack and white. She had four strong toes, and her legs were bare to the first joint. Iater we saw her mate, and he closely resembled her. All the difference we could 



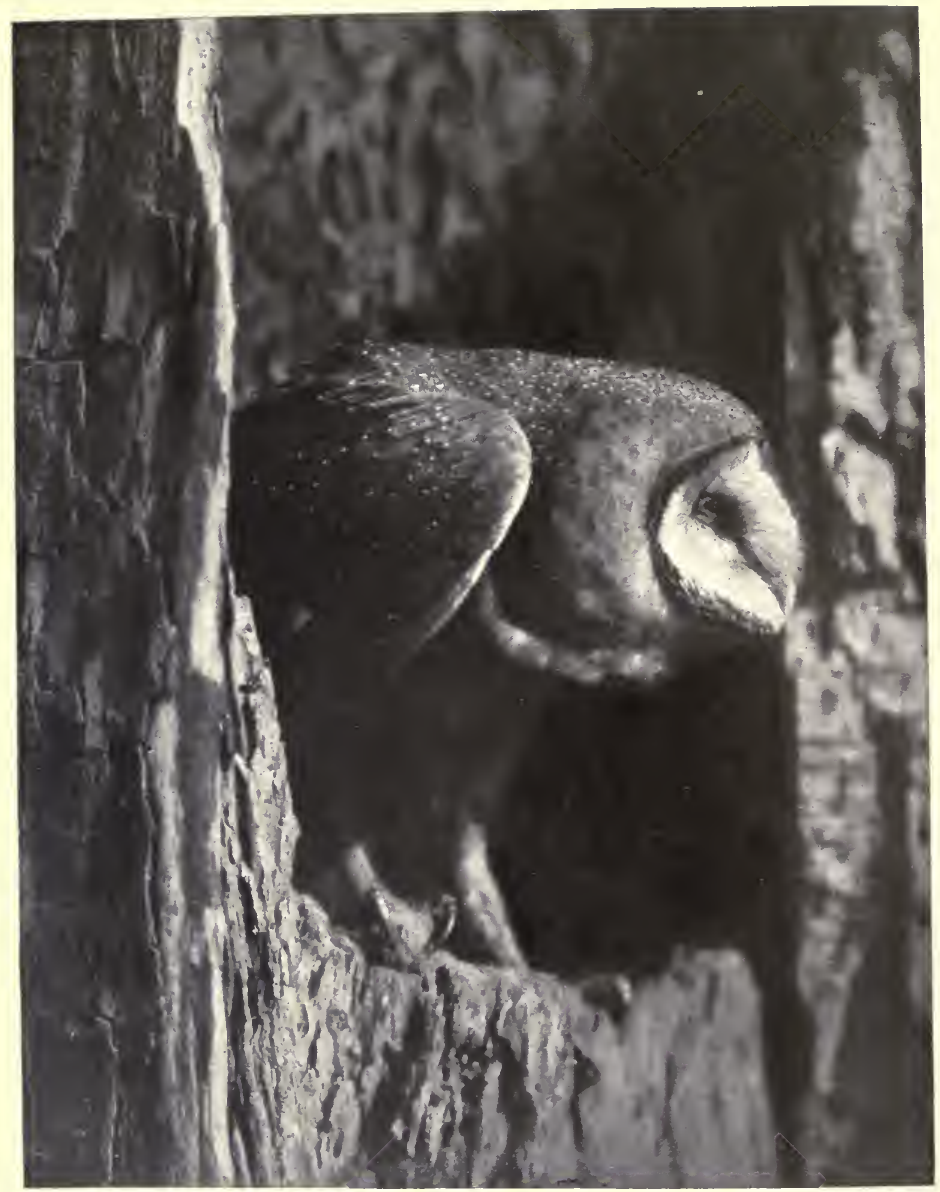

BARN OWL

"Blinkingly peering from her front door to learn if it were too early to go hunting" 


\section{THE BARN OWL}

note was that his face and breast were snowy white, with the same markings, while his shade of tan seemed a degree lighter. Crouching where we had been standing we watched and waited. Soon with the soft, uncanny flight of an Owl, she swept over us and away into the deep dark forest.

Investigation proved that the tree contained Owl babies, how many could not be told, but ornithologists allot to this species from three to five. They also place this bird's northern limit on a line with Rhode Island and its habitat in the South and on the coast; yet here was a true Strix pratincola in northern Michigan, almost a full degree above this Owl's northern limit and certainly central.

It would be the easiest thing in the world to measure the depth of that opening and remove a section from the back of the tree that would allow pictures of the young to be taken, but how was one ever to secure a camera-shot at the old ones? That was our problem. We decided to try to solve it before touching the tree to work on the babies.

The following evening we were at the tree in time to see the Mother Owl leave it in search of food. The opening was large. We had been as noiseless as possible and concealed ourselves so well that she stood, to accustom her eyes to the light, for a length of time that would have given a fine exposure, had there been a camera on her level.

Fortunately the opening faced the east. Trees and branches could soon be cut away to get direct light, while there was another tree close, to the trunk of which a camera could be attached directly opposite the entrance. A day of hard work followed. Cleats were sawed and nailed to this tree so that we could walk up and down it like a ladder, and opposite the Owl's door was fastened a small platform on which we placed the camera and focussed it on the opening. It was useless to talk of snap shots in that light, so the shutter was set at half a second on a medium 


\section{FRIENDS IN FEATHERS}

plate, the long hose attached and the camera covered with bark. It so closely resembled a huge knot on a tree that no bird, even with the keenest eyes, would have paid the least attention to it.

Then we waited until black night, but no birds either came to or left the tree. We attributed this fact to the noise and disturbance we had made, although work was done as swiftly and quietly as possible; but there had been much to do, and several trees in our way could not be felled without the inevitable crash. We decided to risk leaving the camera as it was and did not go near it again until five o'clock the following evening. Near six, Mother Owl stood in her doorway, blinked her eyes, yawned, hung her head and slowly and sadly shook it back and forth as if life had no attraction for her.

Kneeling up in my anxiety, to see better through the underbrush, I snapped a twig. Mother Owl peered in my direction, listening intently, every muscle on the alert. Oh, but I was thankful for a well-oiled shutter! It might have been set at a second, for fully that length of time elapsed before she dropped her head again and shook it more depressedly than before. Then her body seemed to lift suddenly and she was gone.

"Oh, why didn't I set that shutter for a second?" I groaned. "She never moved in that length of time."

"To-morrow night we will," said my guide, encouragingly.

Then we went to derelop the plate. We really had Mother Owl so that the plate could be intensified into a printable one, but it greatly lacked my idea of what could be done with this subject. The following night we tried again. We set the shutter at a second. Mother Owl flew in the middle of the exposure, which taught me that I should have used the bulb, as the impulse to flight was detected in time to have closed the shutter if it could have been done. That plate was spoiled.

Then I conceived a brilliant idea. Why not close Mother 


\section{THE BARN OWL}

Owl's door after she left at night, and keep her out until the light was sufficiently strong to take her picture in the morning? She was feeding her young, and they would be very hungry, but not particularly hurt by a slightly longer fast than usual, while no doubt they would cry for food and keep her close. When she found she could not reach them she would remain near and then, if they would cry, there was every probability that she would fly to them, even in a fairly strong light.

That day my lenses were polished like diamonds, a fresh medium plate placed in the camera, the shutter set at a bulb exposure and everything tested to see that it worked smoothly. When Mother Owl left that night, we discussed giving her until midnight to bring several rounds of food to the babies, but dared not risk it. If the Owlets were not very hungry they would not cry, and if they did not, it was almost sure their mother would not try to fly by day.

A board was nailed securely over the opening. Mother Owl returned and attacked it beak and claw. Soon her mate came, and how the two of them worked! It was almost too bad. I fancied I could see Mother Owl shaking her head when she really had some reason to shake it. My heart failed me. This was not living up to my pact. It was not treating that mother as I would be treated. I whispered to the guide to go and take away the board. It is a good thing that he was made of a little sterner stuff, for he pointed out that the young were half grown, that there was nothing happening to injure them permanently, that they were birds of prey, and that if they did not want their pictures taken they had no business to carry around such faces to tempt us.

At times they would leave. Then they would return, sometimes together, sometimes singly, and work to pull the board away. The night was clear, cool and filled with sounds. The guide repeatedly assured me that there were no snakes, while I had seen none. Often we heard the crashing of deer, or at times 


\section{FRIENDS IN FEATHERS}

the heavier passing of bear, but the guide said they were only small black fellows and if we should meet, they would be worse scared than we. Also, he had a rifle and each of us good revolvers.

With the dawn both birds gave up the struggle and flew away, but from their calls to each other we knew that they were very close. Near six o'clock, when the good old red sun fell fairly on the opening. I nodded to the guide. Quietly as possible he slipped to the tree, climbed it and removed the board. Then he dropped inside the opening a piece of string, weighted with fresh beefsteak and a stone. As soon as he returned and everything had been still for a time, he lowered the meat; then the young Owls set up a perfect clamour. I was kneeling, watching and listening with all my soul. The night had been cold, but I was wet with perspiration. The flight of Mother Owl was noiseless, but I felt her coming and signalled the guide to jerk away the meat. The string broke and the meat fell inside. She alighted with a slow sweep and as she struck, behind her I did my very best at an imitation of her babies' cry that I had been softly practising over in my throat all the night.

Instantly she paused, turned to my direction, surely for a full second, opened her eyes unusually wide to intensify her vision, then she was gone. Save for a small feather she had slightly disarranged on one wing while working at the board, she seemed to me absolutely perfect.

"What makes you so white?" asked the guide, as I stared at him wildly.

"I forgot to squeeze the bulb," I sobbed, breaking down entirely, after the long strain.

"You squeezed it until your finger-nails were white," he said; "I was watching you."

"I am sure that I didn't," I urged, in the hope that he would say something in contradiction that would help me to remember. 


\section{THE BARN OWL}

"But you did," he said positively. "IIaving to tell me when to pull, trying to imitate the babies and work the bulb all at once made so much you don't remember. Can't vou tell from the camera whether you did?"

"Why, of course!" I cried joyously. "Take it down at once; and, dear boy, were you ever careful?"

I vow his eyes were wet as he answered, "Several times lately. You look the other way. It shall come down like a box of eggs," and it did, with the shutter closed.

My hands shook as I pushed the slide into the plate-holder, and withdrawing the holder, wrapped it in a sheet of rubber. Before eating or sleeping, I carried that plate to my boardinghouse and developed it, with the guide peering over my shoulder. It was breathless work.

"Are you sure that stuff is all right?" he asked as the chemicals were measured in the beginning. A minute later: "Can you see anything yet?" Then: "Would it hurt just to take a peep now? She ought to be out enough that you can see if she really is coming." When I first held the dripping plate to the ruby lamp he shouted: "Hello, old monkey-faced moon-eye! I knew we had you! Stopped to look back, didn't you? And just see what we got! Ginger! Ain't she a bird? Yessir! That's the way she looked, just exact!"

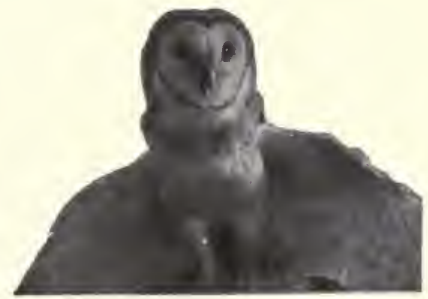

THE FACE A PERFECT HEART-SHAPE

69 
"Mourn not for the Owl, nor his gloomy plight!

The Owl hath his share of good:

If a prisoner he be in the broad daylight,

$\mathrm{He}$ is lord in the dark greenwood!

We know not alway

Who are kings by day,

But the king of the night is the bold brown Owl."

-Barry Cornwall. 



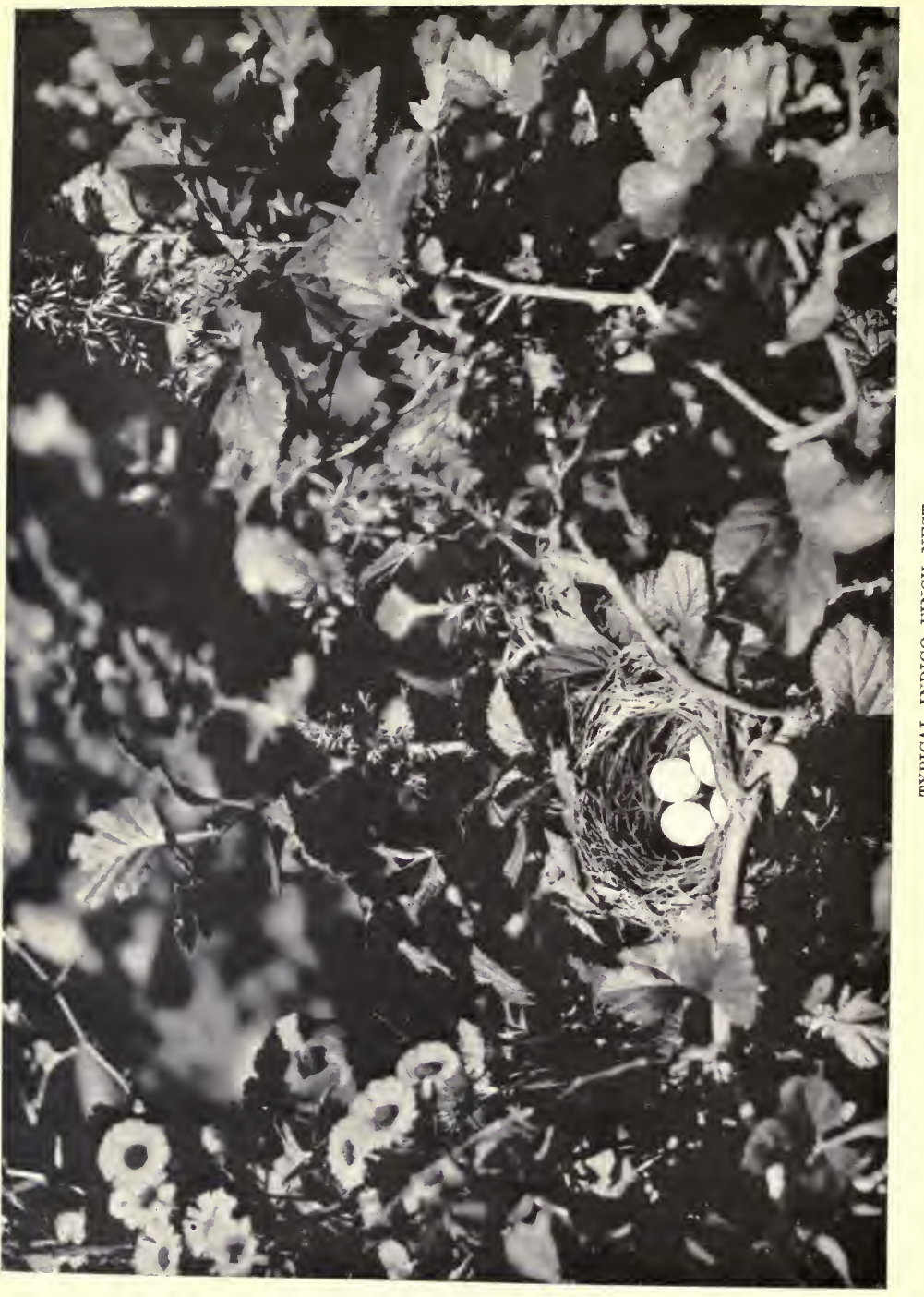




\section{CHAPTER V}

Indigo Bluebird: Passerína Cyanea

IN SHRUBS

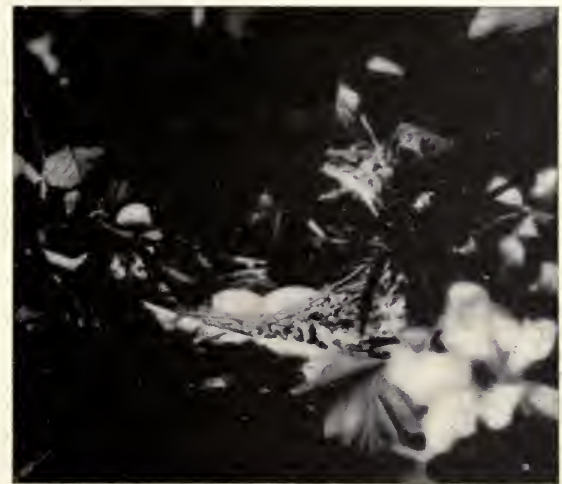

NEST OF INDIGO FINCH

The Indigo birds came to the Cabin to nest. While working in the garden one spring the Deacon and I were attracted by the fluttering and calling from a birdhouse containing nineteen yellow Canaries and green Linnets, in the conservatory. On the outside sill, beating against the glass in a vain attempt to enter, was a male Indigo bird. Evidently the flowers and shrubs seemed fine to him for he wanted to join the other birds chattering among them. After trying for nearly an hour he returned to his mate who had been watehing him while prospecting among a row of roses and shrubs screening an alley wall. On the wall they talked it over. They approved of that row of greenery quite as much as we did, for the same forenoon they began building among the scraggy branches of a bush honeysuckle.

The bush stood where I had full view of it from the back door and steps, also from the conservatory, so that I had fine opportunity to observe their nest making. The male did not sing to 


\section{FRIENDS IN FEATHERS}

the female while she worked. He did sing some, but the greater part of his time was spent carrying dry grass and tiny weed stalks of which the nest was built; he even entered it and placed his offerings himself, without protest from the female.

She was a grayish brown, but he was a gorgeous glinting blue, deep to purplish in the strongest shades, gleaming almost silvery white in the highest lights on his sleek head and neck, black feathers in his wings and tail. He made an exquisite picture when he alighted on the honeysuckle among the waxy leaves and yellowish red bloom, or perched above on the wall singing snatches as he worked. When he made a business of music he selected the topmost twig of the tallest tree on the west of the Cabin, pouring out a reckless abandon of song that lacked the melody, yet in a way reminded me of the Canaries of the birdhouse. He always began with a flourish of downward grace notes then raised clear and strong above the ordinary piano keyboard in notes rising and falling, then a level group of three, a drop and three more, then back to the beginning. He could repeat this full strain several times to the minute, while lre sang it almost uninterruptedly for an hour in the morning and sometimes for nearly two in the evening, from five to seven. This musical demonstration drove the Canaries almost crazy, so a dozen at a time they lifted their voices and tried to drown his notes, but after a few days he mounted his twig on the cut-leaved birch closest his nest and sang in an ecstasy of oblivion to everything save the swelling emotions of his own tiny heart. Such outpourings of song I had never before heard. I am sure he sang his strain over with slight change a thousand times a day.

When he was not singing, after the nest was completed, he worked for us in a double capacity. He hunted tiny worms and beetles, then searched any last year's dead stalks he could find for seed; from his industry, he must have made a high record both 
- 


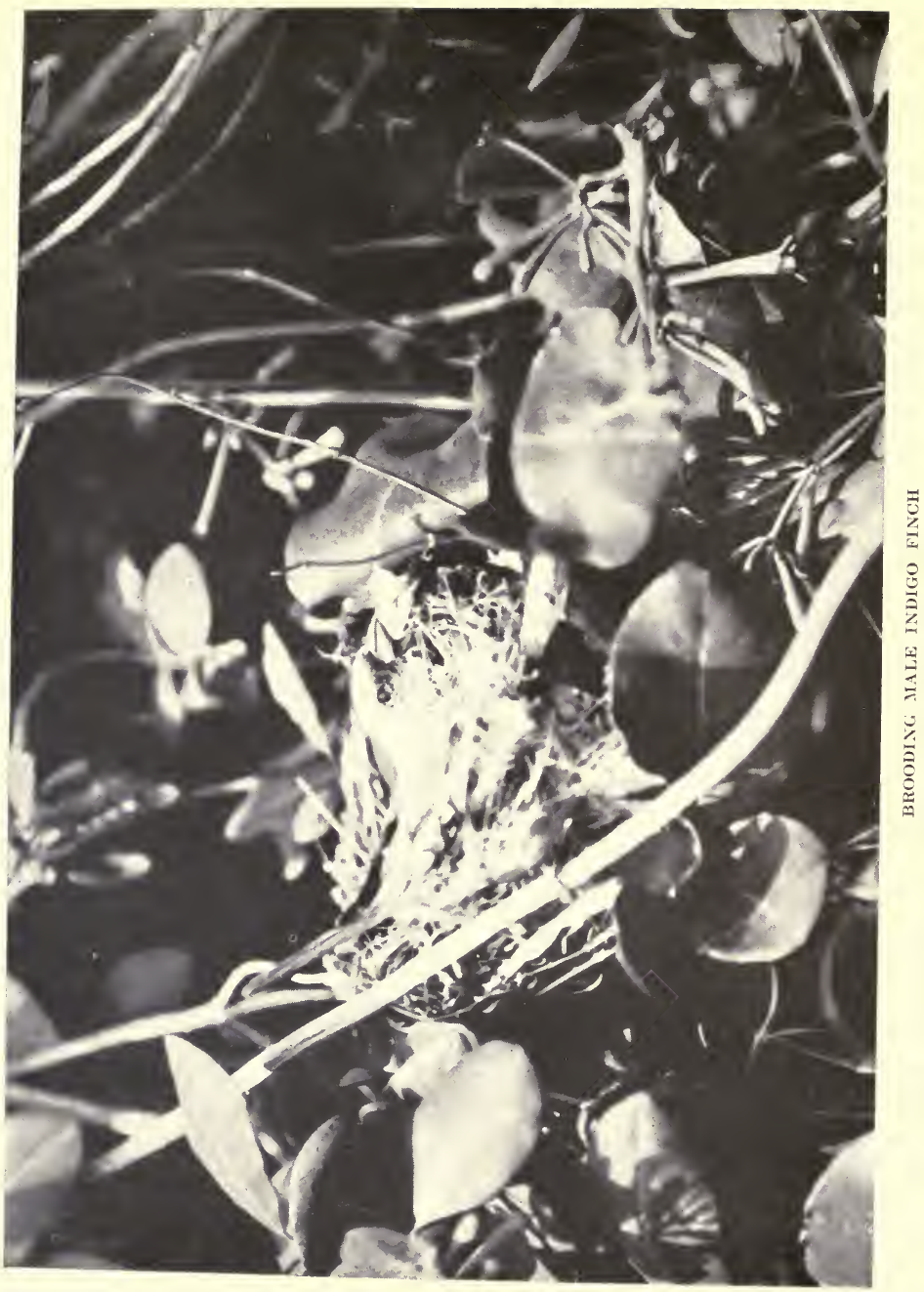




\section{INDIGO BLUEBIRD}

on worms and weeds. He was an invaluable member of our family for his music and his industry, while he endeared himself to all of us by his tender and unceasing attentions to his mate. He helped more than any bird I ever have watched in nest building, while from the first he always entered the nest to brood when the hen went after her morning food and exercise. As she left the bush she uttered a sharp call that sounded like: "Sir, sir!" Heinstantly responded and hurrying to the bush entered the nest and remained until she returned.

From the first day, I began making friends with them, gradually introducing a tripod, then a camera, then myself, into their immediate surroundings. When they had brooded a week I secured a charming study of the male bird while the light was full in the east and he at his daily stunt of brooding. In years of field work I think this is the only study I have of a brooding male bird. I have many of a male on the edge of a nest, feeding the female or young, but only this one of a male really settled in a nest, with the patient, absorbed look of the nesting female on his face. Mentioning his face recalls that it was dark on his cheeks close around the beak, while there was a tiny speck of a foreign growth in the inside corner of one eye, where he probably had flown against a thorn in a former nesting, for he was a bird of too much experience not to have nested before; also, as a rule, all the Indigo bird nests I have seen are in thorny bushes like hawthorn or crab, where it is a wonder that more of the birds do not injure themselves.

After developing this plate I decided to try for one more, in the hope that the bird in brooding the following morning would turn his "good" side to the camera, so that I could secure a better study of him, and then begin on his nest and eggs. Some time that night a neighbour's cat stole across the alley, destroyed the nest and judging by the feathers, ate the female, leaving the male 


\section{FRIENDS IN FEATHERS}

fluttering disconsolately around the location. I dislike cats more than any snake I ever saw. A few days later, having heard my lamentations about this nest, Bob found one for me in a small haw bush on his lease.

This pair was brooding for the first time and wild as any birds I ever saw. There was no hope of a study of the grown birds without a long preliminary training, and small chance for it at that, so for the sake of the series I made a study of this nest at once. A mystifying thing about it was that the birds building for the first time made a neater, more compact nest than those of previous experience. Nothing was used in it save dry grass of a fine variety. The four eggs were similar to all I ever have seen, snow white, although some naturalists report eggs of a bluish white and one responsible man has seen at least one nest having speckled eggs.

I never succeeded in getting either of this pair before the camera, probably because I had a triumph in the picture of the brooding male, so I did not try as I would have done if I had secured no Indigo pictures at all. The young of this nest were stodgr little fellows coloured much like the mother and always stuffed almost to the bursting point. If I were asked to prove the value of the Indigo bluebird as an exterminator of insects and weed seeds, I should unhesitatingly offer this study of the four young from a nest which I visited often, for each trip found them always in the same plethoric state, while the elders seemed sleek and well fed also. The reason only three show in the picture is that the baby moved to the left until he was bisected.

In going back and forth to Bob's lease for these Indigo Finch studies, I noticerl each evening on the home-way, that a Finch sang on a telephone wire beside the levee, at the west end of the river bridge. I hunted for his nest among the tangle of small 


\section{INDIGO BLUEBIRD}

bushes on each side of the road; Bob joined in tne search several times, but we never found it.

This male sang quite as uninterruptedly and even more musically than my male of the Cabin birch. He was there every morning and evening, being so tame that he did not take flight at the passing of car or carriage close beneath him. I told MollyCotton about him. For the greater part of that Summer she could take friends to hear his concert and never be disappointed by his failure to sing; while at sunset, if he chanced to turn his gaudy back to the bright light of the West, the blue became so intense it seemed almost silver, adding a high and lovely colournote to his performance. In consideration of the tenacity with which he clung to the wire for so many weeks, he must have brought off more than one brood in that location. Combining his seed and insect consumption with his beauty and song, he becomes one of our most precious birds.

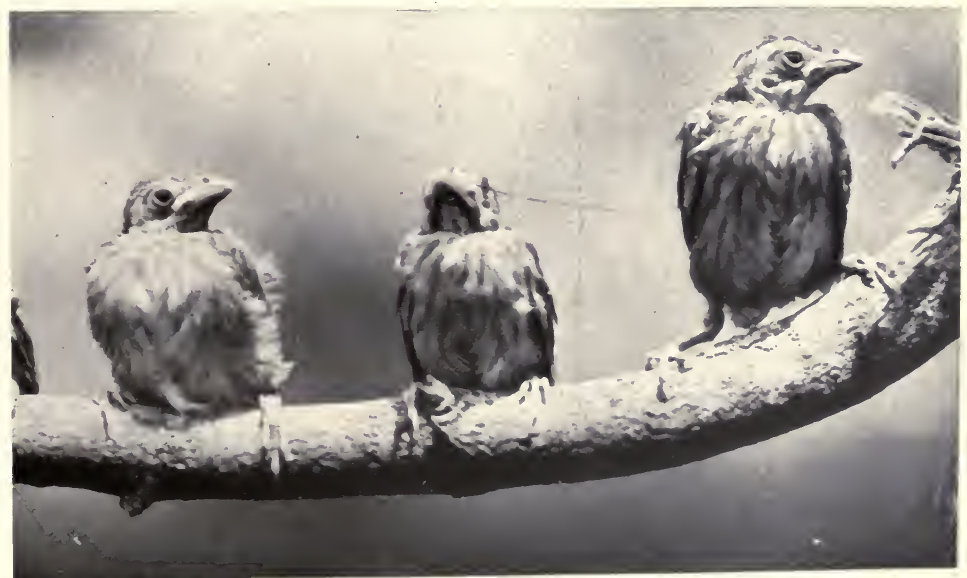

STUFFED BIRDS 
The Cardinal ate cochineal until he turned red. In fighting, the Wood-pecker bloodied his head. The Oriole was such a gay, roving fellow, He flew in the sun until he burned yellow.

The Brown Thrasher got his brown, bright and ruddy, Because he once fell into a brown study.

While the Indigo Bird turned his brilliant hue, When he bathed in a tub of rinse-water blue. 



\section{CHAPTER VI}

\section{The Wood Thrush: IIylocíchla Mustelina}

\section{IN THE VALLEY OF THF WOOD ROBIN}

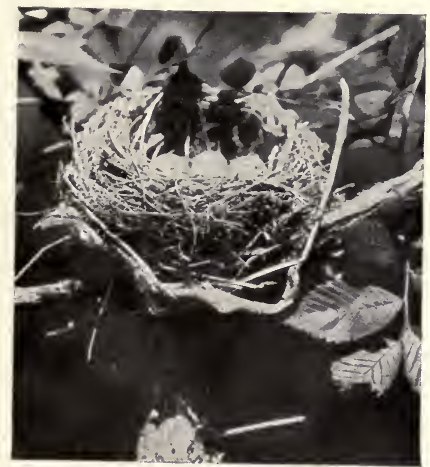

NEST OF WOOD ROBIN, SHOWING USE OF CAST SNAKE SKIN

I AM always happy to learn the location of a pair of birds by any method, but it is pure delight to find a nest myself. For a week, on coming from field work in the evening, when crossing the levee that bridges the valley lying between the Wabash and the outlet of the Limberlost, I heard a Wood Thrush or Bell Bird singing the ecstatic passinn song of mating time.

The embankment was fifteen feet high. On either side of it lay patches of swamp which grew giant forest trees and almost impenetrable thickets of underbrush. There were masses of dogwood, hawthorn, wild plum, ironwood and wild rose bushes growing beneath the big trees; grape-vines, trumpet creeper and wild ivy clambered everywhere, while the ground was covered with violets, anemones, spring beauties, cowslips, and many varieties of mosses and ferns. The place was so damp, dark and cool that the cowslips were paler than is their wont, while the violets grew stems a foot in length. A small creek wound a 


\section{FRIENDS IN FEATHERS}

devious course through the valley and there were many pools that lay filled throughout the summer.

In all the surrounding eountry, here was the one spot exactly filling the requirements of an ideal location for Wood Thrushes; so when those notes of bell-toned sweetness sounded, evening after evening, from the same tree, it was evident that somewhere in the shrubs beneath that divine singer there brooded a bright-eyed brown-coated mate to whom he was pouring out his heart in notes of tenderness and cheer.

The following morning, starting an hour earlier than usual and hitching my little black horse to a telephone pole on the levee, I climbed down the embankment. My way in the thicket could be made only by stooping beneath the branches, creeping between bushes, and sometimes using my hatchet. My feet sank deep into the damp muek beneath the thick layer of dead leaves; there were many small pools to avoid and onee my course changed entirely, because a great flood of a few months previous had filled the whole valley with one broad, raging torrent that overwashed the levee. Lodged in underbrush were a drowned eow and some pigs.

When the tree from which my bird had sung was located, I began searching around it, in an ever-widening circle, for the nest. The first thing I found was a big carp, firmly impaled at the height of my head on a thorn tree and dry as any herringanother result of the flood. My next trophy was the nest of a pair of Rose-breasted Grosbeaks, which defied the rules of naturalists, beeause they did not build in a wild grape-vine, where grapevines were plentiful, nor did they build of last year's dried grapefeelers, but of sticks and twigs. Then I found the largest Cecropia cocoon of my experience; in a few weeks there would emerge from it a beautiful moth; but that was so high above my head it eould not be secured that morning. I cut it a week later 



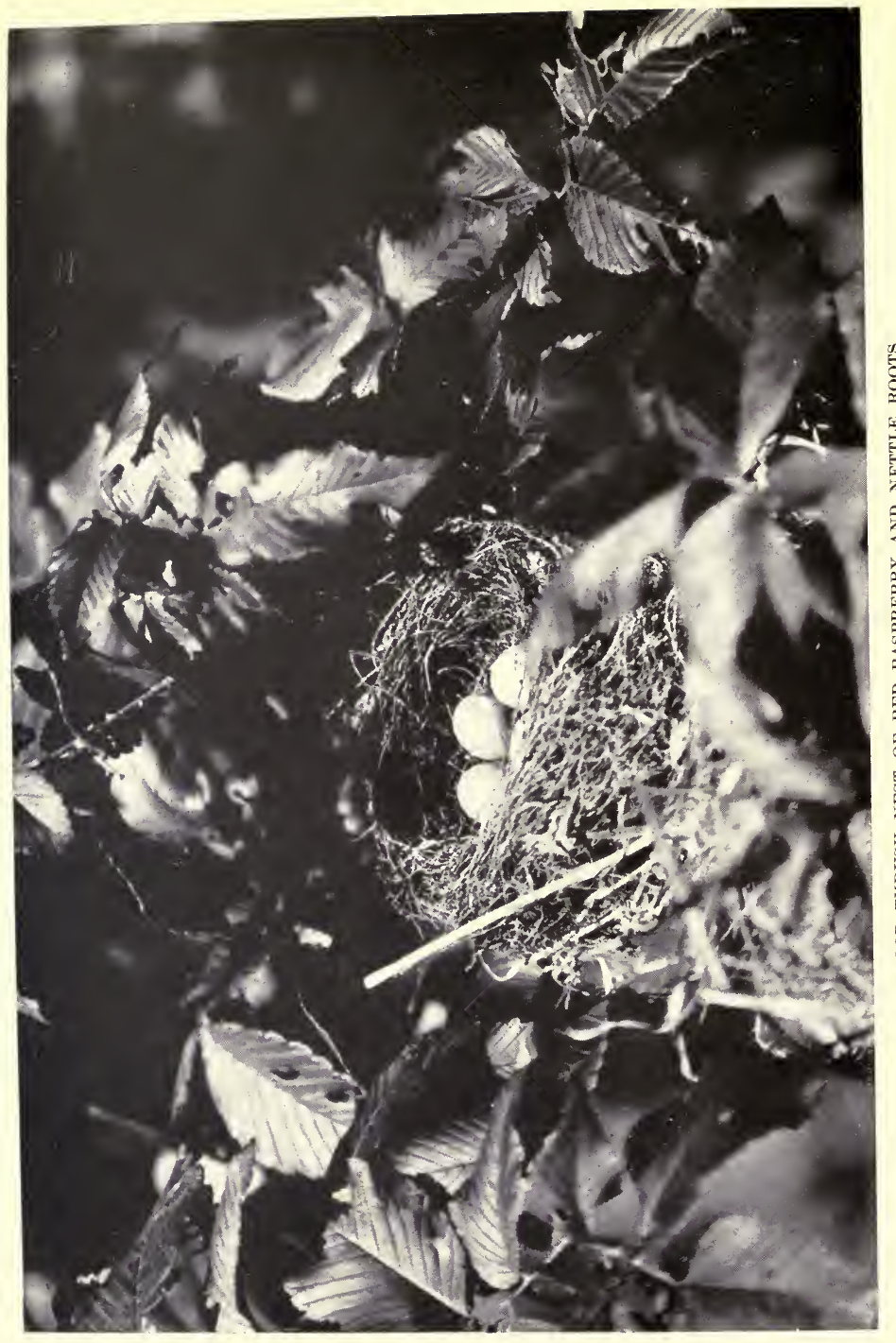

D 


\section{THE WOOD THRUSH}

and in my conservatory early in June there emerged from it a moth with a wing spread of six and three-quarter inches-the widest of the species I ever have seen. A. Woodcock was flushed and an hour spent in searching for her nest, when I remembered that my quest was for Bell Birds, so I returned to my original pursuit.

I had hunted until despairing when there was a brown flash above my head; a male Bell Bird flew over with a sharp warning chirp; then I realized I was close his home, so standing still I used my eyes to such good advantage that presently I was looking straight into the big, liquid, startled ones of Mother Bell Bird, as she peered down from an elm thicket close above me.

Oh, but she was beautiful! even in her plain colours, which after all were not so plain, for her back was a rich reddish brown and her breast snowy white, with long irregular markings of black. My plan had been to locate her that morning and go my way for a day's work elsewhere; but a nest on a dry plate is worth ten in a bush, for birds have hosts of enemies, so you never know with any certainty when you leave a nest one day that it will be safe the following. It could be seen at a glance that there was something most unusual about this nest, for it was bright as the back of the bird that brooded on it; so I hurried to the carriage for my step-ladder to use as a tripod, and a camera. I decided that I would bring a big one.

I felt that this nest was unique, and so it proved. It was the most surprisingly individual piece of bird architecture imaginable. Disdaining corn-husk, straw, and other material almost invariably chosen by their species, this pair of birds, with untold patience and labour, had digged from the ground the roots of red raspberries and nettles and woven them while wet into a deep cup. There was not a particle of lining and very little other foundation: nothing at all in the body of the nest except 


\section{FRIENDS IN FEATHERS}

these two kinds of roots. They had dried firmly as spun glass, then turned to a bright terra cotta colour. The long soaking the flood had given the valley made it possible for the birds to dig these roots; but how they ever broke them off the size they were is still an unsolved problem. The eggs were a Robin's delicate blue. In their bright cradle, with the tender green of the elm thicket all around, they made a picture that had to be seen to be appreciated fully.

After making a record of the nest that was to my satisfaction, I began courting the confidence of the mother bird-truly a delightful task! Every morning and almost every evening I visited the nest, each time going closer, making longer waits, moving with extreme caution, lest she become frightened, and always going through the operation of setting up the ladder and a small camera in front of the nest, to accustom her to the process; in the hope that I soon could approach near enough to make a study of her as she brooded.

Sometimes I crept into the thicket in the early morning when the bushes were heary with dew, when the breath of night lingered in the valley and when the Bell Bird and the Grosbeak were singing chants to the rising sun. Sometimes I lingered near the nest until late evening when the woods grew very still, lacking the chirp and chatter of many little heads now tucked in sleep. Then night's sounds would begin to rise in a steady volume around me. A raccoon living in a hollow tree near me could be heard getting ready for his nightly raid; tree-toads would sing intermittently. Whippoorwills set me shivering, and once in June a big golden Eccles Imperialis brushed my cheek. I had to let it go for fear pursuit would startle my bird and undo all my hours of watching with her, yet I would have given much to have captured that beautiful moth. Once while waiting near Mother Bell, climbing the ladder occasionally and softly talking to her, 


\section{THE WOOD THRUSH}

I sat on a $\log$ to rest. Something touched my foot and I looked down to see a big, black water-snake passing from pool to pool. It would not strike, save in self-defense; but I wonder if I shall ever learn my woodcraft sufficiently to see near me a snake, no matter how harmless, without a feeling of horror.

From the hour the mother bird felt the quickening to life of four little shell-incased bodies against her breast, she became a fanatic, so my work was easy. She allowed me to make studies of her on her nest and even to stroke her wing as she brooded. I never tried to pick her up. I thought of it and wondered if it could be done, but I was afraid she might grip with her feet and carry an egg from the nest-a danger not to be risked when there was no greater result to be accomplished than merely to prove that she could be handled.

After the nestlings hatched, they soon grew so accustomed to me that they cared not a particle whether their mother or I dropped the worms and berries into their mouths. Many interesting studies were secured of them but not one nearly equalling a pair of the young on the day they left the nest. These babies were bright, alert and sweet, beautifully coloured and very easy to coax into poses. Surely the male made as exquisite a singer as his father, and the female another brave tender-eyed mother bird.

The taking of these pictures was comparatively easy. Fighting my way through the thicket, carrying heary cameras, dragging a twenty-foot step-ladder for a tripod, avoiding poisonous vines, snakes, miring in muck, being stung by insects and scratched by briers was not so easy, but all that is in any real field-worker's daily life.

Here is a study of this rare and beautiful bird-home and of the pair of handsome youngsters hatched from it; but what would I not give if everyone could hear the Bell Bird's exquisite notes, 


\section{FRIENDS IN FEATHERS}

rolling down the valley, as he courted, comforted, and guarded his mate? All of my life I shall hear him as he would come hopping from branch to branch toward his choir-loft, tenderly questioning: "Uoli? Uoli?" Then in a burst of impassioned rapture, clear as the finest golden-toned flute: “A-e-o-l-e! A-e-o-l-e! leolee, lee, lee!"

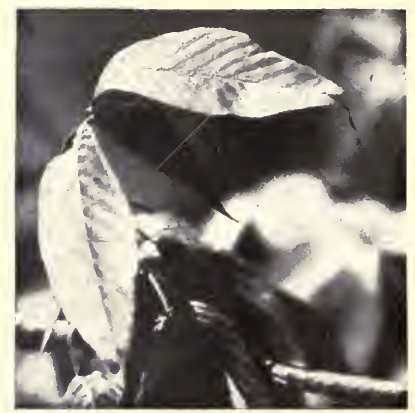

YOUNG BELL BIRD HIDING

UNDER LEAF 



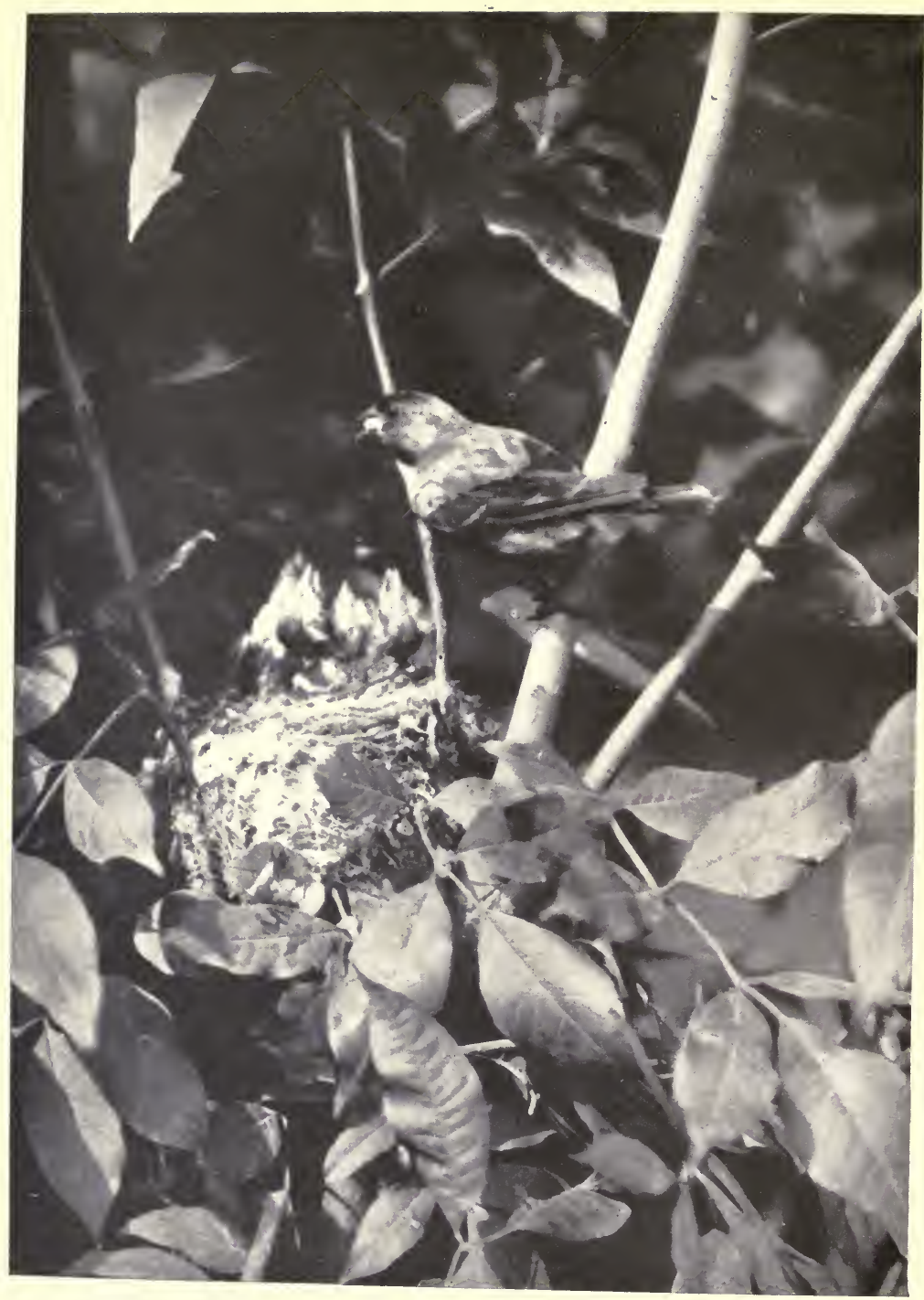

MALE GOLDFINCH FEEDING YOUNG 


\section{CHAPTER VII}

\section{Goldfinch: Astragalinus Tristis Pállidus}

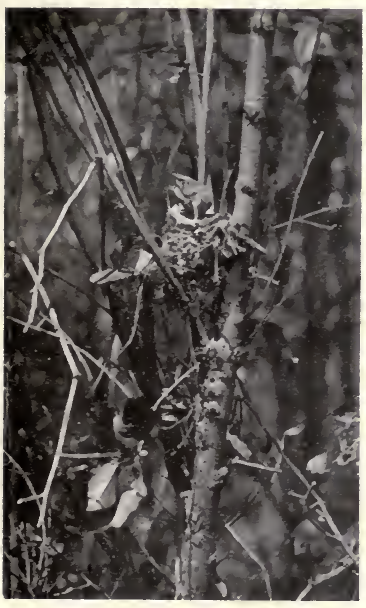

FEMALE GOLDFINCH ENTERING NEST

\section{IN BUSHES}

My first friendship with the Goldfinches began in my mother's garden. That possessive evokes a smile as I write it. Certainly father and the boys made that garden, yet it was always spoken of as mother's. It was as much a personal possession as her dress or her dishes. I smile again as I think of the garden. There was not a weed in it. The walks were smooth and broad, the beds held in shape by neatly staked boards. There were radishes, onions and lettuce, beets, cabbage and tomatoes, a herb bed, a strawberry bed, long rows of blackberry and raspberry bushes, currant and gooseberry, a grape arbour, and leek and garlic tucked away under some vines; yet the impression one had from the highway, the dooryard, or gate, was of a flower bed, for flowering shrubs filled the corners; hardy perennials bordered the front and side fences, over which clambered creeper, honeysuckle, and cypress vines; and annuals bordered and intermingled with the vegetables of each 


\section{FRIENDS IN FEATHERS}

bed. You could not see lettuce for larkspur, gaudy poppies flamed above the onions, radishes were extracted without disturbing the coreopsis. Buttercups, columbine, cinnamon pinks and every dear old-fashioned flower homed in that garden; possibly this explains why it was "mother's garden;" yet from it came strawberries for a family of fourteen, exclusive of help and guests; plenty of berries for jam and preserves, the same of every other berry and fruit in it; all the vegetables we could use, and many went to the neighbours, the minister and the pig pen; a huge kraut barrel was filled each fall from cabbage that had grown beneath castor beans and sunflowers; but always to us and to the public it appeared a flower garden, while one of the component parts of it were the flocks, literally flocks of Goldfinches that came each mid-August and from then until snowfall feasted on radish, lettuce and flower seeds.

They gathered from the fence rows, woods pasture and forest to come, a golden warbling company, rising and falling in short waves and spurts of flight, singing on wing until the bright summer air was heary with light, fragrance and melody; I filled my soul with enough of it to last a lifetime and send around the world from just "mother's garden." I am one dividend from that garden on which my mother did not reckon; she aspired to present a picture to the passerby and to her family, also to fill her conserve closet shelves; she never dreamed that she was writing future books, by proxy. So I sat among those flowers by the day, looking, listening, thinking very big thoughts for so small a person; to-day no part of the picture is more loved and bright in memory than the sweep of the singing throng rising over the high picket fence, then dropping on the swaying lettuce and radish seed stalks. Often they almost alighted on me; once one flew in our open front door and for a few palpitant seconds I held its little trembling body in my eager grasp. I was so loth 



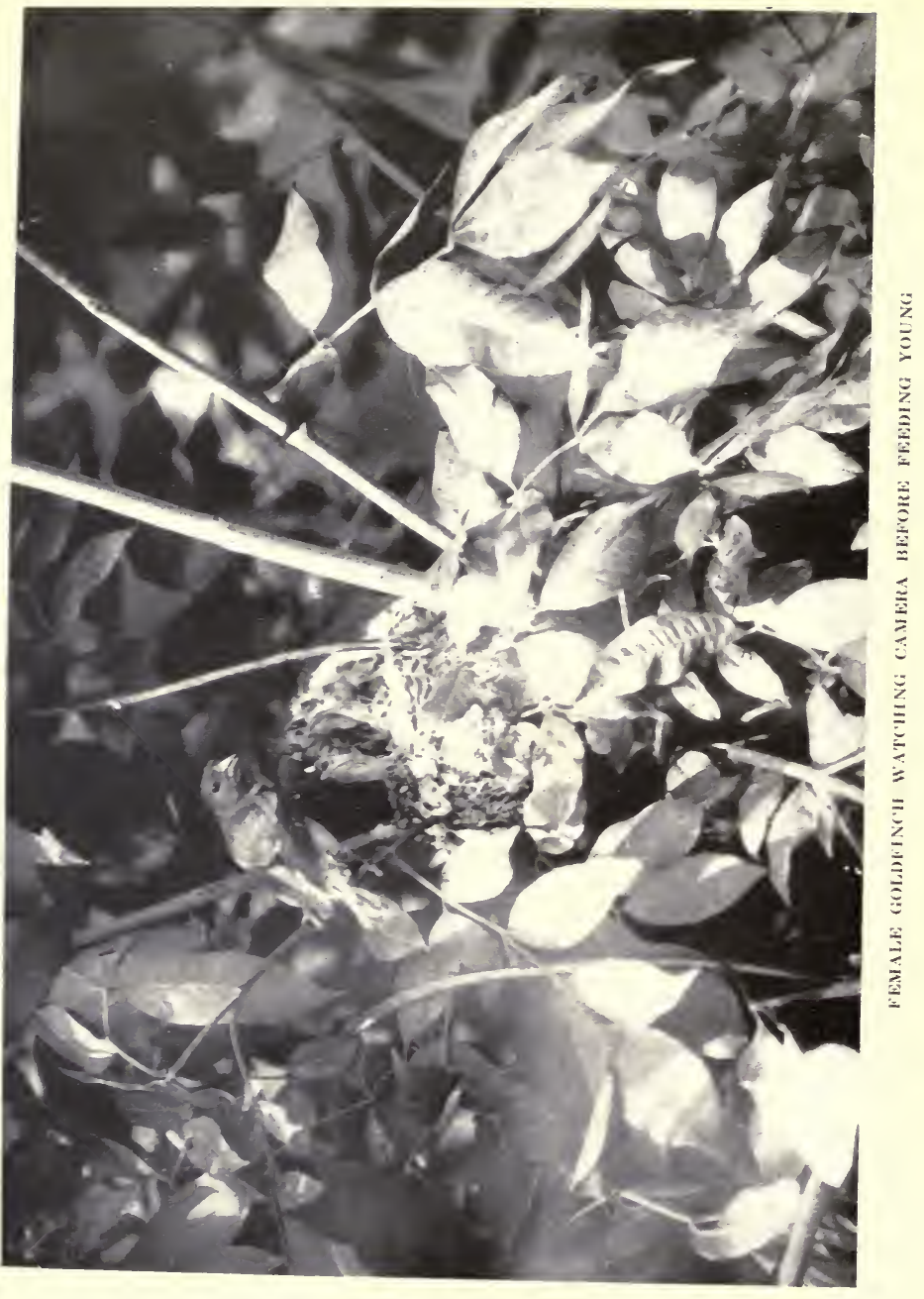




\section{GOLDFINCH}

to release it, I suggested an empty canary cage, recently devastated by a neighbour's prowling cat; but my mother said: "It is a tiny wild thing almost as delicate as the humming birds. Would you want to see it starving for the food it likes, its feathers draggled, its head bleeding from cage fighting?" We called them wild Canaries; that one was back to freedom before my mother's sentence was finished; then she scolded me for letting it go so quickly, because my sister Ada had not had her turn at holding it a minute. Such is life.

With all of that experience with the birds, I never had located and never had seen a nest until in my second summer of field work, when an oil pumper on our farm found one for me on the Martin lease adjoining. It was midsummer, as these birds come late and build but once. It was placed in the crotch at the branching of a small tree, being a very deep, large structure for the size of the bird. The material was dainty fine grass and weed stalks, bits of twig and moss, spider web and milkweed down liberally used in the side walls and rim, the lining a white silken bed. There were four eggs. Not knowing how recently the bird had begun brooding and not having a tripod tall enough to reproduce the eggs, which were a dull pale blue, having tiny dots on the larger end, in their nest of thistle and milkweed down, appearing like fine jewels, I set up and focussed the camera perhaps twenty feet away, covered it and went into seclusion. I heard the mother bird coming back. Baby Orioles are the most talkative children of birdland, with the possible exception of Swifts, but among the adults the chatter, chirp and song of the Goldfinch are as nearly continuous as any notes I know. They have such amiable dispositions, that were their songs less melodious, they would become a nuisance. Luckily, having the deep cavernous upper mandible of all Finches, they have, because of it, the mellow voice, full of music. 


\section{FRIENDS IN FEATHERS}

Their song and call notes strongly suggest the Canary; not that they either warble or trill, merely the sounds are alike, the Goldfinch notes being full, elear, melodious, and touched with the zest and joke of life to a degree not even equalled by the Bobolink. Bob gives a dizzying outpouring of notes rolling in a jumble, that sets the listener straining his ears, his mouth agape in the attempt to follow and interpret, but little gold bird never fails to make you smile, even to laugh aloud at his joy in life. Riding air waves he comes sailing toward you erying in full rising and falling notes of pure melody: "Pt'seet! Pt'seet!" Then his full strain: "Put seed in it! Put seed in it!" Always ending with the question: "Do you see me?"

I saw her. So when she alighted on the edge of her nest, a little olive greenish bird, of leafy shading like the foliage around her, I was ready, and as she leaned to closely inspect her eggs, I secured this likeness. Her gold-and-black mate must have been far afield. for I did not see him. The light was in the west. When I returned the following afternoon to try for a better picture of her and one of the eggs, I was disappointed to find that browsing cattle rushing among the bushes to scrape flies from their sides, had so bent and twisted this bush that the nest lay torn and trampled on the ground.

A few days later Bob told me about a nest he had found in the crotch of some ash bushes in a ditch, at the foot of the levee, at the east end of the Wabash River bridge, on the north side, on the Shimp farm. I could work on the nest for about one hour in the morning, as the light fell full on it only at that time, while the young were already hatched, pinfeathering, and able to stand and call for food. I set up a camera far enough away that they would see it and yet not be disturbed by it, left it there for a long time, then moved it eloser, and finally before leaving, trimmed and tied back the bushes all I dared, not to expose the nest. The following 


\section{GOLDFINCH}

morning I had my camera set at the right time, close enough to secure these pictures, as they are; covered it; tied back the bushes a little farther; and hiding, began waiting.

The young were clamorous for food. I thought there were six in the nest from the bobbing heads, but count on the plates proved only four. Both old birds constantly flew with food, which they had swallowed and then regurgitated in large white pellets, mostly hulled seeds no doubt. They did not empty the cloaca, the nest being completely encrusted on all sides without, but the young were clean, the elders dainty as possible. In the succeeding days I made numbers of studies, gradually moving the camera close and mostly preferring the male as he showed better on the plate. Each time I left I closed the bushes carefully; removing every trace of my work. I was training the young, and had them almost ready to take their pictures, when the morning hour found the nest empty; not a trace of any violence, but empty. I was sure they were not ready to go, but they were gone. With all the wooderaft I had at command, I could form no conclusions as to when or how they had disappeared. I could not hear them in the shrubbery, and not a note from the elders, so to-day I have no idea what happened to them, nor have I ever found another nest; yet each summer hundreds come to our garden and sunflower hedge, grown especially for their benefit.

Remembering my experience in mother's garden, I would advise anyone desiring to attract Goldfinches to their grounds to allow plenty of lettuce to go to seed in the garden. These birds also feast on radish seed, while they are perfect gourmands over the tiny grains of mustard seed.

During work on the Hardison Orioles of this book, I noticed in the old, country garden adjoining the orchard, such flocks of feeding Goldfinches that several times I was tempted to try to 


\section{FRIENDS IN FEATHERS}

set up the camera there and picture them as they fed. 'They seemed especially to congregate over a large bed of vegetable oyster plants, then in seed. They also flocked over the tall plants of the lady-finger, while they made a perfect picture on the brilliant heads of coxcomb; the tiny black seeds of which made an eagerly sought tidbit. Iny or all of these plants are liked by the Goldfinches, and with sunflowers and many others, will serve to bring to any private garden in their range a golden company, riding the air in waves of gay, musical flight.

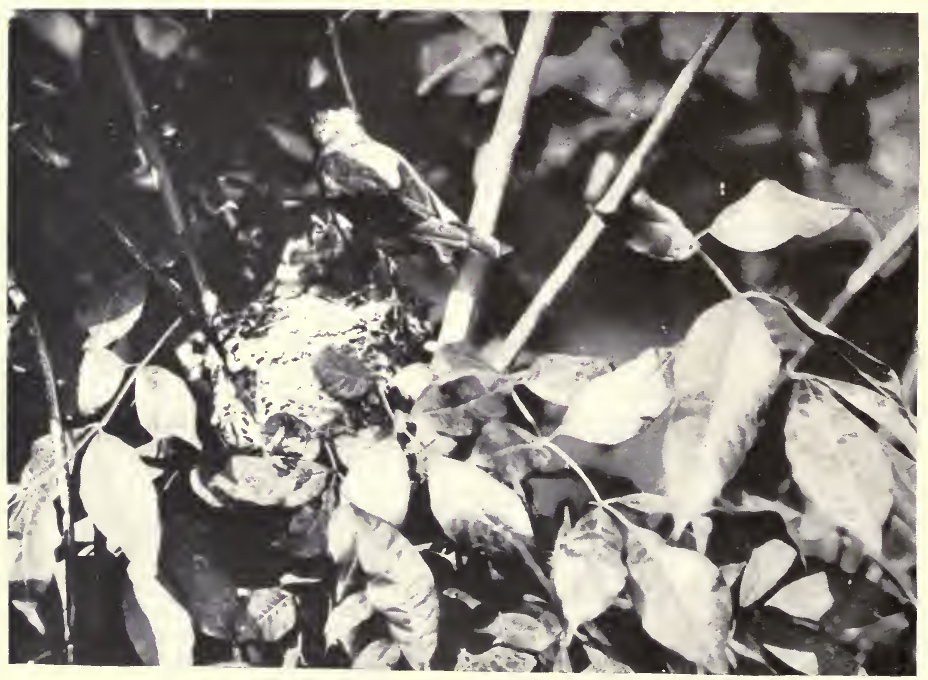

MALE GOLDFINCH AT EXCREMENT-COVERED NEST 



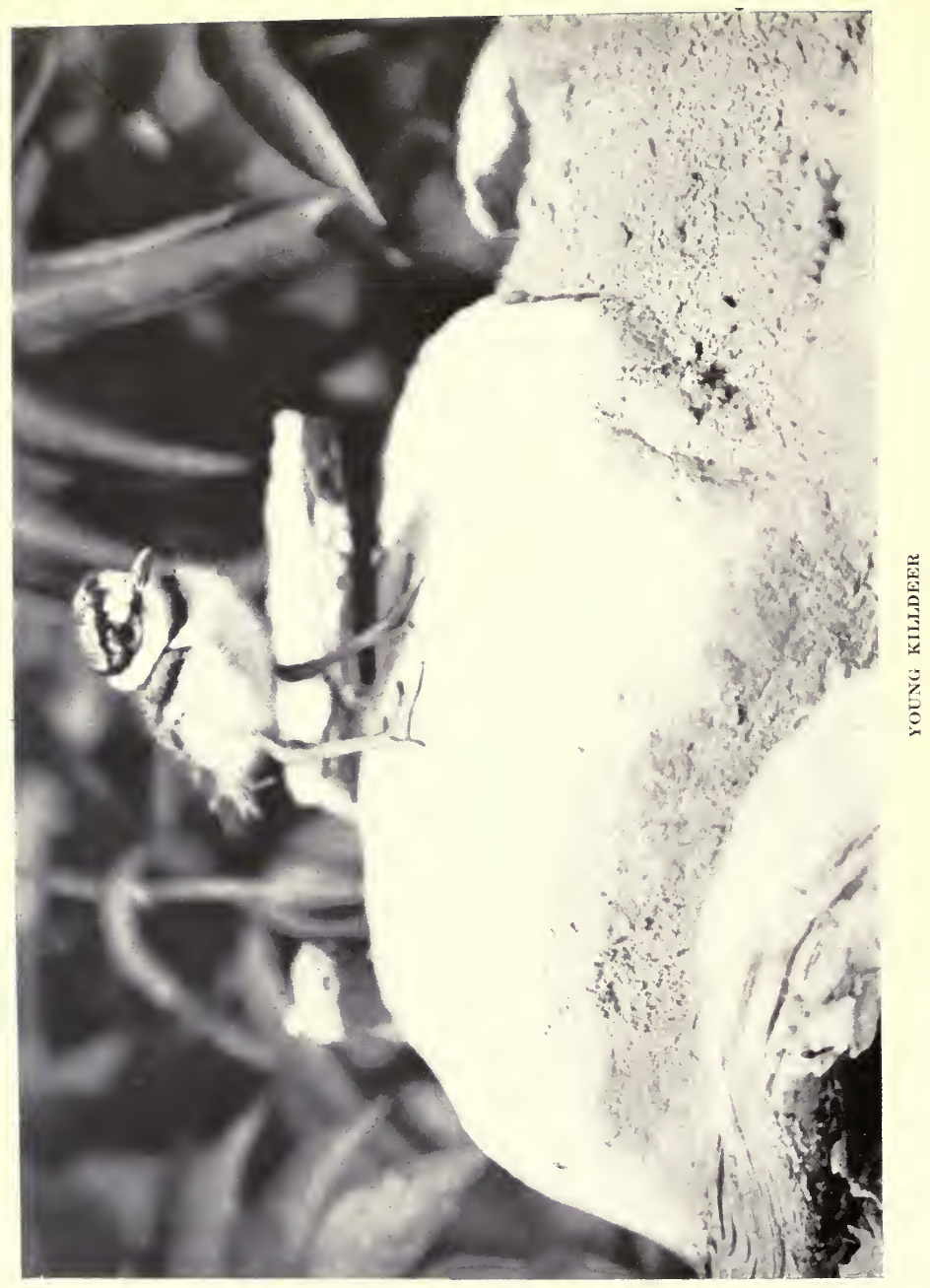




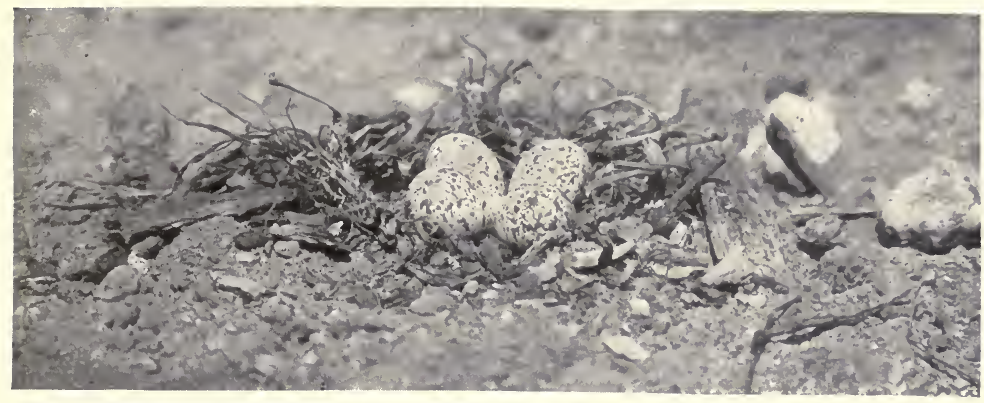

THE KILLDEER NEST

\section{CHAPTER VIII}

The Killdeer: Oxyéchus Vocíferus

ON THE GROUND

"JoHn has a nest for you," said a sweet-faced country woman, as she poured my second glass of buttermilk.

So many wonderful things come to me in that simple way, but my heart always gives the same old thump of delightful anticipation.

"Did he say what kind?" I questioned eagerly.

"He thinks it's one of these 'killdeer'-crying birds. It flew up right under the horses' noses and he had to pull back hard on them to save the nest. It's in the east corn-field, where he is working. He plowed around it and drove a stake to mark the place for you. There's four eggs and she's gone back to them."

I thought intently for' a moment. "One of these 'killdeer'- 


\section{FRIENIDS IN FEATHERS}

crying birds." I could not remember having seen a study of the nest of a Killdeer published, not even in a recent work devoted exclusively to bird architecture, or a reproduction of the young. I promptly hugged Mrs. Stukey, because I love these big-souled country people who save me nests, lay down their fences, offer food and a cooling drink, and try in every way to help me in work they do not always understand, merely because they enjoy being kind and helpful. Then I hurried to the east corn-field.

The gate from the road into the field was nailed shut, so I hitched my horse, whose original name was Ben, but regardless of sex, since has been changed to Patience; for obvious reasons; climbed the gate and started for what seemed like a stake far across the field. Part of my course lay between the weatherbeaten dry weeds and the stubble of last year's crop; the remainder over freshly plowed ground.

The open sumny field was almost a sheet of green in perspective, with the tender upspringing wild lettuce, silvery catnip, golden green dandelion and pale whitish burdock. The light green felt of the mullein and the rank dark green of the thistle spread everywhere in big plants, that had slept securely beneath the snows and renewed their vigorous growth before the last drifts of March had passed. It occurred to me to wonder if we had learned everything about thistles and mullein it was intended we should. These plants must have been made so rank and so hardy for some especial reason which I scarcely think we have found.

On nearing the plowed ground, a clamour broke on my ears and I stopped, enthralled by one of the most beautiful sights conceivable. Down the field came John, the lines hanging over a plow-handle, guiding his powerful gray Percherons by his voice, a black line of swamp loam rolling up as he passed, while myriads 


\section{THE KILLDEER}

of big birds were swarming over him or fighting for place on the freshly turned earth at his heels.

“T'check! T'check! T'chee!” cried a whole flock of Blackbirds, the sun flashing. on their iridescent satin wings and sleek heads, as they circled around or stepped gracefully down the furrow, searching for grubs. Sombre-coated Crows cawed in full-fed satisfaction, while plump-breasted Robins cried, "Kip, kip! Cut, cut, cut!"' in exultation over each juicy morsel. There was the azure flash of the Bluebird's wing as he occasionally stopped searching for nest locations along the old snake fence or in the high stumps to dart down for some small insect. There was the plaintive cry of the Killdeers, and the silver gleam of their snowy underwings and breasts as they hung over a pool, fed by wells drilled to produce oil and contrarily producing water; while Meadow Larks left their nests in the adjoining wheat-field, making excursions from high stumps and fence riders to secure their share of the feast, then returning again to proclaim the season with notes of piercing melody.

Twenty fields had been passed in the process of spring plowing that day; a few scared birds hanging over the fences or scattering before the crack of a shot-gun were all that could be seen. There was only one John above whom they swarmed in absolute confidence; there was only one John who paused a second now and then to kick'open big pieces of muck, or stooped to break them with his hands and fling the grubs to the birds. And was he not wise? Was not their trust in him, the company they were to him, the music they made for him, a soul-feast for any man? Was not every grub and worm eaten then one less to prey on his young crop later?

Long before I reached the stake set to guide me, a clear, musical "Te-dit! Te-dit!" rang from a sentinel above the swamp, then straight toward me on slender stilt-legs a female 


\section{FRIENDS IN FEATHERS}

Killdeer came running. She uttered a shrill cry and turned to the south, directly away from the stake, limping, hopping, and dragging a wing to attract my attention. That trick had been familiar to me ever since I could remember, so I went to the stake. The nest, or rather the eggs, were easily located by the small spot around which John had plowed.

There was very little nest to describe. On bare earth, surrounded by a few bits of bark, corn-stalk and chips, all picked up in the immediate vicinity, lay four tan-colomred eggs thickly sprinkled with dark brown and black, their slarp points nosing together so that a stiff wind could not roll them away-a wise provision of nature in case these improvident mothers neglect to surround them by any barriers at all, as so often occurs. When a few days of sunshine had dried the black earth around the nest to the exact colour of the eggs it would be impossible to distinguish it from the surroundings. I hunted a stone to drive deeper the stake which John had set for my guidance. Then arranging my camera, practically on the ground, a study of the eggs was made at once. I wanted it so much I was afraid of delay. There are times when in summing up the dangers which menace the birds from snakes, Hawks, Crows, Jays, squirrels, and other small animals, hunters, untaught children, and the trampling and tearing of browsing stock, it is really a marvel that a season produces the number of young that it does.

The next thing was to make friends with Mother Killdeer. In the light of early experiences, with one brooding Killdeer in particular, I had dreamed dreams and seen visions on my way to that nest. I dreamed of becoming so well acquainted with that mother bird that she would take a cricket from my fingers and allow me to stroke her wing as she brooded, for I once had done that with a bird of her kind. I saw a vision of pictures of the brooding bird, and possibly one as she left her nest with her young 


\section{THE KILLDEER}

around her, for I once was so familiar with a Killdeer she would have allowed me even greater familiarity than would be required for that.

There are birds which make me feel that the title of this book should be "Failures in Feathers." This Killdeer was one of my worst. She was a last-year's bird, this her first brooding. She was nervous and foolish. She would suffer the horses to come very close, but the first glimpse of John would send her a gray streak across the field. I tried to accustom her to a tripod; that she bore; but when a small camera covered with twigs was placed on it, she left her eggs and would not return.

She was accustomed to the open field. She deserted her nest at every device I could think of, circling above, crying so plaintively that my heart failed me until I removed the camera. She would not submit to a camera covered with a green cloth, grasses, or a false stump. My experience with her did much to confirm me in my belief that it is almost impossible to work with a young bird in lier first brooding: After a season or two and several nestings a female matures and grows in confidence. She learns to distinguish friends from enemies and unfamiliar objects from dangers, so that work about her can be carried on with some degree of assurance, especially after her eggs have quickened.

While lying awake nights trying to concoct some scheme whereby to outwit Mother Killdeer, I was compelled to miss one day's visit to her, and on going the following, found only a bare spot of earth surrounded by a few clods and chips. While I closely investigated to see if any signs of tragedy could be found, my ear caught the sweetest, faintest silver thread of a cry conceivable from the throat of a bird baby. I glanced toward the pool. Across its bare bank moved the brown and white body of the mother, her slender legs invisible in the rapidity of motion; 


\section{FRIENDS IN FEATHERS}

behind her, almost keeping pace, a tiny ball of down also invisibly propelled.

Pursuit began. The old bird at once took wing. Watching the baby I darted here and there, and ran and ran.

"Want help?" inquired my daughter from the carriage on the road.

“'Deed I do!' I panted, running faster.

Molly-Cotton joined the chase. After repeated failures, we caught him. We were breathless, dishevelled, while he was not even "winded." Ile certainly was the most exquisite bird baby I ever handled. His entire covering was of the softest. silkiest down. On his head was a little tan cap, sprinkled with pepper-and-salt, having a black band, chin strap, and a white vizor. Around his throat was a broad snowy collar with a narrow black tie. His coat and the upper half of his sleeves were the same as his cap. The lower sleeve was white, separated from the upper by a black band. His rest began snowy white at the collar, then shaded through delicate gradations to an exquisite salmon pink. He had a small neat long bill, long bare legs and the big prominent eyes of the nocturnal feeder, for Killdeer feed and fly at night when they choose.

We expended what breath we had left in going into raptures over his suit, and the sweetness of his balby voice. Then MollyCotton held the bird while a camera was set up. She placed him on the bank while I focussed sharply on his head and her hands. Then I put in a quick plate, set the shutter at the one hundredth of a second and told her to let him go. He went. He laad covered a rod before I sufficiently recovered from my surprise to see that no exposure had been made. Then I realized that a plate had been saved, for there would have been nothing on it.

No record was kept of the trials we gave him or the different 108 


\section{THE KILLDEER}

methods we used. We worked two and one half hours over him. We were bathed in perspiration, had crimson faces, were breathless, our hats lost, our clothing torn on the bushes, our hands and faces scratched, our feet bruised and twisted with the stones, while close before us that little dandy, in his elaborate suit, moved like a tiny airship, fresh as at the start. He travelled as easily as a puff of thistledown rolling before the wind.

"We can keep this up forever___" I began.

"No, we can't," interrupted Molly-Cotton; "the sun is that hot, I am so dizzy I can't see. I'll step on him next."

She was right. We were so tired we were in danger of stumbling and hurting the bird, while he was a runner that could keep on all day.

He had crossed one big stone repeatedly. I usually twisted my foot in going over it. I left Molly-Cotton to watch the baby and focussed sharply on that stone, heaping sand against it with my hands, so that he could run up it easily. There were bushes behind it, so stones and rotten wood were piled among them until a thick wall was formed. Then a focussing cloth was staked before the camera, so that he would not run toward that, the shutter moved up to the one five-hundredth of a second, then MollyCotton was asked to turn him slowly and carefully that way once again. The first time he crossed was a failure.

I manœuvred him back; Molly-Cotton turned him toward the stone again. Twice he darted past. That was stopped by blocking the path he took with pieces of wood. "The fourth time Molly-Cotton started him my way I moved closer to the stone than before. As the tiny legs flashed up it, I loomed so large on the other side that for one smallest fraction of a second he hesitated. Then he went free, for in that instant I had secured his likeness. 


\section{FRIENDS IN FEATHERS}

This spring a little friend found a nest from which all the brood had gone, save one. This bird was so recently from the shell the down was scarcely dry; so I obtained a reproduction of it before it was strong enough to stand.

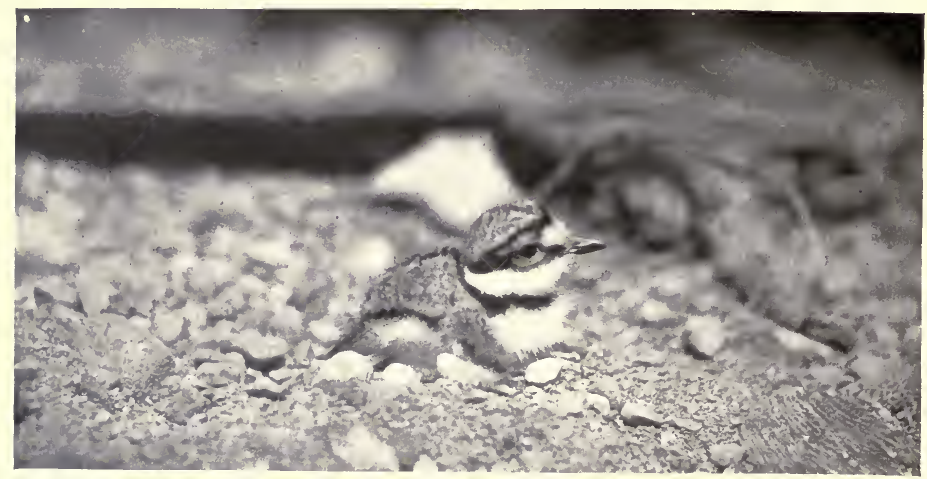

BABY KILLDEER JUST FROM SHELL

Notice how the three distinct colours on him fit into the surrounding landscape 



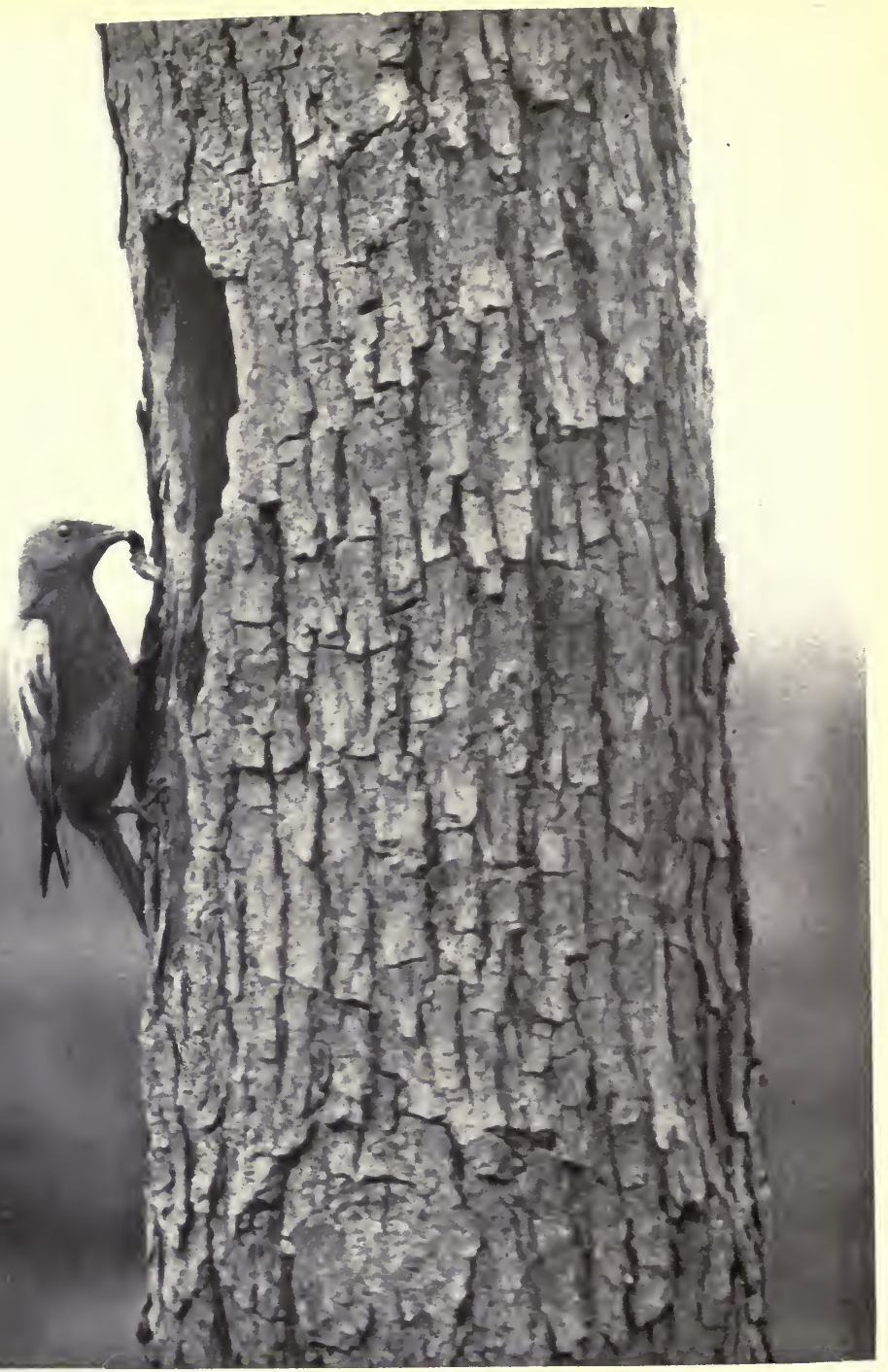

MALE BLEEBIRD CARRYING FOOD 


\section{CHAPTER IX}

\section{The Bluebird: Sialia Sialis}

IN ORCHARDS AND BIRD BOXES

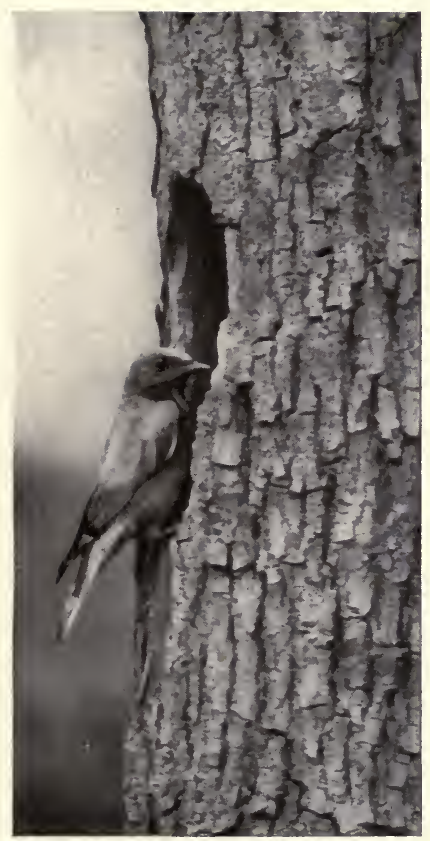

FEMALE AT NEST, HER FACE SERIOUS AS USUAL
No BIRDS, not even Robins and Wrens, are more component parts of a home in the country or village than Bluebirds. They are among the very earliest arrivals, often coming before frost and snow time is past. The ancient Chinese pronounced blue "the perfect colour." Never is blue among birds found in such perfection as on the back of a male Bluebird far advanced in life. Then, too, coming before foliage, and building by preference in hollow rails, trees, limbs and prepared bird boxes, he drops low and takes wing in plain sight, so that we have the benefit of his beautiful colour at close range, without the shadowing foliage. The female is not so bright blue as the male, but by comparison with the male she is much bluer than a hen Cardinal is red. 


\section{FRIENDS IN FEATHERS}

There is no bird more friendly with man or more welcome; a vision for the eyes, forever changing from almost silver lights to deep turquoise and deeper indigo, as light and shadow effect it; the earliest song bird, the song a minor strain made up of a few notes resembling the Robin's in grouping, but the tonal quality very different. The Robin holds up his head and sings in ecstasy, for the pure delight of living. licpuid, ringing notes; the Bluebird wavers and cuavers out almost the same notes, yet so different in tone and delivery that few would notice the similarity in the character of the song. Sometimes I wonder if Bluebirds have acepuired this plaintive song from the griefs that so often befall them in their home life; for it has been my experience that nesting Bluebirds come to grief ten times to the Robins' once.

This, no doubt, comes from the nesting locations Bluebirds choose, and the fact that they love to build in bird-houses placed for them, where often they can be reached by cats and scuirrels, while it is impossible so to construct a box that it will admit a Bluebird and exclude a sparrow. My childhood home was beloved of Bluebirds, where they were protected and given encouragement, yet disaster seemed to follow them. The cattle pushed their hollow rail from the fence, the red squirrel found the nest. the wind broke the hollow limb from the apple-tree, or the neighbour's cat eame down and climbed the hollow post in the woodyard. In my own home the particular bane of the Bluebird is the English Sparrow. I could fill a book with stories of their encounters, the Bluebirds always being beaten out with one exception, for we had no recourse against the Sparrows save the little shot gun, the crack of which always frightened away the Bluebirds. They would not defend themselves against the Sparrows, although they seemed large and strong enough.

One nest I destroyed myself. Late in the fall I had the 



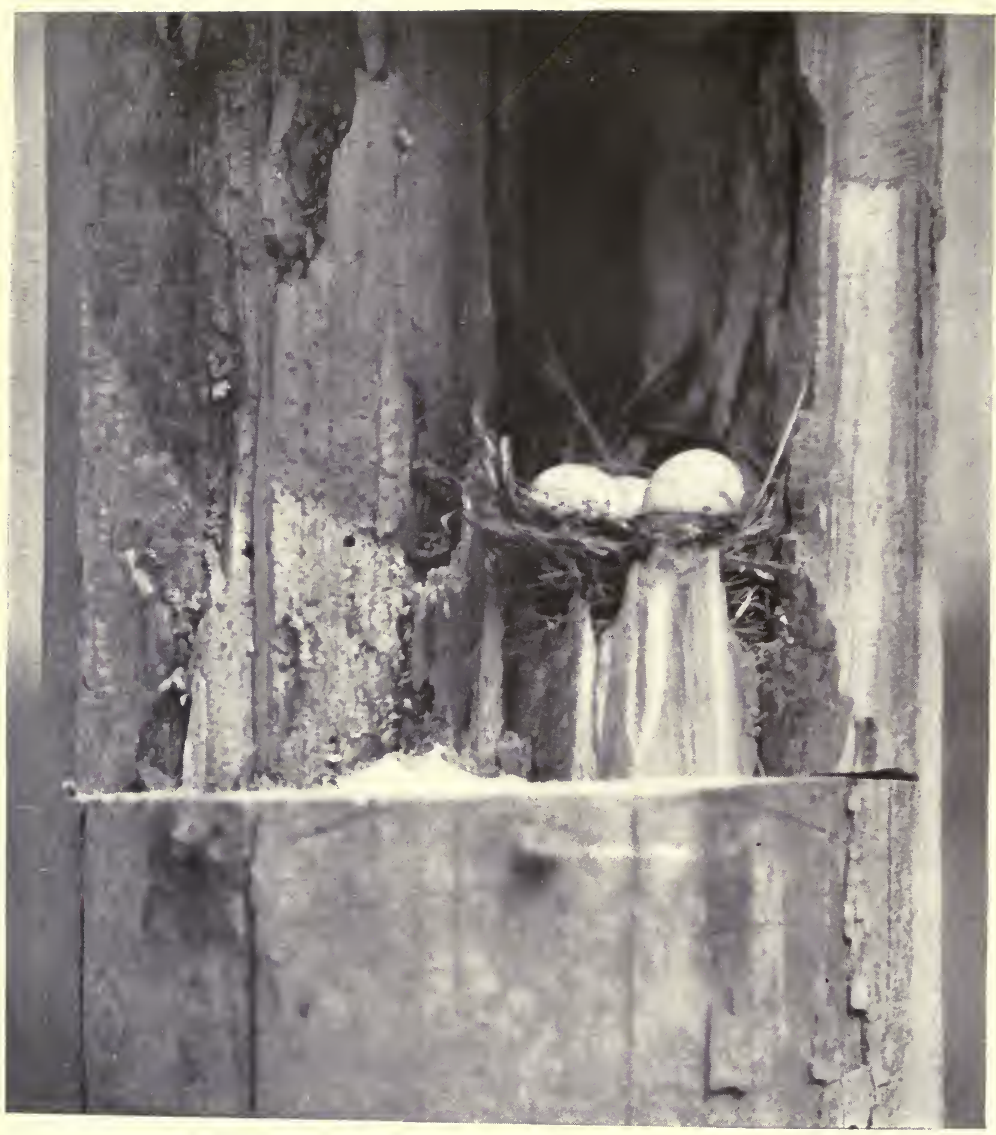

BLUEBIRD NEST AND EGGS 


\section{THE BLUEBIRD}

gardener take a box from the grape-arbour and turn it entrance down for its protection during winter. Early in the spring I saw Bluebirds over the arbour; no one being at home I placed a ladder, took the hammer and some nails and went to put the box in its accustomed place. They had entered it, built, and three eggs had been laid all of which were broken when I, with the best intentions in the world, tried to fix the box for them. So it continued, always the Bluebirds coming, seldom bringing off a brood.

The past season the Deacon took the matter in hand. He built three boxes, from upright hollow limbs, placing them high on slender poles at the back of the orchard adjoining the meadow. Each box had a Bluebird nest, each brought off a brood. I think he could fill a dozen the coming spring, for the young have remained around the premises and no doubt will return. Their notes are carried down on every breeze, while they trail blue streaks beside the car each time we drive out the lane. There is no such thing as having too many as they are splendid insectand worm-exterminators, taking some seed also; there is no lovelier bird on wing, and no more loved note of spring music.

They prefer to nest in a natural hollow limb, rather slender; they both carry material, the female as always shaping and building around her own breast the grass, weed-stalks and hair lining both carry. The eggs seem large for the size of the bird, being of a delicate whitish-blue, none that I ever saw showing a trace of mottling. Owing to the concealed nests, the only way to picture them is to fashion a house with a removable roof or cut a section from the side of a hollow tree they have built in. and when the picture is made, use screws in closing the opening. Nailing might jar the eggs.

The young have grayish-blue backs and full breasts strongly mottled with white and gravish-russet. In feeding, the father is 


\section{FRIENDS IN FEATHERS}

more active than the mother. At one nest on which I worked in fine light and comfortable location, the male came four times to the female's once, yet he seemed more timid before the camera than she. They always brought the bugs and worms, the latter preferably, and fed them direct to the young, emptying a cloaca at each trip; lovable, delightful birds with which to fellowship. The coming season I shall put up a dozen boxes, even more, scattered all the way around the orchard, where Bluebirds' work with small caterpillars is as good an economic proposition as their colour and song is from an artistic standpoint; although I do not uphold the song as much of a musical performance, yet I love it, possibly because it means spring has come.

Examine these studies of grown birds and young closely, and see if you do not agree with me that these are serious birds; tender and gentle, I grant, but taking the business of life as heary responsibility. In long and uncounted hours of watching around their nests, these are almost the only birds I never have seen play. The male does not pretend he is going to pick his mate, and then not do it, or indulge in love taps. She does not pay the slightest attention to him or offer him a caress either in jest or reality.

Once I saw a male depart enough from the even tenor of his ways to exhibit temper. He came early and strongly approved of a box I had ready, where I could plainly see it from a window. Several days later the Deacon and I happened to be watching together when he conducted her to the flat, and discoursed volubly; they are extremely voluble birds, on its every merit. She was not even politely interested. He urged her to enter, going in and coming out repeatedly to show her it was all right, all the time talking a blue streak, flying one also; but no response. Then he went to the ground and gathered a big beakful of nest material. Is he reached the entrance with it, he 


\section{THE BLUEBIRD}

glanced where she had been sitting in time to see her indifferently flying away. He swore undeniably, jerking his head until the material he carried scattered a yard as he angrily threw it down. He sat looking after her for some time, chirping forcefully, then shrugged his shoulders, a bird shrug, and slowly followed. I think a Goldfinch has more pure fun out of life in one hour than a Bluebird has in a lifetime. But a Goldfinch comes late, nests once, and is almost never molested, being the dainty idol of birdland. The Bluebirds have arrived at the Cabin in February. They breast cold, ice and storm, spring gale and downpour, frequently lose their nests and young, and are often engaged in bringing up two and even three broods to the season, so that my contention that they are serious birds is well founded, even admitting their garrulousness, while the minor strain in their song may be the result of these very things.

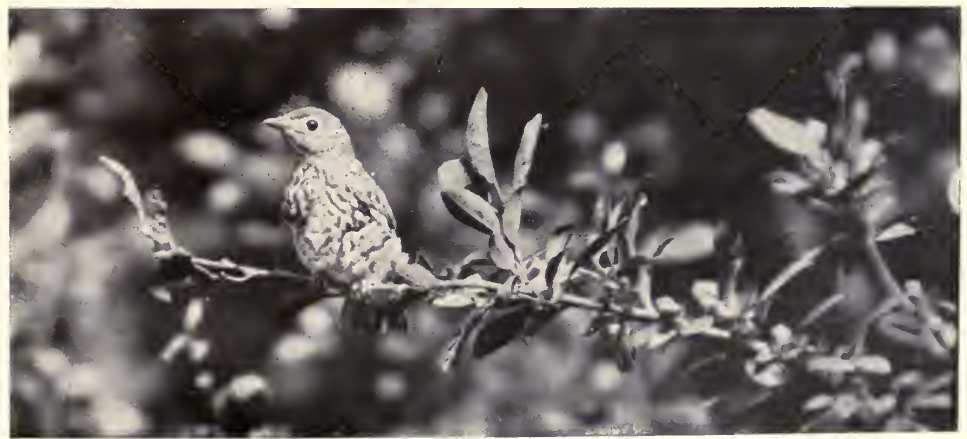

YOUNG BLUEBIRD 
"so the Bluebirds have contracted, have they, for a house? And a nest is under way for little Mr. Wren?"

"Hush, dear, hush! Be quiet, dear! quiet as a mouse. These are weighty secrets and we must whisper them." -Susan Coolridge. 



\section{CHAPTER X}

Black Vulture: Cathar'ista Uruba

IN THE LIMBERLOST

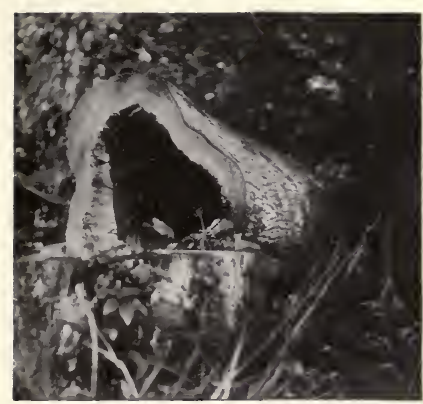

THE BIACK VULTURE'S FRONT DOOR

I AM indebted to Otty Bolds, who owns that portion of the Limberlost selected as their happy home by the Black Vultures, for word of their location. Mr. Bolds sent a messenger to tell me that in a big hollow elm tree, of last year's felling, was a nest containing a bird baby as big as a Gosling, but white as snow, and beside it a pale blue egg heavily speckled with brown and shaped like a Hen's, but large as a Turkey's.

This was bewildering. I knew where for three years Turkey Buzzards had nested in a hollow tree on the Wabash River, on Dan Hawbaker's farm, but their eggs were cream-coloured. The blue eggs "sent me to sea." We liad no native bird that laid the egg described. If the description were at all correct, it could only mean something unusual, and strays in ornithology are extremely interesting.

On hearing of a bird that is new to me I think of Pliny's classification of species; “those that have hooked tallons, as Hawkes; or long round claws, as Hennes; or else they be broad, flat and 


\section{FRIENDS IN FEATHERS}

whole-footed, as Geese," wondering in which class the bird can be placed. I was all eagerness to see these birds, but hesitated, not because of doubts that I would go and make studies of them eventually, but because it required thinking as to how it could be accomplished. The Limberlost, at that time, was my one spot of forbidden territory. A rash promise had been made never to go there, but this sounded too alluring. I immediately sought the Deacon.

"I want to take back my promise not to go to the Limberlost," I said.

"Can't release you," he answered.

We do not live long with people in this world until we discover their weak spots. The Deacon's is relics, specimens and curiosfirst cousin to natural history.

"What a pity!" I murmured meditatively. "This is the only opportunity I ever have had to reproduce a white baby as large as a Gosling, with a big speckled blue egg beside it, and of course I'll never have another."

"What's that!" cried the Deacon.

"How do you expect me to tell what it is, if I must not go and see?" I countered.

"When did you want to go?" he questioned.

I thought of the old adage about striking the hot uron and answered promptly: "This minute!"

"But I can't go now," said the Deacon.

"Then the blue egg will hatch, so I won't get a picture of it beside the white baby. I am reliably informed that it has large dark speckles on it - the egg, not the baby. Mr. Bolds sent a man to tell me."

"Imph!" he muttered starting toward the stable.

My soul was joyful as I went to pack my paraphernalia.

This was the beginning of a series of swamp-studies that is, in 



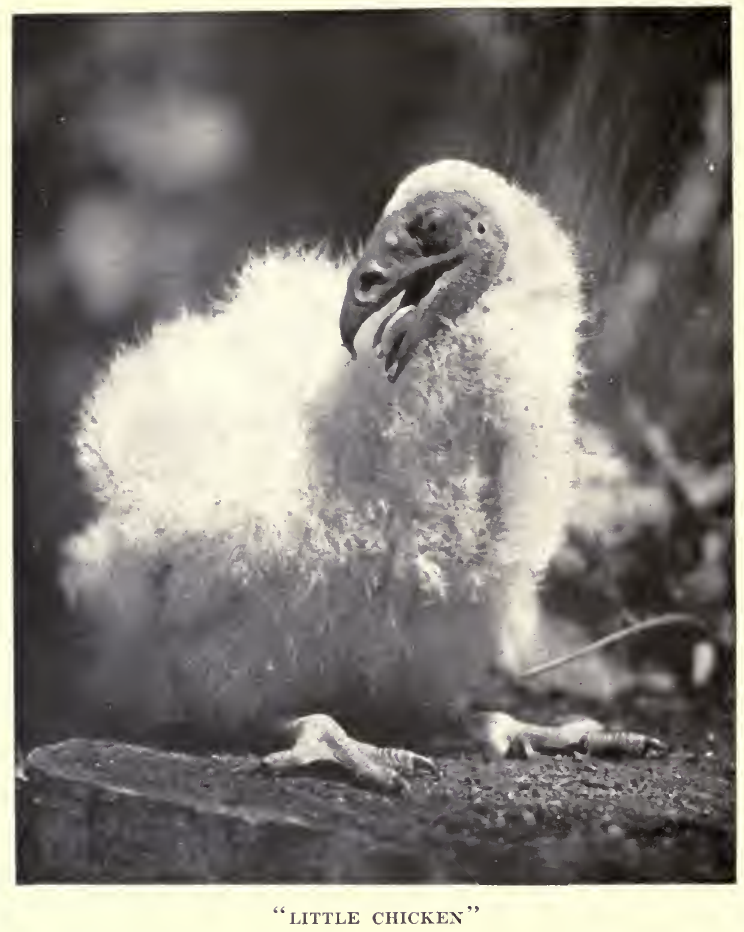

"From Little Chicken, before he stood erect to walk, I secured this study, which covers every possible natural history point, even the tongue" 


\section{BLACK VULTURE}

all probability, without an equal in natural history or photography. The Limberlost at that time was dangerous. It had not been shorn, branded and tamed. There were excellent reasons why I should not go there. Most of it was impenetrable. There had been one or two roads cut by expert lumbermen, who had located valuable trees; a very little timber had been taken out. No one knew when tree-hunters were there, while always it had been a rendezvous for outlaws and cutthroats in hiding. 'The swamp was named for a man who became lost in its fastnesses and wandered around, failing to find a way out until he died of starvation. In its physical aspect it was steaming, fetid, treacherous swamp and quagmire, filled with every danger common to the central states.

A few oil-wells had been drilled near the head of the swamp. It was over a road, cut to one of these, that we were to travel as far as a certain well. After that the way led north a quarter of a mile, then straight east, until we came to the prostrate trunk of a giant elm, with a hollow five feet in diameter. That sounds easy, but it was not. In the beginning $I$ had to pay a tenant a dollar for the privilege of driving over the road the oil and lumbermen used. A rod inside the swamp the carriage wheels on one side mired to the hub. Another rod, I took the camera intended for use in my lap, shielding it with my arms. Every few yards, I expected the light carriage we drove to be twisted to pieces. We left it at the oil-well, starting on foot with an ax, hatchet and two revolvers, to find the tree.

The Deacon wore high, heavy leather boots, while I wore waist-high rubber waders. We had to cut our way before us, as the felled tree had been hollow, not worth taking out, so no road had been made to it. For two hours we searehed for that log. The time was late June; there was not a breath of air stirring in the swamp; there were steaming, fetid pools everywhere, swarms 


\section{FRIENIOS IN FEATIIERS}

of flies, gnats, mosquitoes, and poisonous insects, masses of poisonous vines, while at every step not only the ground, but the bushes, had to be watched for rattlesnakes. The muck was so spongy we sank ankle-decp, branches scratched or tore at us while logs we thought were solid let us down knee-deep.

An observer readily could have seen that the Deacon had his cognomen by contraries. His face was crimsen, his wet clothing plastered to his shoulders. He smoked one cigar after another to drive the clouds of insects from his head and neck. The portion of my body covered by rubber was in a Turkish bath, while the remainder was bitten until I was lumpy as a beaded pincushion, but every breath was a prayer that the Deacon would not lose his patience or give up. And he did not! Of course we had to find it after a while, when we searched like that.

I was glad that it was the Deacon who first sighted the location. He would be more interested in it if he did. When we reached the tree, a big black hird was brooding. We held a council. I must have the bahy while it was a tiny baby and the blue egg if possible. A camera was set up and focussed on the mouth of the log. The Deacon plunged into the swamp and started back beside the trunk, tapping it gently to drive out the bird. She was to be snapped as she emerged.

The light was bad, but the experiment was worth a plate. We did not dare risk frightening the bird by doing any clearing while she was brooding. These matters must be handled delicately and with common sense. To cut down a tree with her watching us, in all probability meant to frighten her into creeping to the farthermost recesses of the log, where she might refuse to come out for hours. Then for the Deacon to enter to bring out the baby while she was there would mean to give her a fright from which she would never recover; one that might result in her deserting the nest. She must be coaxed out, before any clearing 



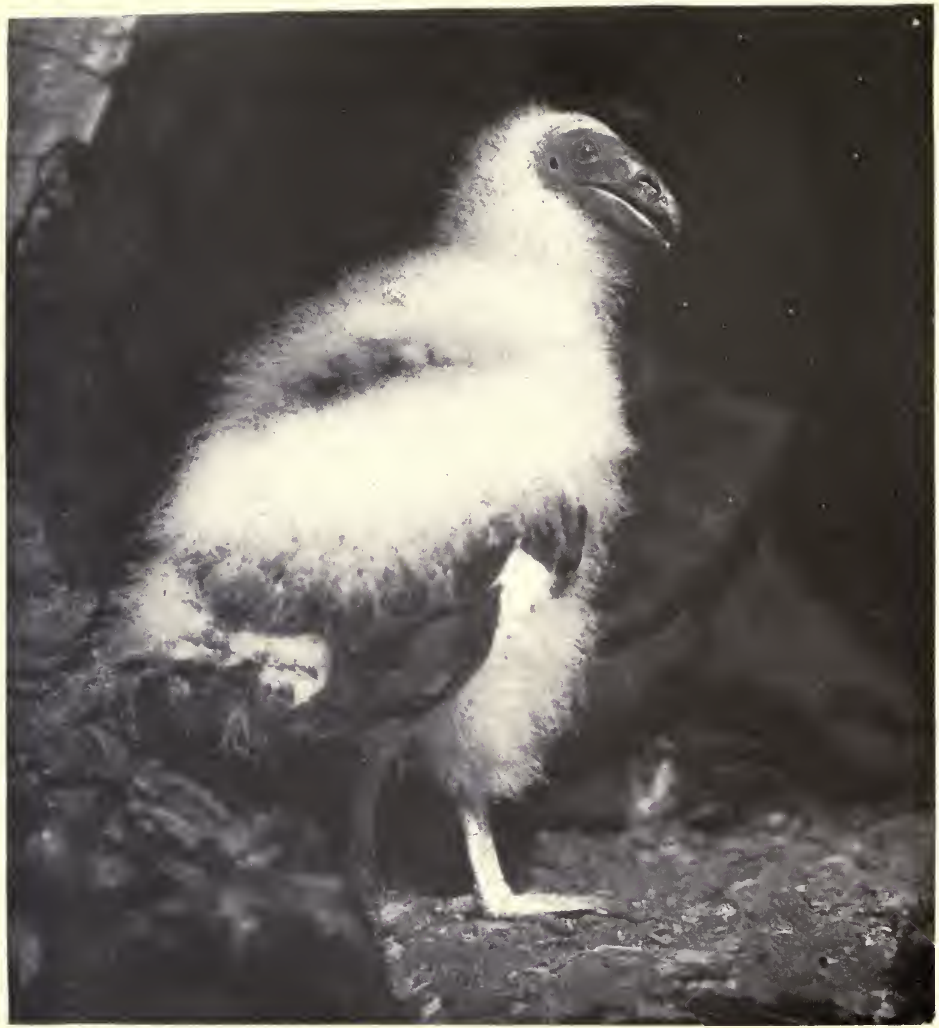

THREE-FOURTHS GROWN

"No actor could surpass him in poses" 


\section{BLACK VULTURE}

to throw light on the opening was done. I was watching the log, my shaking fingers grasping the bulb. I had depended on her walking to the opening, then flying from there. She came out on wing, with a rush. My shutter was set too slow for flight. There was only an indistinct wave across my plate.

Then the Deacon entered the log, creeping its length, to carry out the baby and the egg in his hat, which we previously had lined with leaves. The odour was so unbearable we could work close the log only by dipping our handkerchiefs in disinfectant, then binding them over our mouths and nostrils. The Deacon said there was not a trace of nest. The baby and the egg were in a small hollow in the decayed, yellow elm fiber.

The baby was cunning as possible, white and soft as a powderpuff. He had a little, quaint, leathery, black old face. The unhatched egg was beautiful, but too light weight to contain a young bird ready to pip the shell. We at once named the baby "Little Chicken," after Pharaoh's Chickens of old. The Deacon placed him in the mouth of the log, exactly as he found him, while I cut away vines to make a footing. Then we cut down several trees and bushes to secure a good light on the mouth of the log. A study was made of the location, two of Little Chicken and the egg, finally one of the baby alone.

Then the Deacon crept back into the log to replace the baby and the egg, although we knew it would not hatch. The following morning the mother broke it and ate the contents.

The birds were Black Vultures, the pioneers of their kind in this part of the country. The female was a brilliant young bird, with fresh face and feet. The male was much larger than his mate, duller of colouring, with a wrinkled old face, while his feet and legs were encrusted with a lime-coloured growth at which he bit and worked.

When we left the swamp we were so overheated that we 


\section{FRIENDS IN FEATHERS}

chilled until we were compelled to wrap ourselves in the side curtains and lap-robe of the carriage, lower the top so that we sat in the sun of a hot June day, and to drive at a slow walk. The Deacon turned to me with the first word he had uttered, save to ask what I wanted done next, and inquired: "Do you think that paid?"

Never in all my life had I been so uncomfortable, so unspeakably miserable. I was chilling until I shook under my leather covering, so pretended not to hear him. The following morning I produced my bunch of proofs.

"Do you think it paid?" I asked.

The Deacon examined the proofs several times, finally selecting the best one of Little Chicken and the egg.

"That more than pays," he said succinctly. "When are we going again?",

"I want to go every day to feed Little Chicken some liver or" sweetbreads and become acquainted with his parents. I want to make a study of him every three days; as many as I can of the old ones," I answered.

"All right!" said the Deacon.

"But you can't spare all that time," I cried in astonishment.

"I must," said the Deacon. "No one less careful of you than I am ever shall take you to the Limberlost."

So for weeks, until October, in fact, we watched over that baby and courted his parents. We found in our woods a dead calf which we carried into the swamp, placing it conveniently for the old ones and for me to take pictures of them. When Little Chicken was a few weeks old, without our knowledge lumbermen removed the log for a watering-trough, but sent me word where they had placed the baby. His parents were very indifferent about feeding him in his new location so I had to visit him daily. Once when I was called from town for several days 



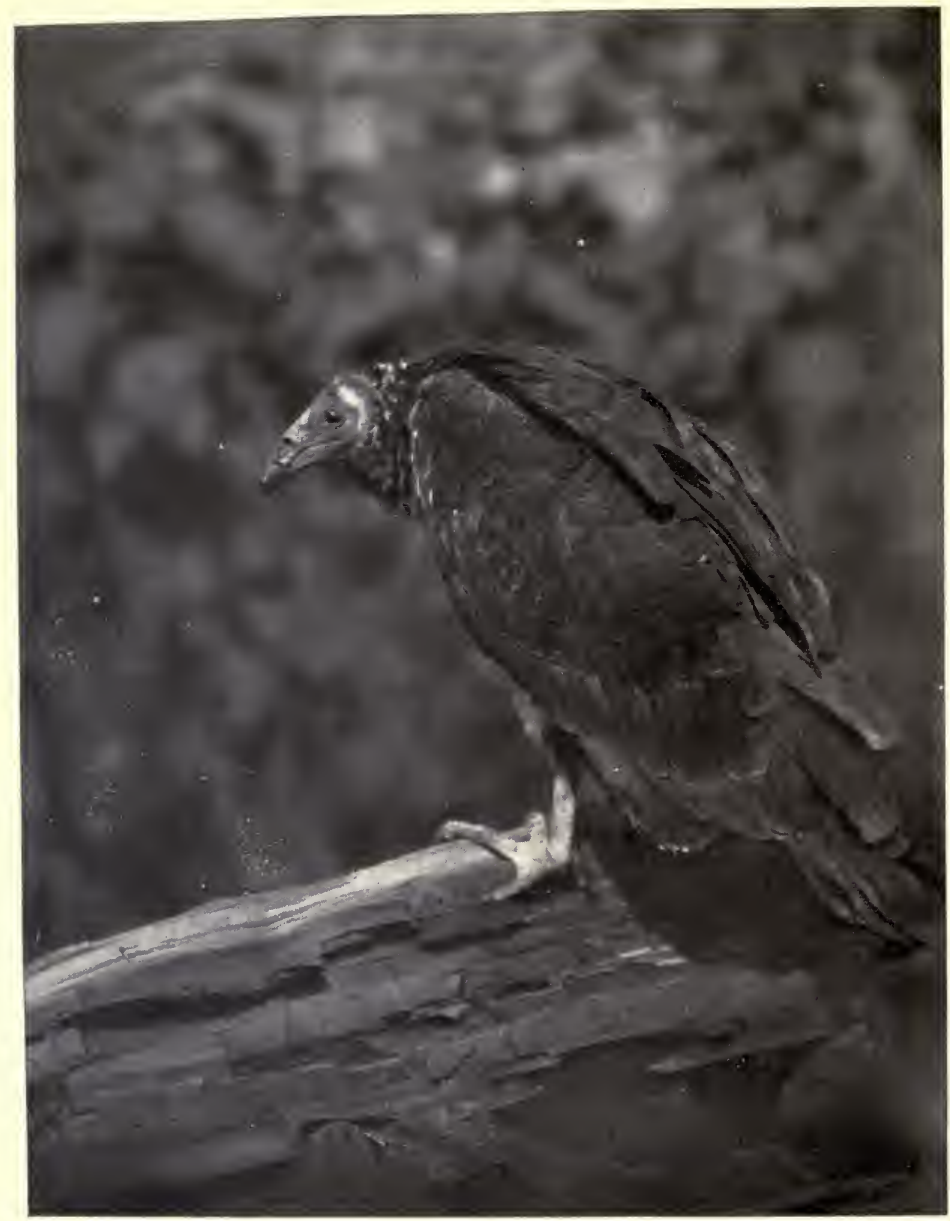

BLACK VULTURE

"When he was almost full-grown and only a trace of down showed around his ears, he would follow me across the swamp", 


\section{BLACK VULTURE}

he was brought to the Cabin, in the carriage. A woman was hired to feed him until my return, when he was taken back to the swamp. There is no way of adequately describing what we endured for that series of pictures.

The birds were friendly, the male especially, and responded beautifully to our advances. From Little Chicken just before he stood to walk, I secured the study here given, which covers every natural history point possible to one photograph, even the tongue. The baby was obliging about posing, while in two weeks he answered to his name and took food from my hand as readily as from his mother. When he was almost full-grown with only a trace of down showing around his ears, he would follow me across the swamp with his queer rocking walk, humping his shoulders and ducking his head; looking so uncanny in that dark weird place, he made me think of witches and goblins.

The last time I saw him was late in October. He followed me to the edge of the Limberlost, so I turned and made this picture, used as a tailpiece, when his wings were raised for a sweep that carried him skyward to his parents. That season the Limberlost yielded me the only complete series of Vulture studies ever made, dozens of studies of other birds, material for the book "Freckles," more natural history stuff than could be put into several big volumes, many rare specimens and much priceless experience in swamp work, for all of which I acknowledge my indebtedness to Mr. Bolds, to Little Chicken, and to the Deacon.

The following season, having become familiar with the Swamp and therefore indifferent to its annoyances and dangers, I prepared myself suitably to meet them, and went as often as I chose. I hoped this pair of Vultures would return, and I am very sure they did; but finding the only favourable nesting location gone, they moved nearly a mile away, to our farm, where they were investigating a hollow log, when our farmer, not know- 


\section{FRIENDS IN FEATHERS}

ing what they were, mistook them for Hawks, and tried to shoot them.

They speedily left. The next I heard of them a man living five miles east of us sent me word there was a pair of big birds nesting in a hollow tree in his woods, so I went to pay them a visit. Having been unmolested, they had a fine pair of young, almost three weeks of age, when I arrived. The female was the same small, sleek bird; not so timid as she had been the previous summer. The male was the same big, old, scale-encrusted fellow; exactly as I remembered him, so that I am sure as I ever get of anything I cannot prove, that these were Freckles' Chickens of the Limberlost. I even enjoyed the hope that they knew me, the small black horse, and the load of cameras; but very probably that was a case where the "wish was father to the thought."

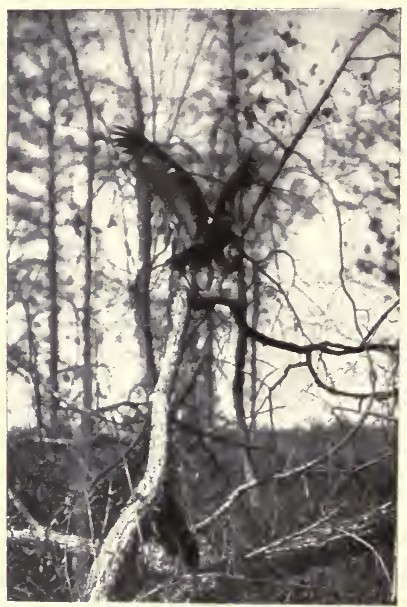

IIIS WINGS WERE RAISED FOR THE

FLIGHT THAT FIRST CARRIED HIM SKYWARD TO HIS PARENTS

136 



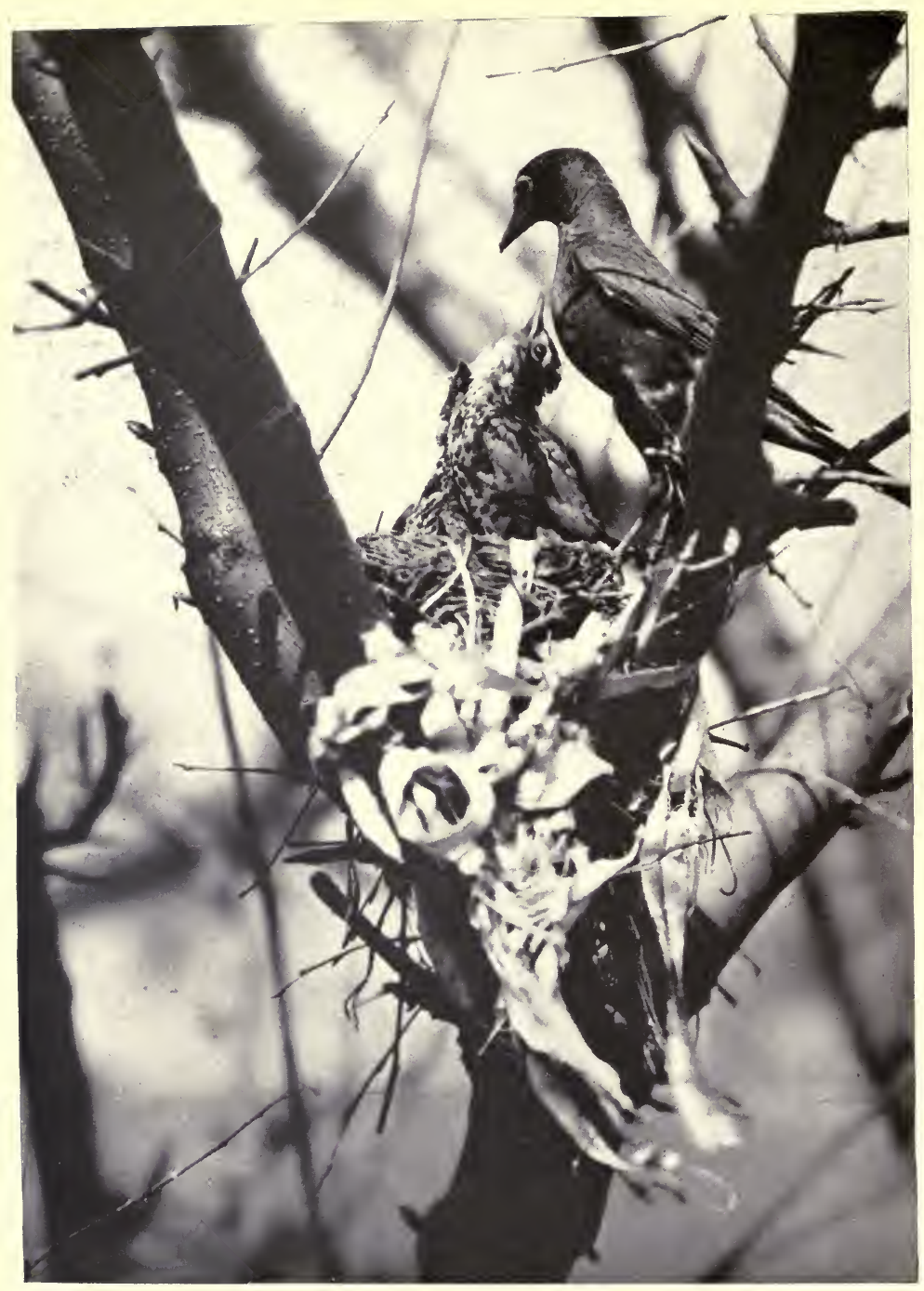

WHEN FATHER ROBIN REGURGITATES 


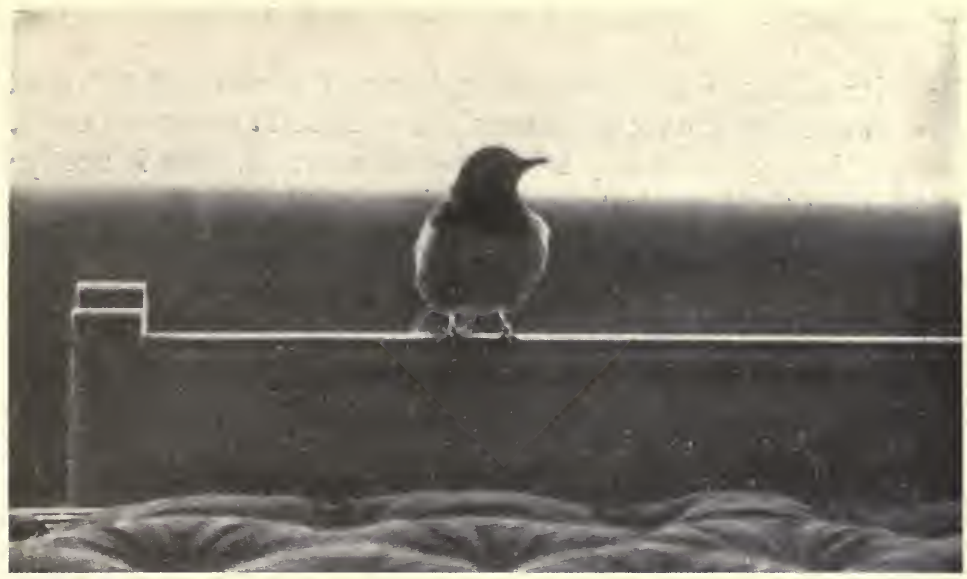

Taken with camera on library table, on February twenty-seventh, through heavy plate glass. Robin on the bench on veranda, snow six inches deep on the ground

\section{CHAPTER XI}

\section{Robin: Planesticus Migratorus}

\section{IN THE DOORYARD}

I LEARNED to love the Robin, when as a child, I sat on my father's knee while he pointed out to me the russet-breasted bird, singing from the top of a cherry-tree during a spring shower, and taught me to mark the accent, to catch the exquisite inflection of tone as the happy bird sang: "Cheer up, dearie! Cheer up, dearie! Cheer up! Cheer!"

He told me the story of the Robin that tried to minister to the dying Saviour on the cross staining its breast with sacred blood; of how Christ blessed it and commissioned it ever to be the friend of mankind, always to sing to him of good cheer; of 


\section{FRIENDS IN FEATHERS}

how its eggs are blue-green like the sky above the sea, and how to this day the Robin is man's good friend among the birds, because he would scarcely have fruit crops at all, were it not for the insects the bird destroys. During the story my eyes were watching the dark gray bird with its bright breast, singing through the rain the words I could plainly distinguish: "Cheer up, dearie!"

We were taught that a blessing came to any home with the Robins so every inducement was extended to them to build with us. The first year in a home of my own there were no Robins; by the second my overtures were accepted. Since, every summer they are sure to build in the orchard, often in the vines on the veranda and several times where the logs cross at a corner under a porch they have set up housekeeping.

Always we have extended to them every protection and assistance in our power to give to a bird. The past year we had a Robin in the wistaria vines on the veranda. The birds in feeding perched on the logs not a yard from me or flew back and forth across me as I lay in a hammock within a few feet of them. Another pair will find their last year's nest in the mulberry west of the Cabin, only needing relining when spring comes again, while a third can return to the elm by the back porch.

But it is about Robins of a few years ago which I tell, as these pictures are of them. One summer nine years past a pair of young Robins established themselves in a plum-tree close the back door. They had been hatched the previous summer, so were shy and nervous as birds in their first brooding often are. They attracted my attention by their timidity. I cautioned my household to be especially careful in no way to alarm them. I noticed the male bird at the well one day drinking water from the boards.

Soon after he left I set out a dark, shallow baking-pan, filled 


\section{ROBIN}

it with water and instructed every one going there to see that it was freshly filled. The table crumbs were scattered by it so in a few days both birds drank and bathed there and eame regularly for food. They did like bread and milk and hard-boiled egg. It was while they were bathing and feeding that I especially noticed the male. He was the biggest, brightest, most alert and knowing-looking Robin I had ever seen, while I had been accustomed to them almost every summer of my life. Immediately apples and fruit were added to his diet, suet and scraped beefsteak, grubs spaded up in the garden and anything I thought him likely to eat that was not salty. It was amazing the way that bird grew, and he carried food to his mate until she was above the average Robin's size.

He not only developed in body, but he grew strong in every way, for no other Robin could equal his vocal powers. His song was the same old song of cheer, but there was a depth of volume, a mellowness of note, a perfection of accent that surpassed other performers of orchard and wood. He seemed to know it. He would perch on a peach-tree near the plum and sing his opening strain. Then he would pause as if considering it. Then he would repeat it and rise a little louder, fall a shade deeper, and cling to his notes until he came to the final, always abrupt. He would think it over again, then begin anew and when he had repeated his strain five or six times he was in a frenzy of ecstasy with his own performance, stretching to full height, his throat swollen, his eyes gleaming, every muscle tense, so that in all birdland there was but a faint breath of harmony to surpass him. When the rain fell, as if he knew it a blessing, a thing for which to be thankful, with the drops dripping from his gray coat he lifted his golden throat and sang and sang incomparably.

In only a short time he learned that when the pump was used the water would be fresh and cool; so when one started toward it 


\section{FRIENDS IN FEATHERS}

he went along and perching on a bush close by awaited his treat. Then he learned that when the master of the house came, soon after would appear the table scraps, so he went to meet him greeting his appearance with an alert: “Kip, kip, kip! Cut, cut, cut!" Neither was he long in discovering that when I walked through the orchard and pottered among the plants and flowers he always got a piece of ripe apple, fresh fruit, berries or a grub or worm; so he went with me and talked to me all the way, flying down for what I gathered for him. They raised two broods on the premises and when family cares were over and the remainder of the Robins and Bluebirds betook themselves to the deep wood for vacation and moulting, they went along, but with the difference that every day, sometimes several times a day, they came winging in from the forest to eat and bathe at the well. It seemed to me that they were with us two weeks after all other Robins had migrated in the fall.

During the winter we wondered about them, speculating on whether they would return, and if we should know them. We were uneasy, for we had laid the foundations of a new home. There would be workmen and noise all summer, so I sadly prophesied that we should lose our birds and have to begin all over again. Late in March the Deacon called me, and as I stepped to the back door, before he could speak I saw a Robin at the well, our big bright bird beyond all question. We hurried to put out his waterpan and food: so while the foundations of our home were settling, he laid those of his in the plum-tree again.

But the noise of the carpenters within a few feet of him drove him away; so he went down in the orchard, and set up housekeeping on an apple branch that did not seem to me much farther from the building. His music was even finer in quality, while his disposition was friendlier than the year before. All the workmen around the cabin were under special instructions con- 


\section{ROBIN}

cerning him. Just as I thought his brood would come off safely, a new man was put on the gang. I did not notice his arrival from the house in which we lived on the premises, but seeing that they were running a veranda on the new house close the Robin's tree I hurried out for his protection only to meet him coming after me, screaming frantically, "Kip, kip, kip!" and uttering sharp alarm cries.

I ran, but it was too late. His branch had brushed across the face of the new workman as he set up a pillar, and whirling, with one stroke of his hatchet he slashed through a limb as thick as his wrist which fell to the ground, tearing off the nest and breaking the eggs. Any member of that gang is qualified to tell what I say and do when angry. Then I was sure we should lose our bird, but he went to the front of the lot and located thirty feet high in a big elm coming to the well for food as usual.

That gang was broken to birds, however, for a few days later the foreman came to the door, grinning in confusion to tell me that a pair of Pigeons had built a nest at the base of a big chimney, that turned and twisted its way to completion, carrying drafts for five fireplaces, and at a last turn, where it cleared the attic rafters, the birds had built and laid their pair of beautiful eggs. They were brooding and he did not know what to do.

"Let them alone," I said. "Don't allow a man to touch them."

"But we are going to shingle," he protested.

"Then shingle!" I retorted. "You will be fifteen feet above the bird."

"But the siding and shingling of the upper walls come next," he objected. "Shall we pen them in?"

"No, go on with your work as if they were not there. When the walls are enclosed there will be three window openings, and 


\section{FRIENDS IN FEATHERS}

if you come to them before the birds are gone you can leave out a north one nearest the nest."

A day or two later one of the men told me a pair of Wrens was building over a dormer window upstairs, so we found a way to give them access to their nest also, after the building was enclosed. Two families occupied our new home before we did.

The following season, on the twenty-eighth of February, I was amazed to hear my Robin calling me. I looked out to see him on the grape-arbour peering into a back window. It was a moderate day, bright and sunny, but there would come a heavy freeze at any time. It was five weeks earlier than any other Robins would arrive so I did not know what to do. Food and water were hastily set out and he ate and drank as if very hungry. By mid-afternoon the clouds gathered, a northern wind swept down and snow began to fall. Poor Robin did not know what to do and we did not know either. At last I saw him peering around an old summer kitchen left standing on the back of the lot; that gave me an idea.

I hurried down, opened a small door in the loft above the door below and shoved back on the rafters a warm box covered with an old coat and hay. I barely had it fixed when the storm broke in fury. The bird went into the loft. His droppings proved the following morning that he had perched in the box as I had hoped. Two days later his mate came. They took possession of the premises and lived in the shed loft at night. Long before the snow was off the ground they were pulling last year's dead dry grass-blades from underneath it, and on the sunny side of each little hummock working to pick off mud for plaster.

They located where the logs crossed at a corner over a back door and built this nest. A finer piece of Robin architecture would be difficult to find. There were no twigs to be used. They could not find any. All the material they had to draw on 



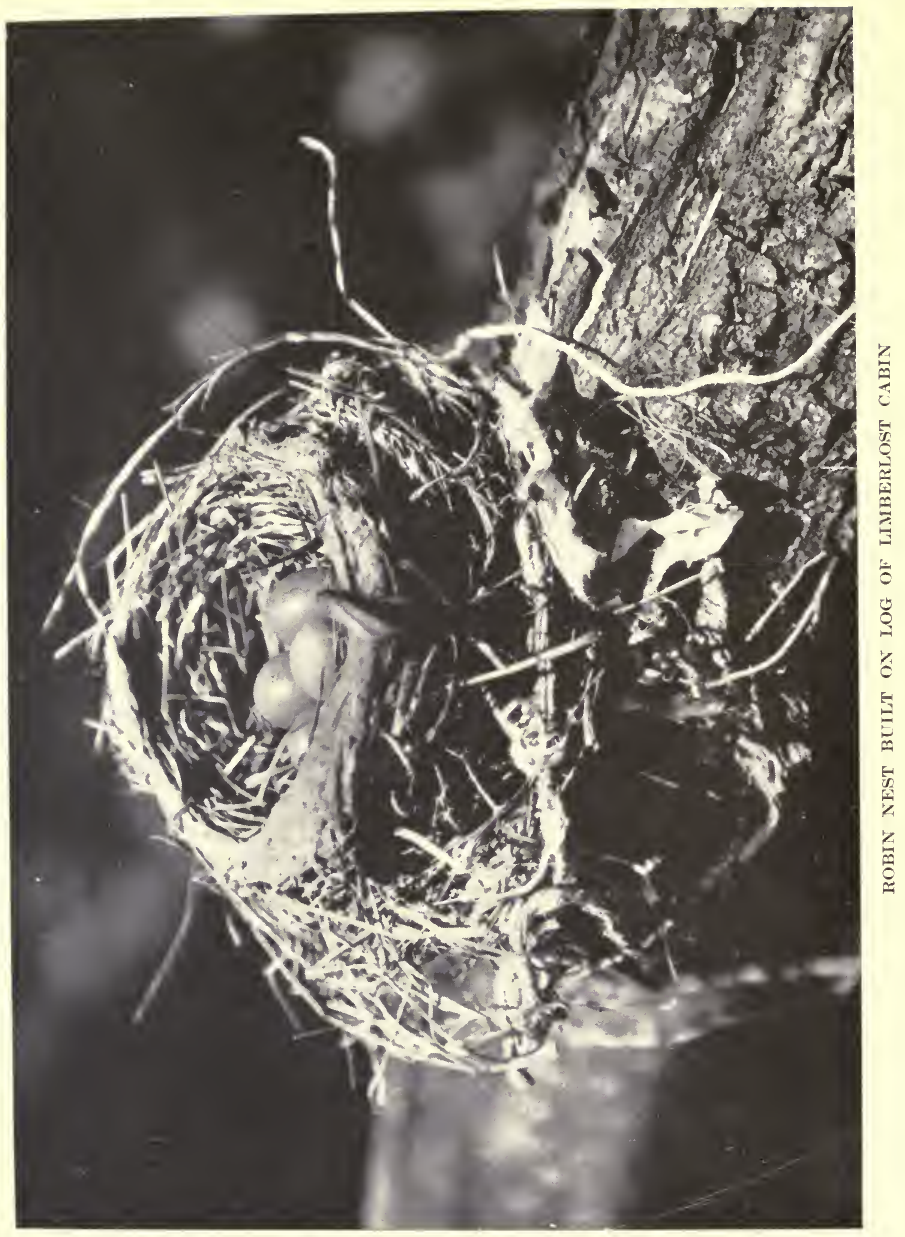




\section{ROBIN}

was a very little mud and dry grass-blades. The eggs were laid, Mother Robin was brooding before the remainder of her kind had arrived. I kept out a supply of food, as there was none for them to find, and everything was going well.

Robin sang his heart out from the old roof and sunny spots to the south, while his music never sounded so mellow and fine as when few other birds were singing. February might bluster and rave and March empty her watering-pot in icy showers over us, but first in the morning and last at night we were cheered by the voice of our loved Robin.

One morning he came on the grape-arbour in a tumult of excitement, startling me by his alarm cries. I hurried out, but could see nothing to frighten him. I looked at the nest, but his mate was not there. He kept up his flight and cries. Then I took a step-ladder and examined the nest. The eggs were cold, but there was no sign of an $\mathrm{Owl}$ or violence of any kind.

Then I started to the shed, thinking some harm might have befallen her there, and ran across a little heap of bloody bones and gray feathers, while our neighbour's cat slinked away licking her chops. On our premises she had dined off a bird that money or time never could replace. I do not care for cats.

For a week Robin mourned his mate, searched and called for her until we were almost distracted with him, then one day his song piped up again, for the south had sent his kind and he was courting. He really seemed apologetic when he flew down on the lawn with his second choice and introduced us. No wonder! She was a young thing, she was bedrabbled, while she was one of those foolish, jumpy, nervous birds that never will act with sense, because they have none.

If ever a male tried to dominate the choice of a location it was our Robin. I gave up long before he did. He carried grassblades to the old location. Oh, dear no! she never would enter a 


\section{FRIENDS IN FEATHERS}

veranda. He tried the wistaria. Mercy! she would be killed if she went near it! He dilated on the plum-tree. Shocking! It was entirely too close to the Cabin. Then he took every tree of the orehard and the big forest trees in turn, carrying grass-blades, and working industriously. But no! She was a deep-wood bird; she was not going to be coaxed into any such locations.

Sadly he and I watched her select a big hickory across the street and then begin her nest. I honestly do not think she got much help with it, while it is the truth that Robin's song was a failure in comparison with his former efforts. The dear bird loved us. He knew his home; it seemed to me, even after the new mate was brooding, that he bewailed his first love and his old location. He did his duty about feeding but he always came to me to seareh for food, to bathe and to sing.

The following year it was on the twenty-fifth of February, three weeks to the day before the other Robins arrived, that he announced himself at the well. Again we hurried to meet and weleome him. No mate was with him and none arrived later. He was still growing and was an immense fellow. Shortly after his arrival he was attracted by a long-haired white spaniel, a new possession of Molly-Cotton's, and he seemed unable to decide whether it was a dog or cat.

Soon I noticed him perching on the back of an oaken bench that stood on the front veranda, directly across a big six-foot square plate-glass window. I sat at my desk a few feet away while he settled there looking at me. He came more and more frequently, staying longer each time. At last a heavy snow fell, covering everything several inches deep. Then he adopted the bench back and for an hour at a time would pereh there.

Our movements did not worry him in the least and unless the little dog jumped to the deep seat of the window inside he seldom took flight except for food and water. One day he sat motionless 


\section{ROBIN}

so long, while I waited for an idea, that one other than that for which I sought came to me. Why not take his picture?

There sat that blessed bird, now of four long years' acquaintance, through his love for and trust in us, our guest three weeks before any of his kind had come; while the fence in front and the logs of the veranda railing were covered with three inches of snow, the ground with six. Surely that was a picture to materialize as well as to live in the heart.

I polished the glass to the last degree inside and out, set a camera on the library table, then focussed on the bench back. The shutter was set at a bulb exposure, the long hose attached and the bulb laid on my desk, where time after time I made exposures on him. I had to work against strong light, for there was the snow outside, while his face and breast were in the shadow, but I did my best. I had thought he remained motionless much longer than he did, when it actually came to counting off time in seconds. I could not secure as long an exposure as I wantedhe would turn his head, ruffle his feathers, or draw up a foot to warm it. But I made several good pictures that were precious to all of us, for there was the window-seat cushion for a foreground, the oak bench outside the glass for a perch and three inches of snow in the distance on railing and fence.

And still he awaited the coming of spring and his kind, while no mate came. One night the Killdeers reached the Limberlost at two o'clock; the following the Larks, then a few days later came the Robins, so again our bird went courting. For two days we missed him, and were growing more anxious than anyone who has not had a like experience could believe possible; then he came home, and what a bird he brought with him! He was so proud he almost perched on my head as he swept the length of the veranda calling me. I turned to welcome him and there was his mate. 


\section{FRIENIDS IN FEATHERS}

She was almost his size, sprucely dressed, and thank heaven! open to conviction. I could see it in her big, wise eyes, the alert poise of her head and her willingness to follow his lead. Before the day was over she was helping carry twigs to the wistaria, and in an incredibly short time she was brooding, while Robin was back on the bench looking in the window. He seemed content and happy as a bird could be. I guarded faithfully with him, no accident befell the nest, for its brood left safely. 'Then they changed to a hickory in a small grove by the back porch and nested again.

They stayed late that fall, and the following spring came early as usual and together. Again they built in the wistaria, using the old nest for a foundation, and again they brought out a full brood. For a second nesting they chose the top of the martin box on the windmill, but I think they were sorry, for the Sparrows tormented them constantly. That year Robin seemed rather sluggish in his flight, he sang much less and with nothing like his first spirit and intonation. And no wonder! For five years the precious bird had homed with us. All the care we could give him was freely his for the love we bore him. I often wondered what I would have seen could I have followed him south; but however kind everyone would be forced to be to him, I always shall believe he loved us best on account of those early migrations, often made alone.

The following year we had swarms of Martins on the windmill, Bluebirds in the bird houses, Song Sparrows in the honeysuckle, and Robins in three different trees, but tragedy or old age had done its work, for all that spring we listened in vain for the voice of our dear bird.

Among these newcomers one hen was remarkable. She built early in an apple-tree outside the music-room window. The tree had been struggling with seale for several years; that winter it 



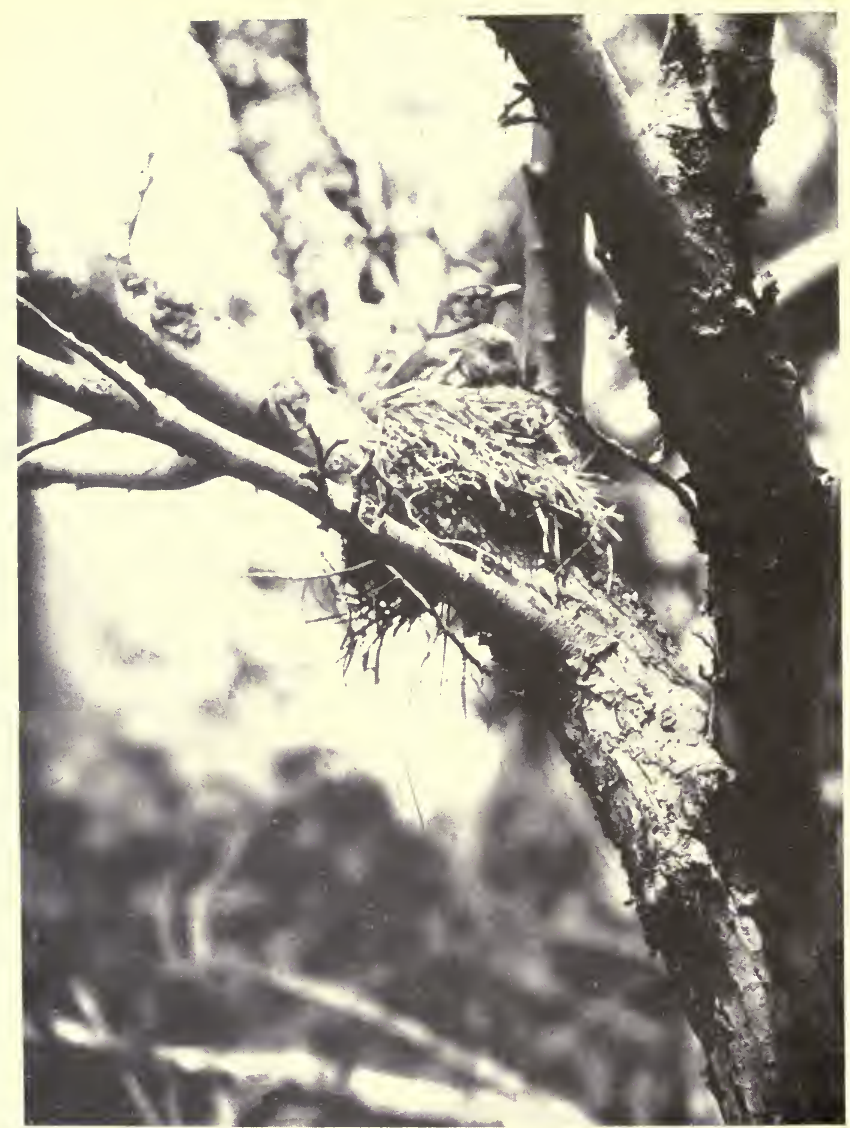

THE ROBIN THAT SELECTED A DEAD TREE, THEN BROODED IN THE RAIN 


\section{ROBIN}

succumbed. The bird builded in all confidence, nearly fifteen feet from the ground, at the branching of two large limbs. Not one leaf opened to shelter her. One of those early spring days she baked in the sun, the following she chilled in a skift of snow; how she breasted one rain always has been a marvel to me.

The tree stood outside a French window and from the slope of the ground, the nest came nearly level with the face of a person standing inside the window. The rainfall began on Monday morning; from then until ten o'clock Thursday there was not one daylight hour during which it did not rain, from a sprinkle heavy enough to detain the bird to keep her nest and eggs dry, to a deluge that forced her to stick her beak straight up and gasp for breath. During all that time not one of us saw that bird make a movement to leave her nest nor did the male bird come once to feed her or relieve her long siege of brooding; from Wednesday morning on some of us were on watch almost constantly.

I thought that the mud plastering of the nest would dissolve, so that it would wash away from under her. I thought her eggs would be chilled so that her young would be lost; while in the heaviest downpour I truly thought she would drown on her nest or perish from hunger.

We seriously discussed trying to wire an old umbrella over her or to fasten a box above the nest; but we feared that any shelter we could arrange before her eggs had quickened to bind her to the nest, would drive her from it; so we watched, marvelled and lamented, but did nothing. At ten o'clock Thursday the rain stopped, the clouds scattered, then the sun shone. Riley wrote of a bumblebee so laden with sweets that it "staggered" as it flew. From long continuance in the same position during all those hours of cold drenching, and hunger, our Robin staggered when she finally arose from her nest, shook her wet wings, uttered the Robin tribal call, and attempted flight. I was watching, so I 


\section{FRIENDS IN FEATHERS}

saw her miss the branch of a nearby plum-tree, where there was good foraging, and fall among the leaves below. There she rested for a short time, then reached the branch she had first started toward. From there she wavered to earth to feast on angle worms until my next fear for her was that she would burst. Then her mate came to her and they talked it over. He went to inspect the nest but did not enter it. Soon the mother bird began brooding again. She left the nest more frequently than usual that day; the following she seemed quite recovered from her rough experience. Three of the eggs hatched, so that only one bird was lost, while I cannot prove that it was on account of the storm.

That mother Robin stands monumental to me, as the most heroic of all mr feathered friends; because I am convinced that she brooded without once leaving her nest through cold April downpour, from Sunday night until ten o'clock Thursday; quite, if not more than ninety-four hours. Human mothers are not the only ones who sacrifice personal comfort for their young.

Another dearly loved pair of Robins built later in a mulberry beside the well. Each summer this tree threw out a mass of tender shoots, each winter froze them, each spring the gardener cut them back to live wood. The mass of stubs made most inviting nest locations for the birds, so attractive that a pair of Blackbirds also elected to settle in that particular tree. The Robins lad begun building first, I assisting with rags, twine, tow and cotton cord. This made building so easy for Mother Robin, that she finished and was brooding before the Blackbirds, scorning my help, had a good foundation. That left Father Robin all his time, which he employed in harassing the Blacklirds, until they abandoned the location and built among the reses on the back wall of the Cabin.

From my mategial the Robins built a big, showy nest, the 154 


\section{ROBIN}

gaudiness of which invited every marauder of air to attack it; but being close the well and kitchen door, we gave it all the protection we could. These birds grew so accustomed to us and so very friendly that they monopolized not only the mulberry, but also the near-by catalpa, birch and sycamore. By the time the young arrived and were able to lift their heads above the rim of the nest, the elders paid so little attention to me that I pictured them repeatedly in almost every attitude assumed in rearing their young.

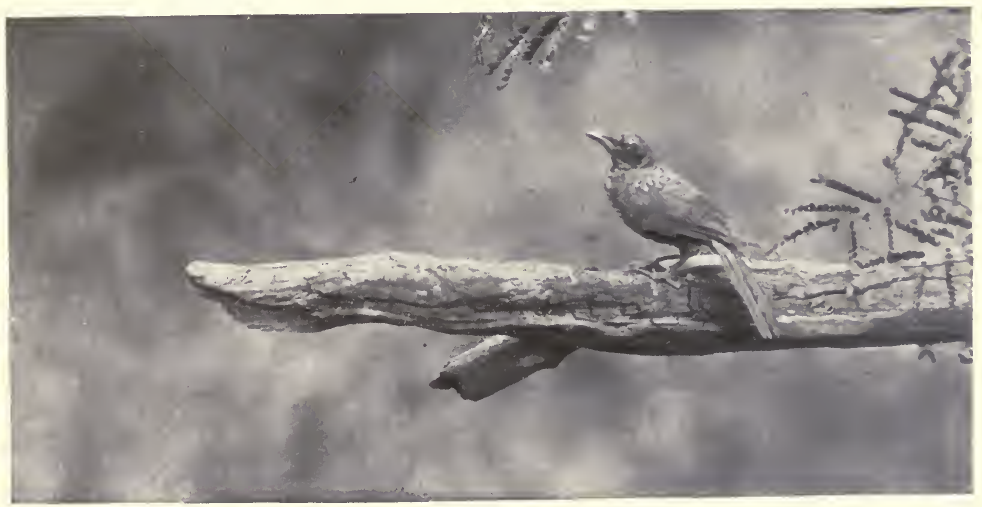

READY FOR FIRST MIGIRATION 
"See yon robin on the spray;

Look ye how his tiny form

Swells, as when his merry lay

Gushes forth amid the storm.

Thank him for his lesson's sake,

Thank God's gentle minstrel there,

Who, when storms make others quake,

Sings of days that brighter were."

- Heir. 



\title{
CHAPTER XII
}

\section{The Purple Martin: Progne Subis}

\author{
IN THE AIR
}

For these I need make no personal search, nor tax the kindness of friends. The Purple Martins come to us. Every year at migration time they sweep up from the South and claim their preëmpted location on the windmill, or in a small bird-house east of the Cabin, on the stump of a dead wild cherry. Sometimes our Wrens leave us. Sometimes our Song Sparrows cross the line and build in our neighbour's pear-tree. The Orioles may locate with us or they may not. The English Sparrows drive away the Flycatchers, which nest so hgh in the big elm we can not protect them. But three standbys never fail us: always we have Martins, Bluebirds and Robins.

Martin headquarters are on the windmill, in a big box arranged for eight families and placed on the north side of the mill under the shelter of a small platform, above A Double martin house which swings the wheel. This 


\section{FRIENDS IN FEATHERS}

makes a splendid location for the birds, sheltered from sun and wind. But it is almost impossible to secure pictures of it, as the camera must always face the strong light of the east, south and west, while the mill is so high that I have as yet devised no way to reach a level with the Martin box. So every day through summer the most wonderful groupings of Martins, circling the mill or perching over the wheel and fan, tempt me but can not be obtained.

At the house on the wild cherry stump I have better luck. It is not over twenty feet high, while a wire brace running from one telephone pole to another passes very close. From the top of a twenty-foot step-ladder a camera is level with the nest and wire, the birds soon become accustomed to it, so it can be worked with a long hose from the Cabin window opposite.

In the year of 1905 , the weather moderated for a few days in the latter part of February, but I was amazed to see one Purple Martin fluttering around the windmill, or perching to rest on the grape-arbour, looking weather-beaten and as if it were exhausted from a long flight. It was scarcely to be believed, but that night the gardener said he had seen it from the stable. A few days later a tenant on the farm told me there was a Martin at his boxes on the same day. This year sharp watch shall be kept so if he comes again, I shall be convinced that the Martins send out scouts to see if their quarters are all right. My belief in this is so strong that last fall I refused to allow their box to be taken down and stored in the stable until spring, for fear a prospector should be sent to see if it were safe, find it missing, and so become discouraged and take up quarters elsewhere.

The flock arrives from the first to the fifteenth of May. The gardener empties their boxes at the first sign of their coming. They swarm all over the windmill and immediately the fight with the dispossessed Sparrows begins. The past year we 


\section{THE PURPLE MARTIN}

boarded up the openings so that the Sparrows could not have the boxes lousy and infested when the Martins arrived. That seemed to delight the Martins, but it in no way discouraged the Sparrows.

From a back porch where a rack was placed containing printing frames on which I was doing the printing of these illustrations I watched a war which I was powerless to prevent. All day it continued. The Martins took possession of the boxes, slept there the first night and began building in a few days. When the gardener cleaned the boxes this fall he said there was scarcely anything that could be called nests - a few dried grass-blades, pieces of strings, rags and dry leaves. There was little time for elaborate nest-building in the strenuous work of holding the fort.

Every time a Martin left a door, in rushed a Sparrow and carried away a piece of straw or string, or threw out an egg. Every time the whole Martin flock left to bathe or go food-hunting, they found a Sparrow head protruding from each door on their return. Then there was a battle royal. Seven times in one day the Martins sent a messenger to a flock occupying a larger house than mine on the premises of Colonel James Hardison four blocks away, air line. Each time the bird returned with reinforcements to the number of twenty, so the Sparrows were ousted.

But if I could do nothing for our pets of the windmill, a mite of help could be given to those of the bird-house on the wild cherry stump. Day after day I mounted the step-ladder and with a bent wire tore out Sparrow nests, until finally the Sparrows gave up the house, locating in a large ash tree on a line with the Martin house, facing it, and only three rods away. The Martins fought valiantly for their nests, but with one exception; they never went to the Sparrows' location and attacked them. On the other hand, the brooding Sparrow would leave her nest, if her mate were not close to harass the Martins, and enter their 


\section{FRIENDS IN FEATHERS}

box to be on hand for a fight with them every time they returned home. The male Martin never brooded, but his other attentions to his mate seemed delicate, constant and tender. When the Sparrows became too aggressive, he spent every minute, when not bathing or food-hunting, doing sentinel duty on the telephone wire only a few feet from his front door. When one considers the tireless flight of the Martin, which seems forever winging the air, one can not help feeling that those long stretches of watching, clinging to the hot wire, were severe punishment.

But like the brave soldier he was, the Martin stood sentinel on the wire while I secured many good pictures of him there; pictures in which the strength of his character shows plainly. Once I caught him when he was watching with forceful determination to guard that nest or die; again when he was gathered for a dart, for even as the shutter sprang he flew like a bolt at his enemy.

One day he proved himself a soldier indeed, by an act of strategy that human warriors have employed since time began. While he was away from home, from some pressure the female felt she must leave the nest. She came to the door and looked all around for him, calling several times, but he probably was at the river, as he returned in high flight from that direction. Failing to call him to guard, after some hesitation the female left, also flying toward the river.

She was not out of sight before the Sparrow in the ash left her nest, entered the Martin house, turned around and filled the door with her head and shoulders. It was only a few seconds until Father Martin reached the wire. From my hammock on the veranda a few feet away, screened by the wistaria, I could see the rage that shook him. He evidently thought it unwise to attack the Sparrow in his nest, so he darted to the ash, perched on the edge of the Sparrow's nest, ripped a big beakful of straw 


\section{THE PURPLE MARTIN}

from it, then with a quick jerk of his head scattered it on the wind. The second beakful brought the Sparrow home in a hurry. The Martin flew back to his place on the wire where he executed a small triumphal demonstration. He plumed his feathers with exaggerated swagger, that appeared exactly as if he were saying: "Oh, didn't I fix you that time!" He sprang straight up from the wire then rapidly settled again; he chattered angrily, though I never before heard him make a sound when on sentinel duty. He taught the Sparrow a lesson, for that was the last time for weeks she entered the Martin box. She would dash at the Martins threatening them outside, but she seemed to have learned that there was such a thing as the besieged retreating and attacking the stronghold of the enemy.

The past year six pairs of Martins nested twice on our windmill. They averaged four, creamy-white, oblong oval eggs to the nest. After the first brood had become full grown and selfsupporting, still they all forced into that box for the night. When the second brood was hatched, and joined the family on wing, they could not crowd into the box, so the elders slept on top of it in a narrow space beneath the platform of the mill. By October, then, our twelve Martins of spring, allowing four eggs to the nest and two broods to the season, had multiplied to more than forty. The Sparrows must have destroyed many, for I never was able to count above thirty at one time during the fall.

However many there were, one thing was sure: they all stayed in or upon that box at night. By sundown they gathered from the forests or the river and began the preliminaries of settling. For full an hour they chattered, jabbered and circled in wide sweeps of flight around the mill. At first they would fly in a wide circle nearly from sight. Then narrowing by almost imperceptible degrees after an hour, sometimes longer on wing, they would sweep closely around the box; at last one would enter. 


\section{FRIENDS IN FEATHERS}

After that one or two deserted the circle for the box at each round until the last bird disappeared.

I am glad to own the pictures I have of them. The coming summer, however, a box must be arranged with a hinged roof so the young and eggs can be reproduced. One box might be placed on the west side of the mill so that a focus could be had on it from the barn roof.

So far I have not been able to do what is possible with Martins. I never shall unless some way is invented to exterminate English Sparrows. But I have succeeded in enticing Martins to build on our premises, affording them sufficient protection to bring out large broods. With all that flock to clean pests from our fruit trees and sift insect plagues from the air with their queer little sieve-like throats, we were almost free from mosquitoes, and what a fruit crop we had! Summer life at the Cabin would not be complete without Martins. I like to hear their morning chatter, to watch their evening flight, while the twitter with which they perform the business of living is all-day company for me.

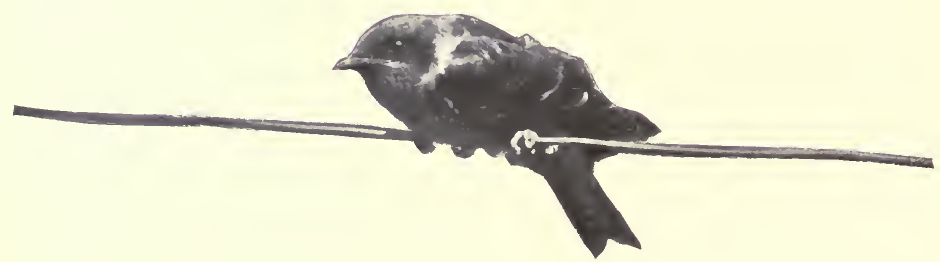

"He spent every minute, when not bathing or food-hunting, doing sentinel duty on the telephone wire" 



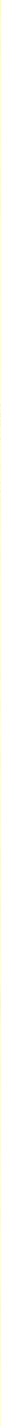




\section{CHAP'TER XIII \\ The Belted Kingfisher: Céryle Alcyon}

IN EMBANKMENTS

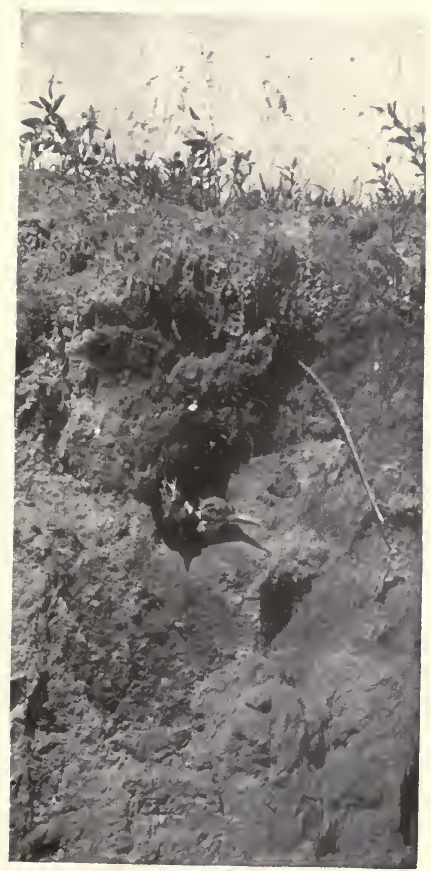

WAITING FOR LUNCH

As THE cashier pushed the amount of my check under the wicket, Mr. William Hale, the bookkeeper, turned from his desk, touching the tips of his thumbs and first fingers in an oval, as he asked: "What does a hole shaped so, and running six feet back into a solid embankment, mean?"

"Is the bottom of it like this?" I questioned, picking up a pencil and drawing a line.

"Yes, it is," he answered.

"Then," I said, "it means Kingfishers. The middle curve is formed by their breasts and the side tracks by their funny little crippled feet. Where did you find a hole like that?

"Found it on my farm while taking Helen and Mary for a walk yesterday. It is in the back wall of the old pit from which the Grand Rapids people took the gravel for the railway." 


\section{FRIENDS IN FEATHERS}

"You need half an hour's outing," I suggested, for the gravel pit was only a mile away, while my horse was at the door. The cashier happened to be the head of my family, so the matter was easily arranged. Mr. Iale and I at once drove to his farm.

The spot was beautiful, a fine place for birds of all kinds. Gravel for two railroads had been taken from one small hill, the presence of which in this stretch of low country was difficult to explain, for on the east lay the river, south the Limberlost, west the big ditch draining it, and north more swampy lowland. A basin had been shovelled from the main bed of gravel, then veins running through it in different directions had been followed up as far as pay dirt was found. Heary rains and drainings from the swamp had transformed these into a small lake and eanals. As this happened twenty years ago, the high parts were covered now with tall poplars and maples, the low with a beautiful fringy-leaved variety of willow, the canal and lake surrounded by cattails, bullrushes and tall swamp-grasses, while everywhere there grew luxuriant vines, or almost impenetrable thickets of wild rose, button-bush and all kinds of swamp underbrush. The river was only a quarter of a mile away while solid swamp covered the intervening space.

The back wall of the old pit was twenty feet high facing east; nearly a foot and a half from the surface was the opening which had attracted Mr. Hale and his little daughters during their Sabbath walk. We cut a willow to measure the tunnel, finding it to be six feet deep. We threw light into it with a pocket mirror, but could see nothing. Mr. Hale was certain that the opening had not been there the previous week, as he had been at the pit much of late, ostensibly entertaining the children, in reality, from the number of locations to which he led me, hunting bird-nests for me. I was sure the work was fresh, for a small heap of sand and gravel that had been pushed from the 


\section{THE BELTED KINGFISHER}

excavation lay directly beneath, not yet spread by wind and rain.

That a bird could have drilled such a tunnel seemed absolutely impossible, for the bank was hard clay, thickly intermingled with gravel and sand, baked by the glare of the sun from earliest morning until night. Above the opening meadow-grass waved, beside it alders and willows grew, while beneath, where the last of the gravel had been taken out, flourished a large and prosperous frog-pond. One had to creep around the edges of this pond clinging "to the willows," in reality, as well as to dig in with the toes to climb to the location. We tried showing a clear shaft of light into the far end of the tunnel, but failed to see anything except that there was a turn having a still larger opening made to the north. So we gave it up, but Mr. Hale consoled me quite by pointing out the nests of a Cuckoo and a Summer Yellow Bird, while I found the locations of a Robin, two Catbirds and a Purple Finch.

Work on these nests took me back to the pit daily. For three mornings I climbed to the opening and with a hand-mirror explored its interior, but to no avail. It was May; every day I found new nests here; Bob added to his forty a mile farther east; I was working on the series of Black Vultures in the Limberlost, calling on them each day and taking their likenesses every third day, also visiting daily half a dozen widely scattered Cardinal nests for the illustration of a book. Every day photographically possible, I was in the woods early and late, stopping at absolutely nothing that stood in the way of my work; you well may believe with such richness of material on hand, there was no time for anything that seemed unpromising.

But one day, two weeks later, when passing the embankment. a Swallow came from the opening and flew away. Immediately I climbed up, throwing in a strong ray of light with a large 


\section{FRIENDS IN FEATHERS}

hand-mirror, to search the back of the tunnel. As I was despairing, there was thrust suddenly into the light a big scarred beak, the biggest eyes I ever had seen in the head of a bird of that size, and a flaring crest. The figure appeared so startling as it flashed sharply on my vision that I jumped until I dropped the mirror, sliding down into the frog-pond. But I did not mind that. I had a brooding Kingfisher, the bird of ancient mystery, an object of tradition in all time; whether eluding naturalists of Greece, controlling the weather of Italy, or driving away evil luck and devils in Germany. I confess the brooding bird appeared like a devil to me back there in the dark, while as she rushed from the nest flying toward the river, the rattle she rolled was a sound as uncanny as I ever heard from the throat of any bird, save only the Loon.

What to do was the question. Go after a man and have him dig in to the back of the nest? That would give a picture of the eggs, but no doubt destroy the nest and drive away the birds. Wait until the young hatched and try for a picture of them? That seemed more likely to yield the best results, for surely when the old were feeding they would not desert the young, even if the nest were opened at the back. Then the babies could be pictured while the old ones were away, carefully replaced, and then, too, there was every chance, that with set cameras, shots at the old birds could be taken as they entered and left the nest. so I decided to wait. That day the bushes were carefully straightened and my tracks covered when I left. Also arrangements were made with Mr. Hale's farmer, plowing in the adjoining field, to watch the pit, and drive away small boys.

After that I haunted the location. I was there every day. On a morning of the second week of June, with my mirror I caught two little Kingfishers peering into the light. Then I went after help. The earth was so hard that when a big strong 


\section{THE BELTED KINGFISHER}

man set a shovel on the spot we had measured then came down on it with his foot, it curled up as if made of lead. We had to bring another and use a hatchet for most of the work. We cut an opening into the tunnel, six inches from the turn to the nest, fitted a shingle to cover it, trimmed a piece of sod to fill the hole so that it could not be noticed from the top; thus I had free access to the young. The old birds never knew it. On their return they entered the tunnel without the slightest hesitation.

I always waited until their morning feeding was done. As they have long, tedions waits on stumps and dead limbs above the water to catch the crabs and minnows which form the greater part of their diet, and always utter their rattle on starting from the river to the nest, there was plenty of time to work between their visits, then drop the young into the nest and cover the opening before the old ones arrived. The regurgitations proved fish, clams and crabs to be the staple of diet, though there were a few berry-seeds, occasionally the striped legs of a grasshopper.

The first time I took those babies into my lap I was delighted. They were the quaintest young birds I ever had handled; the first of their kind. No wonder the snowy white eggs of the Kingfisher are so very oblong. They have to be to allow the growth of that enormous bill, for enormous it was, even on the babies. The little fellows had eyes as large in proportion as their elders, crests of blue coming, a tiny white dot before either eye, broad collars of white, steel-blue wings and backs, tail and primary wing-feathers banded with white, and white breasts touched with blue below the crop.

The old birds were exactly like them, save that the breast of the female was russet where that of the male was blue. Perhaps these birds seemed slightly different to me from any others I have worked with before or since, because they did so exactly what I hoped they would do. Still I never have seen any living 


\section{FRIENDS IN FEATHERS}

or pictured Kingfishers with quite such heavy big beaks, such big eyes, such flaring crests. They seemed to me larger and finer in every way; it may be imagination, yet I feel sure they were. You can compare their pictures with others you have seen, then decide for yourselves.

At the first picturing of the babies, I tried twice, securing good likenesses of them. The second time, some days later and near the time when they would be going, I was assisted by Raymond Niller, a young friend of mine who was born for a naturalist. While focussing on these hirds I explained to Raymond that two were a small brood; frequently there were seven and eight in a family. I said to him:

"Wouldn't it be splendid if we had seven in this picture?"

"I don't know," answered Raymond dubiously; "if there were seven, people would get so mixed looking at all of them, they never would see how cumning only two are."

I knew that if I were ever to get snap shots at the old birds, in all probability it would have to be while they were engrossed with family cares. I never worked harder than I did over those hirds. Up one river-bank, down the other, across the swamp and heside the Limberlost ditch I followed them, until I had located fifty spots on stumps and dead branches, from which they fished every day. Then to figure on lighting, where to set a camera, where to conceal myself, whether I had the bird in range or would waste my plate if I made an exposure: these were the next considerations.

Never was luck so surely with me. And never were pictures so due to luck, pure and simple. Of all the stumps and dead branches on which I had seen them perch, who could say on which they would alight at their next coming? It was by the merest chance that I guessed it, focussing mostly on points they visited. There was extra grace granted me because I did not disturb 



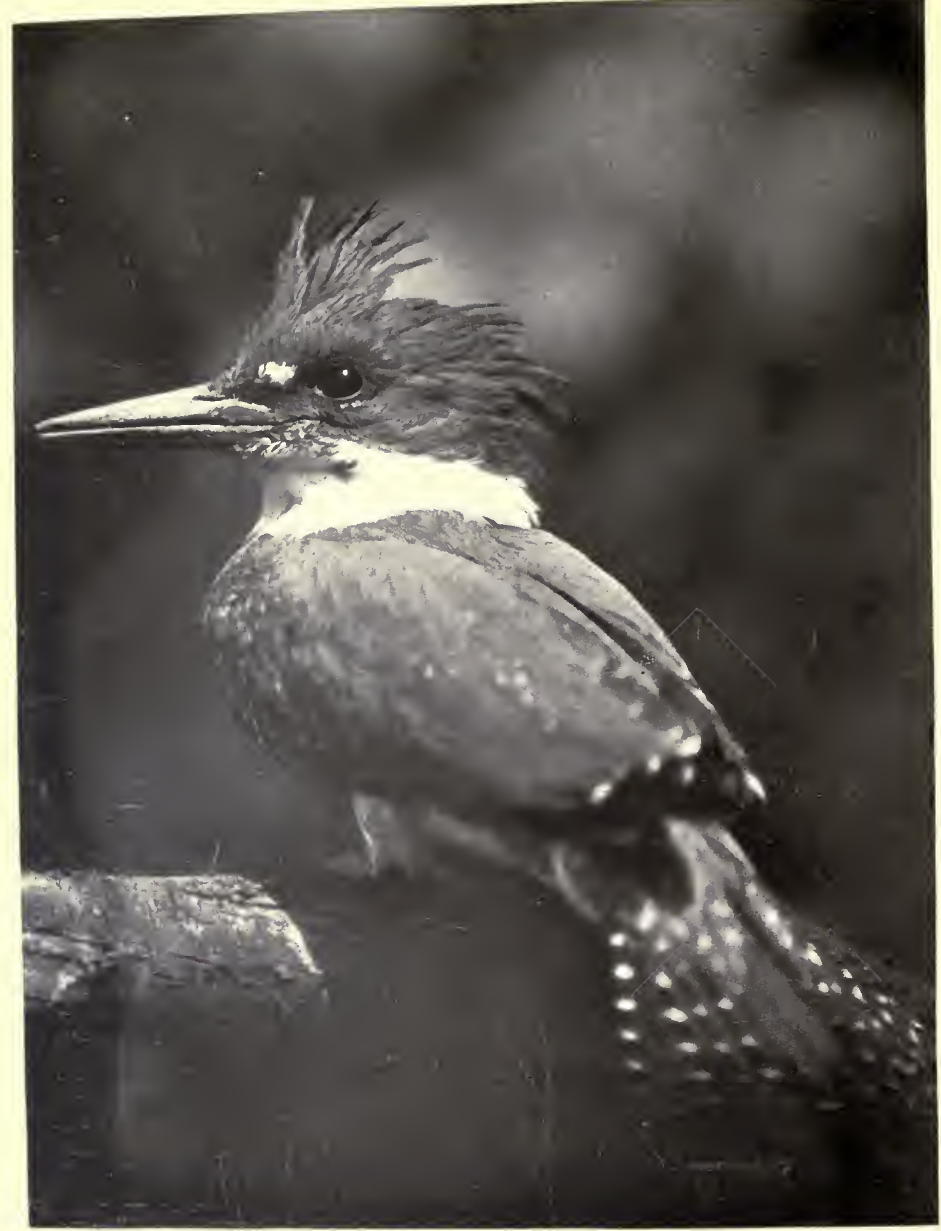

THE HEAD OF THE KINGFISHER FAMILY

"His big beak was scarred from tip to base by contact with stome and gravel in tumnelling" 


\section{THE BELTED KINGFISHER}

the birds while brooding, for as sure as fate I do have best luck when I work in ways that can not possibly injure the birds. Once I got a splendid small picture of the male fishing from a favourite spot on a dead branch above the river. He was near enough and the focus sharp enough to give the detail of every feather to show distinctly the hard work he had done in excavating his tunnel, for his big beak was scarred from tip to base by contact with stone and gravel. He was a noble bird, as he perched in front of my camera. If you want to realize, as you never have before, how amusing the bird caricatures of artists of brush and pencil are, compare some of their attempts at drawing Kingfishers with these living free birds.

I could not make a better picture than one I had of the female, also fishing; but it was on a stump in mid-river that I "capped the climax." I pictured the female there, fishing alone, then was so delighted with the plate that I set the camera a second day to learn if by any chance I could improve it. By one of my special dispensations I took the pair; the female dripping as she came up from a plunge, the male with flaring crest, only an instant before he flattened it to dive.

In the midst of the series came a rare June freshet. The Limberlost arose to meet the river; the water crept up and up until the ditch and river were raging torrents, while all low country was under water. I had not finished with the babies. For three days I worried, the fourth the rain stopped, the sun shone, so I started with Molly-Cotton to drive to the pit. We followed a short route through a lane across Mr. Hale's farm, but we found the water a few inches deep over the road before we reached the Limberlost bridge. Molly-Cotton was dubious, but I was determined, so we drove on to the bridge. Beyond it was a terrifying sight.

The water of the big ditch was running like a mill-race; the 


\section{FRIENDS IN FEATHERS}

flood corered all the fields and swamp save a few of the highest places. It was above the fences, covered with floating logs and débris. The bridge to the private ditch crossing Mr. IIale's land was lodged in the swamp against some tree-trunks. We could not go on, neither conld we turn around. We unhitched the horse, tied him to the bridge, backed the carriage off into the road, and when we thought we were far enough to miss the embankment, tried to turn it. We had not gone so far as we supposed, for it ran down a steep place until the water filled half the bed reaching my best camera.

With all our might we pulled and pulled but could not budge it. Then we corralled some floating rails, laid them out to the running gear, Molly-Cotton walked them and set the camera and my waders upon the seat. Next we brought down the horse, tied the lines to the tugs and to the carriage, held up the shafts, and with Patience's help drew the carriage into the road, where we harnessed and drove back.

On the road leading east from town we held a consultation then decided to drive over to the levee and prospect from there. We turned south at the first crossing, but when we came to the gate we expected to enter, the water was a foot deep. That portion of the meadow lying beside the ditch was all under water, but there was no current. I was doubtful about it, when MollyCotton proposed to put on my waders and prospect. It was meadow that cattle had grazed over, I had driven through it all the spring, she could feel her way before her, so I consented. She put on the waders, pinned up her skirts, took a water tripod, and started. She wore a flaming red waist. In the midst of that pool I saw she was attracting the attention of a cow of the Hale herd. I did not know whether the cow would enter the water, but I did know Molly-Cotton could not hurry on that soggy ground, with those heavy waders; so I called to her to 



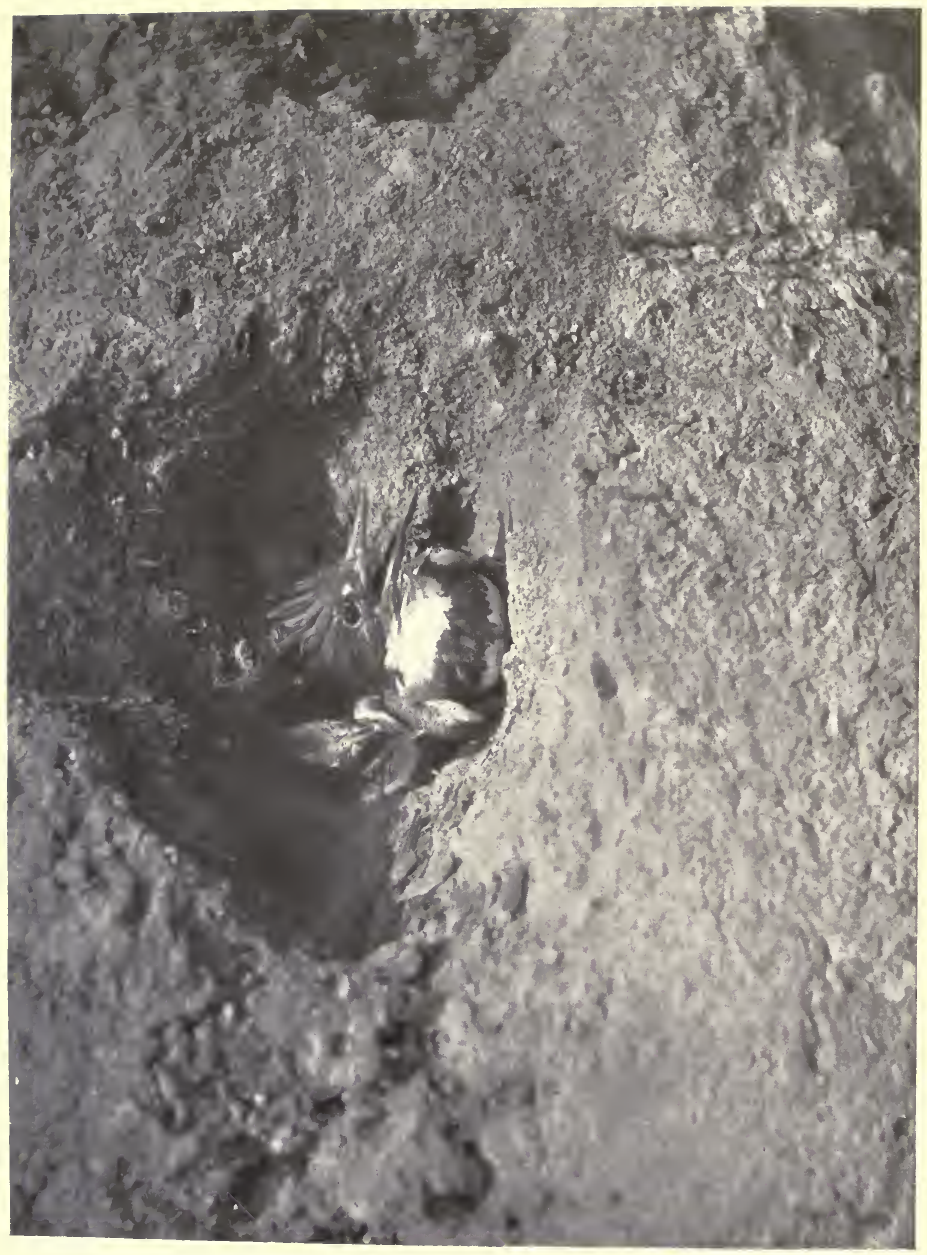

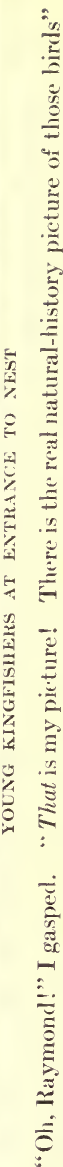




\section{THE BELTED KINGFISHER}

come to me as quickly as she could, that "I saw something" I wanted up the road. Whenever I "see something" all of my" family prepare to capture it. I knew that would bring her with haste, but not frighten her. On came the cow.

"Hurry all you can, Molly-Cotton, I am afraid it will get away! Do come faster!" I urged. She barely reached the gate in time, and only saw the cow when she left the water. She said I had been wise, for she could not have helped trying to run if she had seen it. As the water was within three inches of the boot tops, she surely would have fallen.

Next we decided to drive through, so we started. It was a treacherous journey, for the way was covered with stumps and logs besides the floating stuff. We unreined the horse, which was wise, for half the way across, the carriage was floating, we were on the seat holding the camera, while Patience swam several rods. We reached high ground safely, driving over the ridge, confident that we were on the way to the nest. When we were almost there we came to a ditch ten feet wide and six feet deep, that we had forgotten. I had hoped to reach the nest, secure a picture and cross the corn-field to the road, paying for any damage we might do to the young corn. Here was another full stop. It seemed to me that I could not make that trip back again. I proposed to drive to the south of the ditch, try to swim the horse across, and thus reach the bed of the road from which we had turned back at the bridge. This time Molly-Cotton was dubious. I drove the horse to the water, where he showed his good sense by balking for the first time in his life.

He simply would not enter that water. I suppose the stiff current and the floating logs dismayed him. We had to back out, facing the flood and the cow again. It was rather sickening business. I was glad when it was safely over. After the flood subsided I went to see the place I had tried to drive into. It was 


\section{FRIENDS IN FEATHERS}

an abrupt embankment and where I would have driven the water had been nine feet deep with a stiff current, so undoubtedly the horse saved our lives by refusing to enter.

Ifter we left the meadow the last resort was to drive south on the road until we reached the corn-field, cross that, and thus approach the quarry on its west side. We stopped to take a picture of the Kingfisher, fishing from an old fence-post; with a small camera and long distance it was, but a beautiful thing. Then we drove south. The road lay straight before us while at no place was the water over two feet deep, so we were safe there. We got into the field, then into the quarry, and were overjoyed to find our birds. During our absence they had grown, it seemed, fully a fourth larger, the pinfeathers around the base of the beak had opened, making their faces much handsomer, the plumage lad developed and taken on colour, while the size of their eyes, beaks and crests was comical. We sat on the ground and played with them while we rested from our rough experiences.

We used especial care with those studies of them, as we thought they would be the last. In one of them we felt repaid for all our efforts; but in field work one never can tell, for this was not the end. That came unexpectedly two days later. Passing the quarry with Raymond, I suggested to him that we see if the birds were gone. As we approached, there were the youngsters in the doorway, evidently meditating their first flight. They would crowd up beside each other, half lift their wings, peep down over the edge, draw back, then threaten to try again.

"Oh, Raymond!" I gasped. "That is my picture! There is the real natural-history picture of those birds. Fifty of them made when taken from their nest and set up somewhere are not worth that one! Oh, I must have that!"

"Can't you take it?" asked Raymond.

"I must," I answered, but I did not know what I was at180 


\section{THE BELTED KINGFISHER}

tempting, for that picture cost me the highest price I ever paid for any study, with the exception of one landscape.

"Cover the hole with your hat until something can be found to stop it," I said. Raymond in his eagerness splashed through the frog-pond to do as he was told. A piece of sod securely stopped the opening. Then I figured on the light and where my camera must stand. Of course the location fell in the frog-pond. There was no way to place the camera, so we began carrying stumps and rotten logs to build a foundation. When we had a fairly solid basis we brought rails from the fence near by, laying them lengthwise and then across until we had a solid platform above the water. Then I set up my tallest step-ladder, placed an eight-by-ten camera on top, focussing on the opening. The camera was exactly right, so I put in a plate, attached the sixtyfoot hose, tossing the bulb on the embankment.

Then I went in front, set the shutter at a snap, and climbed up to remove the sod. Raymond crowded close behind me to help. We broke into a colony of digger wasps. They swarmed all over us. Raymond had one on his ankle, also on his arm. I had one on my arm and one down the back of my neck inside my linen collar. I do not remember that anything ever hurt me more. It was the middle of June, our time of most intense heat; I had worked carrying rails and logs until my blood was overheated, while the sting was on my spine, close the base of the brain. I was so paralyzed that it was some time before I could move to doctor Raymond with wet clay.

I sent him into the willows in front of the nest, gave him some lunch and water, telling him to sleep or do anything save make a movement. If he happened to see the young coming he was to signal me. Then I went up on that embankment, lay down, hung my chin over the edge and fixed my eyes on the tunnel. Fifty times the youngsters came close enough that I could catch 


\section{FRIENISS IN FEATHERS}

the gleam of their bills, but seeing the camera they retreated. Many times it seemed I should have to give up because I could not cnclure the punishment. Like a mustard plaster that sum poured down on my shoulders and arms. I felt as if I were being blistered, and I was. Fach upper arm and the tops of my shoulders above my heavier clothing were burned into patches of water hlisters as large as my hand, while I can not tell how those waspstings throbbed and ached.

It was two and a half hours by my watch; I was almost insensible, when a faint whistle from Raymond recalled me. I looked down, snapping on the instant, and secured the coveted picture. This in connection with the two fishing pictures of the grown birds are the only real, natural Kingfisher pictures I have ever seen. I could searcely pack my camera and return to the Cabin. I was red as red flannel, long ago perspiration had dried up, while my flesh burned as with fire. I got into the bath-tub, turned on hot water and took a Turkish bath until perspiration started again to sweat the heat out of me. Then I dressed my blisters and went to bed for the remainder of the day. But never since have I been able to endure the same degree of heat for that length of time.

Whatever it cost, it was worth while. The picture is one of my finest, also I got some mental impressions on that day, of the swamp in the cuarry, and across the road, and of the line of the river, which I now could reproduce to the least detail. I conld catch every breath of movement among the willows and poplars. There were water rats riffling the pool, and snakes weaving among the grasses. All birds of spring were busy everywhere. The Red-winged Blackbirds, there were myriads of them, seemed especially to delight in swaying on the rushes and splashing in the water. It appeared to me, up on that embankment, in the mereiless heat, throbling with wasp-stings, 


\section{THE BELTED KINGFISHER}

burning with thirst, blistering with sumburn, that those provoking birds took pleasure in bathing with exaggerated slop and splash. For one insane moment, after the shutter closed, I had an idea of throwing myself into that pool and splashing also. Then it came to me that in my condition to enter cold water meant death, so I waited and endured the further punishment of the hot bath, or I would not to-day tell the story of my friendship with the Kingfishers.

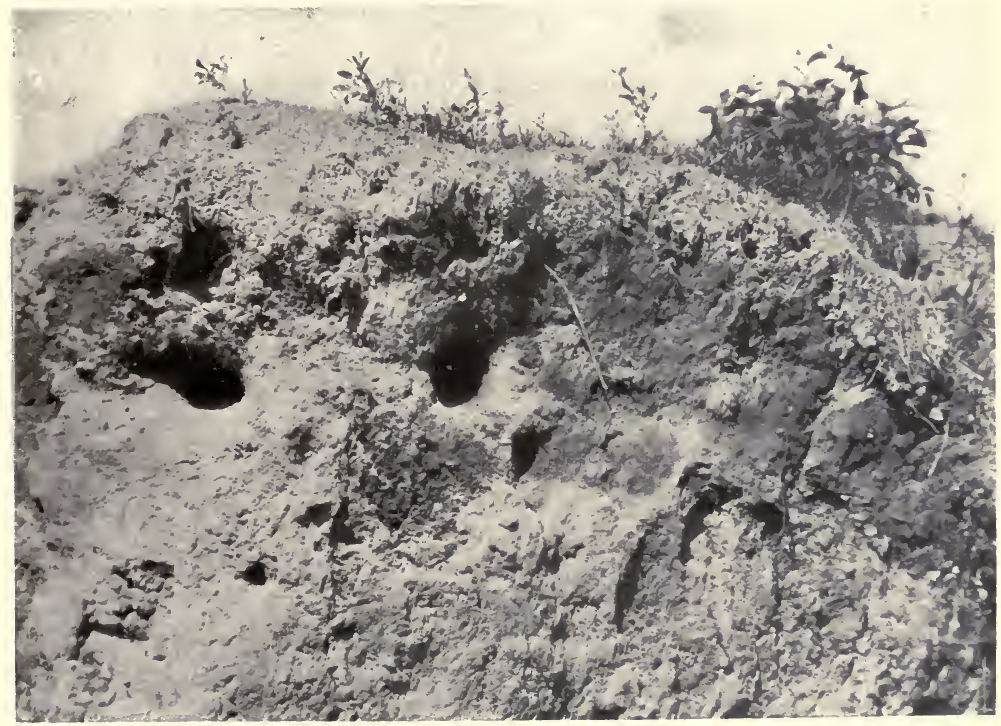

KINGFISHER FLATS 
"He laughs by the summer stream Where the lilies nod and dream, As through the sheen of water cool and clear He sees the chub and sunfish cutting sheer.

His are resplendent eyes;

His mien is kingliwise;

And down the May wind rides he like a king, With more than royal purple on his wing."

-Thompson. 



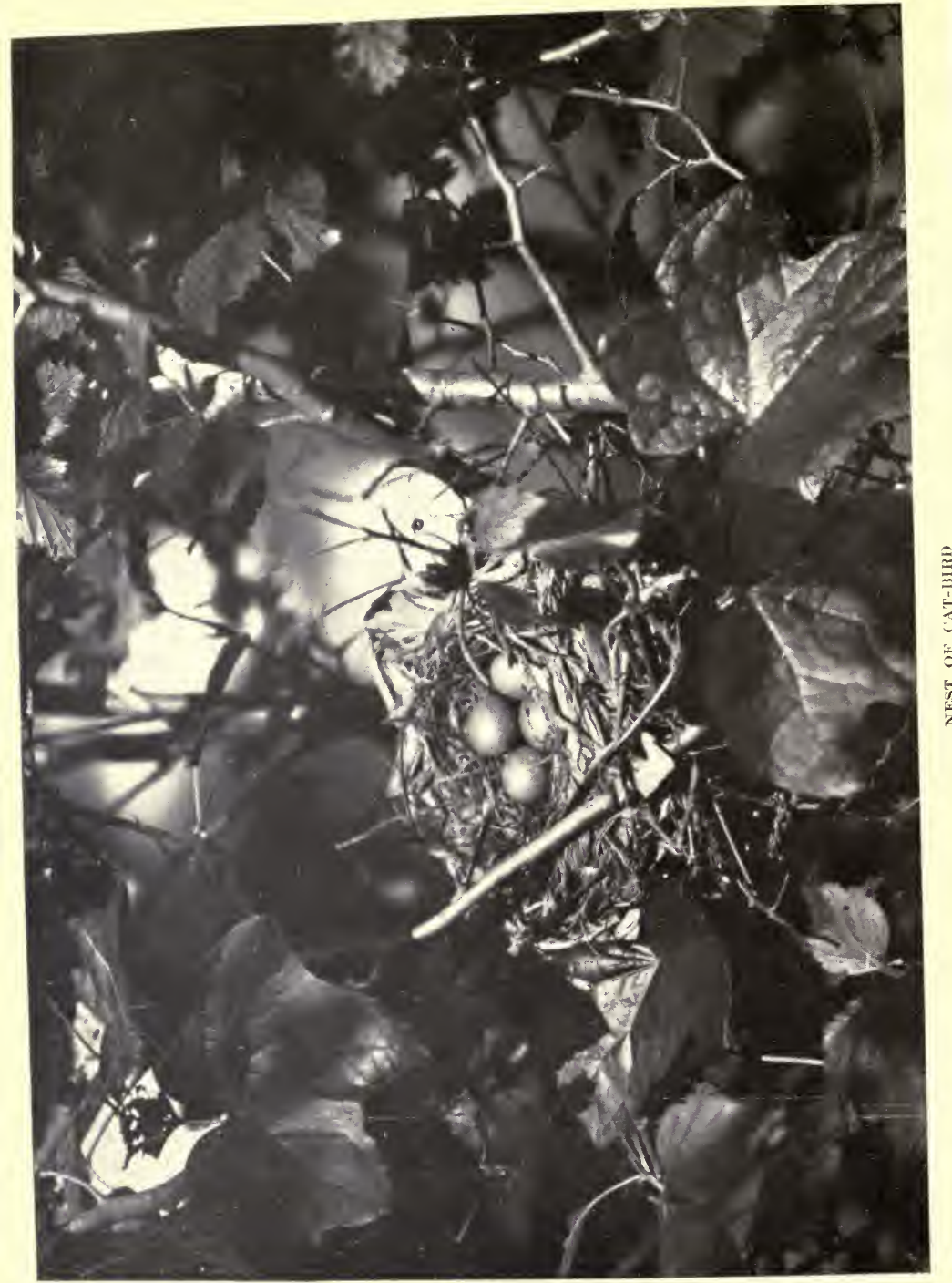




\title{
CHAPTER XIV
}

The Cat-bird: Galeoscoptes Caroliniensis

\author{
IN THICKETS
}

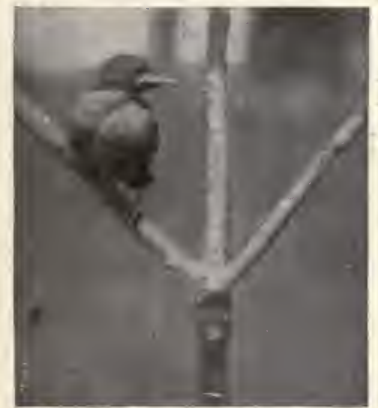

YOUNG CAT-BIRD

"Guess what I have for you," commanded Bob.

“Nest of a Ha-ha bird," I ventured.

"Ha, ha! Nests of forty other. birds," he retorted.

I stood staring. Several days before I had confided to Bob that I was in trouble. - I had accepted a position on the staff of an outing magazine, contracting to furnish, during the ensuing year, at least nine natural-history articles, each illustrated with from four to ten studies of birds. At the time of making that contract I had only four pictures suitable for use. So I appealed to him to watch closer than usual as he passed from well to well beside the river; and to mark every nest he saw for me. This was the answer-the answer big as the great heart of Bob. My spirits bounded. Forty nests!. Why, from them material could be secured to last me three years.

"Bob! What kinds?" I cried.

"Oh, Robins, Cat-birds, Cuckoos, Larks, Doves, Redbirds, Jays, Red-winged Blackbirds, and a lot of little fine stuff of which I don't know the names." 


\section{FRIENDS IN FEATHERS}

"A lot of little fine stuff !" That meant Warblers, Finches, Vireos and sparrows.

"And the prettiest thing in the lot," said Bob, "the one you must photograph first, is the nest of a common old Cat-bird. I never saw anything prettier in the nest line."

That same day I began a series of drives to Bob's lease that continued every fair day throughout the season. The trip was a delight. The way lay across the levee east of the village, where every attraction of wood life was to be found growing in a tangle, while a babel of bird-song swelled early and late, led always by the Bell Bird I had pictured a few days before, which I now claimed as my especial property. After crossing the bridge, the green line of the river, decorated with the white bloom of hawthorn and wild plum, lay always in sight. At Bob's lease a sudden curve brought the water to the road, then swept it away again learing a pressing invitation to all and sundry to follow to learn from the Wabash itself why people wrote poems and sang songs about it.

The lease lay on both sides of the road. On the right as you approached was the Aspy farm, where the Bobolink strutted the rod-line; adjoining it on the same side was Stanley's where the Shrikes homed in the oak, Kingbirds in the orchard and Larks in the meadow.

On the left lay a strip of high, grassy, wooded pasture, cut into curves by the river, on the near bank of which was the power house. Below the house and oil-tanks was a grassy old orchard running down to the water. Across the river was a deep wood, with large pools frequented by Bittern and Heron; tangles of underbrush, and forest trees of the height and size selected by Hawks and Crows. Where could be found another such Paradise for birds?

Bob did have forty nests located, while he had not worked very long to do it. That day was spent in taking an inventory 



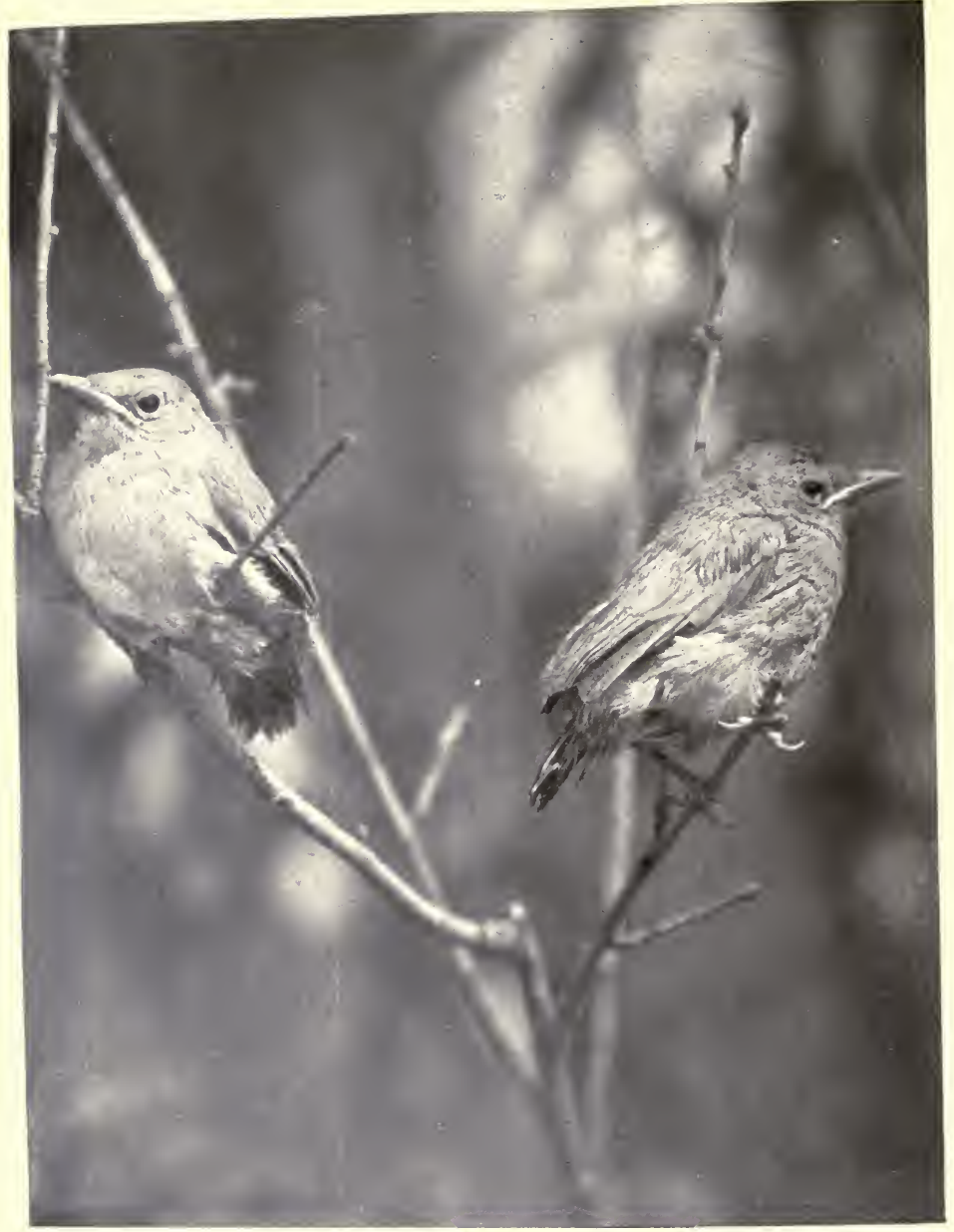

YOUNG CAT-BIRDS

"Cat-bird nestlings are so gentle as to seem almost Dove-like" 


\section{THE CAT-BIRD}

of them, going into ecstasies over their beauty, trying to decide, by the condition of the nest and the bushes around, on which to work first, until we reached the nest of the Cat-bird-there I stopped, charmed with its beauty. Without a word Bob leaped the old snake fence, crossing the orchard to bring the camera.

The nest was in a red haw thicket in a corner of the fence separating the orchard from the meadow. It was low enough to take from a tripod, there was no obstruction to prevent my setting it exactly where it should be placed, while the light was fine. Photographic conditions could scarcely have been bettered in field work. It was imperative to record the nest at once because browsing cattle, angered by flies, might run into the bushes, destroying it any hour.

The fence was a lichen-covered, linty, picturesque old affair; the bushes were young and newly leaved in rare shades of golden green; beautiful vines clambered everywhere, while moss, ferns and wild flowers grew beneath. The nest was built of fine twigs such as were numerous underfoot in the fence corners; but somewhere in the fields the Cat-birds had found a finely shredded corn-husk, or one so old that they could shred it themselves, for the nest was lined with this material, bleached almost white. There was some dry grass also, while the eggs were that exquisite deep blue-green of this species. That was the picture. No wonder Bob hurried for the camera! Of all the forty nests into which we had gazed with reverent wonder that morning, not pendent purse of Oriole, cobweb-decorated cup of Vireo, living green arch of Lark, or flat bowl of Quail had been so beautiful as this.

Of course it could not wait, so I made two exposures to be sure. Then overtures to the Cat-birds began by sprinkling cracker crumbs, of which they are very fond, on the top rail of the fence. The mother bird proved why she was named by keeping up a 


\section{FRIENDS IN FEATHERS}

feline concert in the thicket. "Me-aw, me-aw, me-aw!" "Meow, me-ow, me-ow! 'Arry, 'arry," then insistently: "II ar-ry! II ar-ry!"”

Making friends with her was a task. The Rubicon was a circle nearly three yards from her in any direction; when you rrossed it, no matter with what adroitness you made your approach, she vanished. I never secured a study of her brooding. It was impossible to take it without separating the bushes, while not even after her eggs had (quickened could I touch her fencecorner without her taking flight.

While making these efforts my appreciation of Cat-bird music doubled, but all I ever had of Cat-bird character was lost; so that in these days, the memory of those hours of watching. filled with the exquisite morning and evening song of the Cat-bird father as he perched in a topmost bough of the old apple-tree, is what keeps me from destroying every nest I find.

Ile liked a big Rambo closest his location; there, from a high twig the mimic copied the notes of every bird of the lease. He could do the Robin's rain-song beautifully. He reproduced the Bobolink of the rod-line, across the road, until he deceived me if he opened his matins with that strain. He piped the lay of the Song sparrow, and warbled like the Warblers. He could not whistle, but he could catch the "Co "cheer, co'cheer!" notes of the (ardinals across the river. In fact, traces could be detected of the notes of every hird of the orchard, meadow and forest excepting the Lark and the Quail.

He mixed them all up, worked them over, then poured them out in a continuous and ever-changing stream of melody so fast one had to do mental gymnasties to place each note. Then at times he became inspired with his own performance, his beady eyes threw gleams of light, his throat swelled its fullest while he rocked the twig he perched on improvising a melody of his 


\section{THE CAT-BIRD}

own that was a reminder of all fine wood music yet a repetition of none. Because of this I forgave him much.

There was much to forgive; for among Bob's forty nests there were Blackbirds, Song Sparrows and Doves on that same stretch of fence, before it ended at the river. There were Kingbirds, Robins, Vireos, Bluebirds and Orioles in the orchard; beside the river, Cardinals, Cuckoos, Warblers, Indigo Finches, Sandpipers, Grebe and Shitepoke; while in the meadow were the Bobolink and Lark, Quail and Ground Robin. Into the home affairs of each bird of them at some point in my work came that Cat-bird with his sharp little beak and sharper black eyes. Much that I formerly had laid to the credit of my ancient enemy the Crow, in reality proved to be the work of the Cat-bird.

He stole eggs from Vireo and Warbler when only two and three in a nest proved them fresh. It was so easy, while a little mother the size of a Goldfinch was bathing or exercising, to slip to her nest, pick out a tiny, thin-shelled egg, crush it, and suck up the contents. Also he was responsible for the disappearance of many newly hatched Warblers and other birds of their size, because one day, directly before my lens, he darted to the nest of a Summer Yellow Bird, snatched and swallowed a baby as if it were a juicy grub.

That day I determined to ask Bob to shoot him. The following morning, while making studies of a pair of his own nestlings, he paid me the tribute of singing to me, as I worked; his mixed chorus of orchard, meadow and forest almost broke my heart by the most beautiful improvisations I yet had heard from him, and ended my captivation quite by continuing his song while two of his young perched on my hand, instead of coming down and frightening them into a panic with his cat-calls as I feared he would.

So now I am traitor to other dainty little folk I should protect, for while beyond all doubt he is responsible for much dam- 


\section{FRIENIDS IN FEATHERS}

age, every time the opportunity comes to tell on him and urge his partial extermination, at least, I find myself hiding his sins, excusing his shortcomings, all because of his exquisite song.

There is small enough cause to love him. He follows me through the woods for a mile arousing suspicion and fear in the hearts of more trusting birds by his questionings. Many weary waits with a set camera have been just at the point of fruition when a Cat-bird came mewling around, made my subject flighty by his intrusion, so spoiling my picture.

He is more pervasive and inquisitive than the Blue Jay. He differs from the Jay. Convince a Jay that you are a part of woodland life, that you are not shooting or making a disturbance, then he will go away and leave you alone. But a Catbird is always questioning, never seeming to find a satisfactory answer. He fails to become accustomed to your presence around other nests, which is pure perversity, for he will accept you near his own when he feels assured that you are doing no damage. If hunger-pangs or family cares did not strongly call him, he would follow me all day, watching, questioning and interfering with what was happening to other birds.

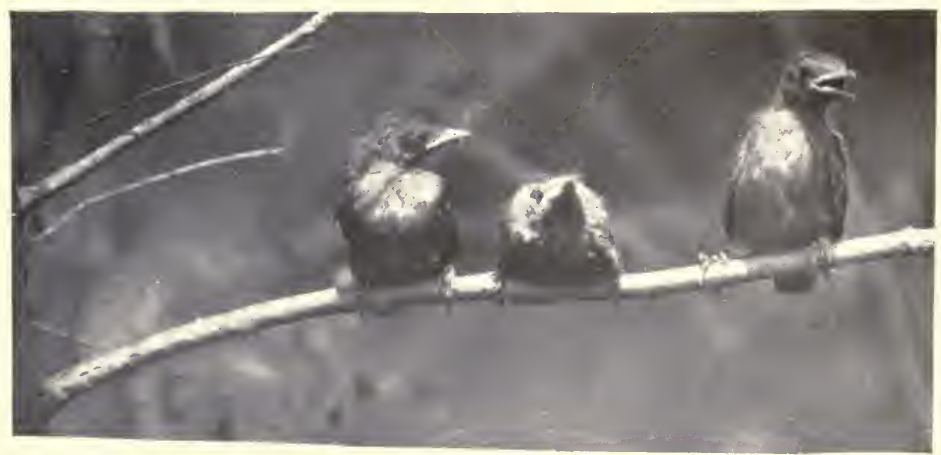

YOUNG CAT-BIRUS 



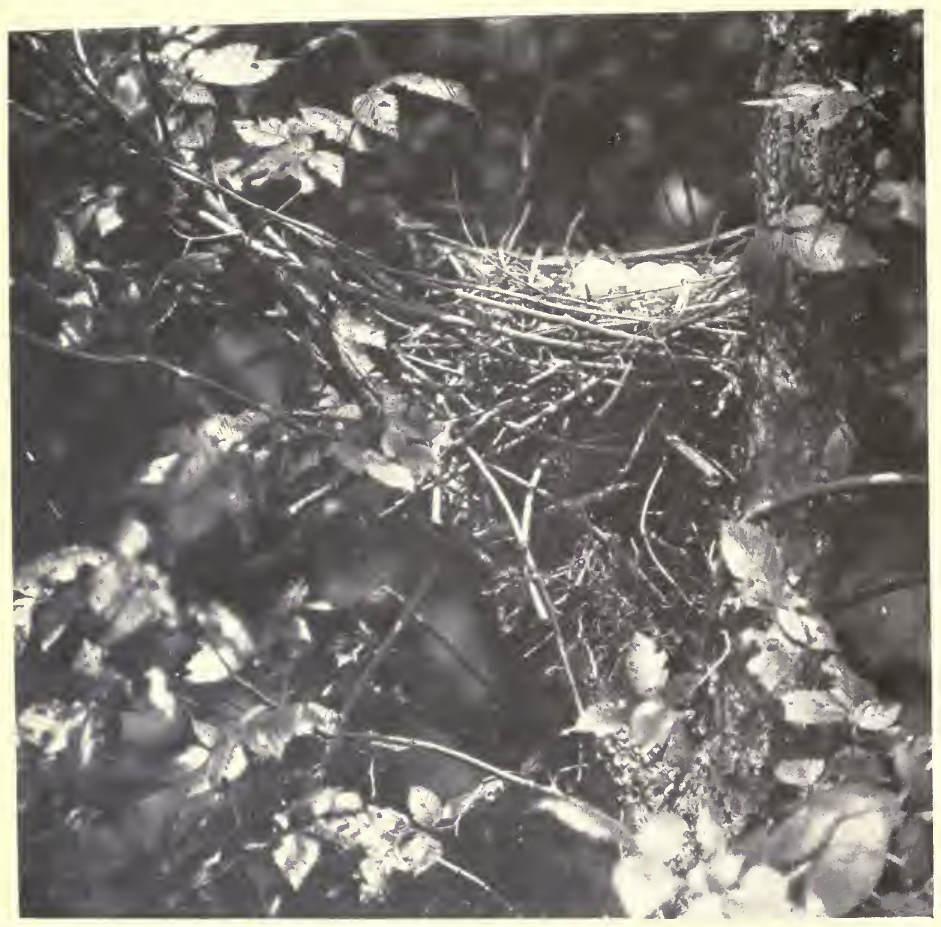

CUCKOO NEST ON SHITEPOKE FOUNDATION 


\section{CHAPTER XV}

\section{The Yellow-Billed Cuckoo: Coccyzus Americánus}

IN SMALL THICKLY LEAVED TREES

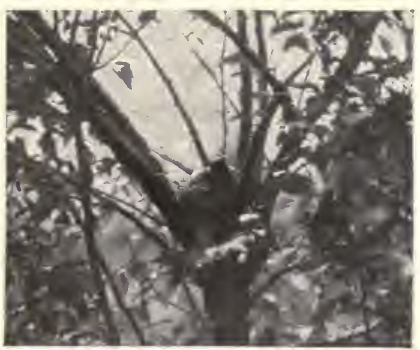

BROODING CUCKOO

I LOVE the Cuckoo. In this taste there is much good company, for I could quote, to the length of a chapter, poems and songs by lovers of the bird. Traditions concerning it are almost as old and as interwoven in fable and legend as those of the Kingfisher. It is an individual bird, while its characteristics are sharply outlined. It is a bird that has been slandered by writers learned in the lore of books, but lacking in knowledge of the woods and the actual habits of birds.

There are charges against it of depositing its eggs in other birds' nests, as do its European relatives. Surely in the length of my life, I have looked into as many birds' nests as any other one person, yet I never saw a Cuckoo egg that had been deposited with other species. It is charged with destroying the nests and young of other birds; I never have seen a suspicion of this characteristic in it, and I have yet to meet a real natural-history worker, of the woods, who has. It is accused, by writers who should know better, of having a filthy, repulsive nest and badly soiled surroundings. This would be to advertise its location widely, while one of the most prominent characteristics of the bird is its power of concealment, its secretive habits. 


\section{FRIENDS IN FEATHERS}

Two of my most beautiful Cuckoo nests were on the Hale farm, one of them being pointed out to me by Mr. Will Hale the same day he led me to the Kingfisher's location. 'This nest was in the crotch of a scrub elm, close twelve feet from the ground, in a thicket on the bank of the small lake opposite the Kingfishers. I ean not prove what bird originally built that nest, but I do know the Cuckoos never did. The structure began in the sharp parting of the branches, being one and a half feet in height. Some of the sticks used in its construction toward the top were the thickness of a lead pencil and three feet long. My guess would be Shitepokes. Mr. Hale told me the nest had been there sereral years. The Cuckoos spread a handful of their fine twig nest material in the bottom, pulled a few dry pussy-tails from the willows and they were ready for nesting. I photographed the nest when it had three big pale greenish-blue lusterless eggs in it, so it made a most interesting picture.

Possibly from making use of abandoned rests, as in this case, the Cuckoo has some of its bad reputation. On Mr. Black's lease, in the past five years, I have seen perhaps a dozen different Cuckoo nests, photographing many of them. In a little red haw-bush, not three feet from the ground, Mr. Black found the lowest of these nests and the most characteristic. It was a mere handful of twigs, loosely laid flat on seemingly the slightest foundation, and dropped into the numerous interstices were maple blossoms for lining.

In all about half a dozen of the most beautiful nests were recorded because they contained an unusual number of eggs or for a reason which seemed to me good. I worked for days around half a dozen more containing young birds up to the day of departure. In all that time I never saw a hint of droppings on or around the nests, and on all of the dozen negatives, which include liberal portions of surroundings, not a soiled leaf can be seen. 


\section{THE YELLOW-BILLED CUCKOO}

I stated in the introduction that in instances where the young were similar to their elders and I had secured studies of them when half grown, they would be used in preference to the grown birds, because as a rule ten people out of every dozen who care for birds prefer these unusual pictures of the young. Cuckoos are in this list, but they should be taken out. Here I do not use the pictures of the young for that reason. I should be most proud to publish a reproduction of the grown Cuckoo, as I never have seen one and should regard the picture an achievement. I have tried and tried, many times, but so far I always have failed. The habits of the bird make failure in his case almost certain.

In the first place, their location makes a snap shot impossible, while in the second their nature makes a time exposure equally so. They always choose a secluded location where experience teaches them that probably they will be solitary. They select the thickest place they can find, where leaves grow in masses, for their nest. They are not so unfriendly. One can approach very close, but in the dense shade and surrounded by leaves as they are, a picture is not possible unless time could be given, which is not feasible, for the instant one pauses, the bird is gone with exactly the same motion with which a big black watersnake glides from bush to bush in dense underbrush.

Jacob Studer says the Cuckoo is a "slipper;" the term fits him perfectly. He is indeed a slipper. The word seems coined to describe this subject. The Brown Thrush can not equal him in the graceful art of vanishing in deep shrubbery. So I never have secured his likeness.

The Cuckoo always is associated in my mind with deep, thickly leaved, cool places, where moss and wild flowers cover the damp earth, where silence reigns and solitude is unbroken. It is from such places that the weather prophet booms his never-failing 


\section{FRIENDS IN FEATHERS}

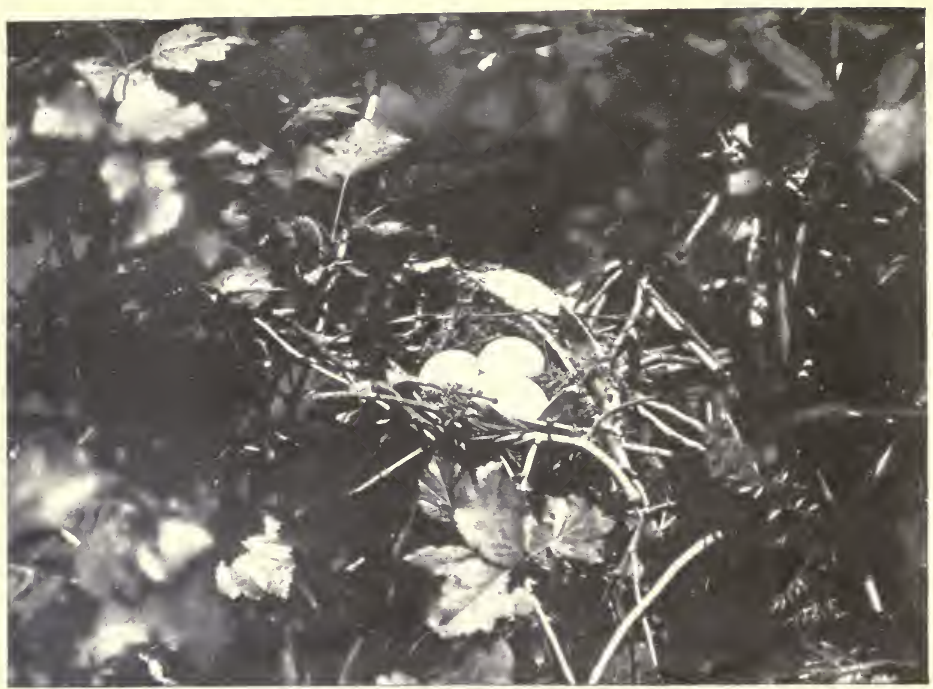

TYPICAL CUCKOO NEST

"I mere handful of twigs, loosely laid flat on seemingly the slightest foundation, with maple blossoms for lining",

predictions of rain, which for this reason sound so startling. I think of him as very near to the heart of nature, slipping gracefully through his green haunts, coloured like the young tree- and hush-stems, and the half-faded and withered leaves around him. Never a feather out of place, and what delicate shades of colour make up his suit!

'There is a hint of leares in the greenish satiny reflections on his gray back. There is a touch of cinnamon brown on his wings. His tail is a work of art, the two gray middle feathers being twice the length of the outer ones, which are black, tipped with white, 


\section{THE YELLOW-BILLED CUCKOO}

and taper gradually to the pointed middle. Underneath he is snowy white, with bluish silver reflections on his throat. His bill is long and graceful, curved at the tip and broad at the base, the upper mandible grayish brown and the lower yellow. His hazel eyes are quick and beady-bright, he drops his yellow lids in a roguish way, while his feet, slaty blue with two toes front and two back, are as trim, clean and graceful as the remainder of him. At the knee he has the long Hawk-like feathers of his species. His head and body are slender, being beautifully proportioned. When on rare occasions he comes to the light so the sun strikes his greenish back, reddish wings and the delicate pale blue of his throat, as an example of exquisite colouring, I should not know where to turn to choose a bird that can surpass him.

This is a treat one rarely has, for he keeps in the underbrush. Where that fails him, he interrupts his flight at every small tree. On the ground he seems at a loss to use his feet with ease and trails his wings and erects his tail in a comical manner. He is always eating; a spider here, a larva there, and caterpillars all the time. He is provided with a flexible gizzard, lined with hair, which makes possible the eating of this worm which is rapidly destroying our fruit; so a Cuckoo is worth many times his weight in gold in any orchard.

Of all the young birds I ever have pictured, a Cuckoo is my favourite. I can not tell how exquisite are the colouring of the fine silken throat-feathers or the shades of the back. The big hazel eyes, the graceful beak, the slender feet,- the whole baby immaculate and trusting, tender and gentle of disposition to surpass any birds I know. They climb out of a nest on your fingers and all over you, coo and peer as if fear or distrust never existed. All you have to do to make a study of them any way you can think of is to hold out your hand-they will climb onand place them on a branch face or back to the camera. They 


\section{FRIENDS IN FEATIERS}

will sit in any position, and look perfect pictures of trust and confidence. I always carry food with me, so if I am working long with young birds, and they grow hungry, as they do with amazing rapidity, with a little paddle I feed them a few bites. I give baby Cuckoos the yolk of hard-boiled egg. When feeding them I moisten the egg with saliva. They are eager for it and will pose indefinitely if they have a bite once in a while.

With Cuckoos the whole process of family affairs is individual. They can confide four and five nestlings to a piece of architecture more rickety than a Dove's nest. The mother is erratic about her laying, but begins incubation with the first egg. As a result the brood drags along, and before the last of the first clutch is out of the nest, eggs for the second are deposited. In any event, the babies leave, one a day. The difference in their size and feathering is surprising. I have seen nests containing a brood with one ready to fly, one half-feathered, one covered with sheathed feathers, and a freshly laid egg.

Until the day of quitting the nest Cuckoo babies are the fumniest little fellows imaginable. Their bodies are covered with a tough leathery black skin, while each coming feather is incased in a black, pointed shield. This gives them the appearance of porcupines. If you touch the nest at that stage they draw back, erect those spines and cry - a reedy whine of a cry that is distressing. They know they have no business being touched in that condition. When the hour to leave the nest begins to approach, in a short time these shields burst and the small leathery black bird becomes a thing of delicately shaded silken attire and assured tone of voice.

Once this sudden emerging of the Cuckoo baby appealed to me as so comical that I made a series from a pair of nestlings to illustrate it. 'The birds hatched in a thorn thicket on the river-bank on Mr. Black's lease. 'Two had left the nest and we 



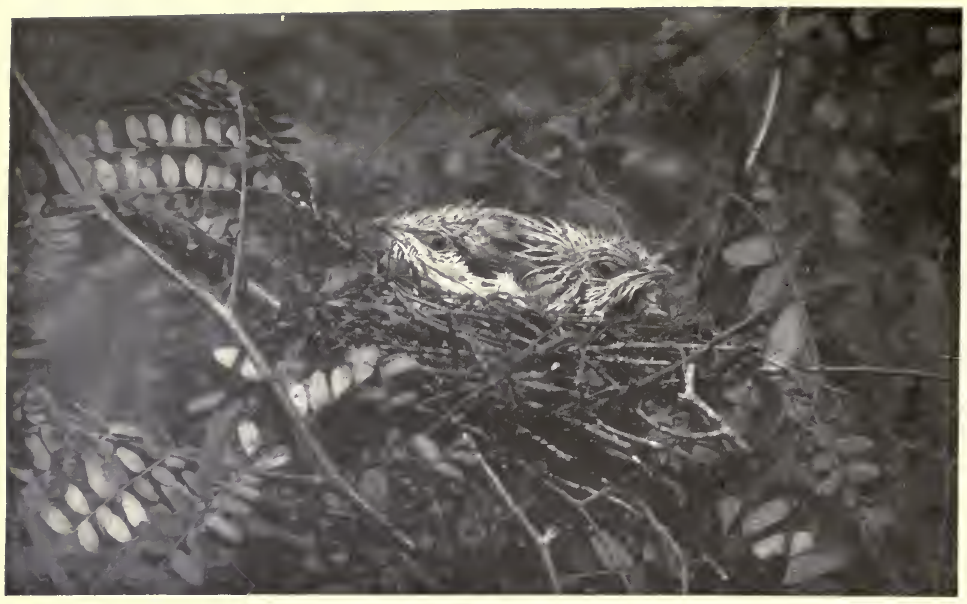

IN THE NEST AT NINE A.M., AUGUST FIRST, 1901

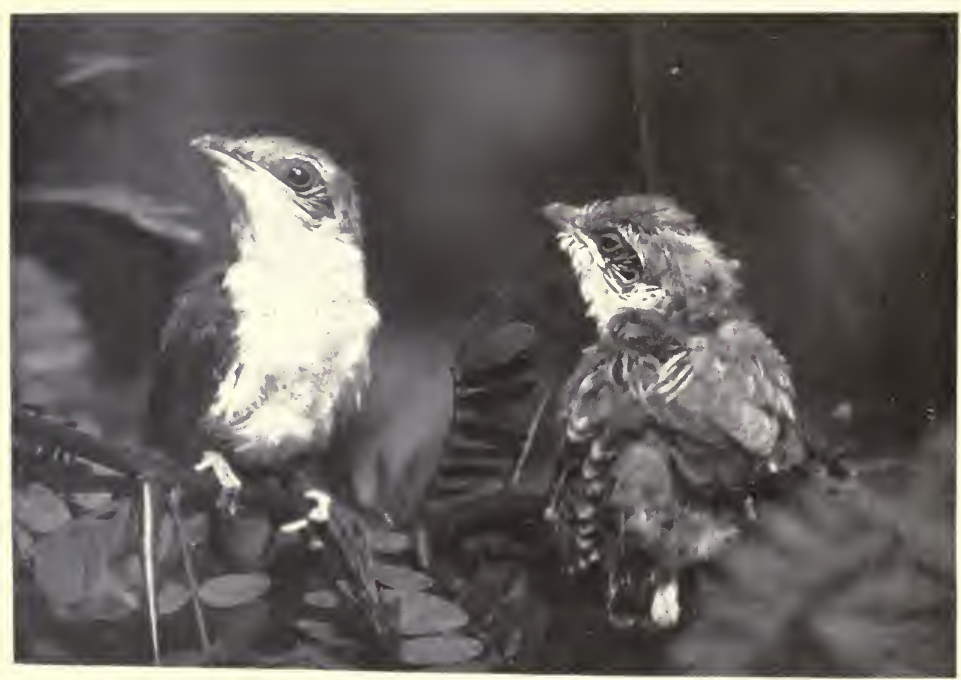

ON LIMB BESIDE NEST AT THREE P.M., AUGUST FIRST, 1901 


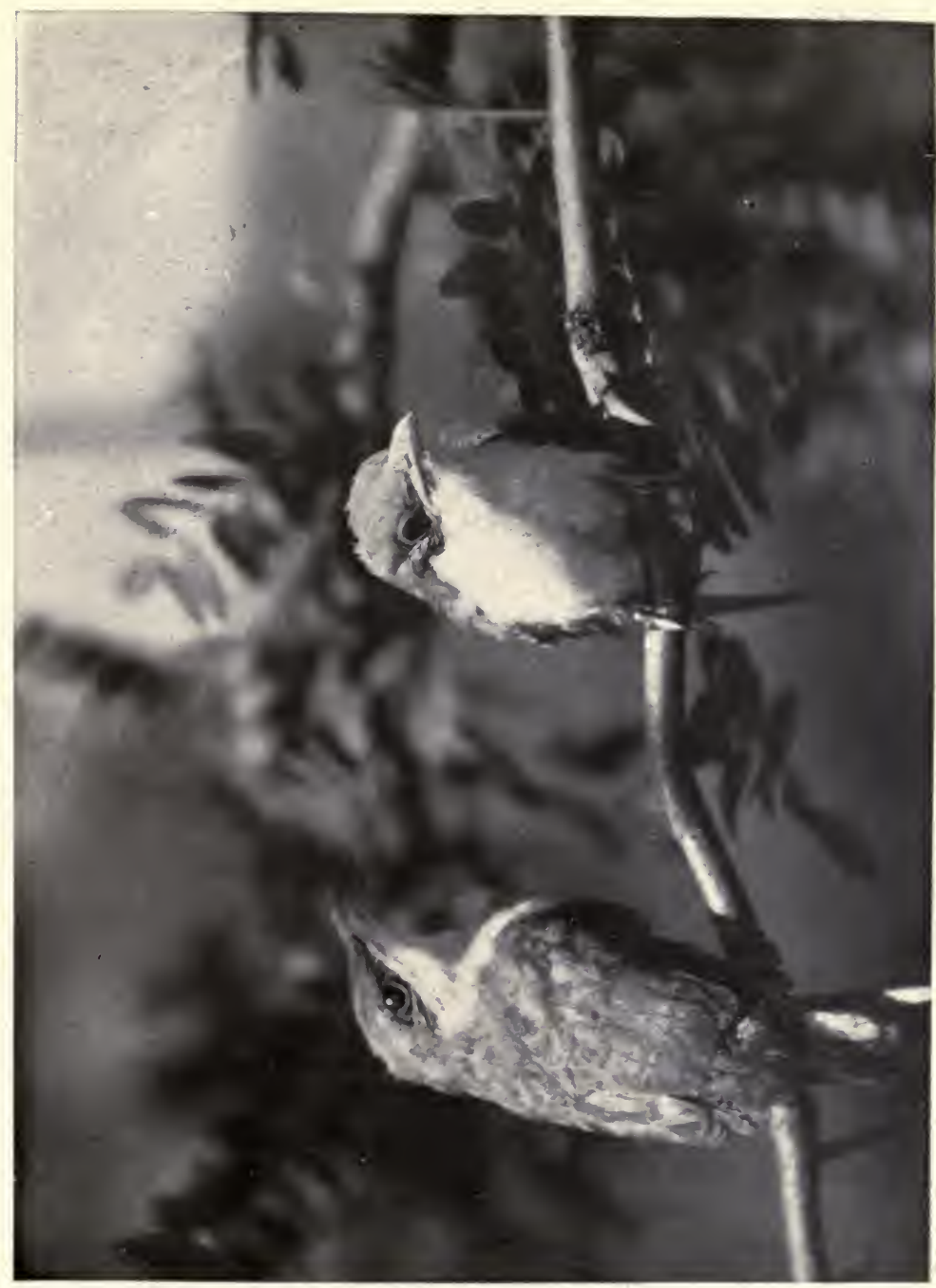

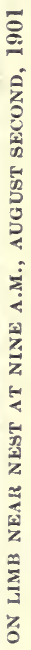





\section{THE YFLLOW-BILLED CUCKOO}

knew the others would go the following day. I arrived at the lease at nine o'clock on the morning of the first of August, 1901, and made my first study of the series reproducing the evolution of the Cuckoo. Not a shield had opened on the baby, but on the elder a few were breaking across the back of the head and over the breast.

At three o'clock that afternoon only two or three shields around each eye were left on the elder, while the baby was almost feathered. Both of them were clambering around on the edge of the nest, but settled down into it that night and were sheltered by the mother. At nine o'clock on the morning of the second not a shield was to be seen on the elder, and only a few small ones around the eyes of the baby.

At this point in their careers they climbed all over me and the thorn-tree, ate the egg, and posed until I was out of plates. They were the softest of plumage and the sweetest of disposition of any young birds I ever had handled. They had no sense of fear and made no effort to fly. They did not even stand up, lift their wings and try them, as do so many young birds. Bob said: "Well, aren't they 'most too good to be true?" And they were. I can not guarantee that they would be as good for everyone, but if any natural-history devotee wishes to try, here is the receipt.

Use plain common sense. Approach the nest slowly, and when the young begin to cry, imitate them so that they will think you a kindred thing. Always carry suitable food, and the instant any baby opens his mouth, have ready your little paddle well loaded with egg, quite moist, and drop the food carefully into him. Then the others will follow suit.

Feed them several times, with half an hour's wait between, to get them accustomed to you. Take them first in the nest, then if you want to scatter them a little, or to take a pair, hold the food out of their reach and coax them to it. If they will not 


\section{FRIENDS IN FEATHERS}

come, leave them alone until the following day. When they are ready to desert the nest, they will follow egg, properly prepared. If you want to set them in some especial place, never pick them up and pull them by main force. If they are in a nest they will grip with their feet and wreck it. If they are on a limb rou will almost pull the tender little things in two. Slip your fingers into the nest and gently work them under their feet. The toes will clasp firmly around the fingers, then by moving slowly, aroiding noise and being gentle with them you can do what rou choose.

I have been told by nature workers and read in many books that it was impossible to take a young bird from the nest, put it back, and have it remain. I should not advise anyone lacking bird sense and years of experience to try it; but I have done it all my life, and never once have I failed to put back a young bird taken from a nest, and it always remained. This may be due to the fact that I never try to lift a baby from a nest unless it knows me and will accept food from me, so I am sure I can manage it. I should not dream of walking up to a nest of young birds and attempting to touch them, without preliminary acquaintance. Of course they would jump, even if they were not ready to go for days!

If anyone having a prejudice against the Cuckoo will enter its dim, leafy haunts, make friends with it until he learns at first hand its habits and nature, cultivate the young to the handling point, and come away without being a Cuckoo enthusiast, he is a very queer person.

In June of 1906, after this book was with its publishers, Mr. Black said to me: "There is a Cuckoo nest you should see on the Aspr place."

"I have more Cuckoo nests now than I ever can use," I answered.

"But this is different," insisted Bob. 


\section{THE YELLOW-BILLED CUCKOO}

"Different in what way?" I questioned.

"Two," replied Bob. "This pair has fixed over that Robinnest that was in the thicket before the Cabin last year. It is so close the ground you can take it from a tripod, and one egg is fully one-fourth larger than any of the others. Doesn't that tempt you?"

"Yes," I said. "It tempts me to try "just one time more to make a study of a brooding Cuckoo. I never before had a nest where I could work on it from the ground. That is half the battle. Then the plum-tree the Robin-nest was in is on the edge of the thicket near the Cabin. The light is right in the morning. You have been going within a few yards of it for water three and four times a day so the birds must have become accustomed to you while they were repairing the nest and depositing the eggs. If you want to do something for the good of the cause, educate Mother Cuckoo until you can go where I would want to set a camera without once causing her to desert."

"I'll do it!" said Bob.

"You'll do it!" I jeered. "Yes, it will be so easy!"

I had as nearly given up photographing a grown Cuckoo as I ever give up any bird of my territory. I was in the midst of the busiest and the most aggravating season of field work I ever had experienced on account of constant June rains, and I confess I forgot the Cuckoo and did not even go to see her. A few days later Bob came to me.

"I can go within fifteen feet of that Cuckoo and make as many motions as you would to take a picture," he said, "and she sticks!"

It would have been impolite to tell so old and trusted a friend to my work that I could not believe him, but I scarcely could. Taking a tripod I drove east to the Aspy farm at once. It was about seven o'clock in the evening. 


\section{FRIENDS IN FEATHERS}

The old cabin around which a brood of rosy, happy children once romped now stood doorless, windowless, floorless and deserted, across the road from the orchard where so many highlyprized studies had been obtained, and beside the open, sunny clover field of the Bobolink. What once had been a front yard that was a gentle little woman's pride and care now answered no description save thicket. A big cottonwood in one eorner had thrown up a thousand rank sprouts; so had cherry, peach and plum trees. Cabbage and bride roses had spread to masses; honeysuckle, creeper and grape-vine clambered everywhere, while striped grass and day lilies filled the interstices.

The path Bob travelled to water his horse was worn smooth, and following it around the bushes to the well I could see a new trail leading through knee-deep grass between the thicket and the Cabin. A few steps brought me in sight of the nest. The location was even lower than I remembered it, and while the plum-tree really belonged to the thicket it stood on the very edge adjoining the clover field and the (abin. The clipping of three little twigs would be all that was necessary to secure the best light there could be on the beautiful brooding bird.

She was of the black-bill variety. The instant she saw me I paused and waited a long time. Then slowly, and with greater caution than I ever before used, I advanced until I stood at the place where Bob's trail stopped. There the tripod was cautiously set up. 'Then slipping off' a long gray cravenette, rolling it up and placing it as I would a camera I went through every motion necessary to make a study of her. She watched me steadily, but never moved. IIad I brought a camera, had light, and the intervening twigs been removed, she could have been photographed then. A little clipping was imperative, so thinking it over I decided that she would return to her nest in the evening sooner than in the morning, when she would have left once to bathe and 


\section{THE YELLOW-BILLED CUCKOO}

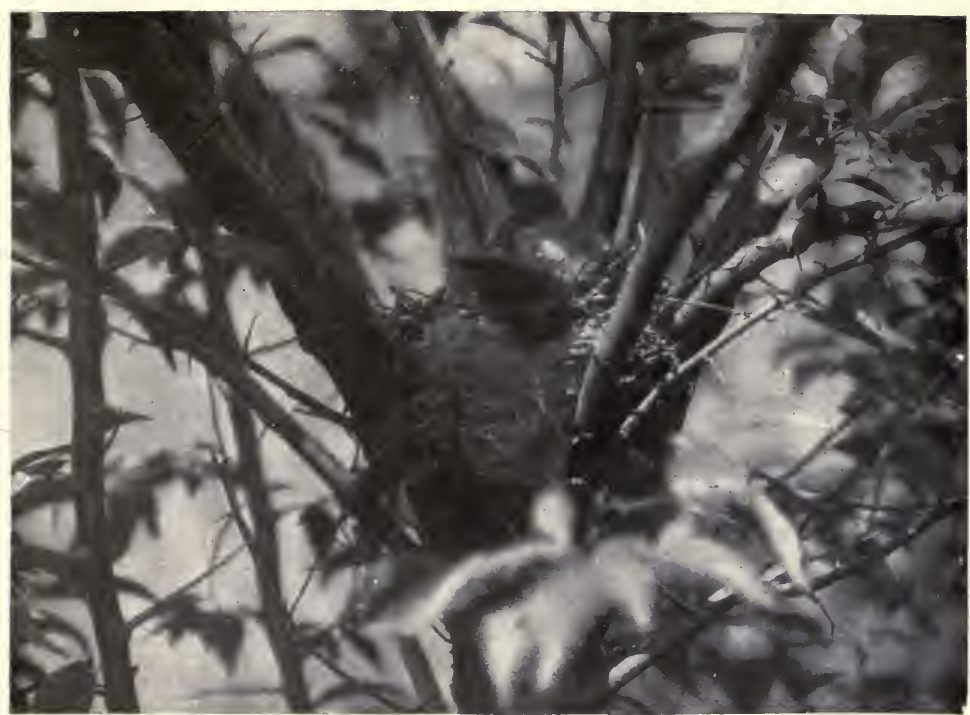

PROVING THAT MOTHER CUCKOO WOULD BROOD WHILE I WORKED BEHIND HER

drink. I went back to the carriage, brought my clippers and approached the nest again, as cautiously as before. She left when I was close ten feet from her. With all possible speed, cutting not a twig that was not necessary, I cleared the foreground and hurried away.

That night the nervous strain was so intense I could not sleep. The following morning I was at the Cabin as early as there was light and tried to approach the nest with tripod and camera. At fifteen feet Mother Cuckoo simply vanished. There I stood sick with disappointment. The previous evening had made me too sure. There was nothing left to do but vanish myself. Thinking it over I realized in bitterness that it was a mistake to go early or 


\section{FRIENDS IN FEATHERS}

try to approach her so soon after she had been from the nest for her moming exercise. Late that afternoon I returned. The light was directly in the face of the lens in case I had a chance to set up a camera, but I wanted to accustom her to the process.

It seemed to me I used an hour to go from the well to a spot as close the nest as possible. I never wanted to make a study of a bird more, and so worked in greater trepidation, and with caution that I never before employed with any subject. That shỵ, slipping, deep wood thing-if I only could reproduce her! She allowed me to set up the camera, and focus on her, so I shaded the lens, made a time exposure and left without causing her to desert. That night I made up lost sleep, for I felt that "I had the hang of it now and could do it again."

The following morning, instead of going early, I waited until eleven o'clock, which was as late as I dared risk the light; then with the same deliberation and caution I approached her again and made three exposures, each time slipping the camera slightly closer. She sat, as brooding tree birds always do, on the point of her breast. Her tail was toward the lens and her head at the farthest side of the nest. That was not a position I would have chosen, but it was a very good omen that she would stay when she had her back toward me. IIad she brooded facing me, she would have been compelled to make an impulse in my direction in order to reach the deep shrubbery, which she would not have liked to do.

The day after I went an hour earlier, moved up to ten feet, and exposed two more plates in the same attitude. The following morning she was in a beautiful position, sidewise toward the lens, showing her outline from beak to tip in one elegant sweep, her black bill, her red-rimmed eye, and the exquisite shadings of her silvery throat and the bronze of her back and wings. She was all of twelve inches in length. I set my teeth hard to keep 


\section{THE YELLOW-BILLED CUCKOO}

my heart from jumping from my mouth while I exposed a twentysix plate for the fiftieth of a second. Then I took it over at a twenty-fifth, for fear the first exposure might have been short. And there she sat!

At my feet lay a plate-holder that fits inside my camera. There were more time-plates in it. Should I? With all deliberation I turned the camera front toward me, inserted an enlarging lens and turned it back. Then almost breathlessly, if anyone wants excitement! I began walking that tripod toward her. First I would reach through under the camera, and tilting it back a little, set the front leg forward six inches, then each of the side ones in turn. At last I was so close I had to use the extension front almost full-length to get her in focus, but she never flinched as the shining big glass eye came sliding toward her. If she were frightened she gave none of the usual signs, for she crowded no lower in the nest, nor did she plaster her feathers any tighter to her body. She brooded lightly, easily and appeared exactly as she did before the camera ever was placed near her.

When the first exposure was made the sun was shining brightly. One little spot of light struck the top of her head and another her shoulder. I inserted a second plate, lengthened the exposure and waited as motionless as possible for over fifteen minutes, until a cloud I could see coming up obscured the sun enough to wipe out those spots of light. Then came the exposure I had coveted for years, the picture used as the frontispiece to this book; but my fingers are crowding on the keys of my typewriter in my haste to acknowledge that I owe it entirely, as I owe so many of my best studies, to the kindness of Bob.

I knew of no way to better that latest exposure, so I inserted a fresh plate, stepped up beside the camera and said to the Cuckoo: "I want a study of your nest showing your big egg now. Won't you leave, girlie?" She made no movement to go. One more 


\section{FRIENDS IN FEATHERS}

step brought my face level with her. I lifted my hand and gently stroked her wing. Then she stood in the nest and looked down to see what was there, exactly as a brooding hen. I gave her the slightest push so she hopped to the edge of the nest. That broke the spell of the brooding fever which had bound her and she was lost in the thicket. I would have given much to recall her, for the first nestling was struggling through the shell. That explained her conduct. I had approached her at precisely the psychological moment, when, knowing she had not been hamed previously, she would stay. There was no use for a study of a nest with so small a bird in it so I removed my camera without waiting to close it or take it down. Before driving away I took a last peep. She had returned to the nest and was settling to brood again.

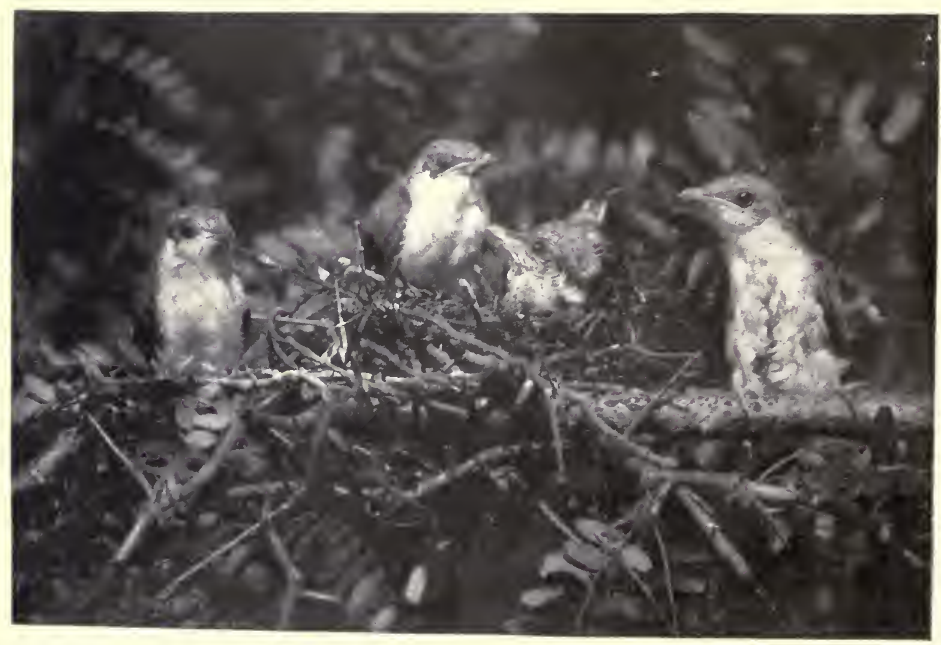

READY FOR THE MERCIES OF A WORLD NONE TOO TENDER 



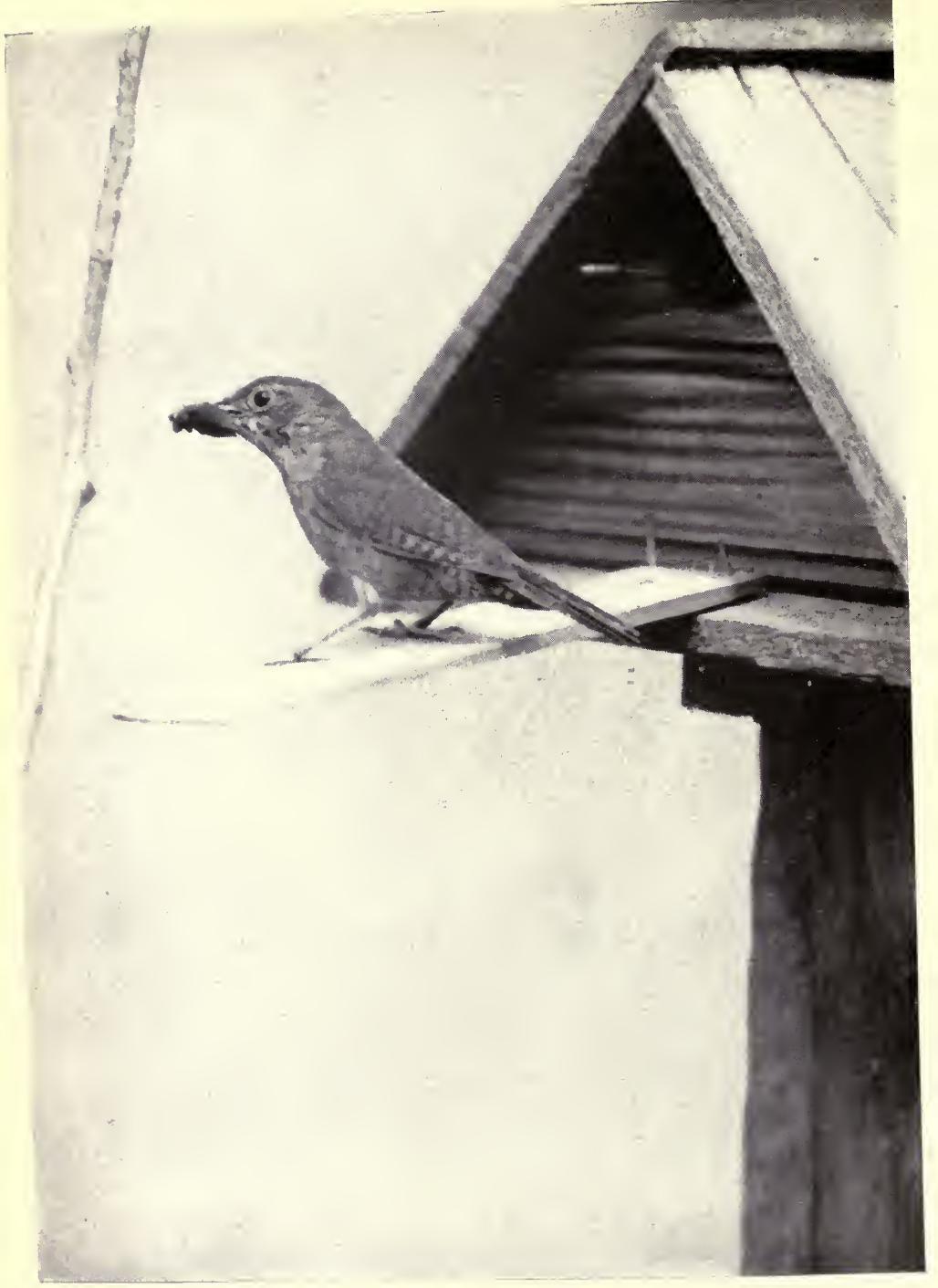

MALE WREN EMPTYING CLOACA OF YOUNG 


\section{CHAPTER XVI}

House Wren: Troglodytes Aëdon

IN BIRD-HOUSES

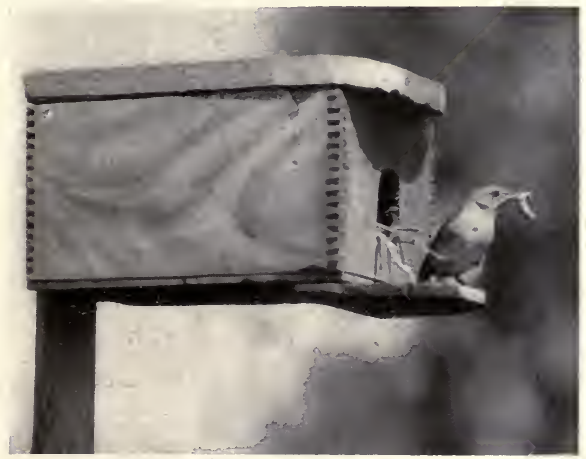

MOTHER WREN CARRYING WORM TO YOUNG

From their continuous strongly exhibited preference for homes close or beneath the shelter of men, these birds, as no others, have become the birds of the home. I cannot recollect one summer of my childhood when the front door of a Wren's house failed to be a knot-hole in the weather boarding over our kitchen door, while the last perching place on their going to, and the first of their coming from, their entrance was an ornamental acorn on the top of the pump. Each nesting season my mother sternly threatened should be their last, as every year they carried much new material; because the knot-hole was so small, they dropped many twigs, much grass, weed-stalks, and many feathers before our door. During their building time, as a protection to them, I spent much of my time on the back porch sweeping away the débris they dropped at the entrance, so that my mother seldom saw the worst of it. As the years passed, I 


\section{FRIENDS IN FEATHERS}

noticed how she protected the birds; how often and proudly she called the attention of visitors to the beauty, activity, and musical ability of her tiny tenants, so I came to realize that her threat to nail the hole shut was caused by momentary annoyance; if anyone really had driven away the Wrens, there would have been serious trouble at our house.

Any knot-hole around a house, or outbuilding, or small hollow in a tree, any kind of box you could mention, tin can, or gourd, will serve them. They will fill a box designed for Bluebirds with twigs one never would imagine they could carry, build their snug, soft nest of feather-lined grass and then wall up the large opening with protruding twigs until neither Bluebird nor Sparrow can force entrance. Householders often tell each other of the (queer places in which they have found Wren nests. Quite the most peculiar of my experience was a sprinkling can. A woman I knew inverted it in the crotch of a tree to drain after watering her flowers. When she next wanted the can, she found it filled with twigs, perfectly full, and occupied by a Wren, so she wired it in its position and bought a new sprinkler. I man once told me of forgetting his coat hanging over a fence rider and finding a Wren nest in the pocket when he went to bring it, the following day.

The only nest I ever reproduced of hundreds that have surrounded my habitation all my life, was in a section of hollow tree I had set up on our grape-arbour for Bluebirds. The place abounded in boxes especially designed for Wrens, but each year, straight to the Bluebird box went the first pair, leaving the Wren boxes for those coming later. So one year, before their arrival, I set up the Bluebird box and wired it in place, instead of nailing, lightly fastening the roof. When I felt lyy the best count I could keep that the hen had finished laying and was brooding, I carefully lifted down the box while she was from home, and removed 


\section{HOUSE WREN}

the lid. The bottom of the box was packed with a mass of twigs, enough drawn through the opening to block the passage of any larger bird, while on the top of these, at the back of the house sat the round, grassy, feather-lined nest.

The feathers so arched and enclosed it that I had to bend them back to picture any part of the interior. It was the first time I ever had touched the nest of a Wren, so unless you are well versed in Wren history you can not imagine my surprise. The eggs were very round, perhaps white for a background, but completely sprinkled with pinkish, brownish mottling, while I thought them enormous, for the size of the bird; and this you will scarcely credit, yet if you take an enlarging glass and count carefully you can see most of them, for there were nine. I tried to arrange them so all would show, but the nest was so round they would roll together, while I was in a hurry to finish and replace the nest before the mother bird returned to join the father, who was angrily scolding me and constantly darting at my head. He was quite as pugnacious as any Jay I ever worked around, so I made two hasty exposures, then closed and replaced the house. As far as I could see the mother did not know it had been moved; she entered with no hesitation on her return and settled to brooding, while she did not come out again that forenoon. None of the other boxes were ever touched.

I fully intended to open this box, make friends with the young and try to take their pictures as I did those of other young birds; but when I thought, dating from the beginning of food carrying, that it was nearly time to begin, I was called from home on business; when I returned the nest was empty. So I have no studies of the young, which must be too cunning for words, if they are reproductions in miniature of their elders.

The Wren has so many endearing qualities one can scarcely enumerate all of them. He is a beautiful little bird, having a 


\section{FRIENDS IN FEATHERS}

back of bright, strong brown, touched with deeper bandings almost black and white; his mottled breast more grayish, his eyes beady black, very large from long ages of being nestled in the dark, bright like those of a squirrel. The female is similar to the male, possibly a trifle lighter in colour, both active as if jointed with springs of fine wire that keep forever setting them off. They fly constantly in building, while if all nests contain nine eggs, the reason they work ceaselessly in feeding is apparent. They constantly chatter and sing about the business of living.

Possibly some recorder of bird song has reproduced their notes; I never have seen such an attempt, I would as soon try to put the gurgle of a brook on the staff as the notes of a Wren. The female talks volubly; the male has two periods of eoncert work; the first on his arrival, which occurs several days before the hen makes her appearance. He comes and spends the time going in and out every available location, often starting several different nests, so she is sure to be pleased with some one of them on her arrival. As he works he sings, alternating twigs and song. His real concert comes while the female is brooding. Then he perches close his home, often on the ridgepole or doorstep, and for an hour at a time, once in a stiff spring rainfall, he sings out his little heart. One of my birds sang so often on his front stoop) I set up a camera and reproduced him in full tide of song. This picture is one link in the chain of proof that birds part the beak in song, widest on the highest notes, exactly as do humans; not "singing in the throat with closed beak" as one of our aspirants to fame as an ornithologist emplnatically states. All the birds with which I have made friends, and carefully observed afield, open their mouths and sing, many of them I have pictured in the aet and reproduced in this book, as the Cardinal and the Jay; the exception being minor strains, warbled to the finest thread of a 



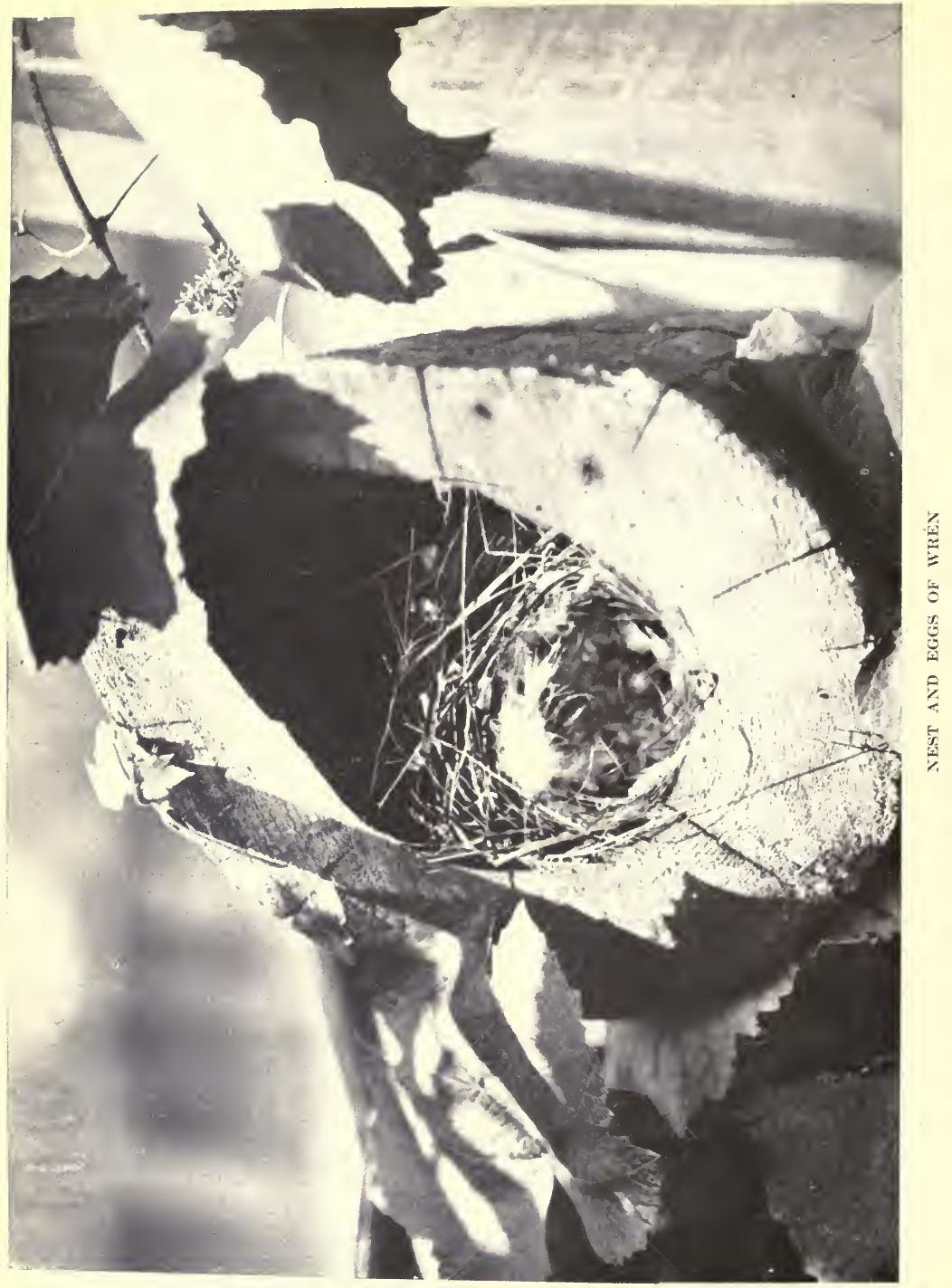




\section{HOUSE WREN}

whisper, like some of the thrush notes which prelude and close their high strains delivered with wide beaks.

Wrens are troglodytae, and so sing much like Mockingbirds, Thrushes and Cat-birds, the difference being that all these deliver their melody in measures. The song of the Wren resembles that of the others of the species in a degree, but it knows no measure; it is a bubbling outpouring too difficult to record; I judge from the fact that I never have seen any records. It is even more liquid and fluent than that of the Bobolink, which has been well reproduced by several bird musicians. The music has no high rating as melody, the prepossessing thing about it being that it is so constantly and so happily delivered. A season at the Cabin without the music of a Wren would be my "Hamlet with Hamlet left out."

Because it is mercenary, and I am not, I put their benefit to man last. Consider this one pair, having eleven mouths in the family, carrying one unceasing stream of worms, spiders, grasshoppers, from first peep of day to dark night, and then try to estimate what their presence means on your arbour, or in your garden, or among your fruit trees. In feeding they do not regurgitate. The young take the insects as gathered with the stripping of wings and the largest legs of grasshoppers, and the peeling of the hardest outer wings of beetles. All food I ever have seen taken was living, while they covered the widest range of worms and insects I ever knew one pair of birds to use; and the very largest for their size, as I think you will agree from these pictures of my Wrens, and those I made at Bob's house which are the birds of the oblong box.

Bob had placed his box on a very high pole, so that it would be out of the reach of cats. When the affairs of his Wren family were engrossing, he became so interested he asked me to come and take their pictures. They were quite as attractive as he thought 


\section{FRIENDS IN FEATHERS}

them and illustrating their benefit to man as insect exterminators splendidly; so I set up my highest step-ladder in front of their door. The box was so high, I was forced to stand on the top of the ladder and build up the shelf to hold the camera.

The garden soil was mellow, the boxes erected for the camera heavy; with my weight added the back legs of the ladeler sank pitching me over in a headlong fall, which wrecked my best camera, ruined one of Bob's finest plants; but did no damage to the Wrens. They scolded me soundly for the commotion caused by my fall.

These are birds I would urge everyone to befriend in any location and to attract to their own grounds wherever possible. They are such tiny mites, so friendly and saucy, unceasing singers of song more pleasant than silence; beneficial to an extent that places them in the front rank of birds worth courting until they make their home with you.

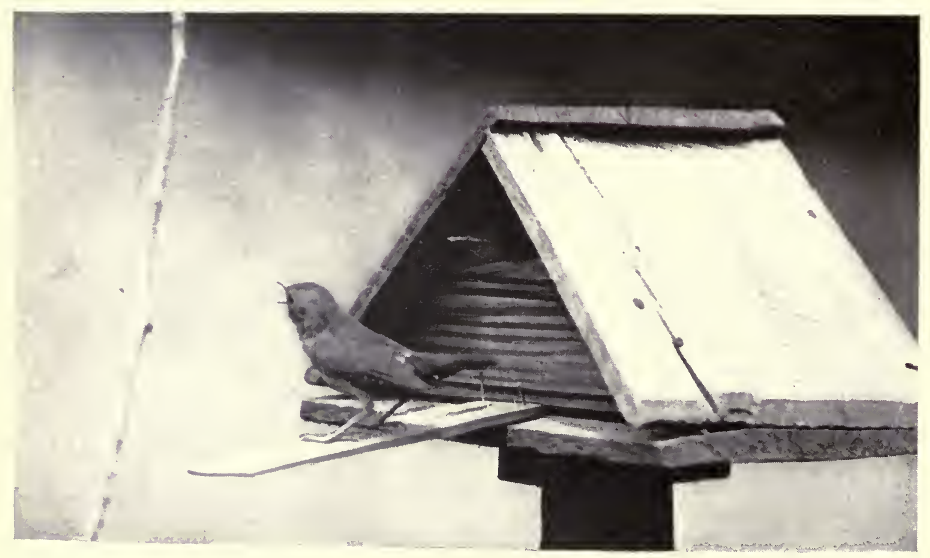

MALE WREN SINGING 


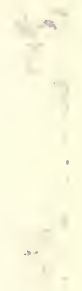

,

$\therefore-$ 


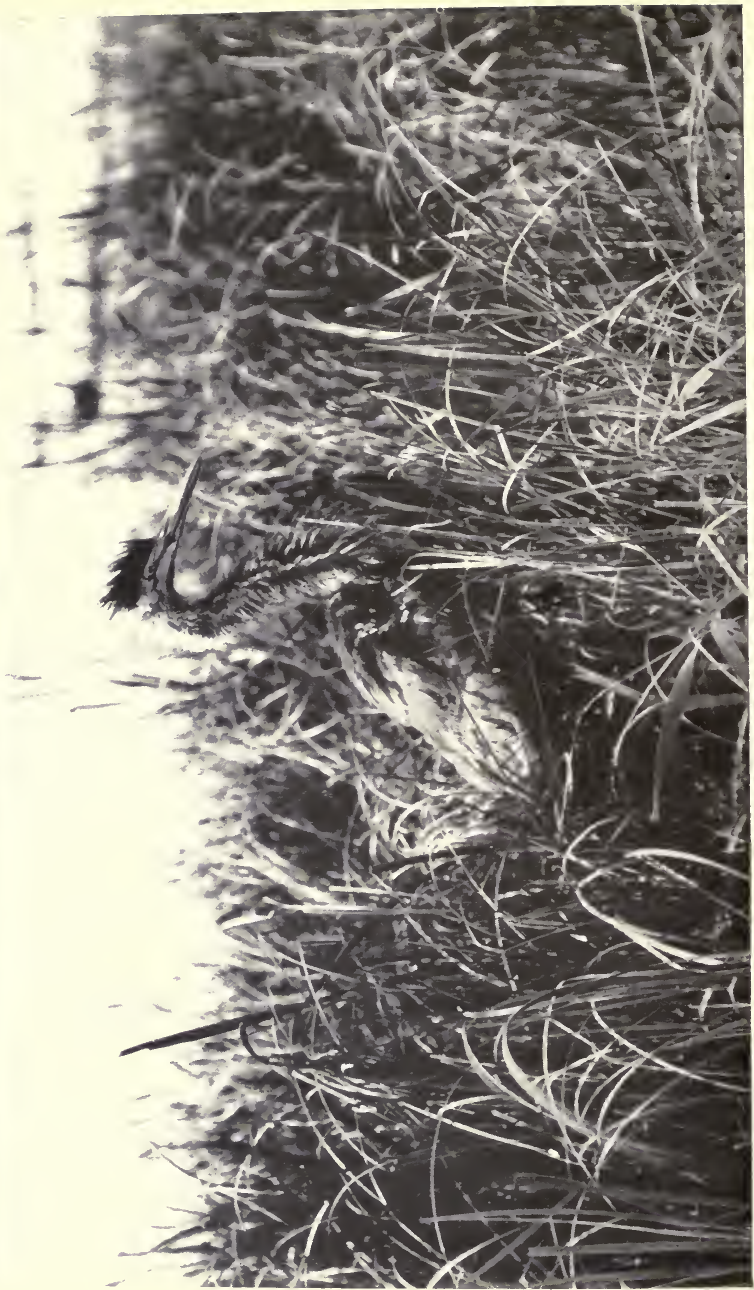




\section{FRIENDS IN FEATHERS}

pare a pair of deer horns for mounting, so I slipped away to search for the haunt of the Heron.

The row up the river was delightful. For once the veil of nature was lifted everywhere. I could see as far as my eyes could penetrate, while even the water hid no mysteries. The air was clear and cool, touched with the odour of balsam, and sweeping in light breezes. The sky was a great arch of blue, with lazy floating clouds; the sun not too ardent in his attentions. On either hand the marsh"was teeming with life. There were tracks beside the water edge where deer and bear came down to drink, small waterrats and beaver lived in the banks, and in the rushes were Duck, Teal, Plover, Heron-every kind of northern water-bird you could mention. This river was the first of my experience to give up its secrets. The bed was white sand, washed of every impurity by a swift current, while the water was pure and clear. At a depth of twenty and even thirty feet I could see every detail of the bed.

I have not time to tell of its wonders and mysteries in mineral formation; its dainty growing vines and mosses. But the water folk! If you never saw such a spot you can not dream how beautiful it is. The flowers on the bank or the birds and butterflies of the air were not more gaily coloured than the fish of that little river. Every shade of silver was striped and mottled with green, yellow, blue and red. Pike that seemed half as long as the boat swam past or darted under it. Big black bass, the kind that wreck your tackle and keep it, swam lazily unless moved to a sudden dart after small fry. There were a few rainbow trout, innumerable speckled perch, shad, and the most beautiful big sunfish. Occasionally an eel, monster turtles, sometimes a muskrat and a few water-puppies came slowly into sight and as slowly vanished. Oh, I could not row very fast on that river! And it was no wonder Herons and Cranes stalked with slowly lifted feet 


\section{THE BLUE HERON}

beside those banks, no wonder Kingfishers poised above that water by day, or that raccoons flattened themselves and lay immovable while they fished for frogs by night, for all of them could see their prey plainly and know exactly how to capture it.

I pulled into the lake, took my bearings and started toward the point where the Herons seemed to congregate. On reaching it I found the remains of an old saw-mill. The shores of all these northern lakes and rivers were dotted with mills a few years ago. There was an oozy landing-place on sawdust foundation, while the old mill probably would collapse in the first wind-storm. I pulled the boat up on the landing and entered the mill which was a shed, the floor half covered with water. Many boards were lacking, but enough were left to shelter me, so quietly creeping to the back end where the mill had been built over the water on purpose to float in logs, I saw an interesting sight.

The rushes had grown through what formerly had been a bed of sawdust, until they almost reached the mill. In this rotten sawdust there seemed to be a big white worm, of which the Herons were fond, and how they did gobble frogs! Undoubtedly the old mill was the attraction for both frogs and birds. The story was told in nature's plainest writ. The sun shining on the watersoaked sawdust raised a sweetish, sappy odour. This odour attracted flies and other insects in myriads. The insects in turn lured the frogs. The frogs made a feast which called up the Herons, while the Herons furnished subjects for my cameras. Inside the old mill, so close I could almost reach out and touch the actors, I interpreted these "signs."

Surely I am qualified to tell how a Blue Heron catches frogs. There is no hunting; his prey comes to him. The big birds, some of them over three feet in height, came winging across the lake, selecting the spot from which they wished to fish, quietly 


\section{FRIENDS IN FEATHERS}

alighting. After looking carefully around him, each bird would move several yards, stepping high and with great care, flattening his body and slipping between grasses often taller than he was. When he had selected a fine location he stood perfectly still, mostly on one foot, his long slender leg seeming so like the cattails and rushes as to be unnoticed; folded his wings tight; drew in his neck; pointed his bill at an angle of about twenty-three degrees before him, and went to sleep-apparently.

This was queer liunting. I wondered if it could be possible that those Herons left their nests in the tall timber across the lake, came over there behind that old mill and stood in the water among those rushes to sleep. The first pounce that was made straight in front of me startled me so that I almost cried out. After a lifetime of field work I cannot suppress a sort of breathless snap of an "Ow," when I am surprised. It is a cry to which a bird rises every time. I barely saved myself. The thing was so unexpected. There stood the Heron, a big fine fellow, the light striking to brilliancy the white of his throat, wet with dew from the rushes, the deep steel-blue of his back, and bringing out sharply the black on the flattened crest and the narrow line down the front of his throat.

I had not seen a frog climb to the sawdust in front of the bird, so intent was my watch on him; so tremblingly was I setting up my camera and focussing, in an effort to get everything just right and avoid his seeing me slide the camera before the opening beside me. I was wondering if he possibly could hear the shutter, or if the plate could be changed before he did something more interesting than sleep, when snap! like a machine, out darted the Heron's neck, clip went his shear-like beak, then it pointed skyward, crest flat, the frog was tossed around and caught headfirst-one snap, two, it was half-way down the gullet of the bird, whose beak was drawn in, crest flared and chin raised, before I 


\section{THE BLUE HERON}

recovered from my surprise enough to remember that I held the bulb in my hand and must squeeze it to secure the picture.

Hurriedly I shoved in the slide, whirled over the holder, set the shutter and drew the slide again. The bird had turned and moved several feet toward me, coming more in the open. I set the focus by scale and snapped again. That time in my eagerness I moved out too far, he saw me and away he swept, several of his fellows nearest following. I put away the plates and tested my focus on the spot where he had been. It seemed sufficiently sharp for a fine picture. Developing the plate proved that it was almost as nice a piece of work as I could have done if blest with plenty of time.

Then I glanced over my background. For a Heron picture it scarcely could have been improved. The mill stood in a small bay. Behind it rushes grew in a tangled mass, the body of the lake crept close to them, out in the water a couple of runaway logs were bobbing in the sunlight, while in the distance a far shore showed faintly. There was only one thing to keep me from having fine natural-history pictures. The bird was dripping with the heavy dew of the swamp; but if I had reproduced his head sidewise, with his bill and one eye, and the frog going down, surely that would not hurt my picture. In fact, thinking it over, it seemed to add to the naturalness of it and help portray the damp, swampy atmosphere.

Then I heard voices, the splashing of water and remembered that I was alone. I caught up my tripod and carrying case, tumbled them into my boat, pushed off and jumped in, not a minute too soon. I pulled into the lake barely in time to miss a crew of half a dozen men coming around the shore driving a $\log$ float and gathering up stray timber. When far away from the logs I put away my paraphernalia, set a small hand-camera in reach on the seat before me and started down the river. 


\section{FRIENDS IN FEATHERS}

The day had grown slightly warmer, but that was made up for by rowing with the current, for after entering the river I need not pull; but by steering could travel quite as fast as I desired. On that return trip my first muscalonge showed himself. Really, in the water it appeared as long as my boat. The fish must have weighed fifty pounds. It was only a short way in the river mouth, bewildered, no doubt, by the clear water, for it turned almost beneath my boat and went back. A magnificent big fish it was. My attention was called to it by the commotion caused among small fish darting in all directions to escape it.

On my way back I had a shot with a small hand-camera at a Heron on wing, but it was so far away that developing the plate disclosed only a speck on the sky. I tried some Plover and a Duck with better results, but that is another story. This is of the Blue Heron, and is one of my best pieces of work, quite by myself.

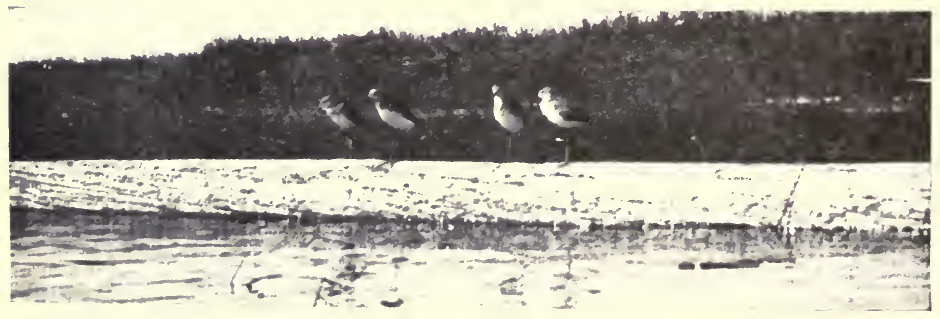

INDIAN RIVER PLOVER 



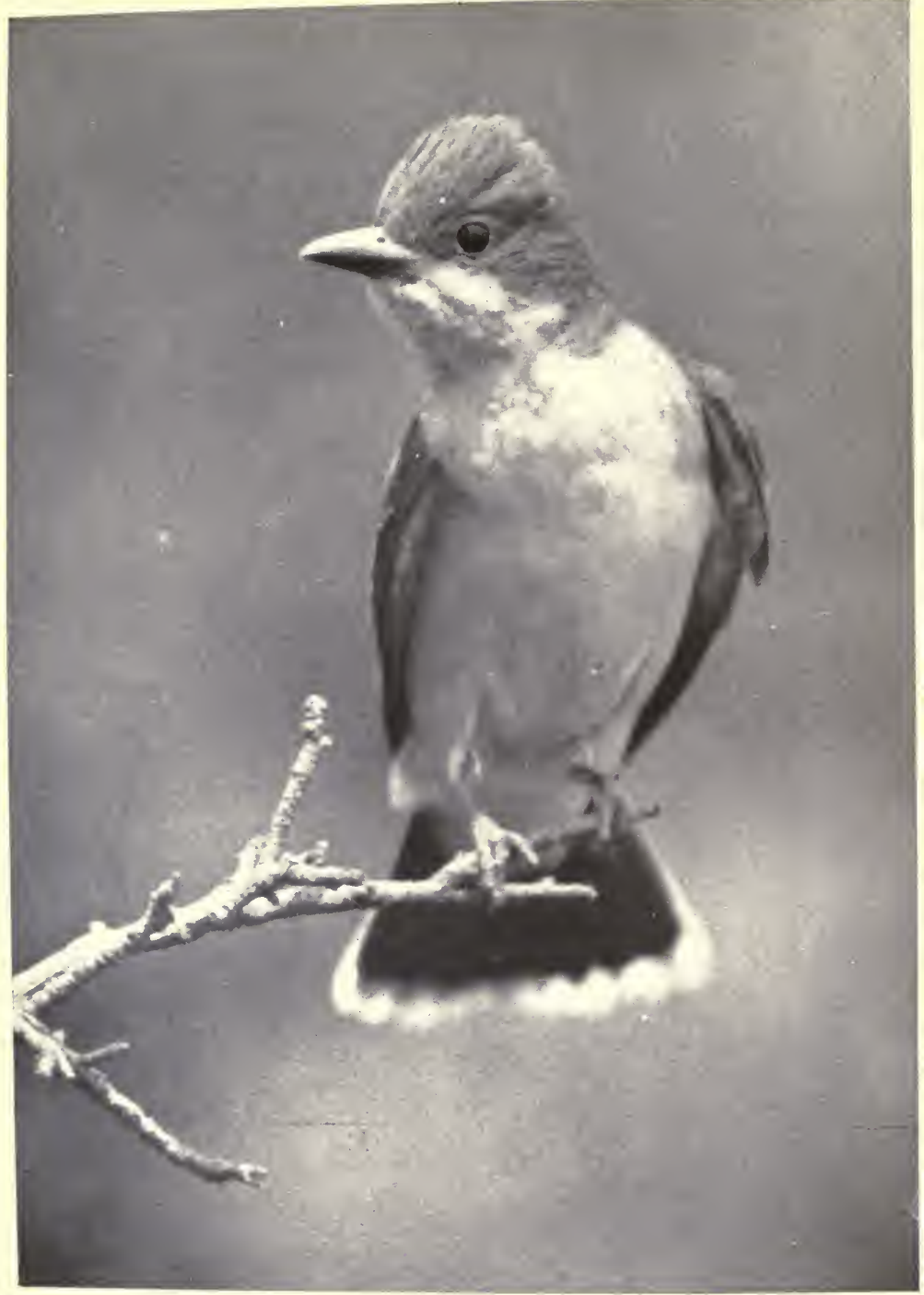

THE MALE KINGBird WEARS A CROWN OF GOLD 


\title{
CHAPTER XVIII
}

\section{The Kingbird: Tyránnus Tyránnus}

\author{
IN ORCHARDS
}

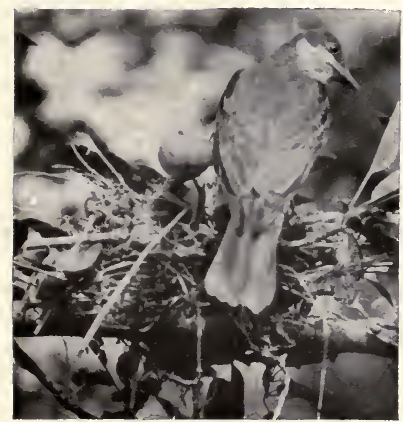

FEMALE KINGBIRD WATCHING

CAMERA WHILE AT NEST

Вов found the nest of the Kingbird through seeing the father carrying a small white moth to a branch of the winesap in the Aspy orchard. When I arrived the babies were, perhaps, three days old. I did not feel bad about this as I had in my negative closet in the Cabin a good reproduction of the most attractive Kingbird nest I ever had seen. It was built in a small walnut-tree on Bob's lease. Besides being the neatest and most firmly built of any Kingbird nest of my experience it was decorated. There was a liberal lining of wool gathered from fences, the front of the nest deeply bordered with tufts of wool, part from black sheep, the remainder from white; the finishing touch being a knot and drapery of cotton cord, tucked into and looped across the wool.

In this dainty nest were three delicately coloured eggs, although the number often runs to five, four the average. The eggs are as beautiful as those of the Oriole. They are large, for the size of the bird, rounder than is common, deep cream colour quaintly touched with brownish markings as if painted on with a brush; between them fainter decorations of grayish lavender. 


\section{FRIENDS IN FEATHERS}

Bob improvised his dummy camera from some stakes, an old soap box and a hen's nesting box, the day he found the birds. That night he told me of it, so I was in the orchard early the following morning; by the size of the birds, about the third day after they hatched. They were so tiny I could not risk work on the nest for fear the mother would become frightened and leave the young so long they would chill. Very carefully I took down the temporary tripod and substituted my highest step-ladder. On the workman's platform of this ladder I set the soap box lengthwise, then bound it fast. I placed the nesting box on that and made it secure. Then I went about my business with other nests in the orchard; returning slowly, always when the elders were at the nest, a dozen times that day to climb the step-ladder and go through the motions of taking a picture. It night, before leaving I removed the ladder and boxes as I feared boys playing at the river would see them and find the nest.

Two more days I kept this up, each time going closer and remaining longer until the old birds went on with the affairs of life, paying not the slightest attention to me. The fourth day I set the camera atop the hen's nest, but it was still too low to bring the Kingbird family in proper focus, so I added my carrying case to the top of the erection and set the camera on that. This brought my improvised tripod level with my face, when I stood on the top of the ladder, while the birds were in exactly the place I wanted them. After a brooding, and two feeding exposures, I took down the boxes, moved up the ladder, and covering the nest with my hand began making friends with the tiny pin-feathery babies. Both old birds flew into the tree and came closer than I thought they would, but neither made a sound, nor did the young. That was enough for one day, so I went away, as quietly as possible.

Each day for nearly a week this went on. Sometimes I 236 



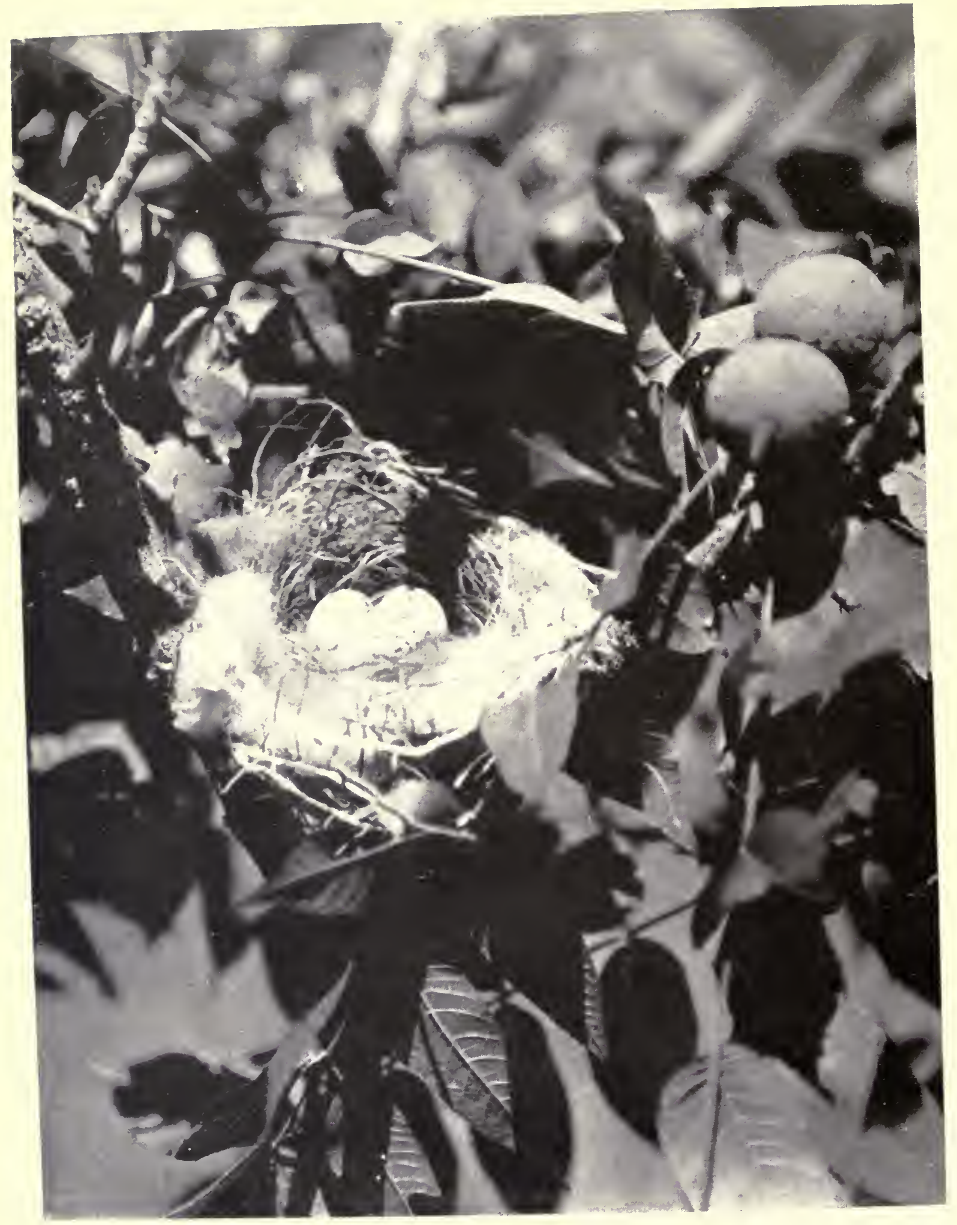

NEST AND EGGS OF KINGBIRD 


\section{THE KINGBIRD}

did not make an exposure at all, merely worked around the nest, taking the young from it and setting them on my fingers, or the closest twigs, then with the utmost caution not to frighten or hurt them into the impulse to flight, I put them back. By that time I had made such friends with the Kingbirds that I began taking people with me, one at a time, and leaving them under the closest tree to watch how I could fellowship with the tyrants of the orchard, for that is exactly what they were. The Vireo and Song Sparrow were sorely afraid of them, the Cat-birds flew wildly when the old Kingbirds intimated it would be better that they should; the Doves and Brown Thrush kept out of their way, the Blackbirds never stopped to quarrel, neither did the Shrike; I marvelled at that, surely they are bigger and stronger; while they have a worse reputation as fighters; but they did not fight the Kingbirds, although their nest was not far away across the road, and they hunted in the orchard. Without hesitation the Kingbirds attacked the Crows, flying above and picking their heads and eyes, while one day Molly-Cotton and I saw them chasing a big Hawk across the sky in the same fearless manner.

That was the day we secured our great picture. While making friends with the old birds I sat for hours under the bellflower where I could see the nest plainest and watched each smallest detail of Kingbird family life. I knew what they fed their young, how they hunted and prepared their prey, cleaned their nests, and conducted themselves toward each other. One thing I especially noticed, because it was of much help to me in my work. As in so many other cases these birds each had a route, always the same, by which they came to and left the nest in feeding. They did most of their hunting on the grasses of the orchard often taking small moths on wing in air. In carrying food to the young the hen invariably arose to the tip-top twig 


\section{FRIENDS IN FEATHERS}

of the winesap, from there dropping to the nest. 'The male always flew to the closest branch of the next tree, and from there sailed across to the tip of the small branch on which his nest was placed, among several leaf and fruit-bearing twigs, one apple being directly beside and above the cradle. The point of the limb was dead and dry, the tree being badly infested with scale.

Each time he alighted there he made a perfect picture. There was nothing intervening, clear sky background, while as these birds feed by regurgitation, there was not even a bug in his beak, to obscure its shape and cutting. It was not so long as a Robin's, but suggested it. His eyes were large, bright, strongly rimmed. His back was deep slate gray, his wings and tail almost black, his tail deeply bordered with white at the tip, also the tertiary wing feathers were white-edged. His deep, full-feathered throat was very white, so was his breast, gradually darkening to gray on the underparts. He had a round erest he could erect at will, of much the same gray as his back at the feather tips, the remainder yellow. This you will scarcely credit, but in full light, with crest erected, on his head there was a strong gleam of gold, and were I painting him in this position I should put it in.

Each time he alighted on the twig, which was as often as he fed his young, possibly ten times an hour, he displayed his every attraction. I pointed this out to Molly-Cotton, then suggested: "As they are such good friends with me, and so well accustomed to the eamera, why not move it a few feet to the west, directly in line with where it is, and take his picture the next time he perches there?" "If he will come in front of it, we can move the eamera," said Molly-Cotton. So I staked off the exact spot where it should stand, then one on each side we placed the ladder with its erection of boxes, put the camera where I had marked 



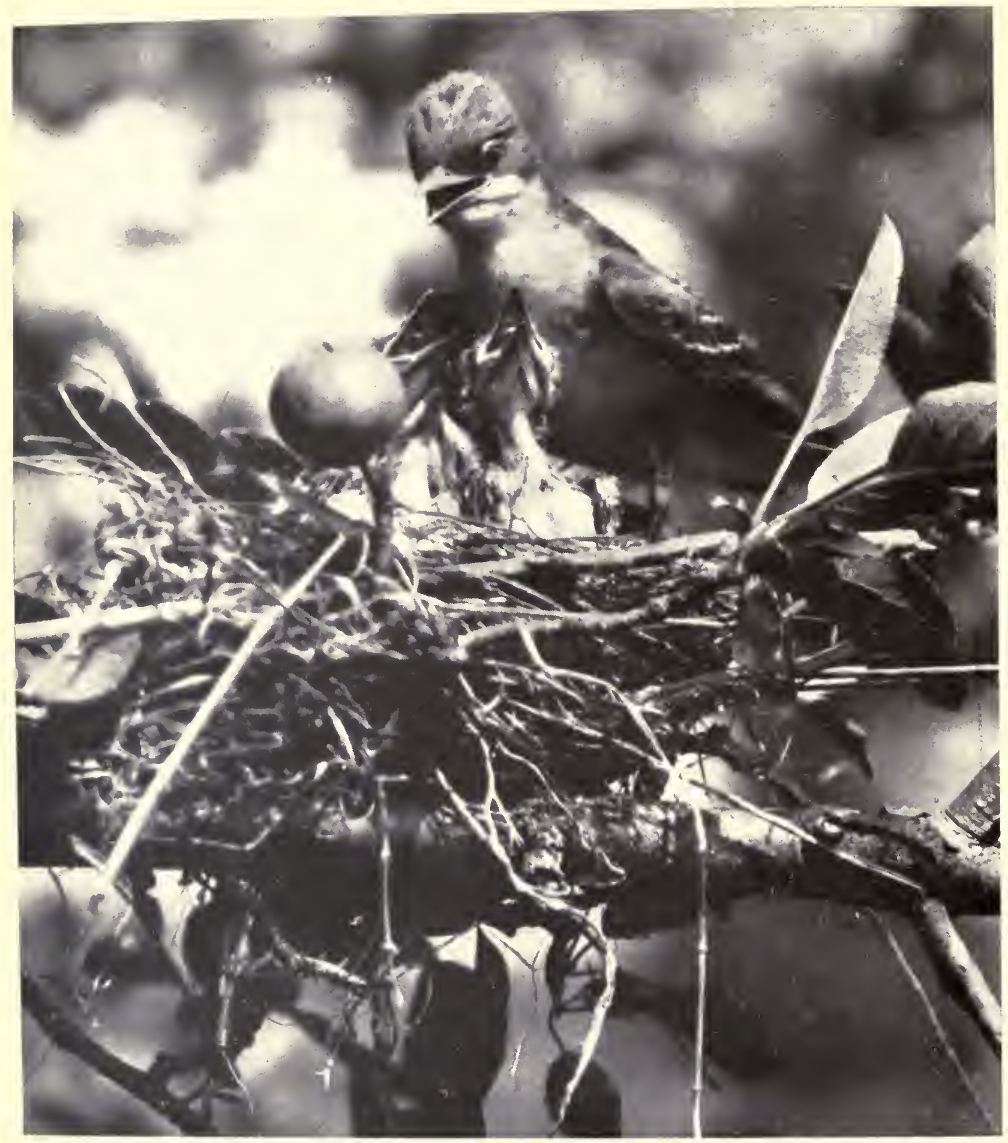

MOTHER KINGBIRD FEEDING YOUNG BY REGURGITATION 


\section{THE KINGBIRD}

the top box for it, and without focussing took the long hose and went back to the bell-flower to wait.

The first time he came he alighted as usual, but noticing that the camera had been shifted he slightly drew back, lifting his wings a trifle. At that instant, thinking he could not possibly appear better and might fly, I made the exposure. He was dubious, but as no harm had come from the camera previously, he decided none would now, for he studied it an instant longer, then flew to the nest. I was so sure of the exposure I replaced the camera and that night developed the plate, which was so perfect I did not attempt to better it. When I had this study, the old birds, both male and female in every position I could think of, back, front and side, brooding, and in the very act of regurgitating food and emptying the cloaca, I began on the young.

They were easy. When the feathers were developed enough that the babies would appear well, I began by using a second step-ladder to reach the nest, carrying in my pocket the long hose bulb from the camera on the other ladder. Reproducing them consisted of climbing the small ladder, placing them as I chose and then squeezing the bulb. Three showed nicely on the edge of the nest, the apple taking the space for the fourth, so I set him on the limb beside the nest. When I had made all the exposures I thought I ever should want of the grown and young Kingbirds in the nest, I coveted one more picture of the young the last day before they would take flight. This fell on Sunday, as I figured their history. I was afraid to wait until Monday, for they appeared so large I thought the impulse to flight might come at any time, while my studies of these birds were so perfect I felt I could not miss this crowning one, also I would be forced to make a business trip Monday. I thought and still think I shall be forgiven, for I drove to the orchard Sunday afternoon, set up and focussed a camera on a scraggly dead limb of a 


\section{FRIENDS IN FEATHERS}

brush-heap of apple-tree trimmings, three tree locations distant from the winesap, then went to the nest and took from it all the babies, carrying them in the crown of an old hat. Then in the range on which I had focus I set one baby full front, one three quarters, one side, and one showing as much back as possible, and made several exposures. While I worked both old Kingbirds waited on their favourite perches watching me. Neither took flight for any reason or made a sound. When I had finished I replaced the babies in the nest and left them, thinking they surely would go the following morning. As I was compelled to leave home early Monday I cautioned Boh to watch for me. His report was that the first of the young had left the nest at ten o'clock Tuesday.

These are of our most pugnacious and tyrannical small birds. I recall no others so fearless in attacking birds as large by comparison as Chicken Ilawks, even; yet in a short time, by moving quietly, remaining near them, using merely the precautions suggested by common sense, I secured these pictures of them during their nesting time, in their own location, posed exactly as they naturally placed themselves. In handling the young, I first covered the nest with my hand, then slipping in a finger worked it under the young bird I wished to make friends with until I found its feet and got it to grip as it would on a twig. Then slowly and cautiously I raised it, gently removing my hand from the nest to cover the bird and so hovering it until I wanted to place it on a twig. Then I would hook its back toe over the limb, slowly rolling my finger forward until its front toes would close over the twig, still keeping it covered until it was contentedly settled. In putting them back I began at the long middle front toe and rolled my finger under each foot, all the time hovering the bird with the other hand, then replacing them in the nest in the same manner. It required all of half an hour to take these 


\section{THE KINGBIRD}

four birds from their nest, and quite as long to settle them as I wanted them, but I did it repeatedly, even carrying them from their tree to the brush-heap. Never once did I hurt one of them so that it chirped or made a sound, else the old birds would have called excitedly and spoiled everything. The whole battle in handling young birds is to a void the first sound of a cry on their part, to prevent the least fright or hurt that will cause an impulse toward flight. If they can be taken from the nest the first time and replaced, the remainder is easy. I have done this all my life, but I was born with an extra sense pertaining to field work, I have unlimited patience and time to spend on a series I desire; so I secure such studies as this book contains without ever moving a nest, or injuring young birds, or driving away the old ones from their location. To anyone desiring to do like work, these are the only possible methods to pursue. The instant a nest is moved, the old birds may go to it, but never naturally, nor will the nest be natural, while it is utterly impossible to take a young bird in the fingers and lift it from the nest, as it will grip the bottom, bringing it up with it, struggle until it cries out with pain, and become so frightened that it throws the other young and the elders into panic.

Because these notably pugnacious birds responded so beautifully to my advances and we became such fast friends, I grew very fond of them. They are the bravest birds of their size, they love homes and orchards for nesting locations, they are beautiful perching or on wing, they are invaluable in any orchard or meadow, taking their food on wing, so that they exterminate a number of pests not molested by other birds. They dart from high perches gathering small moths and picking worms from grass-blades until they have all they wish to take at one time, then fly to the nest and regurgitate the food for the young.

They are cheerful and rather constant talkers, what they say 


\section{FRIENDS IN FEATHERS}

is interesting, but if you ever read that they utter musical notes or make any sound approaching song, lay the statement to overenthusiasm on the part of the writer. If any male bird ever sings, he does at mating and nesting time. The illustration of this chapter is only a small part of the Kingbird history I have recorded photographically, while I have been familiar with the bird all my life. The year following the taking of these pictures a pair of Kingbirds eame into the village, courted, nested and hatehed their young in a bell-flower apple-tree at the Cabin. opposite the back door, so that I saw them constantly and heard most of the sounds they made. I listened by the hour while the courting, building and brooding was in progress, but I heard neither musical notes nor connected song. When it comes to music they belong in the same class with the Shrike.

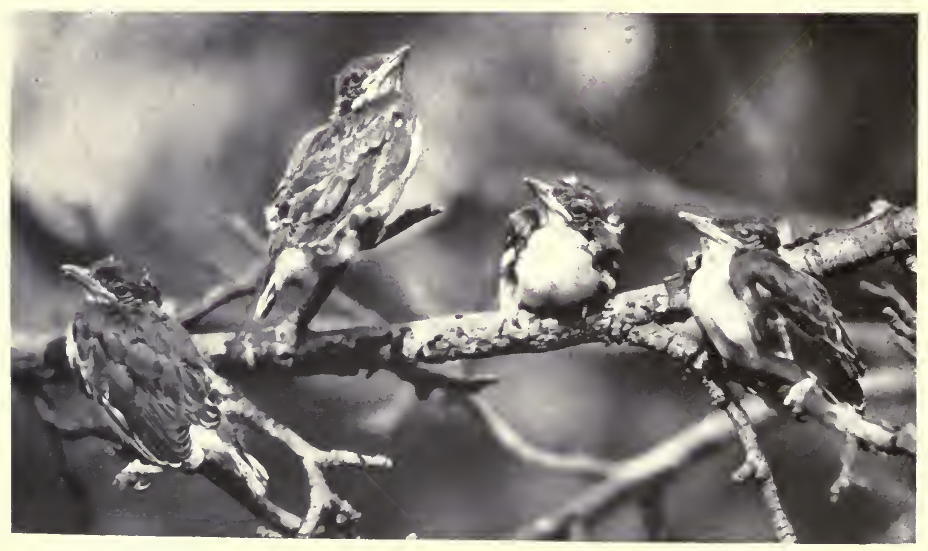

KINGBIRD YOUNG 



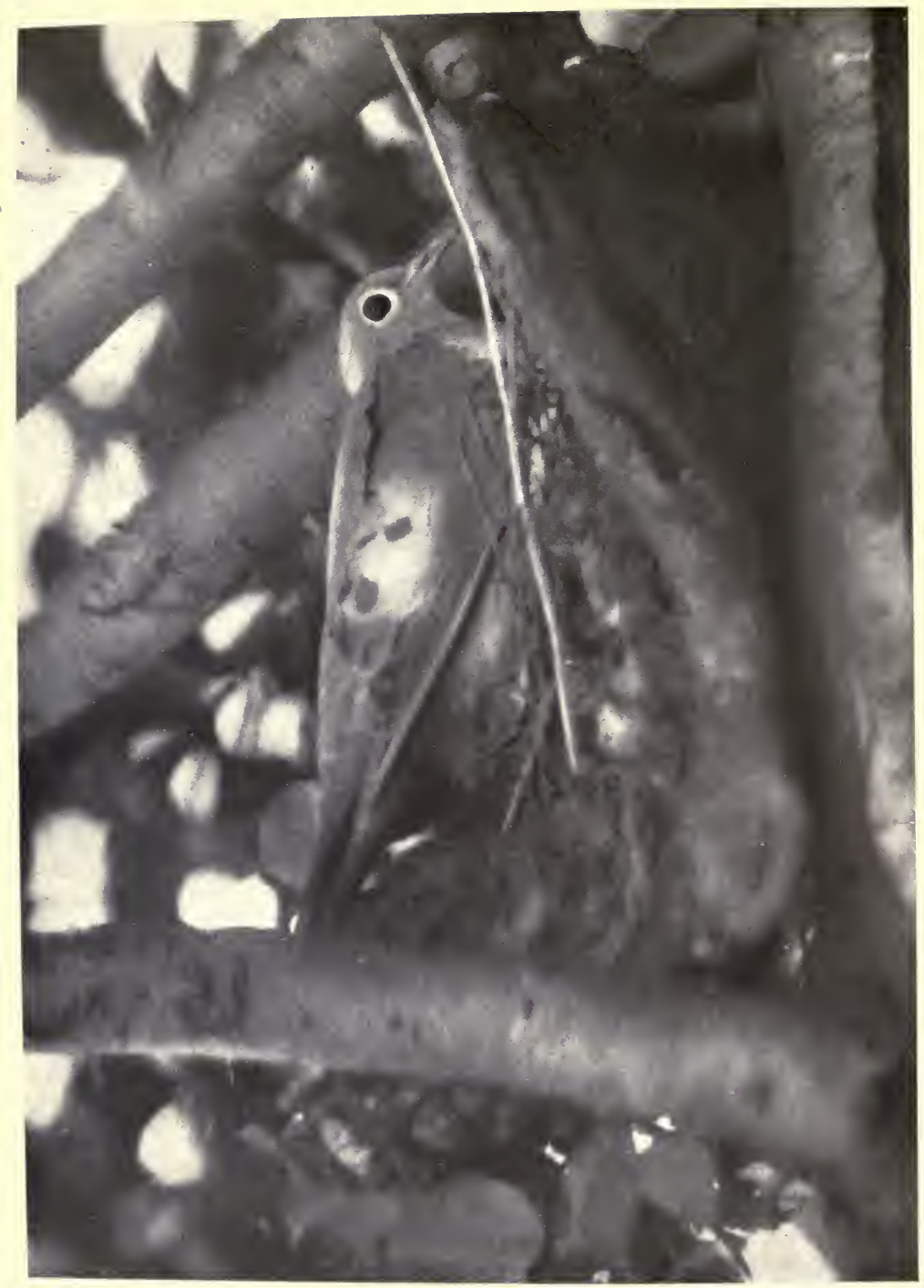

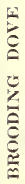




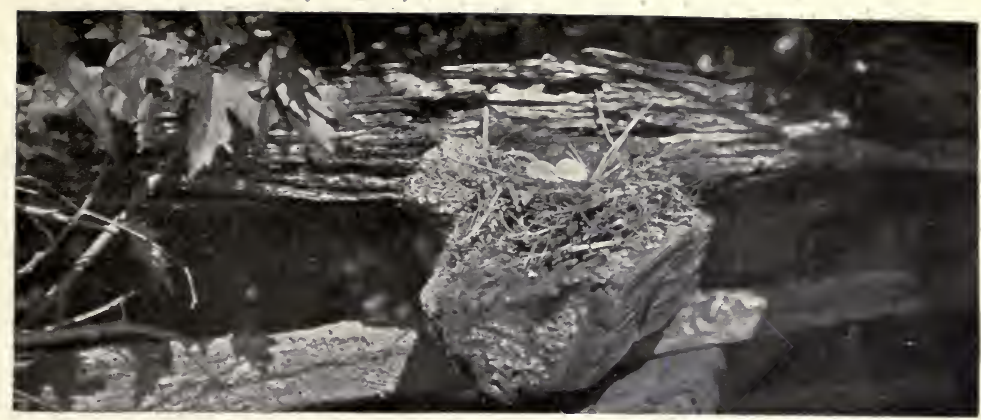

NEST OF DOVES ON THE FENCE OF ASPY ORCHARD

\section{CHAPTER XIX}

\section{The Mourning Dore: Zenaidura Macroura}

\section{IN DEEP WOOD}

Tris was one of Mr. Black's original forty nests. It was the most beautiful Dove nest of all my experience. Five rods south of the Cat-birds, on the same fence, the Doves had located. They had laid a foundation unusually sure on the flat surface of a top rail, where the rails cross at a corner. Almost every day in field work I wish that colour photography had come into actual, practical, every-day use. This structure and its surroundings made me wish for colour more fervently than usual.

The fence was very old, in fact such a deep steel-gray as to be almost black, veiled in a delicate mist of lint and well covered with crimply lichens running the entire colour scheme of gray and green. The nest, as you will observe, is not typical. These birds are famous for their careless architecture, a handful of 


\section{FRIENDS IN FEATHERS}

coarse twigs artlessly laid in any thick shrubbery or evergreen being the rule. Frequently I have been able to tell whether a Dove's nest contained eggs or young birds by standing under it and looking through the bottom.

This nest was built of fine material, and no doubt to make it inconspicuous, everything used in its construction harmonized with the shades of colour on the rails, until at a distance, seen on a level with the rail, it appeared like a knot in the wood. There were two delicate, opalescent white eggs in it, as is the rule, while all around and orerhanging it was a thicket of maple sprouts.

I have made studies of Doves" nests in March, when there was a skiff of snow on the ground, all the way through the spring and until July, in every location, and of every construction imaginable, but this was the most perfect picture and the most individual piece of architecture I yet had seen. I always have had a good opinion of Doves. They compel that by their charming characteristics and absolute harmlessness. These Doves gave me a deeper respect for the whole species by proving their sense in constructing this nest.

Had they piled on this rail a rough little heap of their ordinary construction, I should have said: "Doves' usual work! It's to be hoped the eggs won't roll out!" Before that nest I held my breath.

"Oh, Bob," I cried. "Oh, Bob! Do you see what they have done? Do you see how they have kept to the colouring of the fence and built to imitate a knot-hoie, as surely as ever Flycatcher did?"

"By Jove!" exclaimed Bob. "That's a fact! I didn't know they had that much sense."

Neither did I. But now that I have seen for myself, my estimation of the whole species rises. It is things like these, small things, which set nature-students wondering. IIad these Doves 



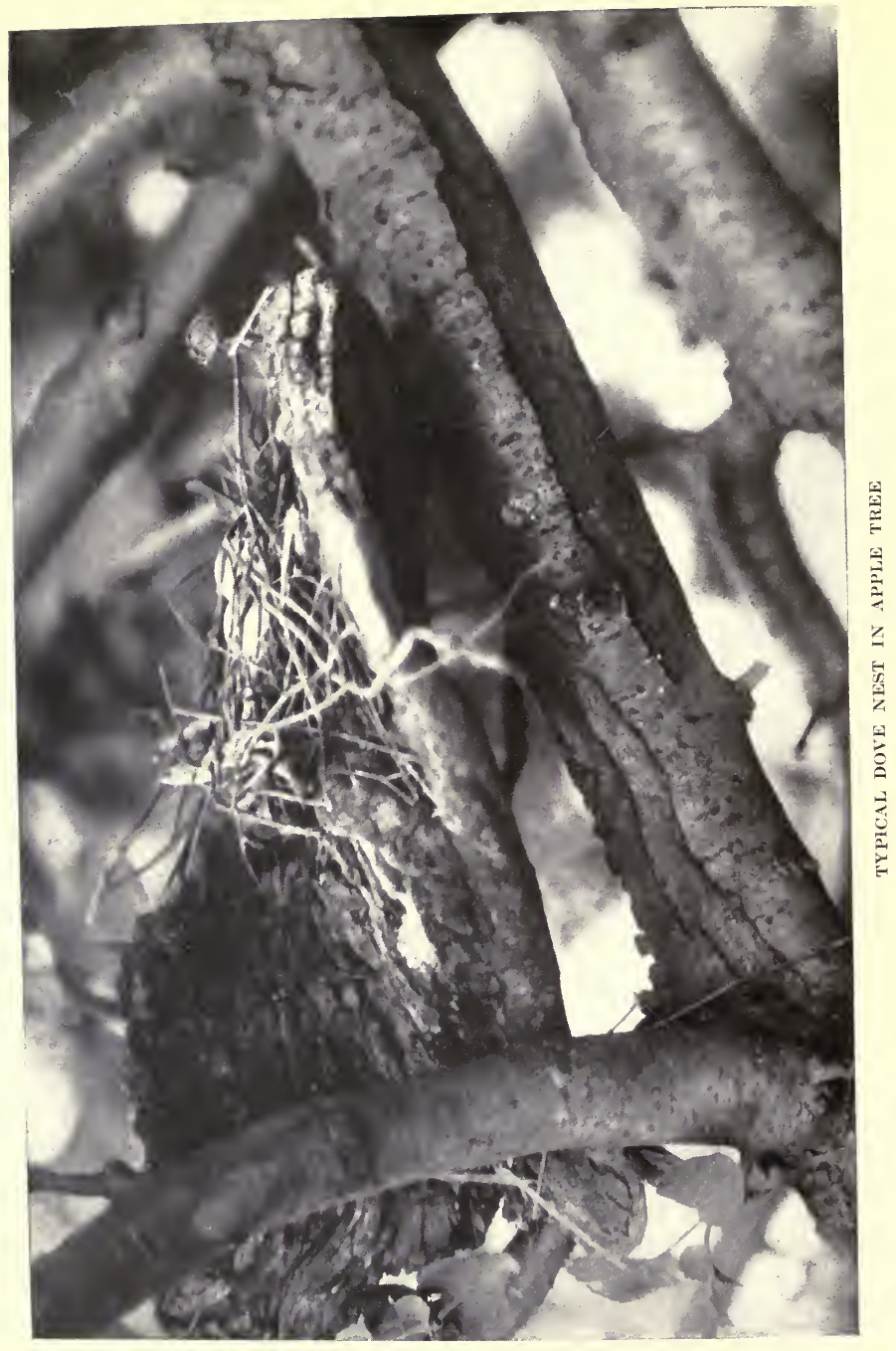




\section{THE MOURNING DOVE}

built their usual structure, ornithologists would say it was instinctive. When they leave all traces of the building of their species, and fashion a compact nest of unaccustomed material, resembling in colour the fence on which they build it, what shall it be called?

I watched these birds to see if in any other way they differed from the remainder of their family, but could detect no trait unusual with every Dove I ever had known. From a grassy couch under a big winesap closest their corner I studied every feature of their daily life and found them common Doves. They were no bigger than the average Dove, their plumage was the same, they ate seeds to gluttony, their wings whistled when they flew, they were closer the river than the road, yet they preferred to bathe in the dust. The male verified all specifications relating to him as to constancy and tenderness. He stuffed his brooding mate until she was compelled to refuse more food, then loved her until he almost pushed her off her eggs.

He always preceded the feeding process by locking bills in a caress, then stroking her wing, then a bite and another caress and locked bills at parting. When she would not take any more, close against her as he could crowd he perched on the rail until she frequently had to push him away to keep her carefully built nest intact. I loved to watch and study them. I was waiting until brooding had progressed a week or so before beginning a series of pictures of them, when Bob with a discouraged face, met my carriage.

"Our Doves are gone," he said.

I could only repeat: "Our Doves are gone?"

"Yes," said Bob. "Aspy turned the cattle into the orchard this morning and the very first thing they did was to get into that shrubbery, pulling a limb across the nest that tore it up and broke the eggs."

A field worker must become accustomed to disappointment; 


\section{FRIENDS IN FEATHERS}

but I did not realize what I had hoped to do with those Doves, nor the extent to which I had counted upon them for something fresh and characteristic, until the dainty little nest and the pearls of eggs lay trampled and broken at my feet.

Here is another point for nature students. Having had bad luck in a low location and seen their nest torn down by browsing cattle, what did they do? Go somewhere else and build another nest as low, from instinct? They followed the line of the fence to the river-bank, and at the height of at least twenty-five feet, they built the highest nest I ever saw constructed by Doves. It was in the branches of a very large hickory-tree.

So there was no "series" of these Doves. A week later, however, Bob told me that across the river, in the woods pasture, he had found a nest the preceding day with a pair of Doves in it almost old enough to fly. We rowed across and found them still there.

These Doves had homed in a brush heap so old that the limbs were rotten and covered with a tangle of wild rose and grape-vines. I remember that the grapes were in bloom. In fact, so vividly is every surrounding of each of the studies in this book photographed on my memory and sensibilities, that though it is January and a white world as I write, I can scent the pungent grape-bloom and a rank succulent odour of green things crushed underfoot, hear the bumbling of bees and the lusty challenges to combat of a pair of Bralma roosters separated by two miles of space, as I did when working with these Doves.

The young were not so near ready to fly as Bob had imagined. That day we photographed them in their nest, which was typical, the merest little handful of twigs imaginable. They could scarcely cling to it while a heary wind would have wrecked it completely. Two days later we found them sitting side by side and made a study of them. I very nearly said we induced them 


\section{THE MOURNING DOVE}

to look characteristic, but when I thought of it, they would appear that way in any event, while we neither could cause nor prevent it. In my experience a Dove is always a Dove. If I should see one involved in an affair of honour with any other bird or pulling feathers from his mate I should think he had eaten wild parsnipseed and gone crazy.

As we worked around these nestlings from the deep cool forest came continuously the mournful "A'gh, coo, coo, coo," of the old Doves. No wonder early ornithologists thought Mourning Doves a suitable name for them. The same idea has become so ingrained with us that it is a protection to them. Even careless children respect the supposed grief of Doves, as they would that of humans.

On detailed investigation there are no happier birds. They emerge in pairs, grow up close as they can keep together all day and crowd tight against each other at night. With them there is noeager unrest and search for a mate. Excepting while the female broods, a circle of three yards would include both of them threefourths of the time, even in flight. Often on wing I have seen a male Dove forge ahead too far and turning describe a circle around his mate and come up closer to her. They are of such quiet disposition and inconspicuous colouring that they escape many of the dangers which brilliant, self-assertive birds call upon themselves.

Always there is an abundance of the seed they love best to be had for the eating, their crops eternally are stuffed to gluttony; always it is easy to find dust for bathing. Always they are together, tender, loving, and in reality cooing in an ecstasy of supreme content about it all. Mourning Doves, indeed! One might well covet such mourning as theirs.

During the year following the publication of this book, in these same locations I had the happiness of reproducing two 


\section{FRIENDS IN FEATHERS}

brooding Doves; a thing I have not yet seen done by any other field worker. After I had secured these studies, I understood precisely why Dove reproductions are not plentiful.

The first brooded on a heap of driftwood hanging on the north bank of the Wabash where it flows west through Shimp's meadow. Bob had no idea how long the bird had brooded when he found her. The location was so low I could set up my camera on the ground, but I was hampered in my movements by being forced to work through a woven wire fence on the edge of the bank, while the rapidly rising water of a spring freshet threatened to carry away the nest at any minute. The time of my first visit was five in the afternoon, later than I try, as a rule, to do field work; but on account of the flood I was doubtful whether the nest would be there until morning. So quietly and with all the caution possible I set up a camera. Focussing on the nest was slow work on account of having to push the lens between the wires of the fence, and at the same time keep the proper range. The bird sat throughout the long performance without showing the slightest inclination to move; but went with a whirr when I began to take down the camera. As the nest was in great peril from the flood I also made a study of it and the eggs, thinking very probably it would be gone before another day. I went away jubilant, believing Doves were easy and that with morning light I could secure a much better picture, as the little gray mother was coloured so like her surroundings that it was difficult to distinguish her from the driftwood.

When the light was right the following morning I approached with usual caution, but there was a whirr of wings before I came in sight of the nest. When I reached it I saw at a glance that the bird had been bound by the brooding fever the previous evening, for there was a pair of newly hatched babies in the nest and bits of shell around it. I hastily set up and focussed 


\section{THE MOURNING DOVE}

the camera, then slipped sixty feet away to await her return. She came close but would not enter the nest with the camera there. When I waited until I was afraid for the young I was forced to remove it. After she had brooded a long time, I tried again with as great caution as it was possible for me to use; again she flew before I could see her. We made an all-day business of it, also several days following were spent in futile attempts, for the bird grew wilder as the young grew older, while a vicious mare with a young colt chased me every time she saw me, so that the first exposure was all I had of the river Dove. I made several of the young to complete the series, before they left the nest.

The other nest was a few rods away, in the Aspy orchard. In beating down apples, boys had used a piece of old apple-tree trunk. It had lodged flat on a branch, hollow side up, one end firmly wedged between two green "suckers," the other against a small limb, where it had held for a season. Here the Doves had made an unusually ramshackle nest, upon which the gentle and modest-appearing hen was brooding.

An interesting time that bird gave me, not another such in a lifetime of work afield. When I began with her she showed symptoms of moving at thirty feet so I stopped right there to make the first exposure. When I tried walking the camera toward her, she went like the proverbial "flash," and would not return with me there, so I took down the camera and went away. The next time I tried I got a few feet closer before 'she made a forward impulse which warned me to stop. I made another exposure and again cautiously tried moving the camera forward. I knew the ground as I had gone close and pictured the eggs the first time she left, but there was no approach by that method. The bird would not endure having the strange-looking object slowly draw near her, so the camera would have to be carried away. An hour 


\section{FRIENDS IN FEATHERS}

later I could go back, move a foot or two closer and make another exposure. Sometimes I only pretended an exposure, but mostly I made one as her position would be different on the nest, or the light better.

After three days of this I had advanced to within less than ten feet of her. where I made the title picture of this chapter. I kept no account of the number of approaches I made, but I have about twenty exposures of her, possibly half as many times I advanced but did not use a plate. When the brooding fever was past she would not come before the camera at any distance to feed her young, while the nest was so shaded the instantaneous snap of a feeding picture would have been impossible, had she braved the camera. The young posed many times for me, so I have a beautiful series of their development.

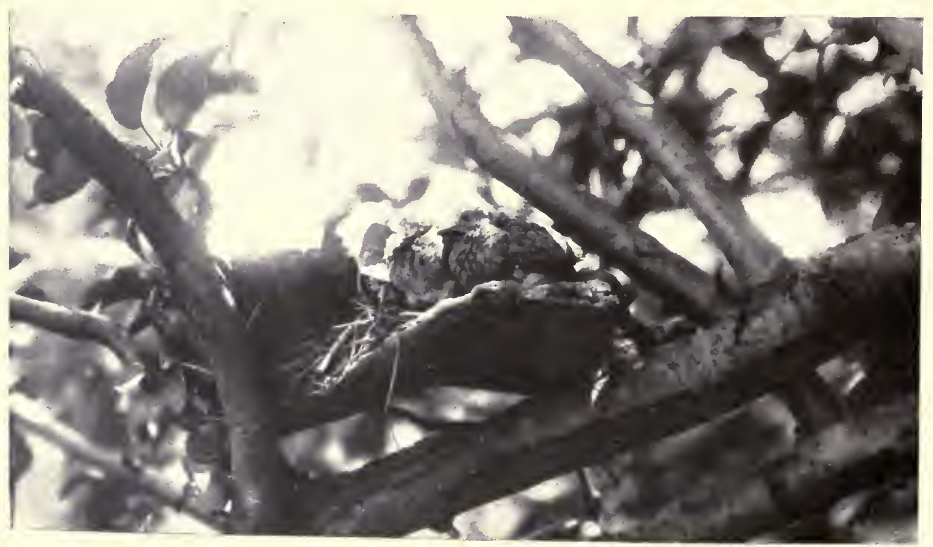

YOLNG DOVES OF APPLE-TREE 



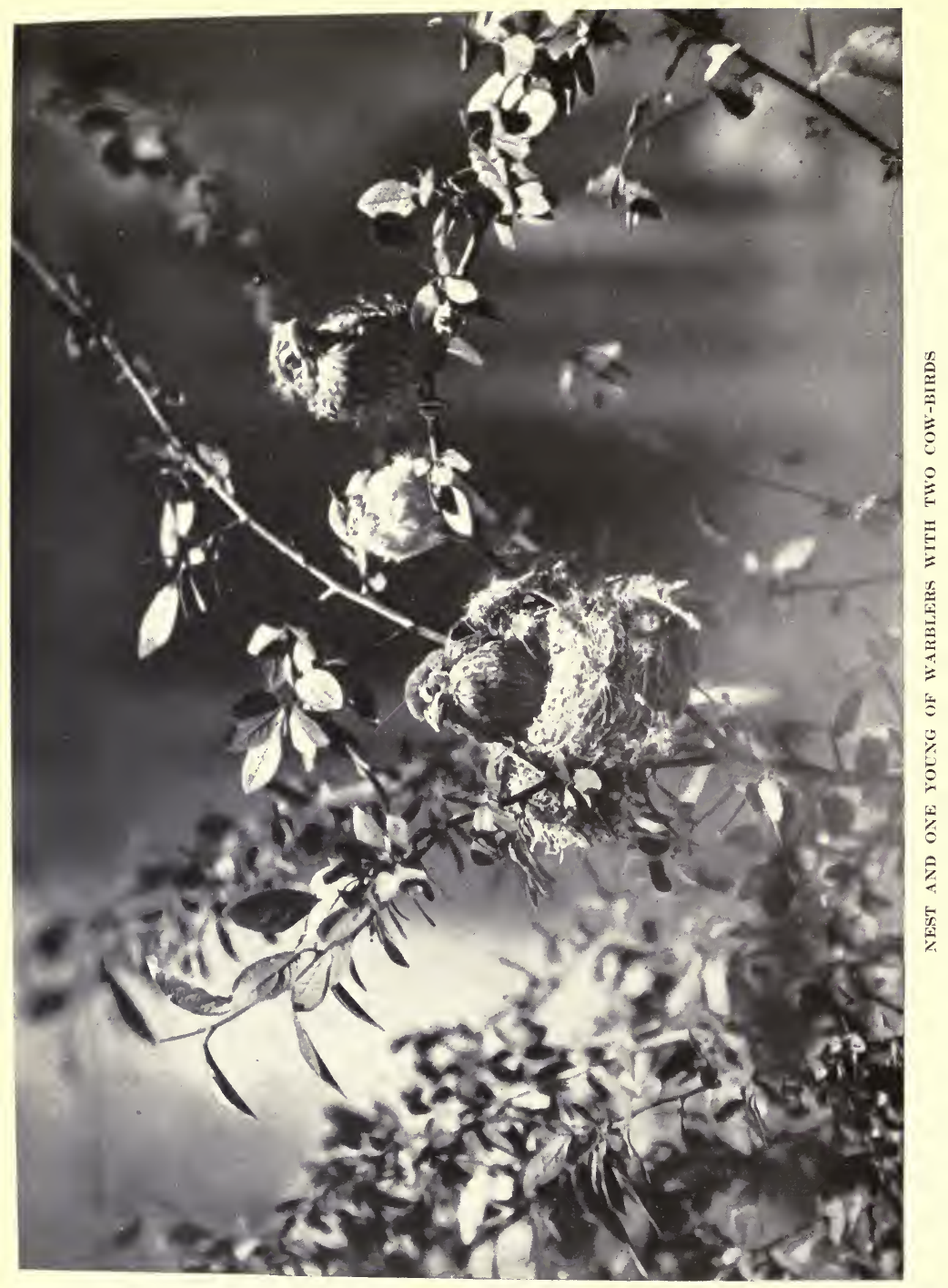




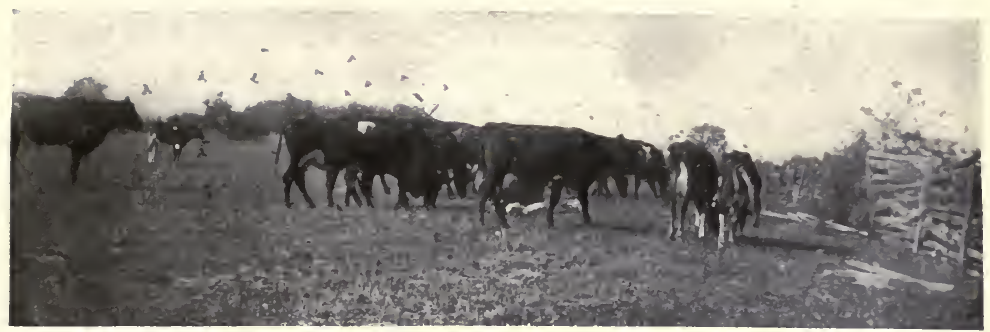

COWS AND THEIR FEATHERED NAMESAKES

\section{CHAPTER XX}

The Cow-bird: Molóthrus Áter

\section{IN THE PASTURES}

The sky was cloudless, the air was still. The dust lay thick on the country road. There were so many cicadas revelling in the drowsy heat and so many thirsty tree-toads calling for rain that it was as if one cicada and one tree-toad travelled with you, singing all the way. To the north lay fields of velvet-green where clover quickly sprang to cover the brown stems of the lately mown crop; dull tan where the timothy that now packed swelling barns had grown; gold stubble thickly dotted with the sheaves of garnered wheat; waving blue-green seas of unripened oats and the jade-coloured blades of growing corn.

Above the shorn fields the Larks flung down an interrogatory, "Spring o' the year?" as if they feared to state for fact a matter which might be open to question; for the season had been peculiar. Winter had lingered late. Then the spring rains began, cold and prolonged so that the leaves had been unusually slow in 


\section{FRIENDS IN FEATHERS}

opening while the birds had been forced to build low for shelter and later than ever before. Half these Larks had lost their belated broods in the garnering of the harvest and now they hung disconsolate above the shorn fields uttering querulous cries. Beneath them restless Shrikes gathered grasshoppers for halffledged broods. On the cross-rails the Song Sparrows piped bravely; from fence-corner saplings the Goldfinches questioned of every passer: "See me?"

To the south a sinuous line of giant sycamore, tulip, ash, maple and elm trees and the lapping purl of water marked the river near at hand, while the rattle of my Kingfishers and the splash of wallowing carp told the story of affairs of importance going on there as well as in the fields. Though it was mid-afternoon the prickly heat held unabating. The patch of red backs under the oak at Stanley's line fence meant that the herd had been driven from grazing, and bunched together, were lazily chewing their cuds and fighting flies. A flock of Cow-birds circled over and around them, snatching up insects their stamping feet drove from the grass or boldly foraging on their glossy backs.

Patience picked his way slowly while each foot fell with a soft, rhythmic pat that raised a small cloud of dust. The lines swung loosely from iny fingers as I sat on the edge of the seat and with roving eyes searched for "studies" from my Vultures hanging a mere speck in the sky above the Limberlost, to the hare scudding across the stubble or the winnowing of grasses that told of a snake sliding to the river.

At Stanley's Bend, Patience neighed sharply, pricked up his ears and broke into a swinging trot. The beast found intelligence and voice to show its anxiety to reach Bob; for Bob meant to him rest, shade, water, grass and Gypsy, with whom to make friends. And to me Bob meant the best person of all to whom to appeal 


\section{THE COW-BIRD}

for help, for "the birds know when the friend they love is nigh," and despite the deafening explosions of the gas-engine, the steady rumble of the balance-wheel, the creaking of the turning-table, the rattling rod-lines, the constant wash of the streams of crude oil that poured into the big black tanks, and the sharp metallic click of the valves as it gushed through the pipe-lines, the birds clustered around Bob until there were half a dozen there to every one on any other lease beside the river.

Paradise on the Wabash meant Bob's lease to me. I always stopped when passing for almost every day there was some wonder in store for me. The birds trusted Bob, as men trusted him, were unafraid as women were unafraid, and loved him as little children everywhere loved him. Patience left the road, crossed the grass to the tree he liked best and stood lipping the bark or watching down the path. I lay back and closed my aching eyes. The horse neighed sharply. There was a clear whistle and the bark of a dog in answer; a second later the pointer leaped the fence and came dashing down the path to touch noses with her friend. Then a man's head came to light among the bushes, his shoulders lifted above the bank; with a spring to equal the dog's he cleared the fence and came hurrying to the carriage.

As I watched him a warm wave of gratitude swept my heart. Bob always had understood, while there were so very few others who had. I had found such various people in my work. Of the land-owners of my territory many had opened their gates, laid down their fences, and given me freedom to go wherever my subjects called me. Some had left the plow and harvesting to assist me. Some had merely tolerated me, allowing me to shift for myself, others had closed their premises against me, yet others had charged me an enormous price for driving down a lane they used every day themselves.

But the oil-men always had been different. Whether I came 


\section{FRIENDS IN FEATIIERS}

in contact with a millionaire lease-owner or a ditcher in a trench, the mere fact that I was a woman, trying to do something at which they could help, had been sufficient. Some of them liad understood my work and some had not, but in no single instance had one of them ever failed to do anything in his power or to show me royal courtesy, while of them all Bob was king.

Without a word of salutation or apparent notice he walked straight to the small black and began knotting the hitching strap around the tree. As his hands moved a big diamond gleamed in the light. I knew Bob, but you never could tell about an oilman if you did not. An elegantly dressed individual might be a promoter with capital so nearly atmospheric that he lacked the price of his dinner, while a begrimed creature in jumpers and sweater might be a capitalist whose automobile waited in the stubble of the adjoining field while he inspected his holdings.

"Is there something for me?" I asked.

"There is," replied Bob.

He lifted the camera, picked up the tripod, ordered Gypsy to remain with the rig, then led the way down the path, through the boiler house, where the exhaust pipe "uttered deafening shrieks and the ground trembled with the throbbing of the big black monster, past his brooding Quail and Wood Robin, past his Blue Finch and Song Sparrow down to the nest of his Blackmasked Warbler.

"But I thought we agreed not to disturb her until she had brooded at least a week," I objected.

"Look!" said Bob, and kneeling, he bent back the wild plum bushes bringing to light the daintiest of little grassy, mosscovered cups. It contained only two of the beautiful Warbler eggs that had been in it the day before, and two big eggs with a white ground finely dotted with purple.

"What does it mean?" questioned Bob in rank disgust. 



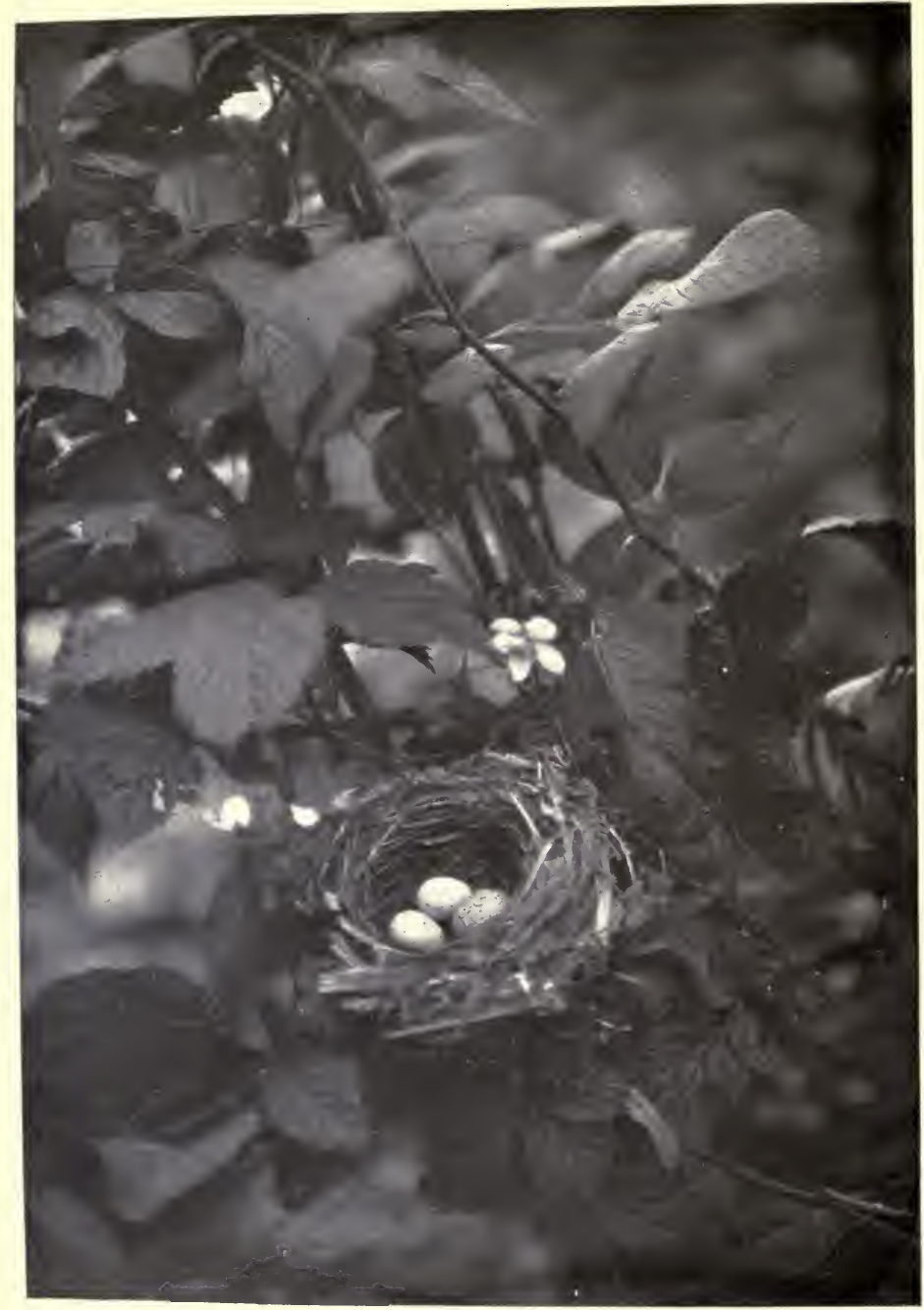




\section{THE COW-BIRD}

"Cow-birds," I answered. "When did you first notice this?" "Early this morning," replied Bob. "I heard the Warbler" fretting and went to see if a snakeor squirrel were bothering them. Two of their eggs were gone and those two big speckled things in their place. Make your study quickly if you want one, for I am going to smash them."

"Oh, no, you're not, Bob," I pleaded. "I wouldn't have you touch that nest for a farm. Those Warblers have just begun brooding and the Cow-birds have disturbed them all they will endure already. We will slip away quietly while you guard that nest as you never before guarded one. It is most uncommon for a Cow-bird to leave two eggs in a nest, so if they hatch, with those tiny Warblers, why then, we shall have a picture worth talking about."'

"But will the Warbler brood on them?" protested Bob.

"Hasn't she been on them all day?"

"All day," growled Bob, "and nothing but waiting for you ever kept me from pitching them out. I don't see how a bird almost as big as a Blackbird ever laid in that tiny nest, and what became of the Warbler eggs?"

"The Cow-bird ate them," I answered. "She disposed of one each time she deposited one, though how she managed to drop an egg in that nest without breaking the Warbler's is a mystery."

"I can easily break hers, right now," volunteered Bob, with that twinkle in his eye in response to which his discerning mother named him Bob Burdette.

"But you never will, Bob," I coaxed. "What you will do is to stand guard and make sure they hatch, and in the meantime find me the other Cow-bird eggs. She will lay two more, possibly three."

"What!" cried Bob.

"I said you would find me the remainder of her eggs. We 


\section{FRIENDS IN FEATHERS}

won't touch these, to make their hatching doubly sure, but we'll make our studies from the others.'

"Well, wouldn't that freeze you?" marvelled Bob, mopping perspilation. "I'm going to do it!"

"Good boy!" I applauded." "I know you don't very well like the job, but this is our chance for something really rare. The Cow-bird will come back to-morrow, at the same time she did this morning, and select the nest of some deep builder, so if you are on the lookout you are almost sure of seeing her."

The following morning Boh sent me word that the Cow-bird had imposed an egg on his Vireo: to come quickly if I wanted a study of it. I knew exactly what that meant. Bob uncovered in front of his Vireo nest. The little mother Vireo was so dainty, so delicate, so exquisitely coloured! Her beak was elegantly shaped, her back pale gray, her breast white, her ruby eyes so wise and so trustful, while her confidence in Bob, who passed close by her many times every day, was implicit.

Of the dozens of nests Bob had located, there was not one so exquisite as this Vireo's, for at the branching of two elm twigs, no higher than my head, she had built a pendent cup lashed to the limbs with bits of string and hair, wound securely round and round and even carried to near-by limbs. When it was solidly timbered, securely fastened and softly lined, to Bob and to me, who had watched its, progress, it seemed complete, but the little birdmother, with exactly the same loving impulse that is in the breast of a human mother when she adds lace and ribbon to her baby's cradle, set about gathering heary, rough, snow-white cobwebs and festooning them over the outside until the nest appeared as if dipped in ocean foam. She stuck through these webs a number of fantastically shaped little dried, brown, empty lastyear's seed-pods, as a finishing touch, then Bob took off his hat.

He said she was a lady so no gentleman would stand 268 


\section{THE COW-BIRD}

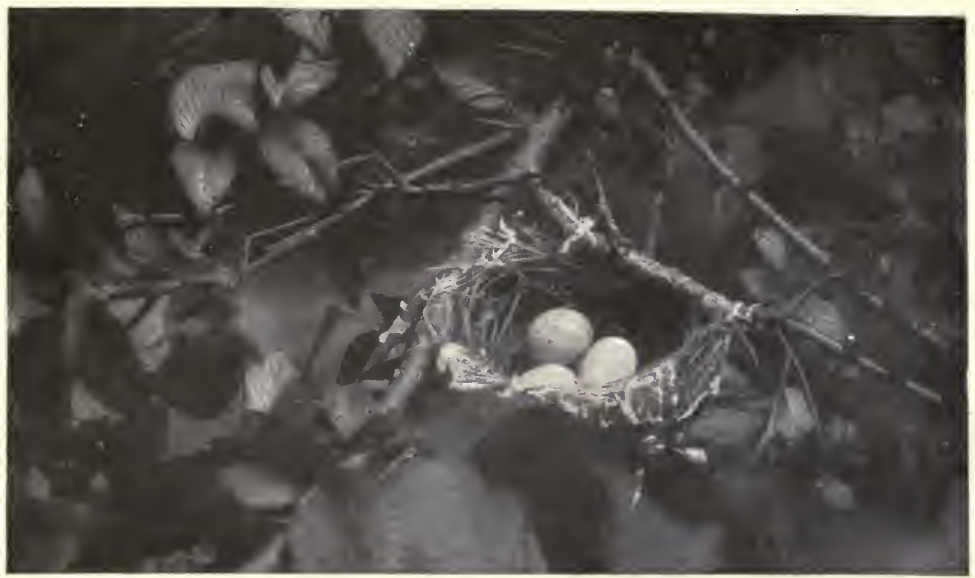

NEST OF VIREO CONTAINING TWO EGgS OF THE BUILdER AND ONE OF THE COW-BIRD

covered before her. He fairly worshipped the delicately coloured, jewel-eyed little pair and their exquisite cradle. Concerning them he was squarely on the ground of Nuttall, who said that, "wantonly to destroy these delightful aids to sentimental happiness ought to be viewed not only as an act of barbarity, but almost as sacrilege." Knowing what the destruction of a single Vireo egg meant to Bob, I went with all possible haste.

He was angrier even than I had feared, for the Cow-bird had eaten one Vireo egg and in depositing her own, cracked another. He had a little bowl-shaped paddle whittled out and ready, and on my advice scooped out the broken egg, lest it soil the contents of the nest in bending down the limb. We tied the branch securely so in a short time the two Vireo eggs and the big speckled one were on record. Scarcely had the shutter clicked when Bob 


\section{FRIENDS IN FEATHERS}

scooped ont the Cow-bird egg, dropped it on the ground and vindictively set his heel on it. I shuddered to think of the picture he was spoiling by not allowing that egg to hatch, but there was no use in asking him to leave it. There are times when Bob can say no; he had reached his limit when he left two Cow-bird eggs in the Warbler's nest.

"I'm glad that's over," said Bob, drawing a long breath. "I'll not stand having this little gray soul pestered again. If that Cow-bird comes here to-morrow I'll take my shot-gun and blow her to atoms."

In a few minutes the Vireo was on the edge of her nest, peeping inquiringly into it to see what had happened next. It really seemed as if she ruffled her feathers with satisfaction as she settled to brood on her two eggs.

The following morning, Bob kept his word about standing guard. He did not see the Cow-bird; but risiting his line of nests down the bank, when he thought all danger to the Vireo was over, found that this bird of brass had made a house-warming party all by herself and laid the first egg in the newly completed nest of a Song sparrow in a wild crab. While he awaited my arrival he noticed that the little father and mother Sparrow were working feverishly, and when we reached the nest a new floor was laid over the Cow-bird's egg, a Sparrow egg was deposited and the mother was brooding. That made four eggs for the Cowbird, so we figured that it would be the last, but the morning after Bob saw hel sneaking up the opposite river-bank with such elaborate caution it made her conspicuous.

She entered a thicket of wild rose and blackberry that contained no nest of which we knew, so he did not follow her. But wonder as to what she could have been doing there kept filling his mind, so he stepped into his boat and started across the river, in time to see her leaving the thicket in what appeared to be a 


\section{THE . COW-BIRD}

frenzy of excitement, so Bob decided that she had found a place to deposit her last egg and was rejoicing over the successful placing of her family.

He entered the bushes locating the nest of an Indigo Finch that he had not suspected was there. There were two of the delicate opalescent eggs of the Finch with the last egg of the Cow-bird, still warm to the touch. Again there was a hurry call. The study was beautiful. Bob unceremoniously dumped that egg also.

He heroically stood guard at the Warbler's nest and every few days we speculated as to what would happen there. Suppose all four of the eggs hatched. Would those dainty little Warblers be able to supply food for the Cow-birds and their own babies also? Would they feed their own and starve the strangers? Or would the beaks that could open widest and lift highest get all the food and the Warbler babies be trampled underfoot and die of hunger?

These questions soon were settled. All four of the eggs hatched, and although the Warbler babies should have been out first, we were amazed to see the Cow-birds emerge the same day, thereby clearly proving that they required several days' shorter incubation than the young among which they. were placed. The Cow-birds were three times the size of the Warblers in the beginning so they filled the nest. They crowded from the first. Scarcely was their down dry until they lifted sturdy big heads, opened cavernous mouths and the clamour for food began.

The tiny specks of bugs and worms that the Warblers were able to collect made small impression on their ravenous appetites. All day their heads were up, their mouths wide open. All day those little Warbler parents darted hither and thither, nervously searching for food to satisfy the greed of the foster children thrust so unceremoniously upon them. If their own succeeded in 


\section{FRIENDS IN FEATHERS}

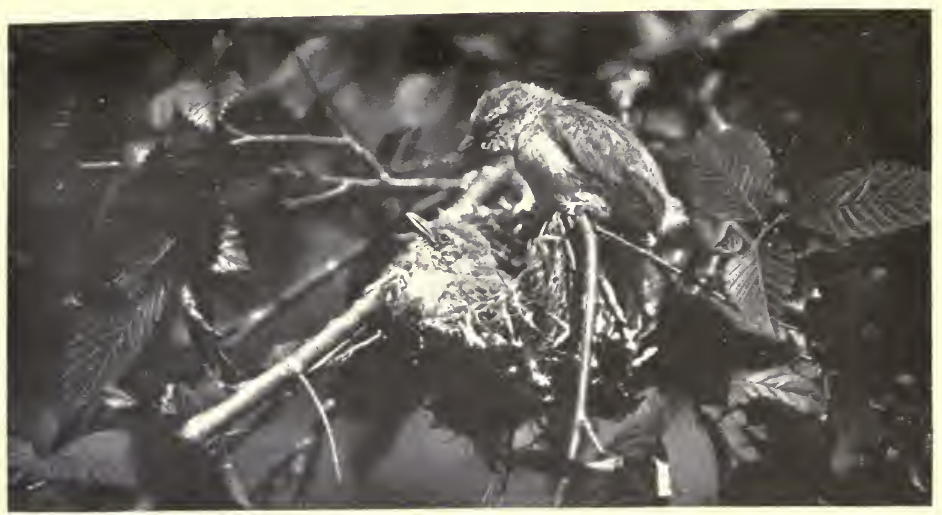

THE PAIR OF YOCNG VIREOS

securing a tiny morsel, really it was by accident, for they were so buried from sight and their feeble cries so drowned in the lusty clamour of the Cow-birds, that their end seemed apparent from the first. The smallest Warbler had no chance at all for in a few days Bob lifted him from the nest with my hat-pin, dead and trampled flat. I am afraid he "said things" when he did it. The beak of the remaining Warbler did not reach the butts of the Cow-birds' wings when he raised his wobbly little head to join his voice in the hunger-cry which went on all day, but some way he got barely enough to keep him alive.

The old Warblers seemed to feel that the continual cries from their brood were an imputation on their housekeeping, for they raced around pitifully, taking time neither to bathe nor eat enough themselves. Soon they were mere shadows. But day by day the Cow-birds waxed fatter and fatter while their cries grew more vociferous. Day by day the Warblers grew thinner. 


\section{THE COW-BIRD}

The baby's crop hollowed until it was drawn from sight, his eyes sank deeper and he grew more patient.

Bob's only relief was to watch his Vireos thrive. There being but two of them they were unusually well fed and grew to remarkable size and beauty. Every time he approached the nest the proud little father came turning somersaults through the air and inquiring with true pulpit oratory, "Do you see it?" "Do you hear me?" "Do you believe it?" while Bob with bared head and worshipful eyes said that he did. One day he found them

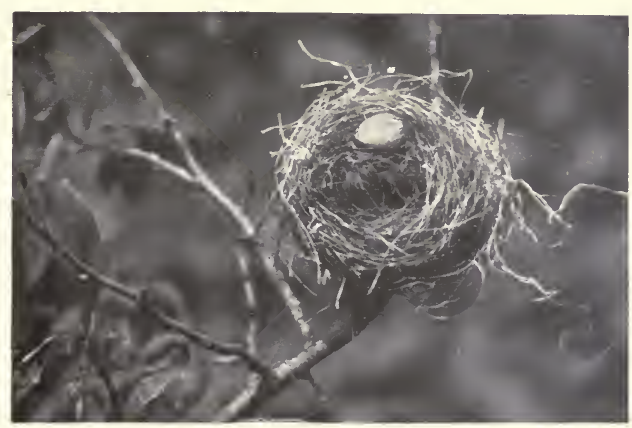

INVERTED NEST OF SONG SPARROW, SHOWING WALLED-IN EGG OF COW-BIRD

on the edge of the nest and sent for me to hurry, for he not only wanted a picture of them, but when they went it was time for the Warbler's queer brood to go also.

I arrived in time to secure a study of them, but soon they were gone. It was not until three days later that Bob found one of the Cow-birds on a limb, the other on the edge of the nest, and both of them so stuffed that by no possibility could they point their beaks straight forward over their swollen crops. The Warbler was fully feathered. There was not a trace of down on him, and 


\section{FRIENDS IN FEATHERS}

by every right he should have been the first to leave the nest; but he crouched down as if enjoying his first comfortable breathing-space, and clung to the nest as if he could not move. His crop and eyes were sunken, his beak and feet pale, his throat anything but the bright, healthy colour it should have been. Starvation was written all over him. There seemed to be nothing of him but a little bunch of bones and abnormally developed feathers. His plumage almost curled.

The largest Cow-bird climbed to the edge of the nest and sat there while the other stayed on the limb. I tenderly lifted the Warbler and set him between them to contrast their size and repletion with his condition. They never attempted to fly, but opened wide beaks and raised cries for more food, though where they were to put it one could not see. Bob said to them: "You little boogers! I know what you'd get if I were engineering this." I made several exposures then carefully put the Warbler back into the nest. where he remained all day, the Cow-birds staying in the samebush.

Then came the baby Warbler's picnic. The old ones alighted on the nest first when they came with food and if he were ready he got a good share before the rociferous cries of the Cowbirds ealled them away. The following day he had so improved that he could move in the nest while the Cow-birds, fat and sleepy-eyed, flew to a near-by walnut shrub, where I made a last picture of them. Next day I could not find them and when I remarked that they seemed young to have joined a flock of their kind, Bob looked so peculiar that I lost no time searching.

"Where do these things belong?" he asked as we gathered up my paraphernalia from the latest trip. "Are they protected?"

"They belong to the Blackbird family and they are," I answered. "The law makes two classes, wild and game birds. The section referring to unprotected birds reads: 'House Sparrows, Crows, Hawks, and other birds of prey.,", 


\section{THE COW-BIRD}

"Well, if Cow-birds are not birds of prey, I'd like to know what you'd call them," said Bob. "Have you figured it?"

"I do not know how many there are in the Stanley flock," I answered; "but the other day I counted over two hundred at Shimp's. It's fair to presume that half of them are females. Now here is one female that we know in one season has killed three Masked Warblers, two Vireos and one Blue Finch. If each female of her flock has equalled her record that makes six hundred of our most harmless, inoffensive, dainty, beautiful little songsters wiped out while if all Cow-birds average four eggs apiece there are four hundred of them instead. And Cow-birds are ugly, their rasping 'Cluck-see-ee!' is not song; instead of hunting for insects that need to be exterminated they sit on the back of a cow eating flies from a scratch; why sling-shots and the millinery trade are innocent compared with them! They should be exterminated!"

Since that summer not a Cow-bird flutters over Stanley's sleek herd. There are none at Aspy's adjoining, nor down the river far below Shimp's, so Bob's birds raise no foster nestlings.

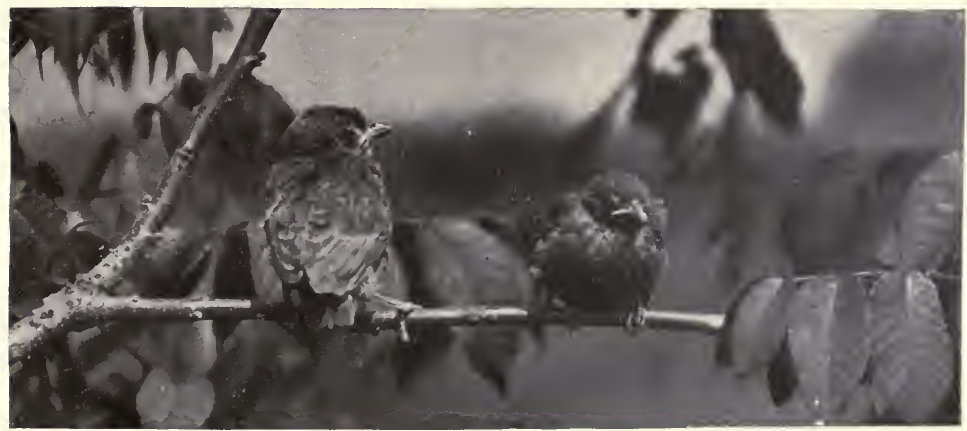

PAIR OF YOUNG COW-BIRDS 
The Sand-piper pipes all day on the sand, The Corn-eracker cracks his corn on the land, The Nut-hatch hatches in hollow nut trees, The Bee-bird is busy all day catching bees, The Oven-bird bakes; while every one knows 'The Tailor-bird makes the other birds' clothes 'The Cow-bird is named, I'll explain to you now, Because he's forever tagging after a cow. 



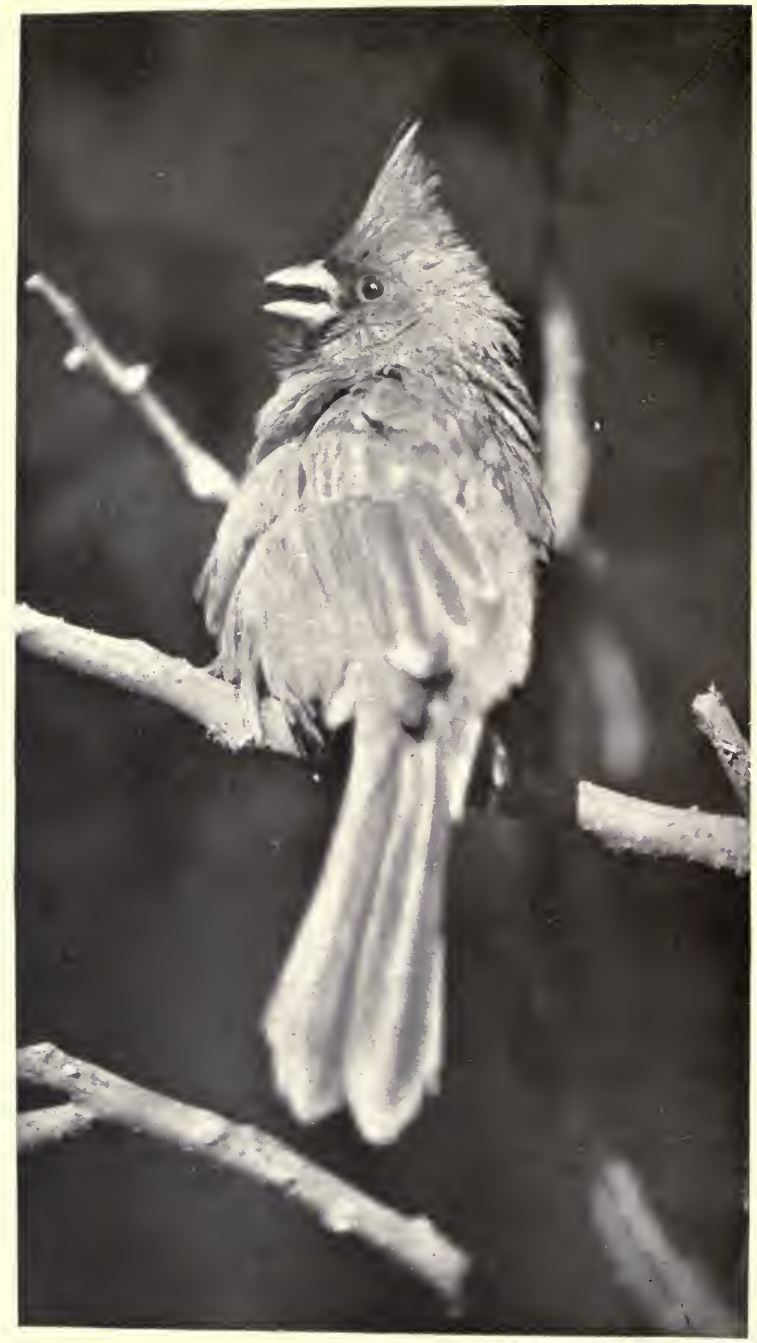




\section{CHAP'TER XXI}

\section{The Cardinal Grosbeak: Cardinalis C'ardinalis}

\section{IN SMALL TREES AND BUSHES}

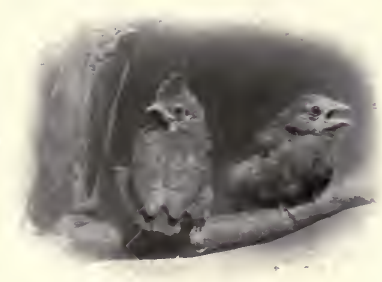

YOUNG CARDINALS

EARLY in my field experience with a camera, coming from the cast one day I found the body of a Cardinal Grosbeak lying in the dust at the entrance to the river bridge. I picked him up to keep passing horses from trampling his dead body. As I drove home with him lying on the seat beside me my feelings were outraged. The brightest bird of our Indiana ornithology, a fine musician, one frequently to be seen in our fields and forests throughout the winter, a seed-eater that seldom spoils fruit, enough of an insect exterminator to make his presence valuable anywhere - there he lay limp, his bright head never to lift again, his brave whistle never to enrich summer music and impoverish all other winter musicians-and for what? Merely to prove that some fiend with a gun could drop a shining mark.

Always I have been the devout worshipper, the true lover of this bird. By the time I reached the Cabin, "The Song of the Cardinal" had been sung in my heart. I immediately started gathering notes and searching for nests from which to make illustrations for the protest $\mathrm{I}$ had planned. Never having seen a 


\section{FRIENDS IN FEATHERS}

photograph of a Cardinal, either male or female, because of the disposition of the bird, I realized I would have to attempt a thing which no one else had accomplished at that time. As I scooped a deep grave in the orchard, laying the bird in and covering him with leaves before I packed in the earth, I rowed to make the name of any man who would kill a Cardinal, repulsive to humanity.

The first thing was to find nests. Bob, the man on our farm, and several oil-men were enlisted in the cause. During the three years following, studies were made of over a dozen Cardinal locations. I wanted a perfect, typical nest with a full chuteh of eggs, a series of the young: also grown hirds in every conceivable attitude that would display their heauty, their devotion to their mates, their fiery dispositions and their chosen environment.

I am qualified to speak of the Cardinal as of no other bird, having had three times the experience with him I have had with any other. I did not despair of securing the studies needed to illustrate the book I was planning, because when I was a child a pair of Cardinals had built a nest near the ground, on a flat cedar limb. not six feet from my father's front door. The remembrance that it had taken me only a few days so to become acquainted with them that I sat by the hour on the stoop, watehing with a child's broad sympathy every detail of their relations and home life, was my comfort now. If I could win a pair of Cardinals to trust me then, surely it could be done again, and the camera introduced also.

In the third year of my work, when material was rapidly shaping for the book, a suitable nest-picture was lacking. In a search for moth cocoons in the valley of the Wood Robin a delighted cry from my invahable assistant, Molly-Cotton, brought me quickly. She had found for me the typical nest, exactly what 



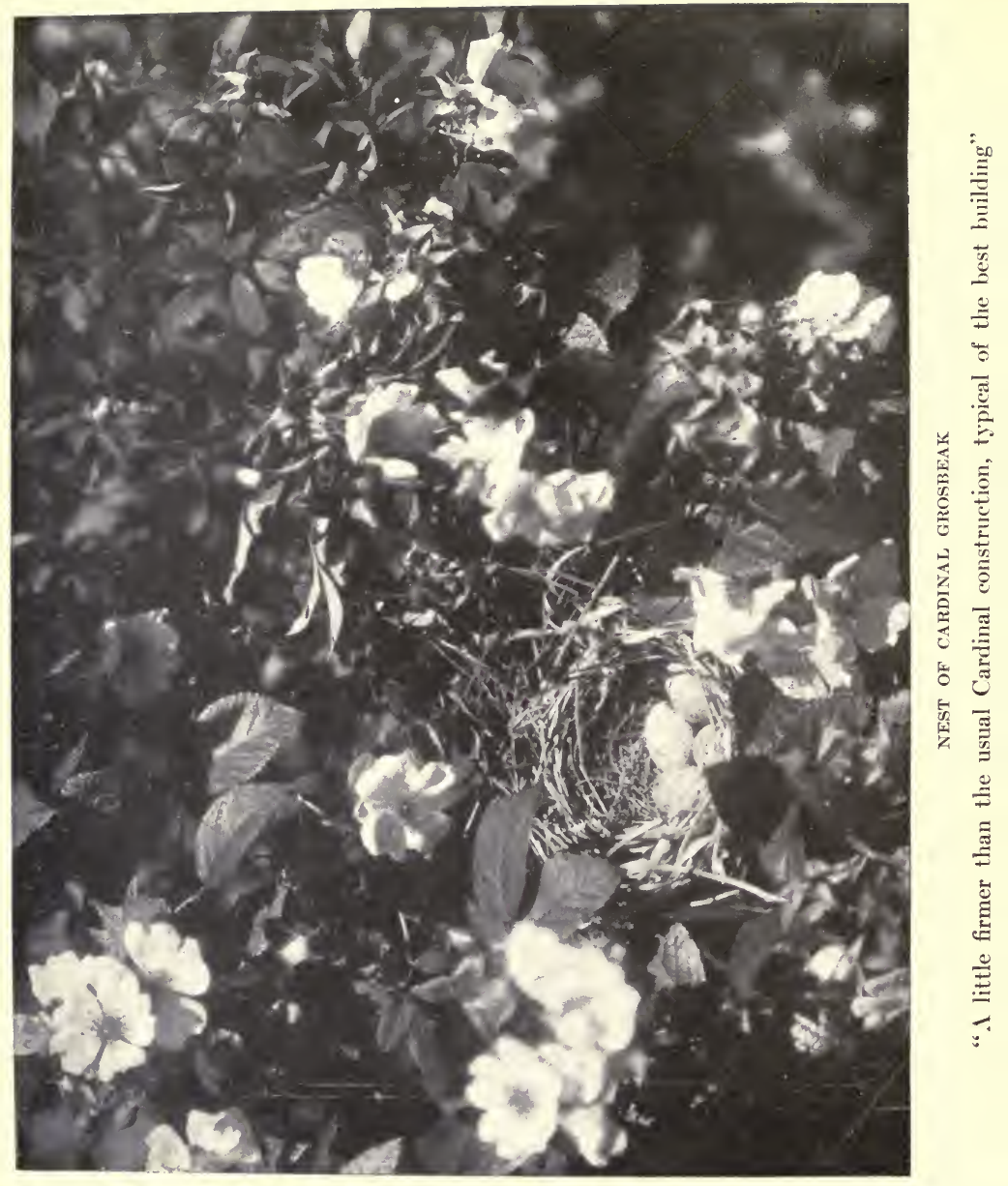




\section{THE CARDINAL GROSBEAK}

I wanted for my series. You should have seen her shining face when I told her so.

The nest was four feet from the ground, not far from the Wood Robin's location, on a brush heap overgrown and covered in a thick mat with wild roses, grape-vines and blackberry bushes. The roses were in full bloom, while their delicate blossoms were close over and around the brooding mother. The nest was a little firmer than the usual Cardinal construction, typical of the best building, the lining of dried grass thickly woven and cuppy, the four blue-white eggs mizzled and mottled all over with brownish and dark lavender specks, no two of them exactly the same colour, and one egg, undoubtedly the first, quite perceptibly larger than the others. That told the story of a young bird in her first brooding, where, as a pullet sometimes does, she had surpassed herself with her first egg. With the securing of that nest my series was complete, for I had sufficient material for every other illustration needed. Studies of more or less value had been made around almost every one of the nests located by others or myself.

I chose for the hero of my story a male Cardinal, undoubtedly a stray in Indiana, for he certainly was the big brilliant "redbird" of Kansas and Iowa. I could not carry him through the illustration-half a dozen different Cardinals had to be reproduced for that - but I photographed him several times alone, so that he dominated the work, while the others used did not appear so unlike him as to attract the attention of anyone reading for the story.

As described in the book, this bird really was "the biggest, reddest Redbird" ever seen in that locality. His home, in a thicket of sumac, on the bank of the Wabash River, was on the Brown farm northeast of the village of Ceylon. Cultivated fields came to the bank, enclosed by an old snake-fence; a few feet 


\section{FRIENDS IN FEATIIERS}

of grassy ground was covered by sumac, wild plum, red haw, thorn, spice brush, papaw and vines of every native variety; then the embankment sloped abruptly to the water which sparkled over clean pebbly shoals. Mercifully we were undisturbed. The location was farther from my home village or from Ceylon than boys playing at the river eared to walk; the water here was very shallow, so that bathing and fishing were impossible. I never left my carriage anywhere close the nest, but approached it always from the river, so that workers in the field would not see me and investigate.

IIe was not only the biggest and reddest, but his beard was the blackest and the longest - witness the reproductions-his crest flared the highest, his whistle was the mellowest and he was the tamest of all my Cardinal birds. It would interest no one to be told how many plates I spoiled on him; in three instances I pictured him at his level best, which paid for all failure, time and expense.

These pictures were secured by cutting off a living limb on which he was aceustomed to alight in a pause before he reached his nest, then substituting a dead branch in its place. He never seemed to know the difference, for soon it became a favourite resort with him. He liked to sit there to be sprinkled during a light shower. It was the finest place in the world to fluff and dry after his morning bath. No other spot was so to his liking for a sun-bath.

The camera was concealed in the thick leaves of a papaw bush a few fect away, a green strip was bound over the shining brass of the lens, the camera was covered carefully with leaves, then the exposures made with a big bulb and long hose.

A detailed story of all the time spent on these Cardinal nests would fill a larger book than this, but a few incidents may be 



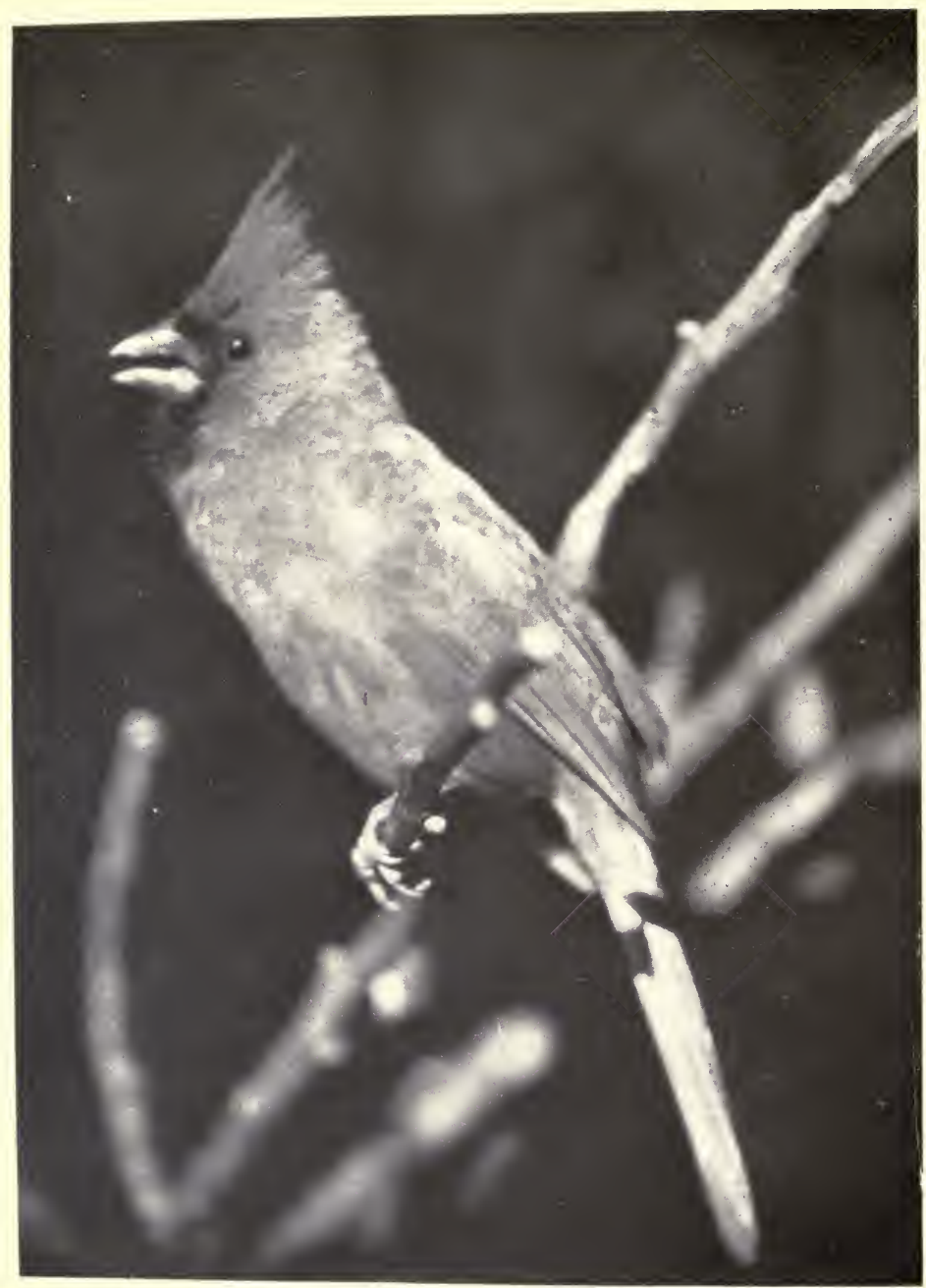

MALE CARDINAL SINGING

"I know of no other bird that, in the stress of mating-fever, rocks, trills, lifts his wings, turns his head and so displays his passion and his power" 


\section{'THE CARDINAL GROSBEAK}

interesting. There was no way to photograph a Cardinal without a nest to lure him. How then was I to bring the big bird, from the big egg I had found to account for him, up to his first mating? I was forced to send him south, but as Cardinals migrate, especially the young for their first winter, that was all right. I thought seriously of going to Florida to try my luck, but I was overwhelmingly busy. How I did want to reproduce that crimson bird on a waxy-green orange bough! There was a nest location from which I had made several good pictures, for the Cardinals had preëmpted the sumacs on this stretch of river-bank for years, so there was plenty of sumac setting. But how was a Cardinal ever to be found alone on something that would answer for a southern tree for the opening of my story?

Watering plants in my conservatory one day I scratched my wrist on the thorn of a lemon-tree. That solved my problem in a hurry. Before night the tub containing the tree was worked into the Cardinal's surroundings, covered with moss and grass, then the tree so arranged that a small limb replaced the perch on which both male and female alighted on entering the nest. The birds are accustomed to having all paths, save their trackless one of air, changed with every passing windstorm; it was a limb, green like the other, so it was used instead. Four exposures were made on the male bird there before that device was removed. Three of them were suitable to use, two were better than I hoped for, while one was unaccountably foreshortened so that it was a failure. After my success with the lemontree, which I thought so like an orange as to answer, that perch was changed almost every day to give a thread of continuity to my illustration.

A Cardinal is a strenuous lover, his attachment to his mate being unusually strong, his fighting capacity equal in force to his 


\section{FRIENDS IN FEATHERS}

affections. He shows no mercy on a rival and spares no atiention to his mate. He is a splendid musician and rastly proud of his vocal ability. I know of no other bird that, in the stress of mating-fever rocks, trills, lifts his wings, turns his head, and so displays his passion and his power. Is never before I found in him material for studies which were reproductions of character. Iet do the best I could, my likenesses of this vivid bird always seem pale and small to me when I think of the pictures he made there in the sumac, living out his life of joy and freedom.

All the studies one could wish of young could be secured around these nests as easily as those of any other birds, but Cardinal young are an especial temptation. There is lure in their deep hazel eyes, flaring crests, important carriage and their red-tinted feathering. A pair of them makes a picture difficult to surpass in attractiveness.

I have followed several pairs of birds throughout one season and made more or less complete series of them, but the Cardinal is the only bird I have followed season after season, through days and weeks of unceasing hard labour, and I have done it in the hope that what I might write and tell would serve for his protection. I think it has. His book: "The song of the Cardinal," the most emphatic plea I could make for him. has travelled wherever the English language is spoken, and been translated into three foreign tongues. In every state of the Lnion Mr. Edward Whitney has rendered his story before large Chautauqua audiences in the leading cities and towns. Every year now, sees him coming in increasing numbers.

He is our brightest, bravest bird. Not only are field and stream enriched by his summer music, but our winter woods during the gray days, in severe cold, resound with his cheery whistle, and, oh, how we need every winter singer! 


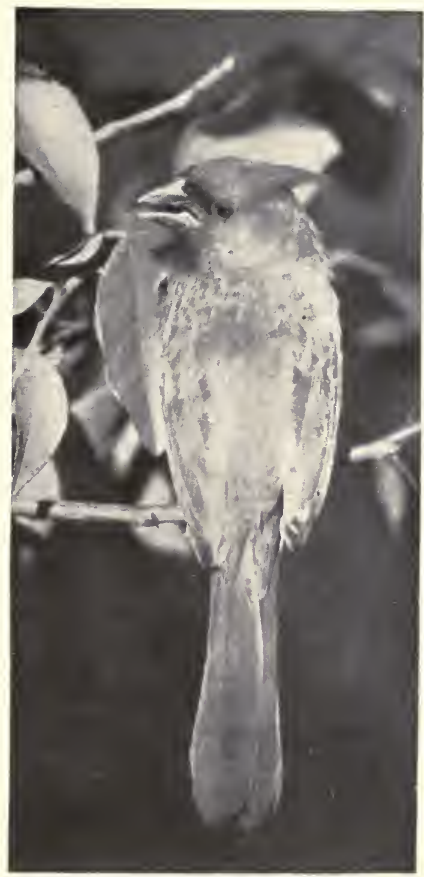

"And, oh, how we need every winter singer!" 
"What cheer!

What cheer!

That is the Cardinal Grosbeak's way,

With his sooty face and his coat so red.

('heer! cheer!

What cheer!

Oh, all the world shall be glad to hear!

And the nightingale

Shall fail

When I burst forth with my freedom song

So rich and strong!"’

-Thompson. 



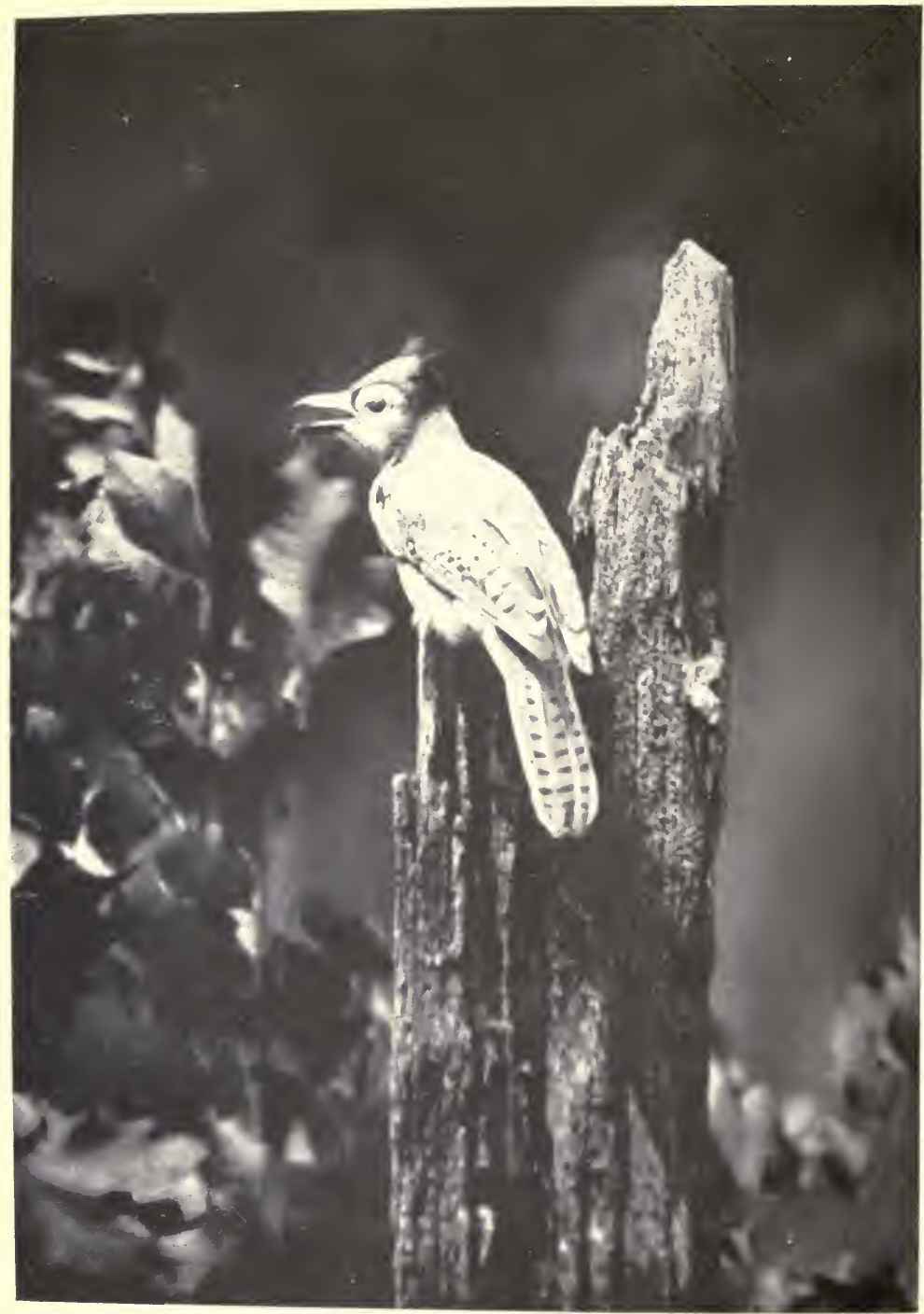




\title{
CHAP'TER XXII
}

\section{The Blue Jay: Cyanocitta Cristáta}

\author{
IN THE ORCHARD
}

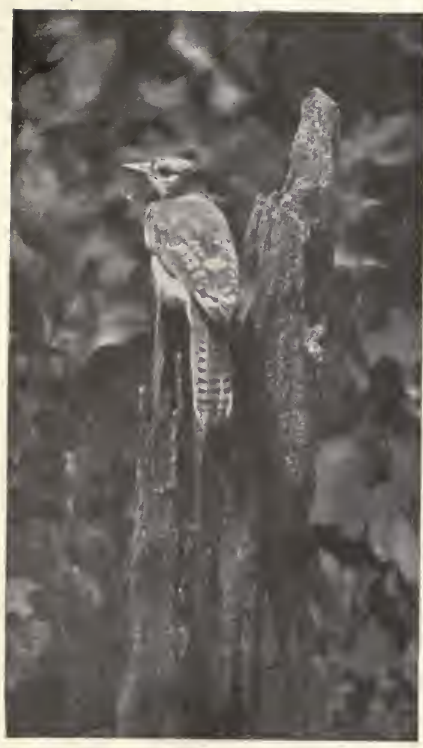

A Long-Time friend of mine told me that "if I were interested in such a blamed nuisance as a Jay Bird there was a nest in a grape-vine covered scrub elm in a fence-corner on the west side of the orchard." So I turned in at the lane, drove past the machinery sheds, past the garden where squares of radishes, onions, lettuce, poppies and phlox were surrounded by a hedge of gooseberry and currant bushes, past the milk yard, past the big red barn, and down the long lane which separated the orchard from a wheat field and led on to the creek. This world has no more beautiful spot than that orchard. The big trees were at their prime, there was a thick carpet of waving grass beneath them, an arch of blue with lazy floating clouds above, while around it was a lichen- and vine-covered old snake fence, most rails of which housed uncounted tenauts. 


\section{FRIENDS IN FEATHERS}

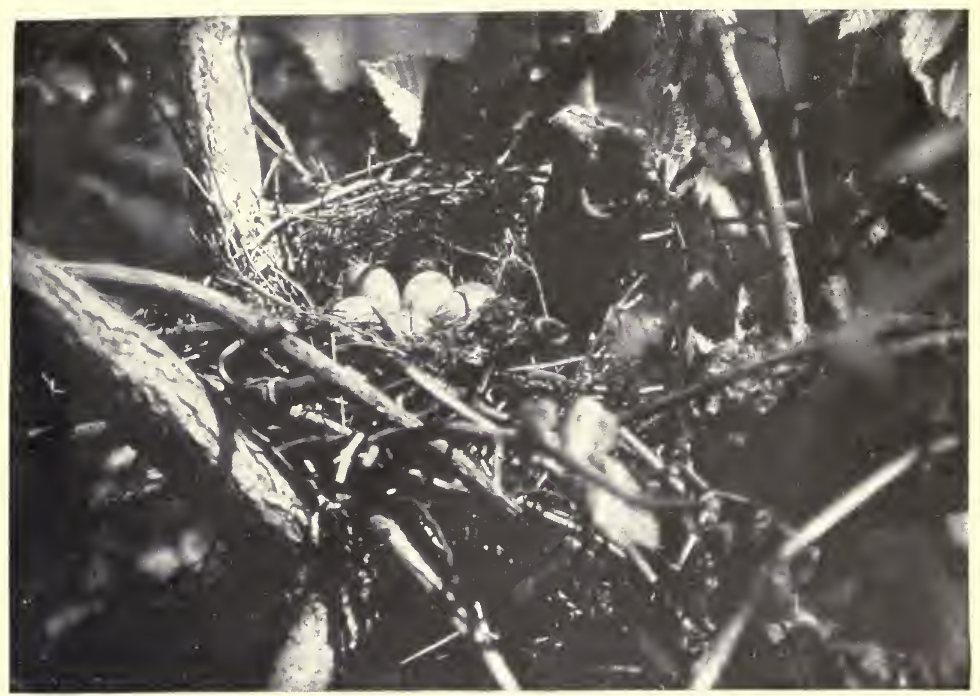

THE JAY NEST IN THE ELM

Sky-larks from the wheat fields hung over it, their notes of piercing sweetness ringing constantly; Song Sparrows were piping from the fence, while bees droned over beds of calamus in one corner or paid shorter visits to blue-eyed Marys and white violets sprinkled all along the west side, where they had the benefit of shade and moisture from the adjoining woods. The Jay could be heard long before he could be seen. He recognized the carriage as something new, so he sounded an alarm, until he put every bird of the orchard on guard by the time his fencecorner was located.

The Jays had set their nest on a limb of the elm which made a substantial foundation, so studies of it could be made from a 


\section{THE BLUE JAY}

step-ladder. All the material used was the colour of the bark of the tree, while the nest was very neat for Jays. It was shaded by masses of wild grape-vines and Mother Jay was serenely brooding when I found her. The first thing was to accustom the Jays to my presence in the orchard, then to try for studies of the gaudy brooding bird.

So I sat down under a rambo across the fence from the elm and studied Jay character. Before finishing with those birds I found that they had character in plenty, but of a kind scarcely compatible with the peace of other birds. Sooner than I expected, the racket Father Jay made at my intrusion ceased, no doubt because he was too busy protecting his mate from the Hawks of the woods to bother with me; so I moved closer.

I had work to concentrate my attention on the Jays, despite all a series of such well-known and characteristic birds would mean to me, for to the Lark's call and the Sparrow's lay were added the notes of the Killdeer down at the creek, the scream of Ganders busy guarding their feeding flocks, the gobble of the Turkey-cock from the dooryard, the boasting of the big Brahma Rooster over by the barn every time a Hen came out and announced that she had laid an egg, while June at her prime was oozing from all the earth, air and sky.

A sound which caught and fastened my attention on the Jays was made by the male suddenly screaming, "D'jay! D'jay! D'jay!' and then giving almost the exact imitation of a Hawk's cry. Looking up I saw one of those big birds sweep from the woods across the orchard. Then the Jay paid the farmer his "keep," also in a measure atoned for his meanness to other birds; for at his warning every chick of the Yellow Dorking catching grasshoppers in the orchard ran for cover with never a cheep; 


\section{FRIENDS IN FEATHERS}

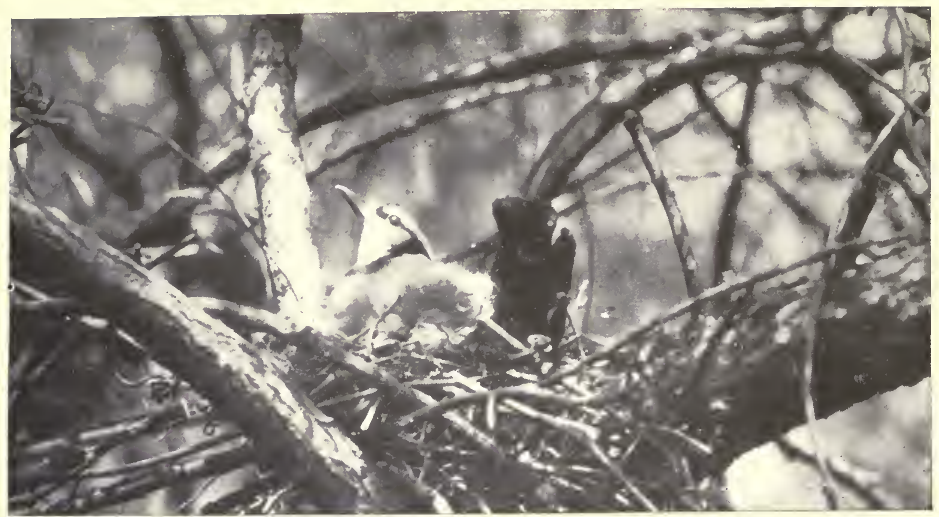

"A baby thrust its head throngh its mother's breast feathers laid it on the rough edge of the nest and went to sleep"

and where a bahel of bird-roices had commingled before that ery, not a sound was heard afterward. Even the Lark hurriedly dropped to earth to become lost in the wheat.

But Mother Jay bravely remained on her nest, so presently her mate came slipping between the trees and went to her to learn if she were all right. It did not seem possible that the strident rasp of his warning and the tender softly-modulated rejoicing in which he now indulged could have come from the throat of the same bird. His every action proclaimed that he had come to tell her how he loved her; that she need never have a fear while he was on guard. Surely that was what he told her, though to me it sounded like: "Chinkle-choo, tinkle, tankle, tunkle! Rinkle, rankle, runkle! Tee, chee, twee?" Then he flew to the top of the tallest tree of the orchard to stand guard again.

Gradually I moved up, until I stood where a tripod should be 296 


\section{THE BLUE JAY}

placed, but the brooding bird never flinched. Slowly and carefully I made my way back to the carriage and with my assistant brought up and placed a twelve-foot step-ladder, then mounted it with much caution, making a long wait on each step. The bird sat so securely I decided her eggs had quickened, so I climbed down, moved the ladder nearly under her branch, mounted again and cut away grape-vines and small twigs that would be out of focus. That blessed Jay Bird sat there while I used the clippers on a grape-leaf not four inches from her breast. Then I placed the ladder exactly right, but it was too low, so I added a mineralwater box, securing it with the hitching strap. Still it was too low, so I emptied my carrying case and set it on the box, then placed the camera on that. Then I focussed and made several studies of her. Throughout the whole proceeding, which was not

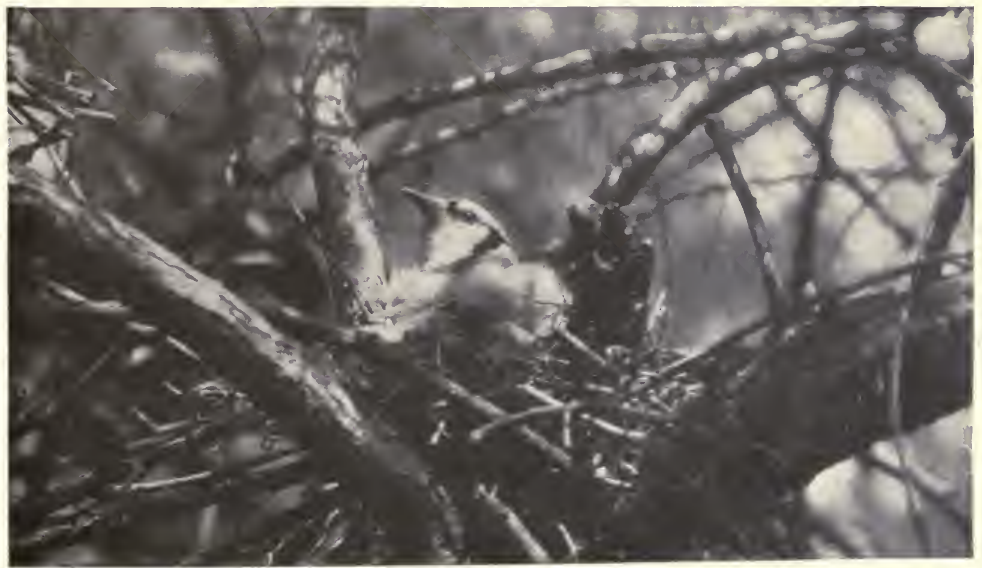

"The baby lifted its head, opened wide its yellow mouth and asked for food" 


\section{FRIENDS IN FEITHERS}

managed with my usual caution toward the last, when she proved so bold, Mother Jay sat, her beak pointed skyward and without giving any evidence of fear or indication of flight. Then, because in field work I never feel sure of my subject from one day to the following, I reproduced the nest with its five beautiful eggs before leaving.

When 1 went back early, a nestling had arrived ahead of me, which explained why its mother brooded so constantly the previous day. For several days I called on them securing some interesting study at each risit. Once while waiting with a set camera and long hose in the hope of picturing Father Jay feeding his mate or nestlings, a bareheaded, yellow-mouthed baby thrust its head from under its mother's breast, and using the hard rough edge of the nest for a pillow, went fast asleep. I gave the bulb one frantic grip, then hastened up the ladder to turn the plate-holder. I barely had it inserted when a wonderful thing happened. The baby lifted its head and opened wide its yellow mouth against the breast of its mother. For an instant my fingers flew so fast I was scarcely sure I had caught it. The shutter proved I had, so in my delight I called to my assistant: "Look here! Quick!"

"Take it!" he shouted. "Take it!"

"Well, do you suppose I stopped to call you to look before I did?" I questioned reproachfully. "I never have seen a picture like that made with a camera or drawn by an artist. I truly believe I have something perfectly new.",

"Smart Alec! Smart Alec! Smart Alec!" cried Father Jay, as he came winging into the elm with a worm in his beak, which seemed in no way to impede his utterance.

So to prove him a truthful bird I thrust another holder into the camera and photographed him as he fed one of his nestlings a worm while at the same time Mother Jay emptied a cloaca. 



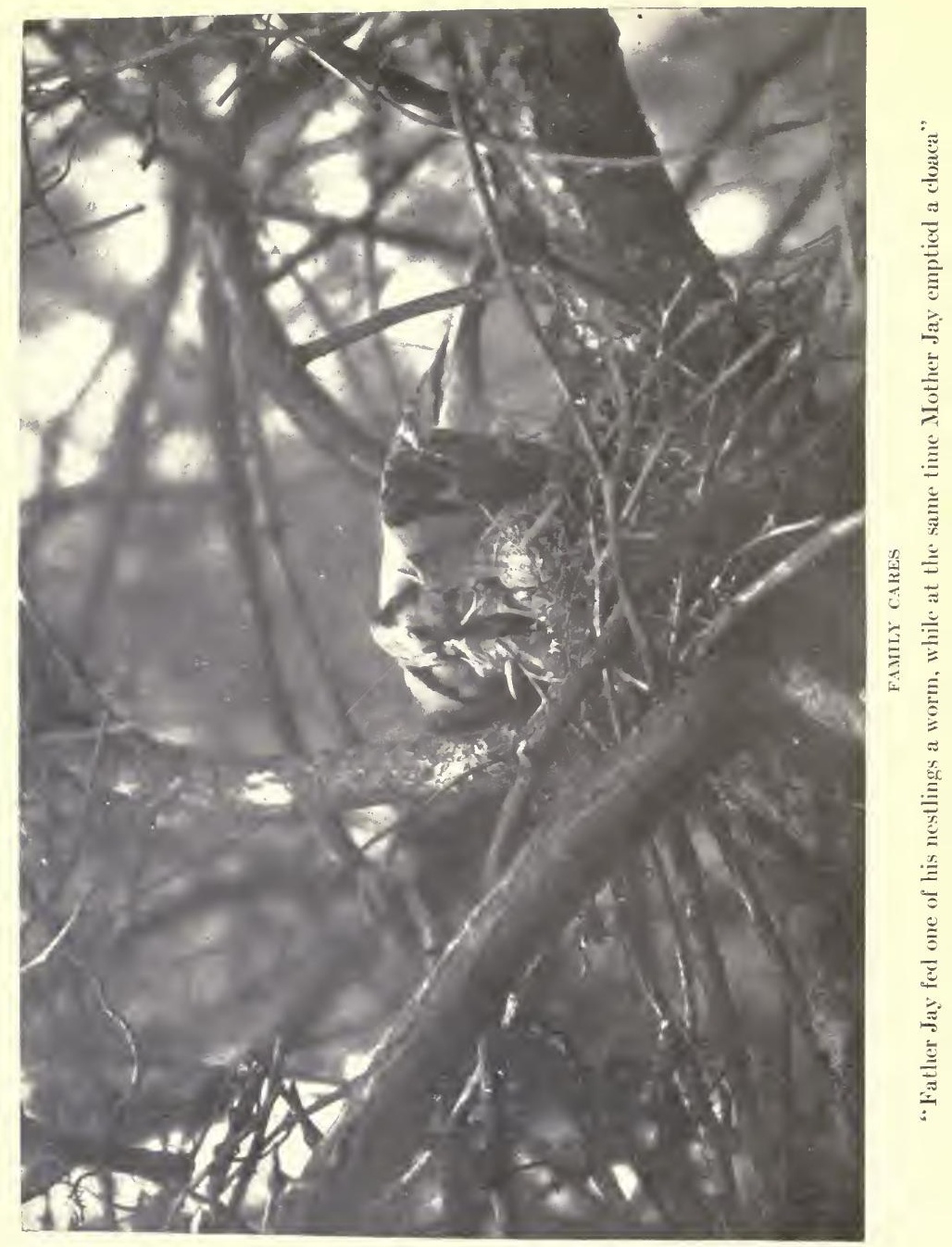




\section{THE BLUE JAY}

During the following days I studied those Jays. There was little new to tell. They did eat the eggs of other small birds, and the newly hatched young as well, they even tore up tiny nestlings to feed to their babies. They did impose on smaller birds, torment their equals, yet act the coward with larger ones. There seemed no evenness of temperament in them. It one minute they came slipping through the trees, cowards in hiding; the following, gaining a sudden access of courage, from the top bough of the tallest tree in the orchard, they screamed defiance to all creation, bird, beast and human.

The male truly was:

“Mr. Bluejay full o’ sass,

In them base-ball clothes o' his."

But he flew to his home base instead of sliding, for he kept his suit immaculate. The orchard was so clean and the creek so near he had no excuse to be otherwise, while he asked none, for twice and three times a day he went to the water to bathe and to dress every feather on him carefully, always ending by polishing his beak.

I wanted to make a true character-study of him aloneone that would index him without a label; one that would show him as he screamed Hawk-like when on guard. But I could see no way to photograph him away from his nest, while he was not the same bird close his cradle, when he felt weighted with family cares.

I never have secured a picture by giving it up, so I sat under a winesap in line with the rambo to study the situation closely. There I saw something. Blue Jay frequently went over in the wheat beside the fence to catch small worms and grasshoppers. 


\section{FRIENDS IN FEATIIERS}

Every time he came back from the west, he broke his long flight by perching an instant on a tall stump in another fence-corner sitrounded by a growth of hickory and sycamore sprouts.

I set up the camera, leaned two rails against the fence on each side of it, covered it with green leaves and at tached the long hose. The seheme worked perfectly. I took three pictures of the full-grown Jay, a rare one with swollen throat as he sereamed defiance, seemingly in answer to the ery of an old Gander down by the ereek; one with closed beak: and one of the female, all sharp and strong enough to enlarge beautifully.

These studies proved it quite true that most hirds select a route by which to come to and leave a nest. If you watch them you can nearly always diseover it. Sometimes the femaleand male approach from different sides, each coming and leaving by their own routes. Both these Jays entered their tree by way of the stump, coming from the west; and by way of one certain branch of the rambo when coming from the orchard. Many other birds follow this custom. The Cardinals I knew best each had a path eoming to and leaving the nest, from which they never varied unless some sound startled them. A pair of Baltimore Orioles I knew well both used the same route in approach and leaving.

On the morning the oldest Jay baby first investigated the apple-tree, I posed him, with his mates, on a maple limb and took their pictures. Some young birds are worse subjects while some are better, but I seldom have made a finer baby picture. Their colours were similar to their elders, not quite so strong as they would be after a first moulting, while their feather-markings were the same. Their beaks always were wide open, and how Father Jay worked! Every few minutes he came slipping into the elm to feed a nestling, and then left in a hurry to bring another lunch; but always he paused on a near-by tree and 



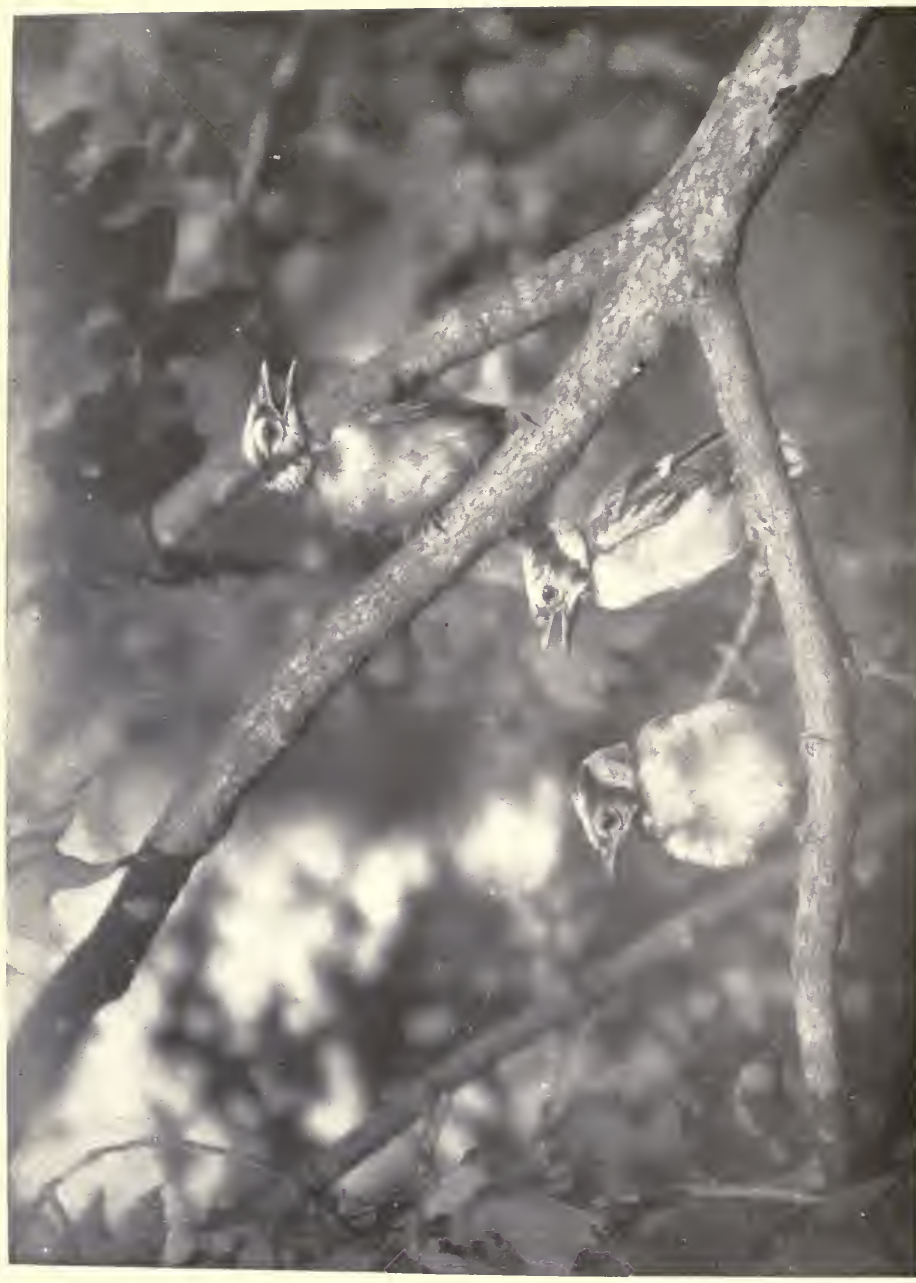

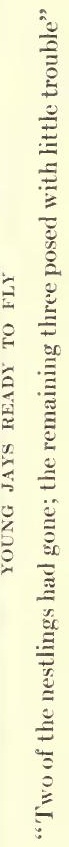




\section{THE BLUE JAY}

called back to Mother Jay: "Fill the kittle! Fill the kittle! Fill the tea-kittle."

My feelings concerning the Jay are varied. I admit all his bad traits, but there is in his favour the fact that he so perfectly imitates the cries of several birds of prey that he saves many of the woodland folk from Hawks; whether as many as he destroys, I have no way to determine, but I think so. He is forever guarding the woods, while every bird of field and forest knows his signals and heeds them, to that I certainly can testify; for lying in hiding, I repeatedly have seen birds take to cover at his warning when it required some time for me to discover what was coming; but always he was a true prophet, for something came, either a hunter, Hawk, Owl, Crow, squirrel, snake, or close houses, sometimes a hungry cat.

These alarm cries are not pleasant, but that the wood-folk heed them should prove that they appreciate and are grateful for them. He is a spot of brilliant colour around our homes in winter when birds are scarce, while his "D'jay, D'jay!" cry is a cheery and welcome sound, proving as it does that we are not altogether deserted. In courting he carries on a long, low conversation far down in his throat, while his tones are sweet and musical. Not only do Jays use this sweet throaty murmuring in pairs when courting, but throughout the season they congregate in small flocks to have a party.

There is one big maple on the banks of the Wabash, beneath which I have caught a few black bass, where the Jays for years have gathered at intervals for one of their tree parties. It least half a dozen collect in the tree perching close together. One begins to chatter, jabber, chuckle and murmur. Another joins him, then the whole company, then one continues alone, several more join in, and again the whole flock unite in a sweet, inquiring, throaty vocalizing that is music in which I delight. The Brown 


\section{FRIENDS IN FEATHERS}

Thrush chants exquisitely from a thorn opposite; the Oriole flings golden notes on wing; while the elear. strong whistle of the Cardinal carries bcautifully with the water; but the undertones of the Jays are a minor melody which fills in the pauses of these star performers with constant harmony.

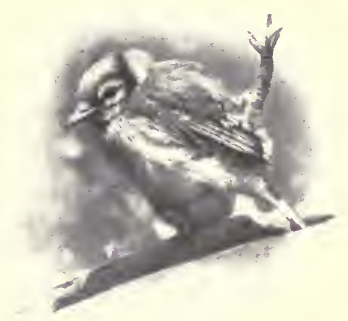

YOUNG JAY 



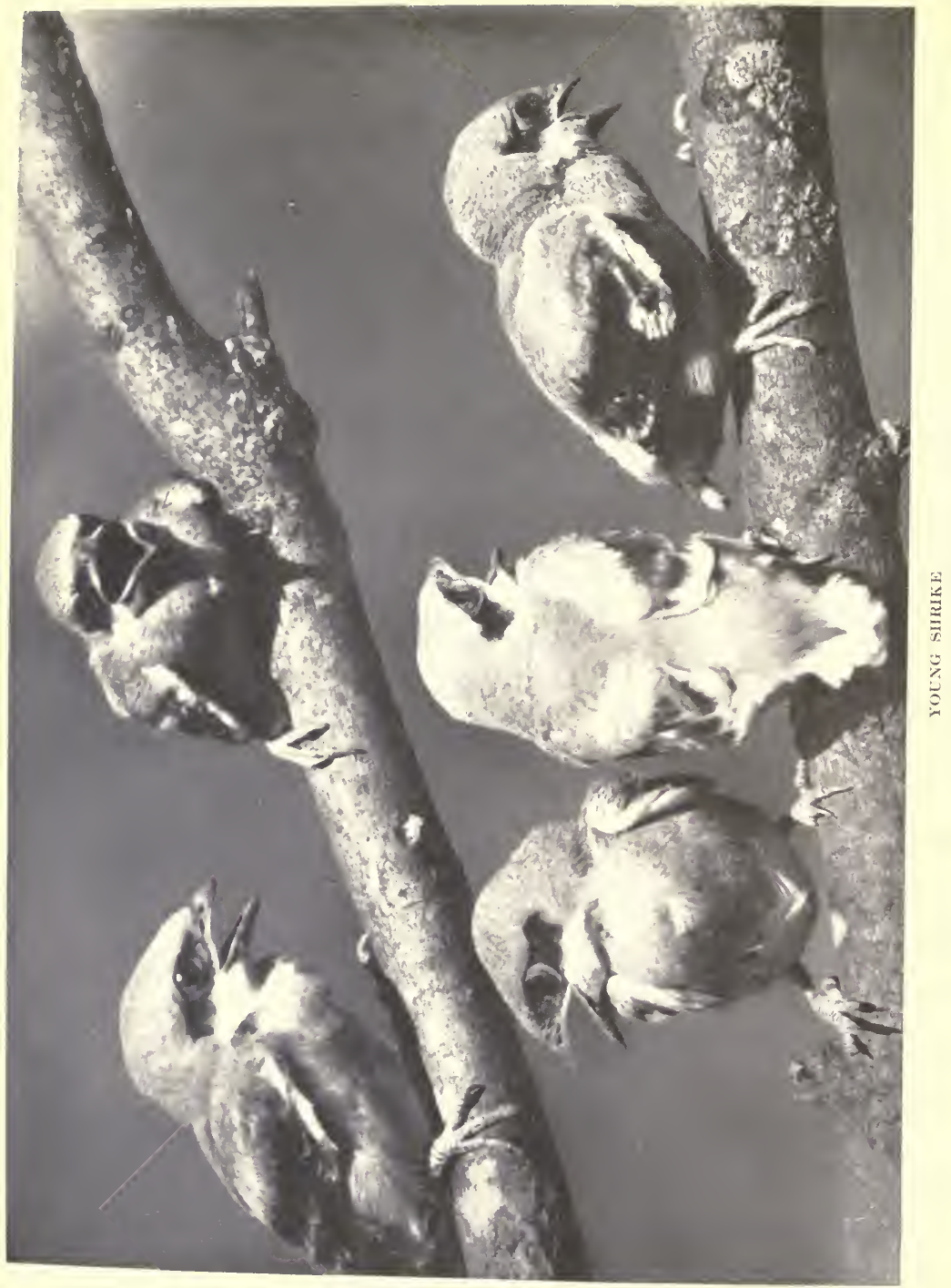




\section{CHAPTER XXIII \\ The Loggerhead Shrike: Lanius Ludoricáanus}

IN FIELD TREES

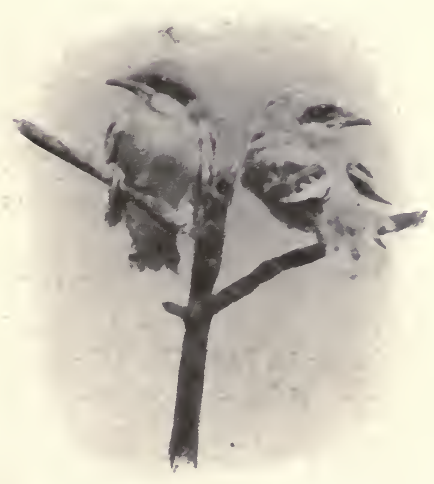
hood. He has studied them in half a dozen different states, so he knows them well. He was the manager of a large oil-lease lying on the Wabash River where it had a strip of thicket on one side and a heavy forest on the other. He held this position because of his love of the woods, for from Pennsylvania to Colorado he is familiar with all outdoors. When the machinery of his leases ran smoothly, Bob went out and searched the fields, riverbanks and woods for bird-nests. He located them in large numbers, then escorted me to them, often carrying heary cameras and ladders. More than this, when I was crowded with field 


\section{FRIENDS IN FEATHERS}

work he trained a pair of birds by setting up three sticks for a tripod, using a soap box for a camera, with an old coat for a focussing cloth, until by the time I reached them they were neither man-shy nor camera-shy. II leases were covered with Martin and Bluebird boxes, timid forest birds builded close his powerhouses, often in the very trees under which his hammock swung.

Bob passed the Shrike corner on the way between two wells, and he told me of the enterprise in the apple-tree. There was no other tree close. Four lines of old snake-fences, bearing their usual load of treasures, crept to a meeting under its friendly boughs. Abore it was a clear broad sweep of summer sky, across which birds from the woods constantly trailed in a broken line of flight to bathe or to hunt food at the river. Beneath it Stanley's sleek herd, with the beringed ears denoting beasts of high degree, chewed their cuds, switched flies and welcomed the ministrations of a large flock of Cow-birds.

Subjects were located in each of those four fields. In one, under an arch of growing wheat, I had made a study of a Lark's beautiful nest and was waiting for the young to hatch. Through the adjoining clover-field Bob and I hunted ceaselessly for the nest of a Bobolink, which strutted the rod-line, playing the down while pouring out a lilting melody that at times seemed especially improvised to mock our unarailing efforts to find his home.

It any rate the search was a delight, for the perfume of clover was heary on the air, the drowsy hum of hig bumblebees, staggering on wing with loads of gold, was a lulling sound; singing grasshoppers, beautifully coloured and striped, feasted here; satin-winged butterflies wavered over the field while the Bobolink swung on the rod-line straining his throat to produce notes sufficiently sweet to tell it all to the brooding mate we were seeking.

Once this search for the Bobolink became a terror. Early in the morning while passing the field he flew across the road in front 


\section{THE LOGGERHEAD SHRIKE}

of me with a worm in his beak, alighting in the clover. Immediately I was over the fence, watching the spot where the bird had disappeared. On reaching it I began circling around. searching for the nest. The clover had been blown down when at a height of eighteen inches so the tops had lifted making a second equal growth. I was catching handfuls of elover, lifting it straight from the roots to see if the nest were hidden beneath the parts which lay on the ground.

In doing this I uncovered, not the Bobolink's nest, but the largest snake I ever have seen in freedom. Its body was thick as my upper arm, while it coiled round and round in a big heap. its head on top. When the light and air struck it, the skin seemed to gather in rolls on its body, its eyes blinkingly opened and closed in a dazed manner while an undulating movement ran the length of it.

My horror of snakes is complete. One instant I stood as if paralyzed, gazing at it; the next I started to the Cabin, never stopping until it was reached. Later in the day I recovered my senses, enough to lead a guide to the spot, only to find a hollow of earth fifteen inches across, worn smooth and scattered with patches of snake-skin. The snake had been in the act of shedding; probably it would have remained some time as it was, so by my foolishness I missed an opportunity to take one of the greatest natural-history pictures imaginable.

One of the fields was an open meadow of short grass. A pair of cotton-tails had a burrow there which contained two normal babiesandonedwarf, a mite no larger than my thumb but two weeks old. Here, attended by the Cow-birds, the cattle grazed, while occasionally, when temptation became irresistible, they pushed down the fence to invade the clover. Then how the Bobolink danced and scolded! And how I danced and scolded when the heat ruffled the temper of the leader of the herd, until, lowering his 


\section{FRIENDS IN FEATHERS}

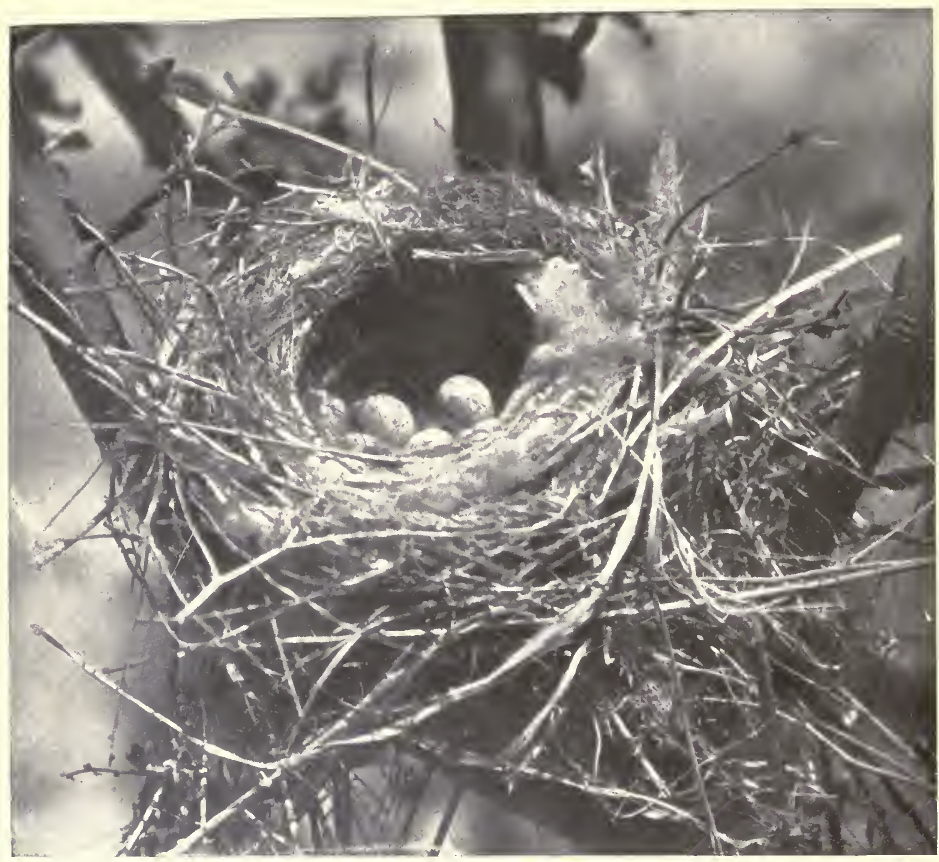

NEST AND EGGS OF SHRIKE

big head with a rumble like distant thunder, he came my way threateningly, so I had to gather my paraphernalia and hastily retreat. In the fourth field under the protecting leaf of a thistle growing near the oats, a Chewink fed four babies, not a stone's throw from the rabbit's burrow in the adjoining field.

At the central corner of these four fields grew the little scrub apple-tree in which the Shrikes located, probably because of the myriads of grasshoppers and insects within one sweep of flight, 



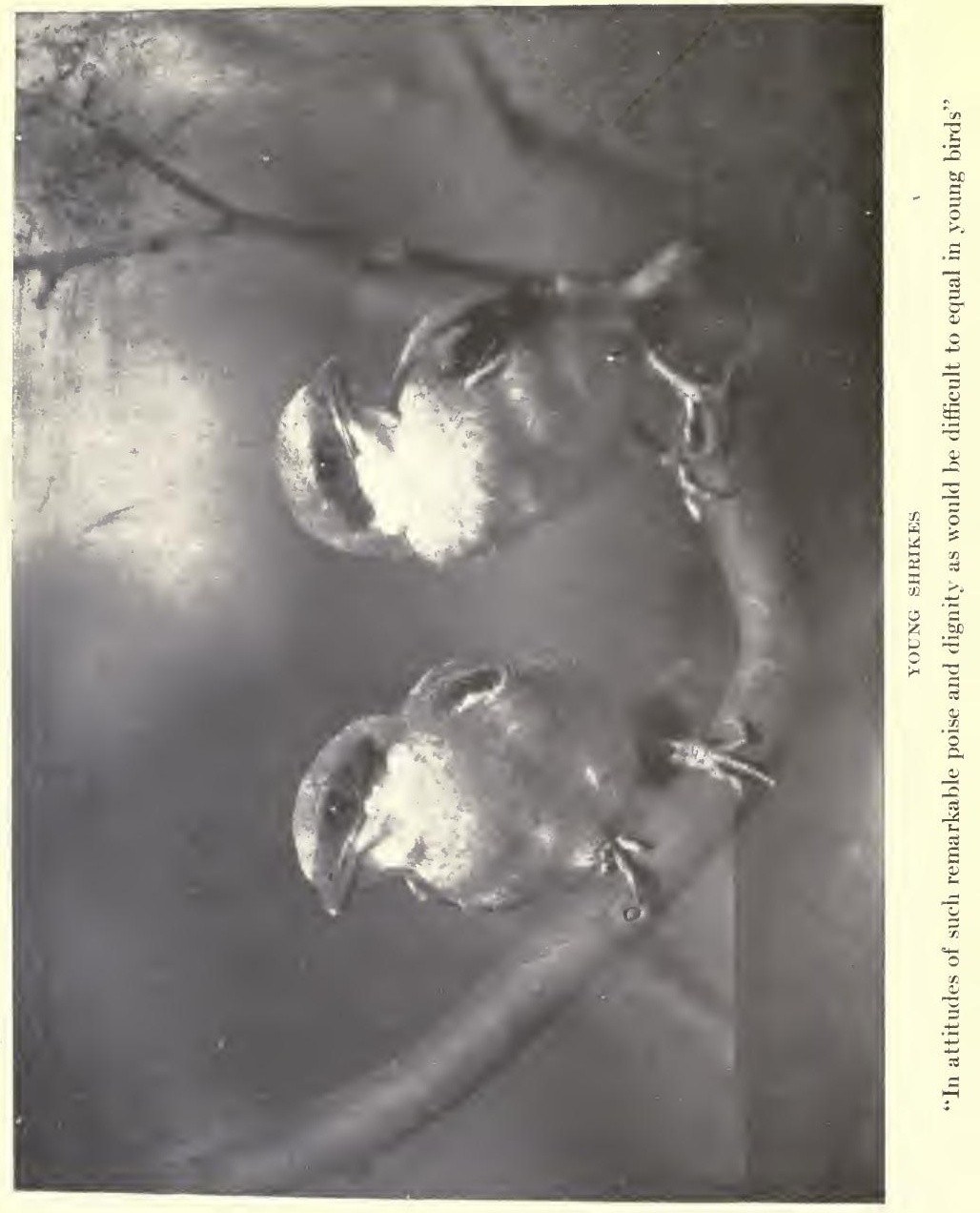




\section{THE LOGGERHEAD SHRIKE}

while it was only a short distance to wire fences decorated with wool, and the Stanley chicken yard, which furnished the lining and trimming of the nest. It was-a-larger structure than a Robin's.

Mother Shrike laid five grayish eggs, sprinkled with brownish ash. Father Shrike fed her as she brooded: "When she went to bathe he stood sentinel so no sneaking Cow-bird imposed on his family, nor did thieving Crow eat his eggs or young. Occasionally, to prove that he was more nearly related to the Vireo and the Robin than to the Hawk family, Father Shrike perched on a fence-post repeating a few notes that made the Crow laugh, drove away the Cow-birds and sent the Bobolink dancing down the rod-line chattering with every feather awry. "I have," is my answer to Maurice Thompson's poetical question as to: "Who has ever heard of such a thing as a Loggerhead Shrike that tried to sing?"

The old Shrikes were very friendly. They soon paid small heed to my work with them. But there is no place for pictures of them unless reproductions of their family run short. The young were marked exactly like their parents, also very sinilar in colour effect, while they were lovable. The grown-birds differed in having the gray parts of the feathering a solid colour, a more prominent hook on the beak, while their length of wing and tail destroyed in them the plump appearance of the babies. At a short distance no difference could be noticed except in shape.

The youngsters filled their cradle to overflowing. They were impartial, allowing Bob or me to feed them. The parts of their food they could not assimilate they regurgitated in little oblong pellets. There was no such thing as calculating the number of insects consumed in that nest in a day. The old birds kept-up a steady flight while Bob and I wearied ourselves, yet the-five squalling beaks were always wide open. If any baby failed to 


\section{FRIENDS IN FEATHERS}

receive a morsel, it caught one of its nest-mates by the bill or wing and tried to swallow it. To watch the performance made one doubt if a baby with two sound eyes could leave the nest. Father shrike might have warbled all day, but he could not have effaced the IIawk-like tendencies of his brood.

Yet it is a fact that the wildest and worst-tempered Hawk can be tamed into the most docile and obedient of pets. Young Hawks taken from a nest and raised by hand are so easily domesticated that after a few weeks of feeding they inay be released and will live on the roof of a house or among the trees, coming at call.

While in the nest the baby Shrikes squalled and fought; a few days after leaving it, when foraging for themselves, they perched in the trees and on fences of those fields, in attitudes of such remarkable poise and dignity as would be difficult to equal in young birds.

Then what beauties they were! They had plump, cunningly shaped bodies, while in the nest they were the only birds I ever have seen that could lay claim to the term "dimpled." Their feathering was extremely fine and close. Next their bodies these tiny silken feathers were white, the tips shaded to palest gray very faintly marked with black. The whole effect was of a delicate whitish gray, almost invisibly touched with black. They had jet-black dashes ruming from the corners of the mouth across the eye to the back of the ear, while the tail- and wingfeathers were white, touched with black exactly like their elders. 'They were amazingly friendly little creatures, doing such attractive things. They delighted to be fed and petted, responding to friendly advances in surprising manner.

Anyone would have liked them. I was afield for character studies. Here were birds of complex character having most peculiar tendencies. My task was to reproduce their varying moods. Their pictures shall prove if I succeeded in portraying 


\section{THE LOGGERHEAD SHRIKE}

in them the traits described. I pictured them over and over, in groups, singly and in pairs: head-pieces, tail-pieces and initials were made with them. All it required was kindness, patience and grasshoppers, to coax them into any position; but they always manifested their character. You could catch them looking very dignified, but never Dove-like.

On the whole I doubt if birdland contains more interesting and beautiful babies. Work around them was most entertaining, with the exception of the snake and the leader of the Stanley herd. It would be delightful if all birds had the Shrikes' trusting disposition and chose their beautiful and accessible locations. They furnished subjects for some of my most characteristic work with birds, while I yet can smell the clover and hear the Bobolink.

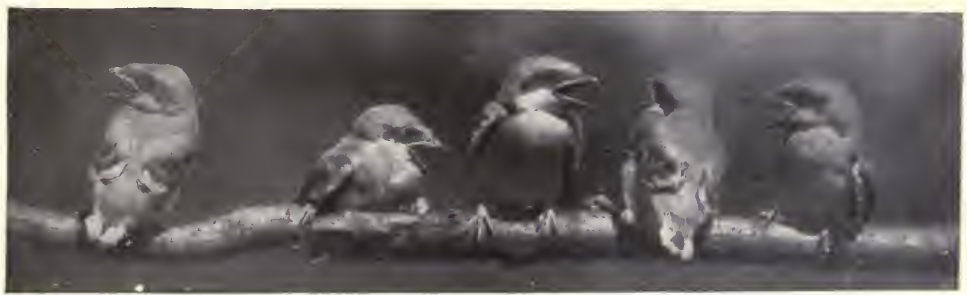

"All it required was patience and grasshoppers to coax them into any position" 
"I like

The shrike,

Because, with a thorn for a guillotine,

IIe does his work so well and clean,

A critic keen-

A practical bird,

Whose common sense

Nust be immense,

For, tell me, who has ever heard

Of such a thing

As a loggerhead shrike that tricd to sing?"

-Thompson. 



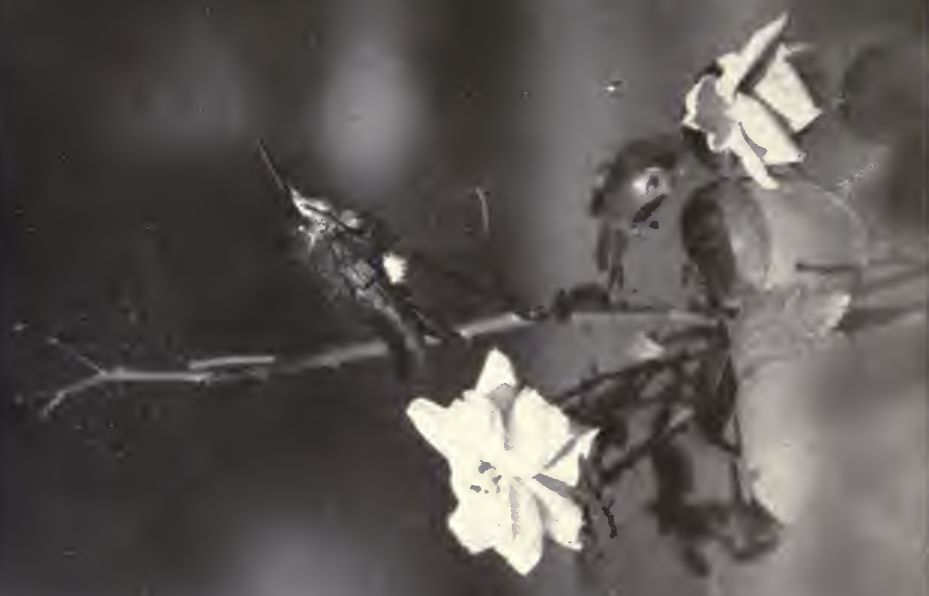

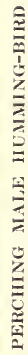




\section{CHAPTER XXIV}

\section{The Humming-bird: Trochilus Cólubris}

\section{AROUND THE CABIN}

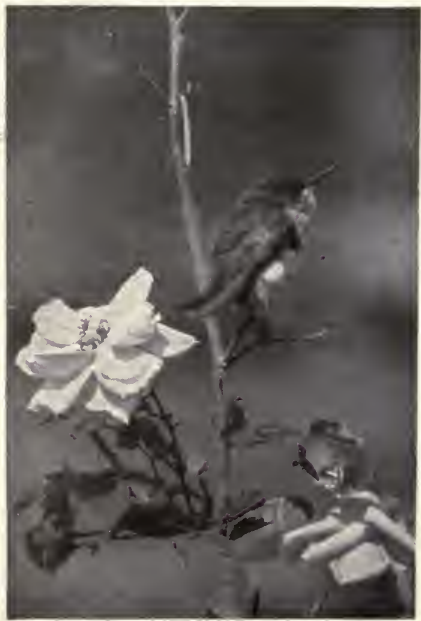

"It soon revived until it could cling to a dead twig on the bush",

When Mr. McCollum sent me word that one of his sons had located the nest of a Humming-bird, I travelled the same road I had gone over earlier in the season to the haunt of the Rail. The fact that all nature had advanced a few weeks nearer fruition made the trip none the less delightful. We found the location in deep forest in a small ironwood tree; the nest so little that only by a miracle had anyone ever seen it at all.

The tiny cradle was built of lichens lined with chestnut-coloured down fine as silk, saddled on a limb twice the thickness of a lead-pencil, and bound fast with cobwebs. $A$ silver dollar laid on top would have sheltered it perfectly during a rainstorm. There were no eggs, and as it had been discovered ten days before and the tree bent to examine it while the birds had been building, I concluded they had abandoned it. I am sure it was completed outside, but $I$ do not know that it was finished within. Because it was 


\section{FRIENIS IN FEATHERS}

the daintiest picce of bird architecture of my experience a picture was made of it eren when it was empty.

But I have had three real experiences with Humming-birds. The first, when one of them mistook the front window of the Cabin for a pool of water, and in trying to fly across it struck the glass full force and fell stunned. I heard the blow, hastened to pick up the bird, and while trying to think what could be done for it I saw that it was reviving and soon it flew away.

Whenever Molly Cotton enters the Cabin alone, simultaneously with the setting of a foot on the threshold she always sings out: "Mother!" One inflection she gives that call means: "Are you at home?" Another: "May I go to Sarah's?" And yet a third, which sends me flying at the first tone of it, means a heartbreak. This day came the trouble call, sharply defined as the alarm-cry of my Robin. Molly-Cotton stood in the doorway with big excited eyes shining from a background of flushed cheeks and flying hair. On her outstretched palm lay a rubythroated Humming-bird, both wings widely spread, but making no attempt to fly.

"Doctor it!" she demanded.

Is there anything more difficult for a mother than falling short of what her child expects of her? I did not know anything to do for a sick Humming-bird, those daintiest creatures of nectar and sunshine, but as I looked on Molly-Cotton's distressed and eager face, I knew I could not tell her so. Of course I realized there would come the inevitable hour when I would not be able to furnish "balm for every wound," but I could not fail her then, so I temporized.

"Where did you get it? Do you know what is the trouble with it?" shot.'

"I gave a boy my soda dime for it. It's hurt with a sling- 


\section{THE HUMMING-BIRI)}

"“Hurt with a sling-shot!'” I cried. "He'd better be punished instead of paid for that trick."

"But, Mother," said Molly-Cotton, "the boy who had it wasn't the boy who hurt it-that's why I bought it; and," she added with characteristic justice, "the boy who hurt it ran. He was awful sorry. He just shot. He didn't think he could ever hit it. Really, it was an accident!"

"And that is the way almost every song-bird that is shot meets its fate," I retorted angrily. "Men always must try if they can hit a thing, then when a bird as brilliant as a butterfly or a flower falls they are surprised and so sorry that it is dead. They only wanted to see if they could hit it. It is the old excuse."

Molly-Cotton advanced a step holding out the bird. "Well Mother!" she said. "Aren't you going to do something?"

"Take it into the conservatory," I answered, striving to collect my senses. First aid to an injured Humming-bird! What would it be? Of course its back was almost or quite broken, from those wide-spread motionless wings, the heary breathing and the eyes protruding with pain. From a box of abandoned nests a large one was selected with some fine twigs in the bottom, to which the bird was transferred with care.

Wounded people are always thirsty, so I proposed to give it a drink of sweetened water. Molly-Cotton ran for a teaspoon and the sugar, then we held a few drops of sweetened water to the bird's bill. At the touch of it the little creature drank and drank and ran its slender thread-like tongue over the bowl of the spoon, searching for particles of sugar. Every hour that afternoon it was given more. When Molly-Cotton came from school she carried it honeysuckle and trumpet-creeper blooms, and when either honey from the flowers or sweetened water was put against its beak it ate and drank.

I confidently expected that it would be dead by morning, 


\section{FRIENDS IN FEATHERS}

but instead it had folded its wings and before the day was over was clinging to the twigs with its feet. Then I took courage and went to work in earnest. I put it in a cool shaded place, adding hard-boiled egg thinned almost to liquid to its diet, and by the third morning it could walk and had climbed on the edge of the nest. When I saw that, "It is going to get well, sure as fate!" I cried to Molly-Cotton.

"It's going to get well! It's going to get well!" exulted the Girlie, dancing for joy.

Straightway she exacted a promise that she should be the one to open the door and give it freedom, which surely was her right. Then she thought of another world to conquer.

The night before Bob had brought me a little reddish-brown mother bat, weighted with four babies clinging to her body. I was to photograph them that day, then put them back where they had been before night. Molly-Cotton thought the bat should be fed also. She argued that if the bat had been free the night before, her mate would have fed her and with those four babies to care for she must be almost famished. So I was called upon, in all confidence, to tell what bats ate.

I told her we could not get for a bat, in daytime, what it found on wing at night, but I thought it could do no possible hurt, so I suggested fresh, warm milk. Molly-Cotton took a nickel from her purse and sped to a neighbour's for milk, while I whittled out a tiny wooden paddle. We dipped this into the milk and held it to the bat's nose. She instantly seized it between her sharp little teeth sucking and gnawing at it. She would not let go, so we took the Humming-bird's spoon and dropped milk a drop at a time on the paddle. That bat turned up her head and drank and drank like a famished creature.

We had a splendid chance to study her face. It was shaped like a young pig's, only flatter. She had a small, round, flat 


\section{THE HUMMING-BIRD}

nose like a pig's, a face very similar, and ears round like a mouse's, instead of pointed. Her fur was silken fine and of beautiful colour. Each of the four babies was a miniature of the mother. When she was quite satisfied she let go the paddle and went to sleep. Until her picture was taken and she was returned to freedom, Molly-Cotton fed her milk, which she took eagerly at every offering.

When we were congratulating ourselves that the Hummingbird was saved, came disaster. I do not know why I was so thoughtless. Its ability to climb to the edge of the nest should have warned me. The bird tried its first flight, but fell from the shelf on which the nest was placed, five feet to the cement floor and died in a few seconds.

Our next Humming-bird experience was short. I met Mr. Hale on the way to the post-office. "Hold fast all I give you," he said, reaching out a hand. What I got was a Humming-bird lying on its back, its eyes closed, its feet drawn up among its feathers, seemingly dead.

"Found that among the sweet peas this morning," he said. "It forgot to migrate and took a chill." It was October and the night had been heavy with frost.

I cupped both hands around the bird and on reaching the Cabin could see that it was alive. I gradually warmed it until it opened its eyes. Then I told Molly-Cotton to bring me four grains (granules) of granulated sugar, with one drop of tincture of ginger and five of water added to them. We held this mixture to the bird's bill and it drank feebly. In a short time it began to ruffle its feathers and shiver.

Then I sent Molly-Cotton to carry my camera to the south side of the Cabin, where she had a La France rose bush in full bloom that we had covered during the night. I followed with the bird. It soon revived until it could cling to a dead twig on 


\section{FRIENISA IN FEATIIERS}

the bush, though its tail was tucked, its feathers ruffled and it appeared chilly. We were rumning no risks, so we took its picture. I should have taken the írst one while it lay on its back, to all appearances a dead bird, but I did not think of it until too late.

I put in a new plate, then when all was ready Molly-Cotton gave the bird another drink, a big generous one. The air was rapidly warming with the rising sun and the bird now revived to the point of feeling dishevelled, for it ruffled its feathers, shook them and laid them so they looked rery sleek. The little thing felt spruce indeed, considering a few moments before, so I made a second exposure. While I was hurrying to change a plate for a third, the bird hopped to a twig above it, gave its tail and wings a flirt then with a whizz darted over the nearest trees and in a bee-line, as far as we could follow him, sailed toward the South.

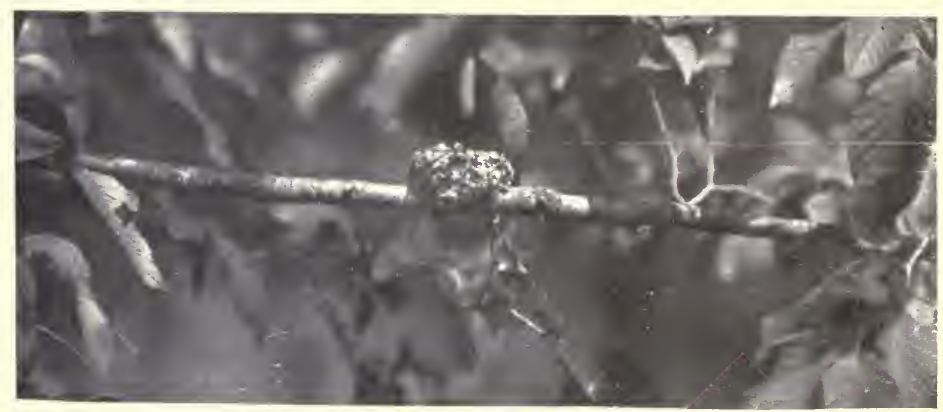

THE NEST OF A HUMMING-BIRD 



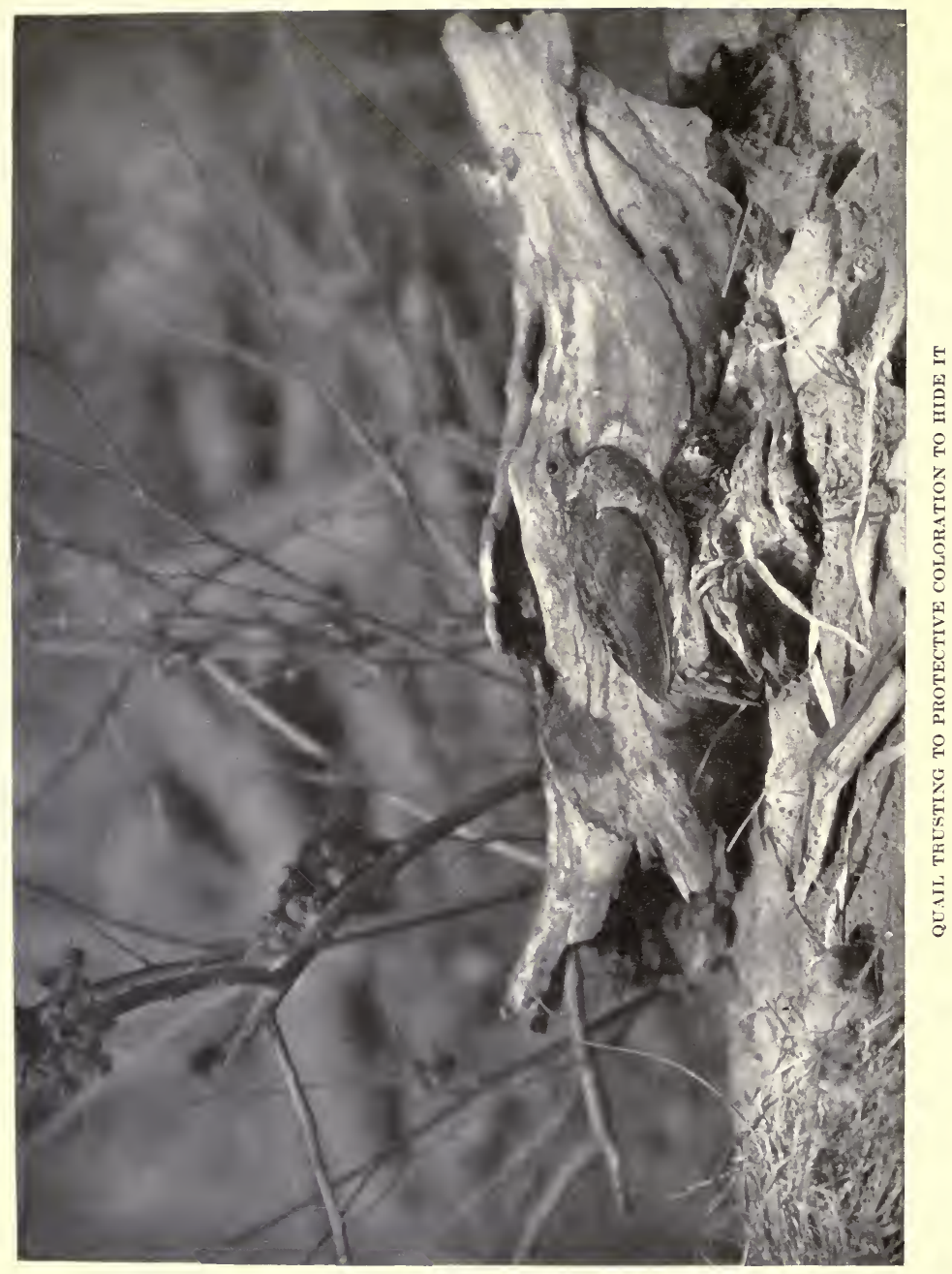




\section{CHAPTER XXV}

The Quail: Colinus Virginiámus

\section{ON THE GROUND}

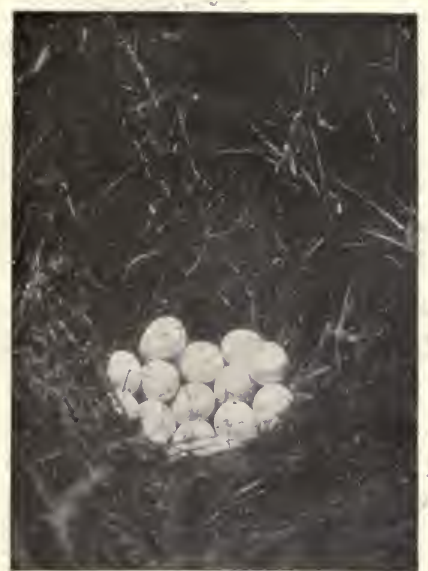

NEST OF QUAIL

Containing seventeen eggs

Wiтн the combined meadows, wheat fields and orchards of the Stanley and Aspy farms, as well as a mile-stretch of grassy river-bank from which to choose, Mrs. Bob Whitepaid Mr. Bob Black the compliment of coming within a rod of his engine-house, two yards from his foot-path to select her building site. When Bob pointed out the nest to me I was amazed.

The churning of the big engine that furnished power to pump many_wells, some of them half a mile away, shook the earth under her location. The exhaust pipe shrieked until close it the explosions were deafening. All day long the rod-lines rattled while steady streams of oil poured into the big tanks. Bob, with pointer always to heel, passed over the path many times a day. I traversed it daily, while there was a steady flow of children's feet rushing to the river to play and back to Bob to borrow fishlines, corks, hooks, knives-anything a boy could use beside the water. 


\section{FRIENDS IN FEATHERS}

There came the Quail to brood. I wonder why. Did she like company? Did she prefer to keep house where she could hear sounds and see people? Had she lingered around the place until she had lost all fear of it and hoped in the noise and proximity to humanity to find protection from her natural enemies, the snake, boy, squirrel and $\mathrm{O}_{w 1}$ ?

Bob never knew the bird was there until Gypsy made a point at her, then she was brooding on serenteen eggs. The nest was constructed on the ground. The builder had slipped through the long laair-like grasses until she found a slight depression sheltered by a small spray of wild grape-vine. There she sat down and turned around until she worked out a flat bowl-shaped place, from which she picked away the blades of green grass, using the dead ones for lining. The taller grasses closed over her while the grape-rine screened her from the sight of the man, but not from the scent of the dog.

Her nest was beautiful. I like to think she built it there because she had placed herself under Bob's protection. This idea of shy wood-things creeping to him, because they knew he was their friend and champion, makes me proud that he is my friend also. Those seventeen eggs were freshly laid, bluish white and sharply pointed at one end. The picture they made was a novelty on account of their number.

After we had secured a fair study of the nest we waited for the young. We knew our ornithology well enough to be a ware that there was small hope of reproducing them, for a Quail lays all her eggs before she begins to brood, so that the young emerge at once and travel before their down is quite dry. While we waited for these nestlings I had rare luck in securing two good studies of grown Quail in the Limberlost, so I did not bother these old ones.

We did not know how many of the twenty-three days of 330 


\section{THE QUAIL}

incubation had passed before Gypsy found the nest, but when we thought the time for the brood to emerge was close I was on hand and ready. A three-days' wait made me careless; the following day I did not reach the lease until nine o'clock. The tailpiece of this chapter shows what I had for my trouble. Not much, you think?

That one little picture helps to settle two questions long in dispute concerning the Quail. Many writers contend that young Quail remain in the nest some time after they emerge. They go before they are thoroughly dry and feed themselves from the start. The proud father, with head feathers flared to a crest and hackle bristling, leads the way, the young follow, the mother brings up the rear. When either old bird sights a morsel fit for the young to eat it calls the chicks to come and with its bill indicates what is to be eaten, often breaking the food up so that as many as possible shall get a bite. The young had left this nest so soon after hatching that the shells were warm, while flies and ants were gathering over them, attracted by tiny fresh blood vessels in the lining.

Also these shells seemed to prove that the mother had gone over each egg at time for emergence and with her sharp, strong bill cut the shell and lining in halves, releasing the young. I had been contradicted so frequently on this statement that I had quit making it, until this nest of shells was found. They clearly show that the work is done from the outside, as a deep rim is bent $i n$, the lining cut instead of torn, and each shell divided exactly in halves.

There was pleasure in proving this point long defended, but I bewailed those babies. So to comfort me Bob said we would search beside the river and perhaps we could find them. Neither of us had much hope, but there were so many other things to find we were sure not to waste time, so we started. We did find things, 


\section{FRIENDS IN FEATHERS}

for all nature was very busy that morning. We took a rare butterfly, located a Cuckoo nest, a Woodpecker tree, a Song sparrow's bush, and found a fine specimen of cardinal flower, which is not common in this locality.

On the way back to the carriage, from under our very feet Mother Quail arose with a whirr, while there was a breath of faint peeps. We were in the midst of the seventeen youngsters. I dropped to my knees and began combing the grass with my fingers. The first sweep brought up a tiny ball of fluff with a black striped back, the second another. By that time Bob had one, then I had another; my hands were full of Quail now and no place to put them. Bob came with a second chick so what to do with them was a serious problem, for their little legs flew.

Then Bob sighted another baby and in desperation stuffed the two he held into the front of hisflannel shirt. I handed over mine and in they went also. Then we hunted Quail by hand. The sun was hot and it was warm work, but we had eight before we quit; that was all we felt we could manage at once. What to do with them became the next question.

The grass was high, so there was no chance where we were. I suggested taking them back to the nest. But that was in high grass also. Bob had a better plan. He knew where there had been a Quail-nest in an adjoining wheat field, beside a big stone. We could have a better opportunity there, and one egg remained in the nest. Also it was close the carriage and would save moving the cameras far, so I welcomed the suggestion.

I set up the camera, focussed on the nest, bent back the wheat, left the unhatched egg as it lay, and announced I was ready. Bob produced the Quail. I held them until he found all of them and then we placed them in the nest. Over the stone and into the wheat they darted like weasels. Two were lost completely be- 


\section{THE QUAIL}

fore we knew it. Again and again we tried, but there was not the slightest chance to make an exposure, for our hands would have been the whole picture. At last we were worn out completely. We had only three of our birds left. We carefully put them down in the nest, Bob on one side, I on the other; he holding the babies, I ready to squeeze the bulb or stop a young one if it ran my way.

"Now let me try," I said.

Bob lifted his hands. Over the stone toward the wheat raced the birds. I knew that all of them were on the stone when I snapped. Development of the plate proved that Bob had thrust out his hand to stop them, so I had taken it also, although the motion was so quick that neither of us knew it. We both were worn out and made no attempt to try again. I was accustomed to being warm, tired, wet and muddy, but a vague unusual discomfort was stealing over me as I slipped the slide in the holder and packed the camera. What ailed me! I actually was in distress. I glanced at Bob. His face and arms were like red flannel. Was he suffering, too? He did not seem happy. I had a right to sacrifice myself for my work if I chose, but I had no right to punish Bob. I studied him closer.

A million tiny red lice were swarming up his neck and over his face and arms. Only a quarter of a million fell to my share but they drove me frantic. I climbed into the carriage and almost killed Patience racing to the Cabin. Glancing back I saw Bob come from the power-house with a bundle and run faster than the pointer toward the river. I stopped in passing that afternoon to see if he were alive, to find him smoking his pipe in a hammock on the river-bank. He said in fifteen minutes after I left, the old Quail were busy whistling and calling until they collected their entire brood. 


\section{FRIENDS IN FEATIIERS}

I was sorry to have missed that. I think a Quail call, the Bob White whistle, beautiful. It is mellow, musical, inflected to a nicety, and it is always so cheerful and happy. I like Quail love-making, too; those soft, tender faint wisps of sound, those cheeps and peeps and gently-murmured things. In fact, the only note a Quail makes which I do not like is his alarm-cry, and I dislike to hear that from any bird.

I am sorry our legislators do not put Quail among song birds. Their plumage is much handsomer than some of our choicest singers; they are graceful and elegant on foot, while their music every one knows and loves. Only a note shorter and only a degree less melodious than the Lark, which is of finer flavour as food; yet the soul sickens at the thought of such sacrilege in the (ase of the Lark-why not the Quail also?*

I love these two birds which I always think of together. They use the breast of earth in common in the business of living. The notes of their songs are syllabicated the clearest and enunciated the purest of any of our singers. But the Lark is the bird of Heaven, the Quail is of the very earth. Soaring on wing the Lark seems to catch the breath of divine inspiration in his note that enthralls and uplifts the spirit. Keeping close to the dark earth, the Quail draws from it strength and courage, which so tincture his tones as to renew hope and cheer in our tired hearts and set them singing with him.

"Bob, Bob White! Bob, Bob White!" How beautifully it pipes up from meadow-grass and clover! How it softens and quivers with the passion of mating! How it swells and rings when flung as a challenge to a rival from stumps and fences! How it comes sweeping in certain, steady tones on the breast of the river! What would summer be to lovers of field and stream without it? How little children everywhere love and try to

*'The Ohio Legislature of 1917 has just placed Quail among song birds. 


\section{THE QUAIL}

imitate it! Sip nectar of fruit and honey of flower that you may trill even sweeter, $\mathrm{O}$ ye favourites of protecting fortune, or soon this plucky little gamester of the fields will win enough hearts with his cheery whistle to place himself among you!

Gene Stratton-Ponter.

Limberlost Cabin, March 17, 1906.

Revised, $191 \%$.

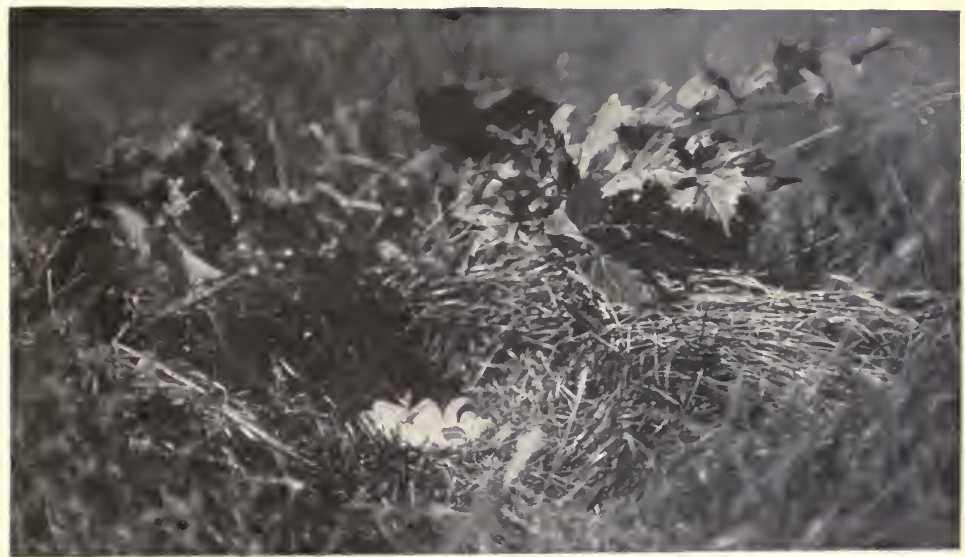

Proof that Mother Quail cuts the shells of her eggs in halves and releases all her young at one time 


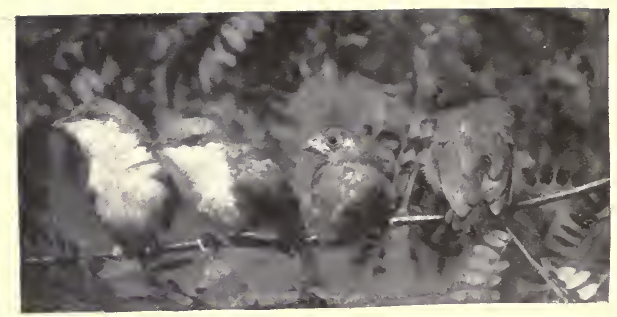




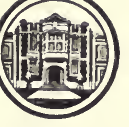

THE COUNTRY LIFE PRESS

GARDEN CITY, N. Y. 
(24) 6 





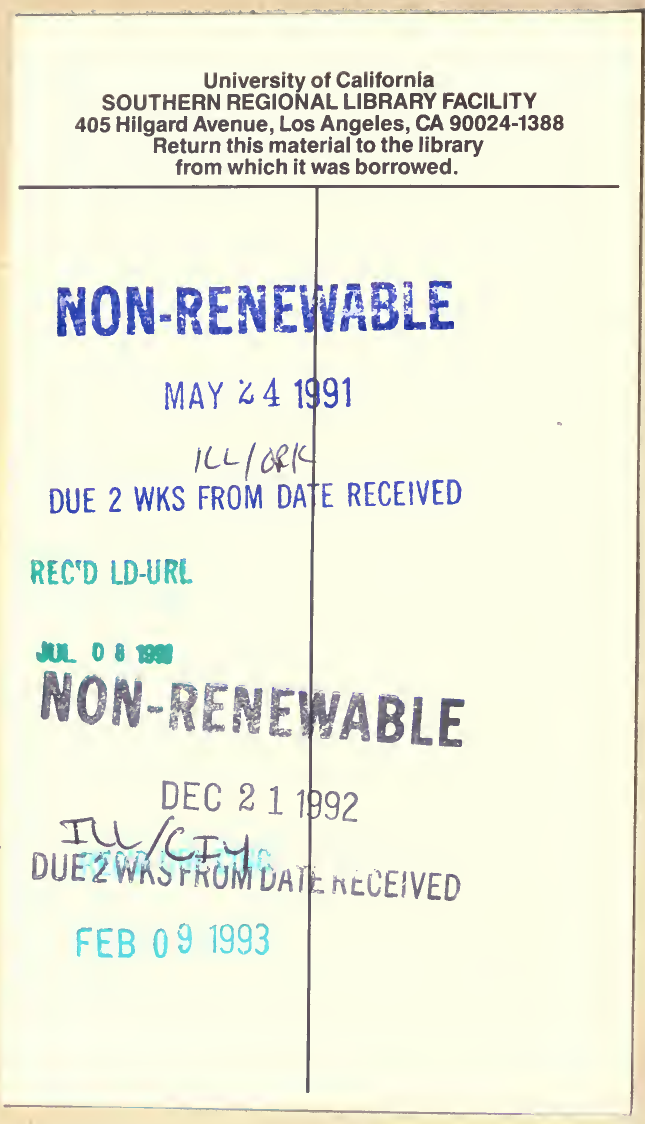



UNIVERSITY OF CALIFORNIA, LIBRARY, LOS ANGELES, GALIF. 
